ERDÉLYI TUDOMÁNYOS FÜZETEK

$$
281
$$

\author{
BENŐ ATTILA
}

\title{
KONTAKTUSJELENSÉGEK \\ AZ ERDÉLYI MAGYAR \\ NYELVVÁLTOZATOKBAN
}

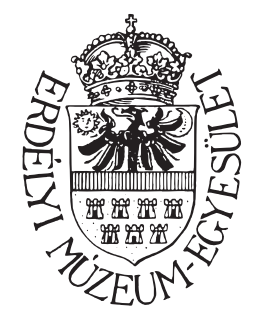

Kolozsvár, 2014 
A kötet megjelenését a Communitas Alapítvány, Bethlen Gábor Alap és a Magyar Tudományos Akadémia támogatta.

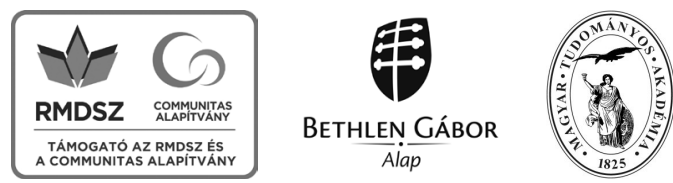
(C) Benő Attila, 2014
(C) Erdélyi Múzeum-Egyesület, 2014

\section{Felelős kiadó}

BIRÓ ANNAMÁRIA

\section{Lektorálta}

Dr. ZELLINGER ERZSÉBET, ny. egyetemi docens (ELTE)

Dr. NAGY LEVENTE, egyetemi docens (ELTE)

\section{Korrektúra}

ANDRÁS ZSELYKE

Mứszaki szerkesztés, borítóterv

BODÓ ZALÁN

Nyomdai munkálatok

GLORIA, Kolozsvár

Felelős vezető

NAGY PÉTER

Descrierea CIP a Bibliotecii Naţionale a României BENÓ, ATTILA

Kontaktusjelenségek az erdély magyar nyelvváltozatokban / Benő Attila. - Cluj-Napoca : Societatea Muzeului Ardelean, 2014

Bibliogr.

Index

ISBN 978-606-739-004-9

811.511 .141 


\section{TARTALOM}

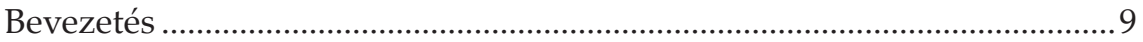

I. A román-magyar nyelvi érintkezés kutatástörténete ................................11

II. A romániai magyar nyelvváltozat szociolingvisztikai helyzetének összegző bemutatása, különös tekintettel a demográfia, az oktatás és a nyelvi jogok kérdésére 21

1. Az érintkező nyelvi közösségek státusa és demográfiai adatai.......22

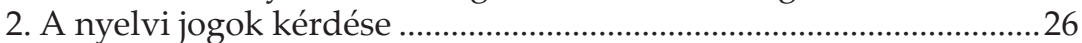

III. A kontaktusjelenségek tipológiája ...............................................................33

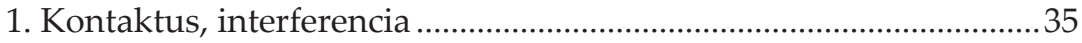

2. Az interferencia és a kölcsönzés társadalmi és nyelvi kontextusa.. 35

3. Idegen szó, kölcsönszó, jövevényszó .................................................37

4. A kontaktusjelenségek tipológiája .........................................................39

4.1. A közvetlen (direkt) kölcsönzés formái .....................................40

4.1.1. Tulajdonképpeni vagy morfémakölcsönzés ....................40

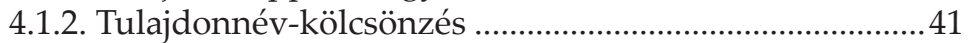

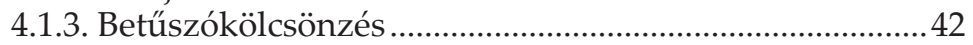

4.1.4. A hangalakkölcsönzés......................................................... 42

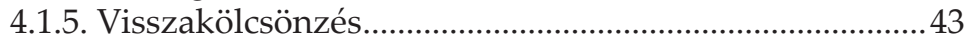

4.2. A közvetett (indirekt) kölcsönzés és nyelvi hatás formái ........43

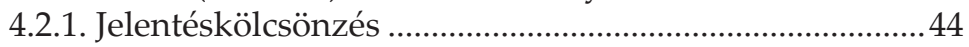

4.2.2. Tükörszavak, tükörkifejezések ..........................................4 44

4.2.3. Közvetett frazémakölcsönzések, vándorszólások,

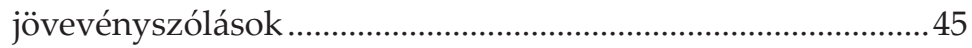

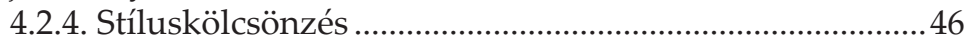

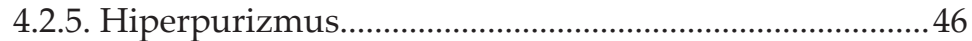

4.2.6. Relatív kontaktusjelenségek..............................................4 47

4.3. Hibrid kölcsönszavak és hibrid szerkezetek .............................49 
IV. Közvetlen (direkt) kölcsönzések 51

1. Közvetlen kölcsönzések a nyelvváltozatok, regiszterek szempontjából. .52

2. Köznévi kölcsönzések a stílusváltozat és az érzelmi viszonyulás szempontjából .58

3. Tulajdonnév-kölcsönzés, betűszók átvétele .......................................63

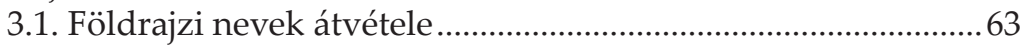

3.2. Személynevek (családnevek) meghonosodása ..........................66

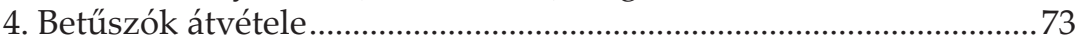

5. Hangalakkölcsönzés, kölcsönhomonímia, visszakölcsönzés ...........75

V. Közvetett (indirekt) kölcsönzések ..............................................................79

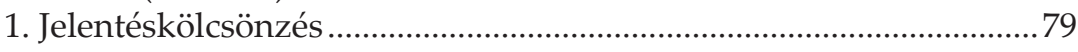

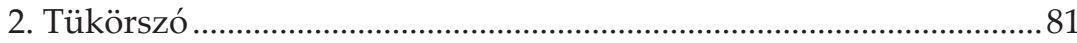

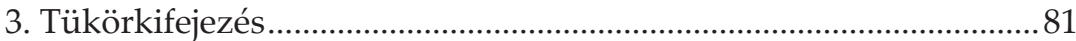

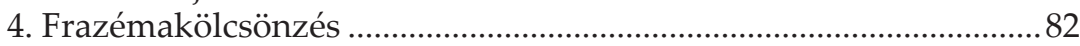

5. A közvetett átvételek és a nyelvváltozatok összefüggése ..................82

6. A tükörszerkezetek formális-szerkezeti sajátosságai............................86

7. Tükörszerkezet vagy megőrzött régiség? ............................................. 87

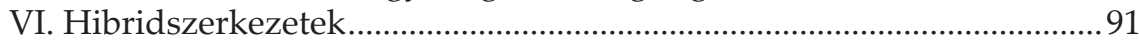

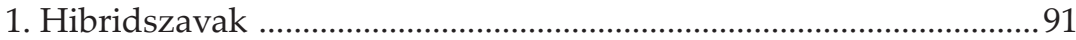

2. Hibridszerkezetek …………………......................................................93

VII. A lexikai elemek meghonosodásának alaktani kérdései.

A másodlagos, harmadlagos kölcsönelemek kialakulása ..............................95

1. Az átvevő nyelv morfológiai rendszerének hatása a kölcsönelemek meghonosodására .........................................................95

1.1. Népetimológia és belehallás ......................................................96

1.2. Szóelvonás és integrálódás .......................................................98

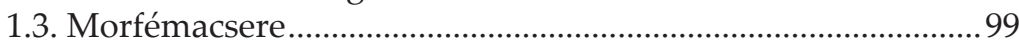

2. Másodlagos, harmadlagos kölcsönelemek kialakulása.

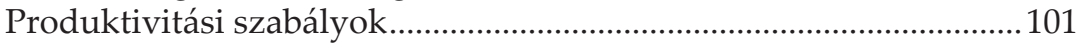

2.1. Igei átvételek alaktani integrálódása ..........................................101

2.2. Névszói átvételek alaktani integrálódása ................................106

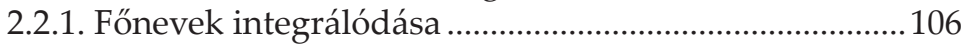

2.2.2. Melléknevek integrálódása ..............................................109

VIII. Jelentésváltozási tendenciák................................................................111

1. A jelentésmódosulás forrása ..........................................................112

2. Specifikus jelentések kialakulása .........................................................113

3. Jelentésbővülés az átadó nyelv hatására...........................................115

4. Metonimikus jelentéseltérések ......................................................117

5. Generalizálás: elvontabb jelentések kialakulása..................................118

6. Értékjelentés-módosulás ...................................................................119 
7. Nagyobb mértékben eltérő jelentésviszonyok ...................................119

8. Alakváltozatok és jelentéskülönbségek .............................................120

IX. Mondattani kérdések ............................................................................123

1. Szórendi jelenségek ..........................................................................123

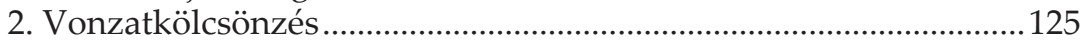

3. Kontaktusjelenségek az alany és az állítmány szintjén ....................126

4. Számbeli egyeztetési jelenségek ......................................................128

5. Kontaktusjelenségek a tagmondatok határán...................................130

X. Összegzés, következetetések .................................................................133

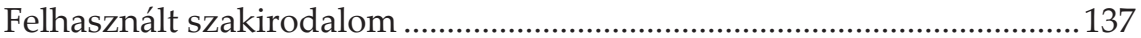

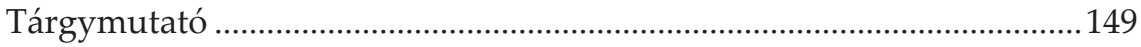

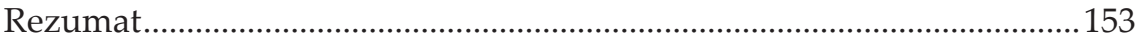

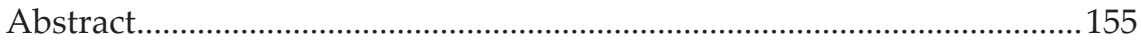





\section{BEVEZETÉS}

Ebben a könyvben az erdélyi magyar nyelvváltozatok kontaktusjelenségeit és azok szociolingvisztikai hátterét ismertetem monografikus jelleggel. ${ }^{1}$ Egyrészt az eddigi kontaktusvizsgálat eredményeit összegzem, másrészt újabb empirikus adatok alapján közvetlen (direkt), közvetett (indirekt) és a hibrid kölcsönzések formáit mutatom be, különös tekintettel a meghonosodás folyamataira. Mivel Erdélyben az államnyelv, a román gyakorol a legerősebb hatást az erdélyi magyar nyelvváltozatra, elsősorban a román nyelvi hatást vizsgálom strukturális szempontból, azaz nemcsak lexikai, hanem morfológiai, szemantikai és szintaktikai jelenségeket is elemzek. Ugyanakkor több helyen az angol nyelv hatására is utalok, lévén, hogy újabban bizonyos nyelvváltozatokban (a szaknyelvekben, a szlengben, az informális internetes közlésben) erőteljes angol eredetű kontaktusjelenségeket figyelhetünk meg.

A vizsgálatok korábbi ismert forrásai mellett (Bakos 1982, MártonPéntek-Vöő 1977, Zsemlyei 1979) felhasználom az újabb keletű adatbázisokat is, mint amilyen a Termini magyar nyelvi szótár és adatbázis (ht.nytud. hu/htonline), a kolozsvári egyetem Magyar és Általános Nyelvészeti Tanszékén a témakörben íródott mesteri és doktori értekezéseket (pl. Magyari 2010, Sorbán 2011, Homonai 2014), valamint a 2009-ben a kolozsvári Nemzeti Kisebbségkutató Intézet (ispmn.gov.ro/hu/) reprezentatív mintavétellel végzett felmérésének (Demográfia, rétegződés, nyelvhasználat) eredménye-

\footnotetext{
${ }^{1}$ Az erdélyi magyar nyelvoáltozatok kifejezésben az erdélyi minősítés nem a történelmi, belső Erdélyre vonatkozik, hanem a Kárpát-medencei magyar nyelvterület Romániához tartozó részét jelöli a Partiummal, Szatmár, Máramaros régióval és a Bánsággal együtt. A kifejezésben szereplő többes szám azt jelzi, hogy ez a regionális nyelvváltozat is összetett, nyelvjárások (dialektusok), csoportnyelvek (szociolektusok) és a regionális köznyelv együttes hatásaként adott.
} 
it. ${ }^{2}$ Ugyanakkor felhasználtam a korábbi és újabb kutatások alapján általam összeállított román eredetű családnevek adatbázisát is (Benő 2011c).

2000-ben megvédett doktori értekezésemben (Benő 2004) a román hatás szemantikai kérdéseit vizsgáltam, és ebben a munkámban a vizsgálat körét kiterjesztem a kontaktusjelenségek valamennyi típusára. Ennek a vizsgálatnak egyfajta általános kontaktológiai megalapozását jelentette a Kontaktológia című egyetemi jegyzetem, amely földrajzilag és tipológiailag változatos nyelvi kontaktusokat mutat be a nemzetközi és a magyar szakirodalom, valamint a saját kutatásom alapján (Benő 2008).

Ez a munka az elmúlt tizenöt év román-magyar vonatkozású kutatásait összegzi egyrészt saját kutatások, másrészt a szakirodalomban megjelent újabb eredmények felhasználásával. A kötet a kutatástörténeti összefoglaló után a romániai magyar nyelv szociolingvisztikai helyzetét mutatja be röviden, majd a nyelvi érintkezések alapfogalmait és terminusait értelmezi. A kontaktusjelenségek megnyilvánulását a különböző nyelvi szinteken ismerteti az alaktani és lexikológiai jelenségektől a mondatszerkezeti hatásokig. A vizsgálat a kontaktusfolyamatokat kiterjeszti a tulajdonnevek (földrajzi nevek, családnevek) vizsgálatára is, mivel a nyelvi érintkezések ezen a területen is határozottan megmutatkoznak.

${ }^{2}$ Ez a több mint 4000 erdélyi magyar adatközlőt kikérdező kutatás olyan felmérés, amelynek adatai szociológiai értelemben a lehető legnagyobb mértékben megbízhatóak. A kutatás új eredményekkel szolgál az erdélyi magyarok nyelvismeretéről, normatudatáról, a kétnyelvűségi folyamatok megítéléséről. 


\section{A ROMÁN-MAGYAR NYELVI ÉRINTKEZÉS KUTATÁSTÖRTÉNETE}

A magyar nyelvet ért román hatás kutatásának eddigi eredményeinek összegzése egyértelművé teszi, hogy az ilyen irányú kutatások a 19. század végétől napjainkig szinte folyamatosnak mondható.

A román eredetű lexikális elemekre vonatkozó első írott dokumentumok forrásértékü jelzésekként értelmezendők. Ilyen a legkorábbi, a XVI. századból fennmaradt Gyöngyösi Latin-magyar Szótártöredék is, amelynek eredetije 1538-1556 között keletkezhetett. Ebben már olyan kölcsönszavak fordulnak elő, amelyek később az erdélyi népnyelv meghonosodott elemeivé válnak: berbécs, cáp, pulyáló, szokmány (Szabó Z. 1965b). Megemlítendők még a Pápai Páriz-szótár 1708-1801 közötti kiadásainak magyar szókincsében felelhető román átvételek, valamint Gyar mathi Sámuel Vocabulariumának román eredetú kölcsönszavai (Szabó T. 1960a, 1960b). A felhalmozódó kölcsönszavak további forrásaiként tartják számon Gáspár János tájszógyüjteményét és Vas József Kapnikbánya s vidékének nyelvjárása címü tanulmányát (1863). Az előbbinél negyven, az utóbbinál harminc román származású lexémát találunk. A szótárak mellett a szépirodalom nyelvezete is jelez hasonló irányú szókészleti gazdagodást. Barcsay Ábrahám költészetét vizsgálva, Szabó Zoltán számos román átvételt mutatott ki, és jelezte ezek expresszivitásbeli értékét. (Ilyenek: batuta, ficsúr, furulya, kaliba, toka, zsendice [Szabó 1965a].)

Az első részletező, az etimológiai igényeknek megfelelő tanulmányt Edels pacher Antal írta 1876-ban. (Ez az évszám az ilyen irányú tudományos vizsgálatok kezdetét is jelenti.) Ő már 124 román eredetú lexémával számol. ${ }^{3} \mathrm{~A}$ kérdés iránti érdeklődés növekedését jelzi, hogy a következő években több tanulmány is foglalkozik a kérdéssel (Alexics György

\footnotetext{
${ }^{3}$ Szójegyzékébe olyan lexémák is bekerültek, amelyekről utólag kiderült, hogy nem román eredetủek. Ilyenek például góbé, golonc, imola, izgána, kolna, szompor (1. Bakos 1982: 478-82.)
} 
[1887] tanulmánya mellett Szarvas Gábor [1874] és Munkácsi Ber nát [1880,1881] írása említésre méltó, mivel ők azok, akik elsők között ismertetnek román vonatkozású csángó tájszavakat). Szinnyei József, felhasználva az általa szerkesztett Magyar tájszótár gazdag anyagát is, 1893-94-ben jelentette meg azt a kizárólag román hatással foglalkozó tanulmányát, amely szinte a mai napig forrásként szolgált a román eredetü elemek számbavételéhez. Ez az írás nem csupán összegzi a XIX. századi hasonló kutatásokat, de meglehetősen sok új elemet von be a vizsgálatba (340 román kölcsönszót közöl). Szinnyei az etimológiai vizsgálatokban figyelemre méltó jelentéstani szempontokat is érvényesít. Ami hiányzik mind Edelspacher, mind Szinnyei tanulmányában, az a kölcsönszók időrendi kérdéseinek tisztázása. A későbbiekben Gombocz Zoltán és Melich János Magyar etimológiai szótára volt az a mü, amely jelentős mértékben hozzájárult számos románból származónak feltételezett kölcsönszó eredetének tisztázásához. Damián István Adatok a magyar-román kölcsönhatáshoz címü tanulmányában kétszáz új kölcsönszóval gyarapítja az ismert román eredetű átvételek számát (1912). Az ő adattára még színesebbé teszi a román eredetű szókészletet. Nála már káromkodások is szerepelnek, mégpedig olyanok, amelyekben maga az átokszó lefordítatlan marad (egyen meg a csuma; vigyen el a gája; Erigy a trudába). Megjegyzendő, hogy Damián olyan etimológiai értelmezéseket is megfogalmaz, amelyek jelentéstani szempontból kifogásolhatók. Ilyen a RK-ban is közölt kecelus 'fanyelü bicska', amelyet Damián a r. 'kutyácska, kutyakölyök' jelentésü cățeluşból eredeztet. Más téves szószármaztatása: berbence, ciher, cika, difámál, pereszlen, pimpiri (Bakos 1982: 478-82).

A Trianon utáni erdélyi magyar nyelvváltozatokban tapasztalható román hatást Csüry Bálint jelzi először (1931). Ő jegyzi föl az erdélyi hivatali szókincs azon elemeit, amelyek a román adminisztráció következményeként jelennek meg az erdélyi magyar nyelvhasználatban. (A kisebbségi lét anyanyelvhasználatának funkcionális beszűkülését jelzi az, hogy mára meglehetősen szélessé terebélyesedett ez a kölcsönszóréteg.) Ebből az időszakból kiemelendő még a sokat idézett Yrjö Wichmann 1936ban megjelentett északi csángó tájszótára, amely nélkülözhetetlen forrása minden további csángó nyelvi kutatásnak.

A kérdés első, valóban monografikus értékű feldolgozása Blédy Gézána k köszönhető (1942). Ố az első kutató, aki az adatgyűjtésen túl (583 kölcsönelemet sorol fel) az elméleti feldolgozáshoz is hozzákezdett, és a saját szempontjai szerint el is végezte. Érdeme, hogy a beilleszkedéssel járó fonetikai, morfológiai és szemantikai szabályszerüségeket fogalmaz meg. Ez a felsorolás egyben a kidolgozottság mértékét is jelöli: a fonetikai rész analitikusabb, a szemantikai pedig vázlatszerünek tünik, bár olyan 
fontos jelenségekre figyel föl, mint a jelentésszúkülés, román specifikumra való utalás, jelentésfejlődés, szófajváltás. Ezeknek a megnyilvánulási módjait, esetleges eltéréseket nem részletezi, csupán adatokat sorol fel a megnevezett jelenség illusztrálására, így nem derül fény a megnevezett folyamatok belső árnyaltságára. Alaktani utalásaiban többek között a népetimológia körébe sorolható jelenségeket is említ (ilyenek például a szóvégi $-t$, illetve $-k$ hangok grammatikai morfémaként való értelmezése). Az elemzés értékét növeli, hogy a szerző nemcsak az addig felhalmozott ilyen vonatkozású tájnyelvi anyagot hasznosítja, hanem a korabeli erdélyi magyar sajtónyelvben is kimutatja a román eredetü lexémákat. (Igaz, számos a magyarban elerjedtnek tekinthető idegen szót is román hatásként értelmez, akkor is, ha a szó fonémaszerkezetében semmi se utal erre - ilyen például az abszolút, aktuális, emigrál, funkcionál, szociális, tradíció stb.). Sajnos Blédy a történeti szempontot sem érvényesíti kellő pontossággal abban az értelemben, hogy a kölcsönelemek első előfordulási időpontját nem jelöli meg év szerint, csak a századra utal. Ha figyelembe vesszük azt, hogy előtte még ez nagyvonalú korszakolás sem történt meg, akkor ezt is érdemeként kell elkönyvelnünk. Az értekezés továbbá fontos adatokat közöl arról, hogy a szóban forgó román lexéma milyen más nyelvekbe került át. Így például több helyen jelzi, hogy számos kölcsönelem az erdélyi szászok nyelvében is megtalálható (ilyen például a csobán 'juhász', csokán 'kalapács', prapagyit 'ügyetlen', pupuza 'búbos banka', tekelósz 'gyenge (ember)', tenzsikál 'ímmel-ámmal eszik'), de utal a szó bolgárok vagy ukránok általi kölcsönzésére is. Ezek az adatok a nyelvek közötti kölcsönhatás szempontjából rendkívül értékesek, és ilyen vonatkozásban Blédy műve egyedülálló a magyar-román nyelvi érintkezésre vonatkozó szakirodalomban.

A második világháború után egyrészt nagyobb mértékben előtérbe kerül a kölcsönszókincs történetiségének a kérdése, másrészt az adatgyuujtő munkák rendkívüli módon megszaporodnak. Nem véletlen, hogy elsőként két nyelvtörténeti munka szerzőjét kell említenem. Az egyik Kniezsa István, a másik pedig Bárczi Géza. Kniezsa a szláv jövevényszavak vizsgálatában elkülönítette a nem szláv eredetű szavakat, és ezek közül egyesekről kimutatta a román eredetet (Kniezsa 1955). Ilyen szempontból is haszonnal forgatható Kniezsa István főművének tekinthető monográfia (Vö. Szabó T. 1967). Bárczi Géza érdeme, hogy A magyar szókincs eredete (1958) című művében elsőként végezte el a román eredetű kölcsönszókészlet korszakolását.

1958-ban a kolozsvári egyetem magyar tanszékén Szabó T. Attila és Már ton Gyula vezetésével két kutatócsoport alakult, amely célul tüzte ki a román nyelvi hatás széleskörű, elmélyült vizsgálatát. A két kutató külön tanulmányban foglalkozott a magyar nyelvet ért román hatás addi- 
gi eredményeivel, hiányosságaival, és egyben erre a területre vonatkozó újabb célokat is megfogalmaztak: minél gazdagabb adatanyag feltárását, számbavételét és módszeres feldolgozását (Márton 1959: 35-39, Szabó T. 1962). Szabó T. Attila és munkatársai (B. Gergely Piroska, Kósa Ferenc, Szabó Zoltán, Vámszer Márta, Zsemlyei János) diakrón vizsgálatot folytattak: összegyüjtötték és rendszerezték a kezdetektől a 19. századig terjedő kölcsönszóanyagot. Ennek a munkának az eredménye $A$ magyar nyelv feudalizmuskori román elemei (FeudRomKsz) címü monográfia. ${ }^{4}$ A mú 840 kölcsönszót elemez egykori dokumentumok alapján. Ennek köszönhetően ma már meglehetősen pontos képünk van arról, hogy a különböző átvételek mikor kerülhettek be a magyar szókincsbe. A szócikkek tanulsága szerint a vizsgált korszakban a román kölcsönszavak még nagymértékben megőrizték az eredeti jelentésüket, és csak rendkívül szórványosan fordul elő jelentésmódosulás (pl. a kaláka esetében). Márton Gyula munkatársaival együtt (Péntek János, Vöő István) szinkrón kutatásokat végzett, különös tekintettel a nyelvjárások román kölcsönszavaira. A célok között szerepelt a román hatás nyelvjárások szerinti feltérképezése, a legújabb román kölcsönelemek összegyüjtése és a beilleszkedés hangtani, alaktani és jelentéstani vizsgálata. A 60-as években ilyen irányban is intenzív adatgyűjtések folytak. A román hatás szempontjából Balog h Öd ön a gyimesi csángó, Már ton Gyula a moldvai csángó tájszavakat vizsgálta, Murádin László az aranyosszéki nyelvjárást, Zsemlyei János pedig a Kis-Szamos vidéki tájszólást kutatta (Balogh 1961, Murádin 1960). Ennek a búvárkodásnak köszönhető két önálló kötet megjelenése. Az egyik Márton Gyula 1972-ben megjelent múve (A moldovai csángó nyelvjárás román kölcsönszavai), a másik Zsemlyei János 1979-ben kiadott doktori értekezése. Ezek a munkák az adatok szempontjából a $A$ magyar nyelvjárások román kölcsönszavai (RK) című monográfia előzményei, de a kutatási eredmények vonatkozásában minden további román-magyar nyelvi érintkezés elemzésnek kiindulópontjai lehetnek, ezért a következőkben részletesebben tárgyalom őket.

Márton Gyula a moldvai magyar nyelvjárást ért román nyelvi hatás elemző könyvében hangtani, alaktani, szókészlettani és jelentéstani jelenségeket ismertet. A jelentéstani kérdések némileg háttérbe szorultak a hangtani, alaktani vizsgálatokhoz képest. Jó lett volna, ha a szerző nagyobb mértékben hasznosítja korábbi, jelentéstani vonatkozású tanulmányait (Márton 1958, 1960). Igy például nem említi, hogy egy-egy magyar lexéma denotatív értékét miként módosíthatja a párjának tekintett román nyelvbeli poliszém alak jelentésstruktúrája, jóllehet az 1960-as tanulmá-

\footnotetext{
${ }^{4}$ A mű kézirat formában tanulmányozható a kolozsvári egyetem Magyar és Általános Nyelvészeti Tanszékén.
} 
nyában részletesen foglalkozik a kérdéssel. A könyv jelentéstani része a következő kérdéseket érinti: a kölcsönszó eredeti jelentésében való meghonosodása, jelentéshasználati ingadozás, alkalmi jelentésváltozás, jelentésfejlődés és jelentésmegoszlás. Márton Gyula nem tárgyalja részletesen a jelhasználati ingadozást és az alkalmi jelentésváltozást, mivel ezek szerinte a román nyelv jobb ismeretével megszűnhetnek. Ez részben igaz, de számos meghonosodott kölcsönszó jelentésváltozásának forrása éppen az ilyen alkalmi jellegü jelentésváltozás (Márton 1972: 48-49). Különösen értékes és a korábbi szakirodalomhoz képest újnak mondható a kölcsönszó és a magyar jelentésbeli párja között létrejövő jelentésmegoszlás jelenségnek leírása. Ebből is kiderül, hogy az átvétel és a magyar megfelelője között kölcsönös függőségi viszony alakulhat ki, és ennek következményeként ezek nem csupán elkülönülnek egymástól olyan módon, hogy egyiknek módosul a jelentése, hanem mindkét lexéma jelentésszükülésen mehet át (pl. tányér 'cseréptányér': fárfuria 'porcelántányér'.) Ehhez kapcsolódik az 1960-as tanulmányában ismertetett, a tükörfordítás témakörébe sorolható folyamat, amely arra vet fényt, miként hat a magyar szinonim párjára egy-egy román lexéma jelentésszerkezete (az ül igének például a moldvai csángóban 'lakik' jelentése is kialakult a román a sta hatására.) Ezzel Márton Gyula egy olyan jelenségre irányította a kutatók figyelmét, amely nemcsak a moldvai csángóknál fordul elő, de számos erdélyi nyelvváltozatban is, és napjainkban különösen terjedőben van. Márton Gyula román hatással kapcsolatos munkáságának jelentősége több szempontból is értékes: összegezte a korábbi csángó adatokat, és újabb kutatásokkal hozzájárult a csángó kölcsönszókincs gazdagításához (2690 szavas adattárat hozott létre), a RK szerkesztőjeként jelentős mértékben előmozdította a magyar nyelvjárások román kölcsönszavainak a feltérképezését, elsőként tett kísérletet az átvételek hangtani, alaktani, jelentéstani integrációjának részletesebb bemutatására.

A Kis-Szamos vidéki magyar tájszólás román kölcsönszavai címmel 1979ben jelent meg Zsemlyei Ján os 1974-ben megvédett doktori értekezésének rövidített kiadása. A mű egyetlen tájszólás román hatásának monografikus feldolgozása. Ilyen értelemben ez is úttörő munka. Ha a kutató egy tájszólást vizsgál, az számos előnnyel járhat: egyrészt kiderül, hogy bizonyos jelentésmezők rendkívül gazdagok kölcsönelemekben, másrészt pontosabban kimutatható a helyi román nyelvjárás rendszerének hatása (és ezáltal könnyebben elkerülhetők a kizárólag standard románnal történő összehasonlítás csapdái); ugyanakkor tisztában láthatóvá válik az átvétel útja a kezdeti használati ingadozástól a meghonosodásig a szomszéd települések adatai alapján. A jelentéstani fejezetben Zsemlyei János minden korábbi szemantikai alapú megközelítésnél részletesebben vizsgálja a 
kölcsönszavak ilyen természetű folyamatait. Így a poliszemantikus viszonyok keretében a metonimikus és metaforikus jelentésváltozások a maguk sokoldalúságával, jól átgondolt osztályozási rendszer alapján kerülnek bemutatásra. A szerző továbbá érinti a hasonló hangalakú szavak érintkezésének problémáját is, de az ilyen jellegü adatok viszonylag kis száma miatt ezt nem részletezi. Kiemelendő a fejezetnek az a része, amely a kölcsönszavak motiváltságával és jelentésbeli funkcióival foglalkozik. Ezeknél a kérdéseknél vetődik fel először komolyabban a kölcsönszó hangalaki és jelentésbeli expresszivitásának kérdése. A jelentésváltozások a jelentés- és a névátvitel kategóriáiban értelmeződnek.

Ugyancsak a 60-as években irányul a gyüjtők figyelme a különböző szakmai nyelvváltozatokat ért román hatás felderítésére. Kósa Ferenc, Vöő István és Zsemlyei János az erdélyi és moldvai fazekasság szakszókincsére vonatkozó lexémák gyűjtése során felfigyeltek a román hatásra is, és külön tanulmányokban ismertették az erre vonatkozó észrevételeiket (Kósa 1963, Kósa-Vöő-Zsemlyei 1966).

1977-ben jelent meg Márton Gyula, Péntek János és Vöő István szerkesztésében $A$ magyar nyelvjárások román kölcsönszavai (RK). Ez a mű mindmáig a XX. században érvényesülő román nyelvi hatás egyik leggazdagabb forrása. A szócikkek magukba ötvözik Márton Gyula és Zsemlyei János gyüjtésének eredményeit, valamint számos tanulmány, tájszótár, nyelvatlasz (MNyjA, RMNyjA), néprajzi, kultúrtörténeti és szépirodalmi mú adatát. A monográfia sokoldalúságát szemlélteti az is, hogy a szókincs nem korlátozódik csupán a nyelvjárási gyưjtésekre, hanem felöleli az irodalmi, a regionális köznyelv, a közigazgatás, a szolgáltatások, a szakmai nyelvváltozatok rétegét is. A bemutatott kölcsönszavak kapcsán felmerülő hangtani, alaktani, jelentéstani problémákhoz a szerzők rövid magyarázatokat füznek, és ismertetik az odavágó szakirodalmat is. A poliszém alakok minden egyes jelentéséhez feltüntetik az alakváltozatokat és a gyűjtés helyét is. Ezek az utalások megkönnyíthetik a jelentésrelációk értelmezését. A szerzők az elérhető román szótárakban, nyelvjárási atlaszokban ellenőrizték az etimonok jelentéseit, és csak ezután vontak le következtetéseket az esetleges magyar jelentésbeli módosulásról. A szótárról született recenziók egyöntetüen elismerik a mü jelentőségét. A legkritikusabb írás a Murádin Lászlóé (1979). A Bevezetésben említett kölcsönszó terminus használatára vonatkozó megjegyzése mellett a tanulmány szerzője kifogásolja, hogy a szerkesztők nem dolgoztak fel kellő mennyiségü szépirodalmi és publicisztikai anyagot. Ez a kritikai észrevétel csak részben helytálló lévén, hogy a kölcsönszavak gyüjtése a kisebbségi nyelvhasználat esetében soha nem lehet teljes. Murádin másik észrevétele szerint a szerkesztők nagyobb mértékben megrostálhatták volna a gyűjtés anyagát, 
hiszen olyan nyelvi elemek is bekerültek a szótárba, amelyek rendszerint a kétnyelvűség eredményeként alkalomszerűen, esetlegesen tünnek fel az „átvevő nyelv szókincsének a peremén”. Itt a hapax alakokra történik utalás, és a kétnyelvű személyek anyanyelvi kompetenciájának szempontjából éppen hogy ezek a legértékesebb adatok. Ezek alapján árnyaltabban megítélhetjük, hogy melyek azok a területek, amelyekben a kétnyelvüségi helyzetben élők anyanyelvi szókincse fogyatékosabb, funkcionális szempontból háttérbe szorult. Murádin László bírálata jogosnak látszik, amikor néhány olyan lexémára hívja fel a figyelmet, amelyeknek román eredete erősen vitatható (kokonya, kolop, rámpa, rühes, sóp). Ezek a szláv vagy német eredetüek is lehetnek nyelvünkben. Megítélésem szerint a probléma itt az, hogy a viszonyítási alapot nem az egységesnek feltételezett magyar nyelvnek kell képeznie, hanem a különböző területi változataiban élő, sokszínű, sokirányú hatásnak kitett magyar nyelv. Így elképzelhetők olyan kölcsönelemek, amelyek több irányból is beszivároghattak a nyelv változataiba, és joggal beszélhetünk arról, hogy egy kölcsönelem egyaránt árulkodhat szláv, illetve román hatásról anélkül, hogy a két feltételezés kizárná egymást (l. a többszörös etimológia kérdését Bakos monográfiájában). Tehát az eredet kérdését nem szabad mereven egyetlen iránnyal összekötni. Mindez azonban nem jelenti azt, hogy minden alkalommal többirányú eredetet kell feltételezni, csupán annyit, hogy rugalmasabban kell megítélni a származás kérdését.

A RK szerzői közül Péntek János a szótár megjelenése után is folytatta a román nyelvi hatás kutatását. Murádin Lászlónak a kölcsönszó terminus használatát érintő bírálatára is válaszolva, egy önálló szemantikai tárgyú tanulmányában hívja fel a figyelmet arra, hogy az összeállított gazdag kölcsönszóanyag milyen lehetőségeket biztosít az élő szemantikai folyamatok kutatására (1981). Péntek János későbbi írásaiban erőteljesebb mértékben érvényesül a szociolingvisztikai szemlélet, valamint a kisebbségi nyelvhasználat, nyelvi jogok és nyelvvesztés problémakörének kérdései, amelyeknek tárgyalásakor elkerülhetetlenül szóba jön a román mint államnyelv és a magyar mint kisebbségi nyelv viszonya (Péntek 1993, 1994, 1996). Ezek a tanulmányok nem csupán a lexikális hatás kérdéseit érintik, de a morfológiai, szintaktikai problémákat is (az analitikus szerkezetek uralma, nem standard szórend stb.), és egyben a nyelvi interferencia széles kontextusban, újabb (szocio-, pszicholingvisztikai) módszerekkel való vizsgálatát is szorgalmazzák.

A román-magyar nyelvi interferencia kutatásának mindmáig egyik legjelentősebb és legalaposabb müve, B a kos Feren c: A magyar szókészlet román elemeinek története, 1982-ben jelent meg. A mü több mint két évtizedes gyűjtő és adatfeldolgozó munka eredménye. A monográfia szemléletét a di- 
akrón beállítottság jellemzi. A kölcsönelemek a történetiség szempontjából kerülnek bemutatatásra, és jelentőségük megítélése elterjedtségük, szociális értékük szerint történik. A hapax vagy szórványos előfordulású elemek ilyen értelemben majdnem teljesen háttérbe szorulnak. Ez részben érthető is, hiszen Bakos Ferenc nézőpontját a román nyelv hatásának a mértéke, elterjedtsége határozza meg, és nem az, hogy a kölcsönszókincs elemzése milyen tanulságokkal szolgál a kétnyelvűek és általában a kisebbségi helyzetben élők verbális repertoárja és mindennapi kommunikációs stratégiák szempontjából. Ez a különbségtétel Bakos monográfiájának és jelen dolgozat megközelítésnek az eltérésére is utal. Bakos Ferenc a rendkívül gazdag kölcsönszóanyagot szinte kizárólag a kulturális kölcsönzési modell alapján értelmezi. (E közismert elmélet szerint azért veszünk át más nyelvekből szavakat, mert azok olyan más kultúrához kötődő fogalmakat jelölnek, amelyeknek nincs lexikalizálódott megfelelője a nyelvünkben.) Mivel a fogalmi apparátus, amellyel a vizsgálat tárgyát megközelítjük, egyben meg is határozza, hogy mit veszünk észre, természetes, hogy a mủben az ilyen jellegű utalások kerülnek elötérbe, jelentős mértékben ezek határozzák meg a kölcsönzési motiváció problematikájának értelmezését. A kétnyelvűség pszichológiája és a társadalom-lélektani tényezők, a nyelv szemantikai dimenziójának kategorizációs rendszere, a hangalaki és a szemantikai expresszivitás kérdései hiányoznak vagy csak egy-egy megjegyzés erejéig kerülnek szóba. Ha megnézzük a kölcsönszókészlet fogalmi körök szerinti osztályozását, akkor ebből kitűnik, hogy a „vegyes, közelebbről nem csoportosítható" kategóriába kerülnek olyan kölcsönelemek, amelyek az onomatopoézissel, hangalaki expresszivitással jellemezhetők (bakanyál 'ütöget'; binzag 'döngicsél'; bizajál 'zümmög'; bubojál 'lobogva ég'; bulbucsál, bulbukál 'bugyborékol'; cucuráz 'ráncigál, cibál'; csokonyál 'vág, ver, ütöget'; dripejál 'dörömböl, döngöl'; durdukálódik 'hánykolódik, hengergőzik'; fircál 'sürög-forog'; gidil 'csiklandoz'; háukál 'csahol'; mormojál 'mormol'; ninejál 'döngicsél' stb. - i.m. 450-452.) Ez valószínűleg azért történt, mert a kulturális kölcsönzési modellben nemigen van helye a hangalaki kifejezőerő kérdésének. Úgy tûnik, hogy a jelentés pragmatikai vonatkozásainak bizonyos aspektusai is háttérbe szorulnak ebben a megközelítésben. A vegyes szóanyag csoportjába kerülnek a tettértékű beszéd-megnyilvánulás kifejezői (pl. káromkodás, felszólítás), érzelmi megnyilvánulások jelölői és a fatikus elemek is: bátetye norokul 'vigyen el a kánya'; dámnye 'uram isten'; drum bun 'indulás, indulj'; gátá 'készen van'; hajda 'rajta'; naptye bune 'kész van, végeztem'; septye-opty 'a kutyafáját'!; simáj 'rajta'; szusz 'nosza!'; tács! 'hallgas'; usá! 'takarodj' stb. Ez azért is furcsa, mert a szerző korábban utal a nyelvi tabu és az újszerűséggel összefüggő kifejező érték jelenségére (i.m. 108-109). 
Különösen értékes a magyar szemantikai rendszer hatására történő jelentésváltozások ismertetése (97-8. oldal). Ebből megtudhatjuk, hogy számos kölcsönelem a magyar nyelvi jelentéshálózatokba integrálódva új szemantikai tartalommal gazdagodott. Az ilyen módon létrejött jelentések szinte kivétel nélkül metaforikus természetűek, bár Bakos ezt nem jelzi, sőt külön tárgyalja azokat, amelyek metaforás névátvitelek eredményei, és azokat, amelyeknek jelentése a „magyar szókészleti rendszer vonzására" változott meg (97.old.). Ez utóbbi kategóriába kerül az eredetileg 'fon' jelentésü drugál, amely a magyar fon másodlagos - névátviteles - jelentésének hatásaként felvette a 'dorombol (a macska)' jelentést is. Hasonlóképpen a picus a magyar cica származékjelentésének köszönhetően 'barka', a puca pedig az angyalbögyörő hatására 'krumplinudli' jelentéssel gazdagodott. Ezek szintén a magyar nyelv metaforikus viszonyhálózatának a termékei, akárcsak azok a jelentésváltozások némelyike, amelyeket Bakos metaforás átvitel címen tárgyal: putina 'fabödön' $\rightarrow$ 'kövér kisgyermek' buglán 'hordó' $\rightarrow$ 'kövér ember', a cáp 'bakkecske' $\rightarrow$ 'öregember, aki fiatalságában kicsapongott' (a jelenséggel részletesen foglalkozom a doktori értekezésemben: Benő 2004).

Szilágyi N. Sánd or új szempontból közelíti meg a román-magyar szókölcsönzés kérdését. Ố a nyelvi érintkezés kapcsán egy olyan szociálpszichológiai nézőpontra hívta fel a figyelmet, amely korábban nem jelent meg a szókölcsönzés indítékai között (2007). A minden etnikai közösségre jellemző etnocentrikus szemléletről van szó. Ennek a szempontnak az érvényességét azért is fontos megvizsgálni nyelvi anyagon, mert magyarázatul szolgálhat az olyan szemantikai folyamatok értelmezéséhez, mint a pejoratív jelentésváltozás vagy a negatív irányba történő értékjelentés-eltolódás (l. a VIII.6. alfejezetet).

A román-magyar nyelvi érintkezés vizsgálata az elmúlt években is sok újabb szemponttal és részeredménnyel gazdagodott. Romániai viszonylatban intézményesen a Szabó T. Attila Nyelvi Intézet vállalta a magyar-román kétnyelvűségi kutatások és nyelvi érintkezés vizsgálatának koordinálását Péntek János szakmai irányításával. Ebben a témakörben a korpusztervezéssel is összefüggő lexikográfiai (vö. Benő 2009b) és korpusznyelvészeti (pl. a Termini magyar nyelvi szótár és adatbázis) munkák sora keletkezett, kontaktológiát is érintő tanulmányok, rendezvények zajlottak; cikkek, tanulmánykötetek jelentek meg. Az Anyanyelvápolók Erdélyi Szövetségének gondozásában, a Szabó T. Attila Nyelvi Intézet Kiadványai sorozatában hét kötet jelent meg eddig, melyek a nyelvi kölcsönhatás tényezőivel, formáival, kontextusával, nyelvi és jogi vonatkozásával foglalkoznak (Péntek-Benő 2003b, Péntek-Benő szerk. 2005, Benő-Szilágyi N. 
szerk. 2006, Benő-Fazakas-Szilágyi N. szerk. 2007, Bálint-Péntek szerk. 2009, Gál 2010, Bálint 2013).

A kontaktusvizsgálatok eredményeinek bemutatásához rendszeresen lehetőséget biztosított az Élőnyelvi konferencia-sorozat, és a konferenciákon elhangzott előadások publikált szövegei. Kolozsvár volt a színhelye a 13. Élônyelvi konferenciának 2004-ben a Szabó T. Attila Nyelvi Intézet és a Magyar Nyelvészeti Tanszék szervezésében. A konferencia anyaga megjelent kötet formában (Benő-Szilágyi szerk. 2006). A kontaktológia a kolozsvári tanszéken egyetemi tantárggyá is vált, és ehhez szolgál 2008 óta oktatási segédletként egy egyetemi jegyzet (Benő 2008). Doktori disszertációm is kontaktológiai témát, a kölcsönszó jelentésbeli folyamatait vizsgálja kognitív szemantikai és szociálpszichológiai keretben (Benő 2004a); általánosabb kérdéseket tárgyal Péntek 2001b. A nyelvi kontaktusok és etnikai folyamatok kapcsolataival Kádár Edit (2006, 2008), és Péntek János (2001, 2008, 2010) foglalkozik.

Végkövetkeztetésként elmondhatjuk, hogy az eddigi jelentős eredmények ellenére még mindig vannak megoldatlan vagy kellően nem tisztázott kérdések a román-magyar nyelvi érintkezés folyamatairól. Ilyenek a közvetett kölcsönzések vizsgálata, a tulajdonnév-kölcsönzés, illetve a kontaktusjelenségek szociális, nyelvi jogi kontextusokban való láttatása. A megfelelő fejezetben ezeket a vonatkozásokat is elemzem, és jelzem a további kutatások tárgyául szolgáló kérdéseket. 


\section{A ROMÁNIAI MAGYAR NYELVVÁLTOZAT SZOCIOLINGVISZTIKAI HELYZETÉNEK ÖSSZEGZŐ BEMUTATÁSA, KÜLÖNÖS TEKINTETTEL A DEMOGRÁFIA, AZ OKTATÁS ÉS A NYELVI JOGOK KÉRDÉSÉRE}

Mint ismert, a nyelvi érintkezések nem légüres térben zajlanak, hanem földrajzi térben és időben meghatározható módon, interkulturális és szociális kontextusban érintkező konkrét nyelvi közösségek és nyelvváltozatok szintjén. Ha a nyelvi kontaktusfolyamatok miértjeire kívánunk válaszolni, akkor mindenképpen szem előtt kell tartanunk az adott kétnyelvűség típusát, annak folyamatát meghatározó gazdasági, szociális és kulturális tényezőket. Jól szemlélteti ezt az összefüggést a konkrét kontaktusfolyamatok és a társadalmi-gazdasági tényezők között az erdélyi magyar nyelvváltozat különböző regisztereiben használt román eredetü közvetlen lexikai átvételek kérdése. Az eddigi vizsgálatok ugyanis kimutatták, hogy a kölcsönszavak legjelentősebb kölcsönszókészleti rétegnek tekinthető az átvételeknek az az állománya, amely a hivatali, közigazgatási nyelvből, általában a szaknyelvből és szakmai nyelvhasználatból ered (Péntek 1999: 43). A lexikai kölcsönszóréteg ilyen jellegű mennyiségi vizsgálatai azt jelezték, hogy a legelterjedtebb lexikai kölcsönelemek (azok, amelyek nem kizárólag tájnyelviek, hanem előfordulnak regionális köznyelvi vagy népnyelvi szinten), mintegy 50\%-a a hivatali nyelvhasználatból származik (Benő 2007a: 116). Az erdélyi magyar nyelvhasználatnak ez a szókészleti jellemzője nyilvánvaló összefüggésben van a romániai nyelvi jogok kérdésével, azzal a ténnyel, hogy az erdélyi magyar nyelv évtizedekig kívül rekedt a hivatalos használat körén, és a beszélők leginkább államnyelven találkoztak és találkoznak bizonyos hivatali megnevezésekkel, terminusokkal. ${ }^{5}$ Hasonló módon a szakregiszterekből származó kölcsönszavak

\footnotetext{
${ }^{5}$ Itt olyan kölcsönszavakra kell gondolnunk, amelyek a hivatalos iratokra, intézményekre, közigazgatási fogalmakra vonatkoznak: Ilyenek például a következők: abonament 'bérlet', ángázsál 'alkalmaz', aprobál 'jóvá hagy', csertifikát 'igazolás', decsizió 'bírósági döntés', delegát 'megbízott, kiküldött', flotánt 'ideiglenesen bejelentett lakos', inventár 'leltár', kitánca 'nyugta', média 'általános osztályzat', notár 'jegyzo"', patron 'tulajdonos', pérmisz 'engedély', primarija
} 
nagy száma összefüggésben van azzal a jelenséggel, hogy a szakoktatás számos területen csak az államnyelven történik, és a magyar anyanyelvü fiatalok nem sajátítják el magyar nyelven a szakterminológiát, ennek következtében pedig magyar nyelvi közléseikben gyakran kénytelenek román eredetü idegen szavakat használni.

Mindez azt jelzi, hogy egy nyelvi kontaktushelyzet bemutatásakor utalnunk kell az érintkező nyelvi közösségek mennyiségi viszonyára és a demográfiai tényezőkre, a gazdasági-társadalmi dominanciára, az érintkező nyelvi közösségek jogi státusára (és ezzel összefüggésben a nyelvhasználati színterekre), a kétnyelvűség, többnyelvűség arányára és ezek típusaira.

\section{Az érintkező nyelvi közösségek státusa és demográfiai adatai}

Ismert, hogy a román-magyar nyelvi érintkezés Erdélyben több évszázada tartó, közvetlen, kölcsönös népi érintkezésnek tekinthető. ${ }^{6}$ A 20. században az önkényes határmódosítások következtében az erdélyi magyarság kisebbségi jogi státusba került, és ez a kisebbségi helyzet mind a mai napig bizonyos mértékü jogfosztottságot jelent az anyanyelvhasználat szempontjából, és ez felerősítette az elmúlt évtizedekben a román nyelv hatásának a mértékét. A nyelvi közösségi korábbi kétoldalú nyelvi érintkezése mára nagyobbrészt egyoldalúvá, aszimmetrikussá vált. Az egyoldalúság megnyilvánul abban, hogy ma Erdélyben főleg a román nyelv magyarra gyakorolt hatásáról beszélhetünk, és szinte egyáltalán nem a magyar nyelv hatásáról a románra. Az aszimmetrikusságot az is jelzi, hogy a két nyelvi közösség viszonylatában a közös kód szerepét az államnyelv tölti be, és hogy a kisebbségiek nagy hányada kétnyelvü, míg a többségiek rendszerint egynyelvűek, és így a hivatalos információáramlás egyoldalú (Péntek 1999: 45). Ehhez járul még az a tény, hogy a román nyelv hivatalos jogi státust élvez, míg a magyar nyelv használata korlátozott az oktatásban, az igazságszolgáltatásban, a közigazgatásban, az egészségügyben.

Ezt az aszimmetriát látszik igazolni az erdélyi magyarok nyelvi kompetenciájára vonatkozó felmérések. A legutóbbi, reprezentatív mintavétellel készült 2009-es szociolingvisztikai felmérés adatai szerint az erdélyi magyarok román nyelvismerete a következők szerint oszlik meg a

'polgármesteri hivatal', szekretáriát 'titkárság', szérélé 'kft', tárif 'díjszabás', vékimé 'szolgálati idő' stb.

${ }^{6}$ A román nyelvet ért magyar nyelvi hatással kapcsolatban 1. Tamás 1966, Kis 1975, Király 1990, Benő 2004a. 
vizsgált minta szerint: anyanyelvi szinten beszél: 10,6\%, „,tökéletesen” beszél: $24,8 \%$, nagyon jól, akcentussal: 27,4\%, nem nagyon jól, de meg tudja értetni magát: $21,1 \%$, és csak $15,2 \%$-uk vallotta azt, hogy nehezen tudja megértetni magát, vagy alig pár szót ismer. ${ }^{7}$ Tehát az önbevallás szerint az erdélyi magyarok 85-90\% ismeri és használni tudja az államnyelvet. Az erdélyi románok körében a magyar nyelv ismerete ettől teljes mértékben eltérő képet mutat, egy korábbi felmérés szerint ugyanis 75\%-uk azt vallotta, hogy egyáltalán nem tud magyarul, vagy csak alig néhány szót ért, és csak 7,5\% -uk gondolta úgy, hogy nagyon jól vagy tökéletesen beszél magyarul (Horváth 2003).

Az erdélyi magyarok d em og ráfiai a d a tai azt jelzik, hogy az elmúlt évtizedekben a számuk és arányuk jelentős mértékben változott, amint ezt az 1. táblázat szemlélteti:

\begin{tabular}{|c|c|c|c|}
\hline Év & Erdély lakossága & $\begin{array}{c}\text { Erdélyben élő románok } \\
\text { száma és aránya }\end{array}$ & $\begin{array}{c}\text { Erélyi magyarok száma } \\
\text { és aránya }\end{array}$ \\
\hline 1930 & 5520086 & $3189537(57,78 \%)$ & $1349563(24,44 \%)$ \\
\hline 1956 & 6218427 & $4041156(64,98 \%)$ & $1558254(25,05 \%)$ \\
\hline 1966 & 6719555 & $4559432(67,85 \%)$ & $1597438(23,77 \%)$ \\
\hline 1977 & 7500229 & $5203846(69,38 \%)$ & $1691048(22,54 \%)$ \\
\hline 1992 & 7723313 & $5684142(73,59 \%)$ & $1603923(20,76 \%)$ \\
\hline 2002 & 7221733 & $5393552(74,69 \%)$ & $1415718(19,60 \%)$ \\
\hline 2011 & 6475894 & $4818065(74,40 \%)$ & $1223394(18,90 \%)$ \\
\hline
\end{tabular}

1. táblázat. Erdélyi magyarok és románok számának és arányának változása Erdélyben (1930-2011) (Forrás: Benó-Szilágyi 2005)

A népszámlálások tanúsága szerint az erdélyi magyarok aránya tehát az 1956 óta folyamatosan csökkent, míg az erdélyi románok aránya fokozatosan növekedett 2002-ig. Megjegyzendő, hogy a 2011-es népszámlálás adatai szerint Romániában összesen 1238000 személy vallotta magát magyarnak, míg Erdélyben 1223394 személy tette ezt, tehát közel tizenötezer magyar nem Erdélyben él, hanem Moldvában, Bukarestben és más Kárpátokon túli településeken.

\footnotetext{
${ }^{7}$ 2009-ben a kolozsvári Nemzeti Kisebbségkutató Intézet (ispmn.gov.ro/hu/) reprezentatív mintán szociológiai és szociolingvisztikai kérdőíves felmérést végzett a romániai magyarok körében Demográfia, rétegződés, nyelvhasználat címen. Az erdélyi magyarok nyelvismeretére vonatkozó adatok ebből a kutatásból származnak. (Itt szeretném kifejezni köszönetemet Horváth Istvánnak és munkatársainak, hogy hozzáférhetővé tették számomra a 2009-es felmérés teljes adattárát.)
} 
Az elmúlt évtizedekben az erdélyi magyarok társadalomszerkezete is jelentősen megváltozott. Trianonig az erdélyi magyarságnak erős középosztálya volt, és a románokhoz viszonyítva felülreprezentált volt olyan társadalmi rétegek tekintetében, mint a földbirtokosok, iparosok, hivatalnokok, értelmiségiek (Sorbán 2011: 27). Az 1945 utáni homogenizáló társadalmi és gazdasági politika következtében jelentős mértékben megváltozott, homogenizálódott: a középosztály aránya erőteljesen csökkent. Jól mutatja ezt az értelmiségiek arányának folyamatos csökkenése is. 1992-re az erdélyi magyaroknak már csak 3,7\%-ának volt felsőfokú végzettsége, míg a románok körében ez az arány 5,1\% volt. (A különbség jelentős abszolút számokban kifejezve, hiszen ez az aránytalanság kb. 20 ezerrel kevesebb magyar felsőfokú végzettségű személyt jelent.) Ezt a társadalomszerkezeti átalalakulást tervezett urbanizáció és asszimilációs célokat követő kisebbégpolitika kísérte. Ezek a tényezők hatással voltak a nyelvhasználatra, a szaknyelvek helyzetére. Hagyományos magyar nyelvi színterek számolódtak fel, szaknyelvi regiszterek épültek le, és a funkcionális nyelvvesztés jeleként tapsztalhatóvá váltak a nyelvi hiány tünetei a magyar szaknyelvi kommunikációban (Péntek 2001: 154-156).

A felsőfokú iskolázottságra vonatkozó etnikai és nyelvi alapú aránytalanság az 1989-1990-es rendszerváltással sem szűnt meg, hiszen a 2002-es népszámlálási adatok szerint legalább egyharmaddal kisebb az aránya a felsőfokú végzettséggel rendelkező személyeknek a romániai magyarok körében: a tíz éven felüli népesség szempontjából a románok 7,34\%-a felsőfokú végzettségünek mondható, miközben a magyarok körében ez az arány $4,91 \%$ tesz ki (2. táblázat).

\begin{tabular}{|l|c|c|c|c|c|c|}
\hline Nemzetiség & $\begin{array}{c}\text { Felső- } \\
\text { fokú }\end{array}$ & $\begin{array}{c}\text { Posztliceális } \\
\text { és mesteri }\end{array}$ & $\begin{array}{c}\text { Közép- } \\
\text { fokú }\end{array}$ & $\begin{array}{c}\text { Alap- } \\
\text { fokú }\end{array}$ & $\begin{array}{c}\text { Befejezett } \\
\text { iskola } \\
\text { nélkül }\end{array}$ & $\begin{array}{c}\text { Nem } \\
\text { válaszolt }\end{array}$ \\
\hline Összesen & 7,05 & 2,96 & 64,27 & 20,06 & 5,57 & 0,06 \\
\hline \multicolumn{7}{|l|}{} \\
\hline Román & 7,34 & 3,04 & 64,64 & 19,88 & 5,01 & 0,05 \\
\hline Magyar & 4,91 & 2,89 & 70,89 & 17,62 & 3,61 & 0,05 \\
\hline
\end{tabular}

2. táblázat. A 10 éven felüli népesség iskolázottsága nemzetiség szerint a 2002. évi népszámlálás alapján (\%) (Forrás: Sorbán 2011: 32)

Ugyanezt a kisebbségi-többségi szociális aszimmetriát tükrözte a 2002es népszámlás a foglalkozási szerkezet és a társadalmi státus tekintetében. Bizonyos foglalkozások, beosztások körében ugyanis a magyarok az országos átlagnál sokkal kisebb mértékben képviseltek: ilyennek tekinthetők az 
olyan munkakörök, amelyeket a törvényhozók, vezetők, az értelmiségiek és a tudományos foglalkozásúak töltenek be. Ugyanakkor az is megfigyelhető a 2002-es adatokból, hogy az erdélyi magyarok körében magasabb a szakképzetlenek aránya, ami egyenes következménye az anyanyelvü szakoktatás hiányosságainak (3. táblázat).

\begin{tabular}{|l|c|c|}
\hline Foglalkozások, beosztások & Romániában & Romániai magyarok körében \\
\hline Törvényhozók és vezetők & $4,0 \%$ & $3,4 \%$ \\
\hline $\begin{array}{l}\text { Értelmiségi és tudományos } \\
\text { foglalkozásúak }\end{array}$ & $8,2 \%$ & $6,1 \%$ \\
\hline Szakképzetlenek & $7,5 \%$ & $8,6 \%$ \\
\hline
\end{tabular}

3. táblázat. Foglalkozási rétegzödés összehasonlitása Románia és a romániai magyarok tekintetében a jelentôsebb eltérést mutató munkakörök szempontjából (Forrás: Veres 2007)

A felmérések eredménye szerint a kedvezőtlen demográfiai és társadalomszerkezeti helyzet ellenére az erdélyi magyarok nemzeti öntudata, identitása erősnek mondható: ragaszkodnak magyarságukhoz és nemzeti alapon összetartozónak érzik magukat a magyarországiakkal, a többi külső régió magyarjaival (Péntek-Csernicskó 2011: 197). A magyar nyelv presztízse az erdélyi magyarok körében magasnak tekinthető, sőt a helyi regionális magyar nyelvváltozat értékelése más magyar nyelvváltozatok tekintetében is kiemelkedő. A 2009-es szociológiai és szociolingvisztikai felmérés ${ }^{8}$ eredményei azt jelezik, hogy az erdélyi magyarok közel 75\%-a úgy véli, hogy Erdélyben beszélnek a legszebben magyarul (Benő 2012), amint ezt az 1-es számú ábra szemlélteti:

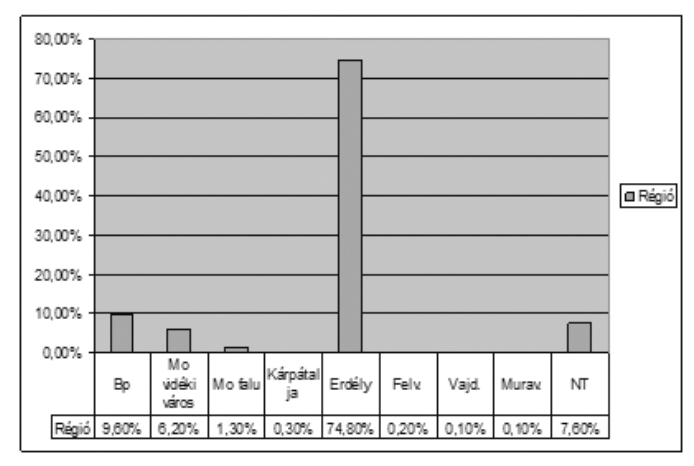

1. ábra. A Hol beszélnek a legszebben magyarul? kérdésre adott válaszok megoszlása a preferált regionális nyelvváltozatok alapján

\footnotetext{
${ }^{8}$ Demográfia, rétegzódés, nyelvhasználat (2009)
} 
Ugyanakkor az sem mellékes tényező a jelenben zajló és a jövőbeli nyelvi attitüdök és folyamatok szempontjából, hogy az általában szépnek és értékesnek tartott és erdélyi magyar nyelv mellett jelentős arányban választják a magyar szülők az állam hivatalos nyelven való tanulást különböző előítéletek és sztereotípiák miatt (Sorbán 2000), ami egyben azt is jelzi, hogy az anyanyelvváltozat presztízse és az államnyelv magas jogi státusa egyfajta versengésben van egymással.

\section{A nyelvi jogok kérdése}

Ismert, hogy a diktatúrák bukásával az egész kelet-európai térségben kétségtelenül kedvező változás következett be azzal, hogy lehetővé vált a nyelvi jogok igénylése, a jogigény megfogalmazása és képviselete az illető ország törvényhozásában. Kedvező az is, hogy elindult, és jelenleg még tart a nyelvi jogok kiterjesztésének és biztosításának folyamata az illetékes európai intézményekben. Ennek következtében általában javult a magyar nyelv jogi státusa a külső régiókban. Nem történt azonban olyan áttörés, amely a szlovéniai Muravidékhez hasonlóan, máshol is legalább regionálisan biztosítaná a magyar nyelv hivatalos státusát. Ezt a nyelvi környezet föltétlenül indokolná Erdélyben (legalább a Székelyföldön), de a többi peremrégióban is. Nem változott alapvetően az állam nyelvpolitikai ideológiája, azaz továbbra is sokkal inkább asszimilációs, mint pluralista, egyenjogúsító.

Változást jelent viszont az, hogy a megvalósultak a feltételei a jogigény kinyilvánításának és határozott képviseletének a jogi kodifikációban. A kisebbségi közösségnek a parlamentbe bekerült képviselői a legitimitásuk és politikai mozgásterük révén hangot adnak ezeknek a jogigényeknek. Az ő felelösségük, hogy a többség és a kisebbség politikai harcában akár a nemzetközi fórumok előtt is képviseljék a nyelvhasználati és egyéb kisebbségi jogokat, és hogy folyamatosan érvényt szerezzenek azoknak a jogoknak, amelyeket már törvénybe iktattak.

Az ország nemzetállamként való meghatározása és a román nyelv kiemelt hivatalos státusa Romániát azok közé az államok közé helyezi, amelyek egyetlen nyelvnek, a többség nyelvének biztosítanak kiemelt, fölérendelt státust. A nemzetállami modellben az ország nyelvpolitikájában óhatatlanul az asszimiláció ideológiája érvényesül, és az a stratégia, amely közelebb viszi a nemzetállamot az „egy ország - egy nyelv" eszményinek tekintett állapotához. Az alkotmány vitájának időszakában a kisebbségi képviselők között is voltak olyanok, akik naiv optimizmussal úgy vélték, hogy a nemzetállam statuálása csak szimbolikus értékű. Az azóta eltelt időszakban bebizonyosodott, hogy ennek meghatározó jelentősége van 
mind a további kodifikációs gyakorlatban, mind a nemzetpolitika és a közhangulat (tolerancia, intolerancia stb.) alakításában. A nyelv hivatalos státusát pedig a mindennapi életben a helyi hatóságok többnyire azonosítják a publikus nyelv kategóriájával, a nem hivatalos nyelvek így a nyilvános használatban hátrányos helyzetbe kerülnek. Szintén a hivatalos nyelv kategóriájával kerül szándékoltan hamis oppozícióba az idegen nyelv kategóriája. Minden bizonnyal ennek a következménye, hogy például az oktatási hatóságok hivatalos terminológiájában az anyanyelv csak a kisebbségekre érvényes kategória, a felsőoktatási szakok hivatalos jegyzékében pedig ez az "anyanyelv" is az idegen nyelvek csoportjába kerül (vagy egy másik lehetséges értelmezés szerint nem is történik róluk említés). A hatóság politikai gyakorlatában az esélyegyenlőség az oktatásban nem kinek-kinek az anyanyelvére épül, hanem ",a közös" hivatalos nyelvre, és így ez már eleve diszkriminatív (Péntek-Benő 2003a). ${ }^{9}$

Románia 1991-es al k o tm á n yát 2003-ban módosították. Ennek kettős jelentősége van: egyrészt az organikus törvényi szinten biztosított nyelvi jogokat alkotmányos szintre emeli, így garantálja azokat, másrészt pedig kiterjeszti az anyanyelv-használati jogok területét az önkormányzati igazgatásról a területi (dekoncentrált) államigazgatásra. Az alkotmány 6. szakasza a nyelvhasználati szempontból fontos identitáshoz való jogot rögzíti: az állam elismeri és garantálja a nemzeti kisebbségekhez tartozó személyek jogát identitásuk megőrzéséhez, fejlesztéséhez és kifejezéséhez, illetve tiltja a bármilyen jellegű diszkriminációt, ami a pozitív diszkrimináció tiltásaként értelmezhető, a kisebbségi közösségek pozitív diszkriminációjának tilalmaként. ${ }^{10}$

Az alkotmány a nem hivatalos kisebbségi nyelvek használatát az igazságszolgáltatás területén korlátozza, amennyiben úgy közelíti meg a kérdést, hogy a nemzeti kisebbségekhez tartozó személyek és az idegenek, akik nem beszélnek románul tolmácsra jogosultak a büntetőeljárások esetében, és ez explicit módon azt jelenti, hogy a polgári perekben nem jogosultak díjmentesen biztosított tolmácsra. ${ }^{11}$

\footnotetext{
${ }^{9}$ Kontra Miklós and Szilágyi N. Sándor: Do the Majority-Language Speakers Have a Mother Tongue, or only Minority-Language Speakers Do? (Kézirat) Elhangzott a 2001. ápr. 19-21-én Rigában megrendezett Kis nyelvek a 21. század Európájában c. nemzetközi konferencián.

${ }^{10}$ 6. szakasz: (1) Az állam elismeri és biztosítja a nemzeti kisebbségekhez tartozó személyek jogát az etnikai, kulturális, nyelvi és vallási identitásuk megőrzéséhez, fejlesztéséhez és kifejezéséhez. (2) A nemzeti kisebbségekhez tartozó személyek identitásának megtartását, fejlesztését és kifejezését célzó állami védő intézkedéseknek meg kell felelniük a többi román állampolgárhoz viszonyítva az egyenlöség és a diszkrimináció tilalma elveinek.

${ }^{11} 128$. szakasz, 4. bekezdés: A román nyelvet nem értô vagy nem beszélő idegen állampolgároknak és hontalanoknak jogukban áll tudomást szerezni az iratcsomóba foglalt összes iratról és munkálatról és a bírói hatóság elótt tolmács útján beszélni és következtetéseket megfogalmazni; a büntetöperek esetén e jogot ingyenesen biztosítják.
} 
Akárcsak az alaptörvény, a romániai oktatási és közigazgatási törvény hátrányos elöírásokat is tartalmaz a nem román anyanyelvüek számára.

Bár a 2011-ben elfogadott új oktatási törvény az anyanyelvü képzés, az államnyelv tanítása tekintetében előrelépésnek tekinthető, olyan rendelkezései is vannak, amelyek jelzik az államnyelv kitüntetett szerepét és a kisebbségi nyelvek másodlagos jellegét. A törvény 9. szakaszának 2. bekezdése kötelezővé teszi a román nyelvü oktatást minden településen, és - szükség esetén - kisebbségi nyelveken is, vagy pedig a legközelebbi településen biztosítják a kisebbségiek anyanyelvü iskoláztatását. Mivel nincs pontosan meghatározva, hogy mit jelent a szükség esetén, a bekezdés úgy is értelmezhető, hogy az államnyelven való oktatás nem korlátozható, míg a kisebbségi nyelveken történő iskolai tevékenység igen. Ugyanennek a szakasznak a 4. bekezdése előírja, hogy az iskolai iratokat kötelező módon románul kell kiállítaniuk az oktatási intézményeknek.

A 2001-ben elfogadott román közigazgatási törvény ${ }^{12}$ bizonyos mértékben haladást jelent a kisebbségek nyelvi jogai vonatkozásában, hiszen bővíti a kisebbségi nyelvek használatának színterét. A törvény 17. szakasza meghatározza azokat a feltételeket, amelyek közepette a közigazgatásban használható valamely kisebbségi nyelv:

"Azokban a területi közigazgatási egységekben, amelyekben a lakosság több mint húsz százaléka nemzeti kisebbségekhez tartozó állampolgár, a helyi közigazgatási hatóságoknak biztosítaniuk kell az anyanyelv használatát is a velük fenntartott kapcsolatokban, az Alkotmány, a jelen törvény és a Románia által részes félként aláirt nemzetközi megállapodások elöirásainak megfelelöen."

Megjegyzendő, hogy a 20\%-os határ nem kismértékben korlátozó jellegü, hiszen nagyobb városokban emiatt több ezer vagy tízezer kisebbségi beszélő kerülhet hátrányos helyzetbe, amint ezt Kolozsvár helyzete szemlélteti, ahol - annak ellenére, hogy közel 50.000 magyar anyanyelvü él - ez a rendelkezés nem kerül alkalmazásra, mivel a hatóságok úgy értelmezik, hogy csak $20 \%$ fölött lehetséges, jóllehet a törvény idézett paragrafusa a kötelező jelleget emeli ki, és 20\%-os küszöb alatt nem tiltja annak alkalmazását.

A közigazgatási törvény 90. szakasza szerint a román nyelv a közigazgatás nyelve, és ilyenként korlátlanul használható, a kisebbségi nyelvek csak az említett húszszázalékos feltétel érvényesülésekor türhetők meg a közigazgatásban, amelynek minden pozitív látszat ellenére diszkriminatív éle is van a nagyvárosi szórványban élő kisebbségiekre nézve. Arra is van

\footnotetext{
${ }^{12}$ Legea nr. 215 din 23 aprilie 2001 administraţiei publice locale publicat în Monitorul Oficial al României nr. 204 din 23 aprilie 2001.
} 
példa, hogy a helyi adminisztrációban tevékenykedő magyar képviselet paradox módon nem igényli saját nyelvhasználati jogai érvényesítését, és ezzel rontja az ezzel kapcsolatos jogigény hitelét.

Ugyanennek a szakasznak a 4. bekezdése elöírja, hogy az ismert húszszázalékos feltétellel a közigazgatási hatóságoknak biztosítaniuk kell a helységek és a fennhatóságuk alatt levő közintézmények nevének, valamint a közérdekű hirdetéseknek az illető kisebbséghez tartozó állampolgárok anyanyelvén való feliratozását. A magyar helységnevek használatát továbbra is nehezíti a helyi, többnyire erőszakos ellenkezés.

A 90. szakasz említett 4 . bekezdése önmagában pozitív intézkedés volna, ha a következő bekezdés nem szentesítené az államnyelvek és a kisebbségi nyelvek további egyenlőtlenségét:

\section{„(5) A hivatalos okiratok kötelezően román nyelvek készítendók."}

Ez a bekezdés kizárólagosan fogalmaz, szentesíti a román nyelv kiemelt közigazgatási funkcióját a hivatalos iratok vonatkozásában is. Kétnyelvű hivatalos iratokról nincs említés, lehetőségként fel sem merül.

A közigazgatási törvény kulcsfogalma a helyi autonómia, amelynek értelmezése meglehetősen korlátozott. A helyi autonómia csupán az oszthatatlan egységes nemzeti állam keretén belül érvényesülhet (2. szakasz, 1,2 bekezdés). Erre a szakaszra hivatkozva elutasítható minden olyan kérés, amely a tényleges gazdasági és területi autonómiát szorgalmazza, mivel az nincs pontosan meghatározva, hogy mi az, ami sérti az ország egységes és oszthatatlan nemzeti állam jellegét. A törvény 4 . szakasza egyébként egyértelmúen kimondja, hogy a helyi autonómia kizárólag adminisztratív és pénzügyi jellegü, és a törvény alapján, illetve a törvény által előírt korlátok között gyakorlandó.

Pozitív törvényhozási eseményként értékelhetjük a diszkrimináció megelőzésére és büntetésére vonatkozó törvény elfogadását. ${ }^{13}$ A 2002. január 16-án megszavazott diszkrimináció-ellenes törvény első szakasza kimondja, hogy Romániában mint demokratikus jogállamban az ember méltósága, a polgári szabadságjogok, valamint a személyiség szabad kibontakoztatása a legfőbb értéket jelenti, és ilyenként a törvények által garantált.

Âltalánosan elmondható, hogy Romániában a törvény alkalmazásával gyakran gondok vannak, hiszen jelenleg Románia, a bizonyos kisebbségi jogokat megtagadó, rejtett módon asszimilációs politikát követő nemzetál-

\footnotetext{
${ }^{13}$ Lege nr. 48 din 16 ianuarie 2002 pentru aprobarea Ordonanței Guvernului nr. 137/2000 privind prevenirea şi sancționarea tuturor formelor de discriminare. Monitorul Oficial nr. 69 din 31 ianuarie 2002.
} 
lam és a jogállamiság között ingadozik. A törvény és a törvény alkalmazása közötti szakadék a nemzetközi egyezményekre és a belső jogszabályozásra egyaránt érvényes.

Mindezek mellett kimutatható a nemzetközi törvényeknek egy hallgatólagos romániai értelmezése, amely „a nemzetközileg elismert és egyezményekkel garantált jogok korlátjait és a kivételeket hangsúlyozza, és a szerződések nem egy rendelkezésének általános, tágan értelmezhető jellegét következetesen a jogok beszűkítésére használja fel" (Izsák 2000). Gyakran maguk a nemzetközi alapokmányok kínálnak erre lehetôséget, amikor a kisebbségi jogok érvényesítését olyan feltételekhez kötik, amelyeknek értelmezése nem egyértelmű. Jó példa erre a Regionális és Kisebbségi Nyelvek Európai Chartája, amely számos esetben a rendelkezés súlyát csökkentö, önkényesen is értelmezhető feltételeket is megfogalmaz, mint például: „,amennyire lehetséges”, , adott esetben”, , ahol szükséges”, „a tanulók elégségesnek ítélt számban óhaitják”, , „a kisebbségi beszélők száma szükségessé teszi" stb. (Skutnabb-Kangas 1997: 75).

A joggyakorlat azt mutatja, hogy Románia kifelé elismeri az emberi és kisebbségi jogot, ígéri a nemzetközi megállapodásoknak gyakorlatba ültetését, de a befelé irányuló intézkedések gyakran arra utalnak, hogy a végrehajtó szervek nem mindig tartják szem előtt a nemzetközi dokumentumokban vállalt kötelezettségeket, hiszen „a szerződések értelmezésének általános szabályai fölött a nemzeti etatizmus politikai doktrínája dominál" (Izsák i.m.) Ezt jól mutatják az említett román törvények korlátozó diszkriminációs vonatkozásai, valamint a törvények alkalmazásnak módjai a mindennapi gyakorlatban. Jellemző az a kodifikációs gyakorlat is, hogy az egyes törvények egyértelmű, kedvező előírásait a végrehajtási utasítások hatástalanítják, így a törvény külső megítélése kedvező, belső hatása pedig nincs, vagy éppen kedvezőtlen. Hiszen semmilyen állampolgári jog nem érvényesülhet, ha nem jár együtt megfelelő kötelezettségekkel a hatóságok részéről, vagy ha az érintett jogalanyok, nem akarnak élni a kivívott jogokkal.

Az erdélyi magyar nyelvváltozat helyzetének kedvezőtlen tüneteit jelzi az anyanyelvi használati színtereinek korlátozottsága, a funkcionális és strukturális nyelvvesztés folyamatai közvetlenül összefüggésben vannak az állam nyelvpolitikájával, a nyelvi jogok kodifikációjával. A romániai rendszerváltozást követő pozitív nyelvi folyamatok ellenére, még számos tennivaló van a nyelvi jogok területén (Benő-Péntek 2002, CsernicskóPéntek 2011). Egyrészt mert az erdélyi magyarság az elmúlt években nem élt kellő mértékben a kedvező informális nyelvhasználati lehetőségekkel, másrészt mert a kisebbségi nyelvi jogok kodifikálásában még sok minden 
módosításra, javításra szorul ahhoz, hogy jelentősen megváltozzék a magyar nyelv jogi státusa Erdélyben. Úgy is mondhatjuk, hogy Románia jogállamiságának megerősödésétől függ, hogy folytatódnak-e az elmúlt két és fél évtized pozitív tendenciái, lévén, hogy a jogállamiság hagyományának hiánya, a nemzetállami rögeszme és az ezt kísérő hungarofóbia, valamint az asszimilációs folyamat különböző formája akadályozza az erdélyi magyar nyelv jogi helyzetének további javulását. Megjegyzendő ugyanakkor, hogy a többségi ellenkezésen túl mindenütt megnehezíti az anyanyelv hivatali használatát az a körülmény, hogy az erdélyi kisebbségi magyar nyelvhasználatból gyakorlatilag hiányzik a hivatali nyelvváltozat, annak egységes terminológiája, szövegtípusai, sajátos stiláris jegyei. Különösen a hivatali nyelv írott változata okoz gondot a magyarul egyébként jól beszélő hivatalnokoknak is: jegyzőkönyvek, határozatok megfogalmazása, típusnyomtatványok összeállítása, a hivatali levelezés stb. Ezen a nyelvi hiányon próbál segíteni a nyelvi tervezés az utóbbi években megjelentetett kétnyelvü közigazgatási és oktatásterminológiai szótárral (Fazakas 2002, Benő és mtsai 2004, Benő-Fazakas-Sárosi-Márdirosz 2009), típusnyomtatványok elkészítésével, folyamatos szaknyelvi konzultációval. A nyelvi tervezés valamennyi területén (státus-, korpusz- és oktatástervezésben) számos feladat hárul még az erdélyi magyarokra, sőt bizonyos, nyelvcserefolyamatokkal jellemezhető szórványrégiókban (Belső-Erdélyben, Dél-Erdélyben) alulról építkező nyelvi revitalizációs tevékenység is indokolt (Gál 2010). 



\section{A KONTAKTUSJELENSÉGEK TIPOLÓGIÁJA}

Mint ismeretes, a nyelvek érintkezése nem új jelenség; azóta van, amióta léteznek nyelvek, nyelvi közösségek. Ma már nyelvi univerzálénak (minden nyelvre érvényes megállapításnak) számít az a korábbi felismerés, hogy szükségszerüen minden nyelv érintkezik valamilyen más nyelvvel, hiszen a nyelvek, akárcsak a beszélőik, nem elszigetelten léteznek, hanem más nyelvek és népek szomszédságában, és ennek következményeként a kölcsönhatás elkerülhetetlen. A nyelvi érintkezés végső forrása a kétnyelvü beszélő, akinek - két nyelvi rendszert ismerve - lehetősége van arra, hogy két kód lehetőségei közül válasszon, amikor egy nyelven egy adott gondolatot ki akar fejezni. ${ }^{14}$ Ez a választás lehet tudatos (például valakinek más nyelvű szavait szó szerint idéző kódváltás) vagy pedig kevésbé tudatos, hiszen a kétnyelvű beszélők megnyilatkozásában olyan kontaktusjelenségek is érvényesülhetnek, amelyekről nekik nincs is tudomásuk. Az aktív kétnyelvü beszélő ugyanis két nyelvi rendszert müködtet akkor is, amikor látszólag neki csak az egyik nyelvre van szüksége. Az éppen nem használt nyelv ugyanis üzemmódban marad a háttérben, amint ez az aktív kétnyelvư beszélók interferencia-jelenségeiből is láthatók. ${ }^{15}$

A nyelvi érintkezéseket tanulmányozó kon tak tológia interdiszciplináris nyelvészeti terület, amely elsődlegesen a szociolingvisztika körébe sorolható, de felhasználja a pszicholingvisztika, kognitív nyelvészet, geolingvisztika, valamint a nyelvtörténet, etimológia, a lexikográfiai és lexikológia legújabb eredményeit is. Egy másik nyelv hatásának kitett nyelv(változat)

\footnotetext{
${ }^{14}$ Hermann Paul német nyelvész már 1886-ban megfogalmazta azt a gondolatot, hogy a szókölcsönzés valamilyen mértékű kétnyelvüséget feltételez (Haugen 1950).

15 „A két- vagy többnyelvű egyén sohasem tudja kikapcsolni a másik nyelvét vagy nyelveit, következésképpen a mentális lexikonban meglévő kapcsolatok átnyúlhatnak a nyelvek határain is" (Navracsics 2004: 419). L. még Grosjean 1995, Gósy 1999.
} 
mint rendszer és nyelvhasználat (a maga invariáns elemeivel együtt) a kontaktológia kutatási körébe tartozik.

A nyelvi érintkezés forrása a kétnyelvü egyén, de a nyelvi kontaktusjelenségek nem csak a kétnyelvűek beszédmódjában figyelhetők meg. Ha egy regionális nyelvváltozat beszélői körében a kétnyelvűség tömegméretü, akkor olyan kétnyelvű kontaktusváltozat alakul ki, amely az adott nyelvet egynyelvúként beszélők megnyilatkozásaiban is megnyilvánul. Gondoljunk csak az erdélyi magyar nyelvváltozatra. Az erdélyi magyar beszélők többsége magyar-román kétnyelvü, de Székelyföldön még akadnak olyan beszélők, akik többé-kevésbé egynyelvűeknek tekinthetők, mégis beszédükben észrevehetők kontaktusjelenségek. Az ő esetükben a román nyelvi hatás nem a többségi nemzet nyelvéből származik, hanem közvetlenül az erdélyi kisebbségi magyar nyelvváltozatban meghonosodott román eredetű nyelvi elemek hatásából. (Előfordulhat, hogy valaki Székelyudvarhelyen árdéjnak nevezi azt a zöldséget, amit a köznyelvi magyarban paprikának szoktak nevezni, jóllehet az illető személy esetleg egyáltalán nem tud románul.)

\section{Kontaktus, interferencia}

A nyelvi érintkezés (kontaktus) valamely nyelv hatásának megnyilvánulása egy másik nyelv használatában. Ez a hatás lehet hangtani, alaktani, szókészleti, mondattani vagy szemantikai természetű. Az idegen vagy másodnyelvi hatás megvalósulhat jelkölcsönzés formájában (ilyen a szó- vagy szószerkezet-kölcsönzés ) vagy valamilyen tulajd onságjegy, jelviszony (idegenszerü hangsúly, beszédtempó, szokatlan szórend) alkalmazásában. Mind a jelkölcsönzés, mind a szokatlan tulajdonságjegy alkalmazása az átvevő nyelv jelviszonyai között fordul elő, és többszöri használata szükségessé teszi a nyelvi kontextus által meghatározott szabályrendszerhez való igazodását, ami a meghonosodásának kedvez. Ez azt jelenti, hogy a kontaktusjelenség lehet egyszeri, alkalmi, egyetlen beszélőhöz kötött nyelvhasználati sajátság vagy pedig többszöri előfordulású, egy nyelvváltozatban általánosan elterjedt, esetleg normaértékű jelhasználati mód. Az előbbi esetben interferenciáról, az utóbbi esetben pedig kölcsön zésről beszélhetünk. A kölcsönzés ilyen értelemben az interferencia eredményének tekinthető.

Megjegyzendő, hogy az interferencia terminust általánosabban is használják a nyelvi érintkezés folyamata egészének a jelölésére az adott nyelvi jelenség elterjedtségétől függetlenül.

Az interferenciajelenség és a meghonosodás folyamatához kapcsolódó kölcsönzés együttes neve a kontaktusjelenség. 


\section{Az interferencia és a kölcsönzés társadalmi és nyelvi kontextusa}

Minél intenzívebb a nyelvi érintkezés, annál nagyobb számban, annál többféle interferenciával és kölcsönzéssel találkozunk. A nyelvi érintkezés erősségét, intenzitását olyan társadalmi tényezők határozzák meg, mint a kontaktus időtartama, az érintkező nyelvi közösségek számbeli aránya, a társadalmi-gazdasági dominancia, a nyelvi közösségek jogi státusa, illetve a kétnyelvüség aránya az adott nyelvi közösségek körében.

A kontaktus időtartama arra vonatkozik, hogy mióta érintkezik a két nyelv az adott földrajzi régióban. Nyilvánvaló, hogy a több évszázada létező kapcsolat több lehetőséget biztosít az érintkező nyelvek kölcsönhatására és a hatások integrálódására.

Az érintkező nyelvi közösségek mennyiségi viszonyán azt értjük, hogy a két nyelvi közösség beszélőinek a száma hogyan viszonyul egymáshoz. A számbeli fölényben levő nyelvi közösség általában kevesebbet kölcsönöz a kisebbségi csoporttól, mint fordítva.

A társadalmi-gazdasági dominancia is hatással van az érintkező nyelvek intenzitására, hiszen általában a gazdaságilag, technikailag fejlettebb közösség nyelvéből több elem kerül át a gazdaságilag kevésbé fejlett közösség nyelvébe, mint fordítva.

Az érintkező nyelvi közösségek jogi státusa arra utal, hogy a kontaktusban levő nyelvek használati szabályai miként vannak meghatározva a törvényekben és az adminisztratív intézkedésekben, illetve, hogy milyen nyelvhasználati lehetőségek adottak a különböző nyelvhasználati színtereken. Általában a jogfosztott, anyanyelvhasználatában korlátozott kisebbségi nyelvi közösséget erőteljesebben érinti a domináns csoport nyelve, mint fordítva.

A kétnyelvűség aránya a két érintkező nyelvi közösségben azért fontos szempont, mert ez erőteljesen befolyásolja az nyelvi kontaktus intenzitását, hiszen amelyik nyelvi közösségben természetesebb, elterjedtebb a kétnyelvưség, annak nyelvhasználatában több lesz az interferencia és a kontaktusjelenség (a 2001a: 15-21., Rot 1972: 49-50).

Egy másik nyelv hatása kezdetben egy szűkebb nyelvváltozatban, egy társadalmi vagy szakmai csoportban terjed el, és onnan kerül át más nagyobb, több beszélőt érintő nyelvváltozatokba (Melich 1933).

A kontaktusok intenzitását a nyelvi-grammatikai rendszerre gyakorolt hatás szempontjából is vizsgálják. Zybatow ilyen szempontból öt fokozatot különböztet meg: 1. alkalmi, 2. kissé intenzívebb, 3. intenzív, 4. erős és 5. igen erős fokozatot (idézi Nyomárkai 2004). Az alkalmi kontaktusok kizárólag nem alapszókincsbe tartozó szavak átvételét eredményezik. A 
kissé intenzívebb érintkezések elsősorban szintén lexikai kölcsönzésekben nyilvánulnak meg, de hozzájuk már a grammatikai struktúrát érintő jegyek is társulhatnak (pl. új szintaktikai funkciók kialakulása). Az intenzív kontaktus eredményei a viszonyjelölő elemek, toldalékok átvétele (prepozíciók, posztpozíciók, képzők), az erős, valamint az igen erős kulturális hatás a szókölcsönzések mellett morfoszintaktikai és szószerkezeti változásokat is eredményez.

A nyelvi érintkezések intenzitását, hatásának mértékét gyakran minősítik az időtartam szempontjából. A rövid ideig (néhány évtizedig tartó) kontaktus ideiglenes vagy instabil érintkezésnek tekinthető. Az orosz-magyar hatás például az 1989-es rendszerváltást megelőző néhány évtizedes korszakhoz köthető Magyarországon, és így az orosznak a magyar nyelvre gyakorolt hatása elenyészőnek tekinthető, már csak azért is, mert nem közvetlen népi érintkezésen alapult, hanem domináns idegen nyelvi hatásként értelmezhető. A hosszabb ideje, több évszázadok óta fennálló kontaktus permanens vagy stabil érintkezésnek tekinthető. Ilyenek magyar vonatkozásban a szlovák-magyar, német-magyar, szerb-magyar, román-magyar kapcsolatok.

Az érintkező nyelvek viszonya, az interferencia dinamikája az érintkező nyelvek geneológiai és tipológiai alkatától is függ. Az azonos nyelvcsaládba vagy nyelvtípusba tartozó nyelvek kapcsolatának kedvez a lexikai és grammatikai rendszer nagymértékü hasonlósága (pl. a franciaromán nyelvi érintkezés).

Az átadó és az átvevő nyelv viszonyát tekintve különbséget kell tenni a második nyelvből (környezeti nyelvből) származó és idegen nyelvből eredő kölcsönzés között. Ez a megkülönböztetés azért is szükségszerü, mert meghatározhatja a kölcsönzés módját, formáját és mértékét. Az idegen nyelvből származó kölcsönzés gyakran az írásbeliséggel függ össze, elsősorban a kulturális különbségeket érinti, és az átvett lexikai elemek számát és az érintkezés intenzitását tekintve, nem oly jelentős, mint a környezeti nyelvből kölcsönzés esetén, a népi érintkezésen alapuló kontaktusoknál (Kontra 1981).

Az érintkezés módját tekintve kétfajta nyelvi kontaktust lehet megkülönböztetni: közvetlen és közvetett érintkezést. Közvetlen nyelvi érintkezéskor a két népcsoport azonos földrajzi régióban él, és így nyelvi és kulturális kölcsönhatásuk természetes és rendszerint kétirányú, kölcsönös. A közvetett kölcsönzéskor az átadó és átvevő nyelvet beszélők nem élnek ugyanazon a területen, és a forrásnyelvi hatást ilyenkor valamelyik másik nyelv közvetítésével kerül az átvevő nyelv rendszerébe. Napjainkban az angol hatás számos európai nyelvben kimutatható, jóllehet nem beszélhetünk klasszikus értelemben vett nyelvi érintkezésről, ámde a 
tömeges nyelvtanulási láz, a tömegkommunikációs eszközök és a szórakoztatóipar (film, zene) angol nyelvü alkotásainak szüntelen sugárzása, a nemzetközi reklámvilág angol nyelvüsége, a globalizációs érdekek olyan helyzetet teremtenek, amely már-már vetekedik a klasszikus értelemben vett közvetlen érintkezéssel.

A közvetlen népi érintkezésben a nyelvi kapcsolat rendszerint kétirányú, kölcsönös, szim metrikus: mindkét érintkező nyelv hat egymásra. Ha azonban valamilyen történelmi tehertétel, előítélet vagy nyelvpolitikai tényező miatt az egyik nyelvközösség már nem tartja fontosnak a másik nyelv megtanulását, és a másik nyelvközösségben továbbra is természetes a kétnyelvűség, akkor ez az érintkezés egyoldalúvá, aszimmetrikussá válik. Tipikusan aszimmetrikus nyelvi érintkezéssé vált napjainkban a kisebbségi és többségi nyelvek kapcsolata a Kárpát-medencében (Péntek 2001: 138-139). A nemzetállami eszméken alapuló nyelvpolitika a kisebbségek számára kötelezően előírja a kisebbségi beszélők számára a többségi nyelv, az államnyelv ismeretét, és így - léthelyzetükből fakadóan, de ettől függetlenül is - a kisebbségi közösségek kétnyelvüvé válnak. A többségnek a kisebbségi régiókban sem kötelező ismernie a kisebbség nyelvét, sőt vannak olyan országok, ahol leértékelt, olykor megbélyegzett, stigmatizált nyelvként türik meg a kisebbségi nyelvváltozatokat. Az ilyen aszimmetrikus érintkezési helyzet megőrzését, konzerválását segíti elő a kisebbségi nyelvek jogilag alárendelt státusa, amelynek megváltoztatására rövid távon nincsenek kilátások. Az aszimmetrikus érintkezés ilyen értelemben összefüggésben van a kisebbségi nyelv funkcionális korlátozottságával, csökkent használati értékével (Péntek 2001: 46-47), ami még jobban felerősíti az államnyelv egyoldalú hatását.

\section{Idegen szó, kölcsönszó, jövevényszó}

A szókölcsönzés és szószerkezet-kölcsönzés tulajdonképpen egy olyan folyamatot jelöl, amely egy szűkebb nyelvváltozatból elterjedő idegen szótól a meghonosodott nyelvi elemig számos átvételt jelölhet az integrálódás mértéke szerint.

Ismert, hogy az idegen szó terminus azokra az átvételekre vonatkozik, amelyek bár elhelyezhetők az integrálódás folyamatának különböző szakaszain, és hangalakjuk is esetleg kisebb módosulásokat szenvedett, a beszélők nyelvérzéke számára továbbra is idegenszerünek tünnek. ${ }^{16}$ Idegen eredetükrôl leginkább hangalakjuk árulkodik, amely nem illeszkedik be az átvevő nyelv szavainak hagyományos hangszerkezetébe. A magyar

\footnotetext{
${ }^{16}$ Az idegen szó terminus megnevezései más nyelveken: ang. foreign words, n. Fremdwort, ol. parola straniera, fr. mot étranger.
} 
szavak hangszerkezetére, például, nem volt jellemző a szó eleji mássalhangzó-torlódás, és az ilyen hangszerkezettel meghonosodott átvételeket továbbra is idegennek, jelöltnek érzékelik a magyar nyelvi beszélő. Ilyenek, például, a proton, transzformátor, bróker, stigmatizál, trauma, psziché stb. ${ }^{17}$

A nemzetközi szavak, mint tudjuk, az idegen szóknak az a csoportja, amely számos nyelvben megtalálható, és amelyek összefüggésbe hozhatók a modern tudományos-technikai fejlődés vívmányaival: televízió, rádió, telefon, mobil, internet, e-mail stb.

Megjegyzendő, hogy a nemzetközi szavak elterjedésében az angol nyelvi hatásnak igen fontos szerepe van, ugyanis számos nemzetközi szó átvételében az angol közvetítő szerepet tölt be, abban az értelemben, hogy korábban már meghonosodott az angolban, majd az angol által terjed el más nyelvekbe világszerte. Ilyen például a taco és a tortilla (amelyek végső soron spanyol eredetűek), vagy a szusi, amely japán származású ételfajta neve, és amelynek elterjedésében az angol hatás mindenképpen számolni kell (Gottlieb 2006: 195).

A jövevényszó megnevezést kizárólag a meghonosodott lexikai átvételekre szokás használni. ${ }^{18}$ A jövevényszó hangalaki, morfológiai, esetleg jelentéstani módosuláson átment változások eredményeként vált alkalmassá arra, hogy az átvevő nyelvi rendszer jelöletlen tagjává váljon. A jövevényszó jelöletlensége abban mutatkozik meg, hogy a laikus anyanyelvi beszélő sokszor nem is sejti, hogy ezek a lexémák más nyelvből kerültek át az ő nyelvébe:
m. málna $<$ szl. malina
m. asztal $<$ szl. sztol
m. dús < ol.nyj. dúxe, duže (Zaicz 2006).

A meghonosodott jövevényszó jellemzője, hogy a megnőtt használati gyakorisága következtében képzős származékszóként és összetett szavak elemeként is megjelenik. Ezáltal a jövevényszó szócsaládot alakít ki az átvevő nyelv lexikai rendszerében, mint bármely régebbi átvevő nyelvi lexikai elem. A román eredetü, 'puliszka', 'lepény', 'kukorica' jelentésü málé szavunknak (< r. mălai) például a következő származékait jegyezték le az erdélyi nyelvjárási változatokban: málézik'málét eszik', málékodik 'bámészkodik', málézás 'gyermekjáték', málécska 'puliszkácska', málés 'puha, omló'. Íme, néhány ezzel a jövevényszóval alkotott összetételek közül: málébajusz 'a kukoricacső végéből kicsüngő bibeszál', máléfia 'fattyúhajtás a kukorica-

\footnotetext{
${ }^{17}$ Megjegyzendő, hogy a nyelvünkbe ilyen mássalhangzó-torlódásos hangszerkezettel beilleszkedett idegen szavak nagy számának köszönhetően a nyelvérzék nyitottabbá vált az ilyen hangzásszerkezetek iránt.

${ }^{18} \mathrm{~A}$ jövevényszó más nyelvű megnevezései: ang. loan word, n. Lehnwort, ol. prestito.
} 
tövén', málégyökér 'kukoricatő', máléliszt 'kukoricaliszt', málészájú 'gyámoltalan' (Márton-Péntek-Vöő 1977: 247-48).

A kölcsönelem meghonosodását jelzi, hogy az átvétel már nemcsak a kétnyelvűek megnyilatkozásában fordul elő, hanem az olyan beszélők szóhasználatában, akik nem vagy alig ismerik az átadó nyelvet (Király 1990: 48-55). A 90-es években például számos olyan angol nyelvi elem meghonosodott a magyar köznyelvben, amelyet ma már azok is használnak, akik nem tudnak angolul. Ezt példázzák a következő szavak: body, body-building, body-guard, dopping, bróker, e-mail, internet, komputer, shop, szponzor, topmodell, trend stb. Ilyen értelemben a kölcsönszó elterjedéséhez a kétnyelvüek és az egynyelvüek egyaránt hozzájárulnak.

A jövevényszó másik ismérve, hogy használata funkcionálisan indokolttá válik: lexikai hiányt tölt be az adott nyelvváltozatban, új jelentésbeli kategóriát hoz létre, stílusértékben vagy expresszivitásban különbözik a denotatív jelentésében ekvivalens átvevő nyelvi párjától. A meghonosodás folyamata a kölcsönelem funkcionalitásának megerősödését vagy kialakítását célozza.

\section{A kontaktusjelenségek tipológiája}

A szó- és szószerkezet-kölcsönzést abból a szempontból is lehet osztályozni, hogy a milyen módon valósul meg a kölcsönzés. Ha egy más nyelvi elem egyszerú átvételéről van szó, akkor közvetlen (direkt) kölcsönzésről beszélünk. A direkt kölcsönzés a jelkölcsönzés tipikus esete; tulajdonképpeni szókölcsönzésnek is tekinthető. Ennek eredményeként egy új morfémaértékű hangtest kerül át valamilyen nyelvváltozatba, ezért morfémikus átvételnek is nevezhető (Kontra 1981: 14).

A kölcsönzésnek van olyan módja is, amelynek következményeként nem jelenik meg egy újabb lexikai vagy morfológiai értékú hangsor az átvevő nyelvben, csupán valamilyen idegen mintára történő jelentésmódosulást tapasztalunk. Az ilyen kontaktológiai jelenségeket közvetett (indirekt) kölcsönzésnek nevezzük (Kontra 1981: 15, Bartha 1993: 28-29, Lanstyák 2006).

Külön kategóriaként tartandók számon a hibridkölcsönzések (amelyekben a közvetlen és a közvetett nyelvi hatás egyaránt érvényesül), valamint a kódváltás, mivel ez nem sorolható a hagyományos értelemben vett átvételek kategóriájába, lévén hogy a kódváltásnál nincs szó arról, hogy meghonosodnak valamilyen nyelvi elemek a jelenség érvényesülésekor. 


\subsection{A közvetlen (direkt) kölcsönzés formái}

A közvetlen kölcsönzés körébe sorolható a tulajdonképpeni (köznévi funkciójú) lexikai átvétel, a tulajdonnév-kölcsönzés, a betúszókölcsönzés, a hangalakkölcsönzés és a visszakölcsönzés.

\subsubsection{Tulajdonképpeni vagy morfémakölcsönzés}

A tulajdonképpeni szókölcsönzés egy új szóval gazdagítja az átvevő nyelvváltozatot, amennyiben az átvett nyelvi elem meghonosodik az adott nyelvváltozatban, regiszterben. Az átadó nyelv kérdése nemritkán problematikus lehet, mivel a kölcsönzések többirányúak és összetettek lehetnek. Előfordulhat például, hogy egy végső soron latin vagy görög eredetű szó valamely közvetítő nyelv által kerül az átvevő nyelvbe. A tipizál igénk, például, nem közvetlenül a latinból származik, a typus főnévből, hanem az azonos jelentésű német typisieren igéből (Tótfalusi 2008). Hasonló módon az erdélyi magyarban a penndrive vagy usb nevü adathordozót sticknek is nevezik, ami a magyarországi beszélőknél nemigen fordul elő. Ez az angol eredetű szó lehetséges, hogy a román nyelv közvetítésével került bizonyos erdélyi magyar nyelvváltozatokba, mivel a románban ez a megnevezés általánosan elterjedt, gyakori megnevezése a kisméretü adathordozónak. Ha ez így van, akkor e szó tekintetében a román az elsődleges átadó nyelv, az angol pedig a másodlagos átadó nyelv.

A közvetlen (direkt) kölcsönzés eredményeként megjelenő kölcsönelem hangalakja, mint köztudott, a meghonosodás folyamatában rendszerint fonológiai változásokon megy át, mintegy hozzáigazodik az átadó nyelv lexikai elemeinek szokásos hangszerkezetéhez. İme, néhány ilyen jellegú példa a magyarba átkerült német eredetű jövevényszavak csoportjából: kulisse > kulissza; frappant > frappáns; blamieren > blamál; zwirne > cérna.

$\mathrm{Az}$ átvett kölcsönelemek hangalakja egybeeshet az átvevő nyelv valamely szavának hangsorával, olyan módon, hogy a jelentésük között nincs fogalmi érintkezés. Ebben az esetben kölcsönhomonimáról beszélhetünk (Lanstyák 2006: 92). A szakirodalomban hom of on oknak is nevezik az azonos alakú, denotatív jelentésükben egymáshoz nem kapcsolódó szavakat. Ilyen kölcsönhomonimának tekinthetố a vajdasági, a muravidéki és a horvátországi magyar nyelvváltozatban megjelenő, 'vörösborból és kólából álló italkeverék' jelentésű bambusz szó, vagy a napidíj értelmü diéta a felvidéki magyarok beszédében. (Az erdélyi adatokat l. a IV. fejezetben). 
A kölcsönzés eredményeként olyan elemek is átkerülhetnek bizonyos regiszterekbe, amelyeknek van hangalaki és jelentésbeli párja az átvevő standard változatában, azaz lényegében alakváltozatok, de morfológiai szerkezetük különböző lehet. Ilyen kölcsönelemek az alábbiak: bufet 'falatozó, talponálló' (Er, Fv, Ka) ${ }^{19}$ - közm. büfé 'ua.'; dekrét (Er, Fv, Ôv) 'határozatot tartalmazó irat' - közm. dekrétum 'ua.'; szimpatizőr (Va) 'rokonszenvezö' - közm. szimpatizáns 'ua.'. Az ilyen lexikai elemeket alaki kölcsönszavaknak szokás tekinteni.

A kölcsönszavak meghonosodását jelzi, hogy a lexikai átvételnek képzéssel, szóösszetétellel szócsaládja alakul ki, azaz újabb szavak jönnek létre az alakilag egyszerü jövevényszóból. A kölcsönszóból belső szóteremtő eljárással létrehozott lexikai elemeket másodlagos kölcsönszóknak tekinthetjük, amint az alábbi, külső régiókból származó adatok ezt szemléltetik: bágerozik (Fv) 'kotrógéppel dolgozik' ( $\leftarrow$ báger 'kotrógép'); burekozó (Va, Hv) 'vendéglátóipari egység, ahol burek fogyasztható' ( $\leftarrow$ Va, Hv burek 'hússal, túróval, almával töltött sült tésztaféle'); firmás (Mv) 'márkás' $(\leftarrow$ firma 'gyári védjegy, márka'), szemiscipő ( $\mathrm{Fv}, \mathrm{Mv})$ 'velúrbőr cipö' $(\leftarrow \mathrm{Fv}$, Mv szemis 'velúrbőr').

\subsubsection{Tulajdonnév-kölcsönzés}

A nyelvi érintkezések következtében nemcsak köznevek, hanem tulajdonnevek (főleg földrajzi és személynevek) is kölcsönzésre kerülhetnek. A tulajdonneveknek, akárcsak a közneveknek a meghonosodás folyamatában módosul a hangalakjuk, és e módosulás következtében elhalványulhat az eredeti név szerkezeti motiváltsága. Az angol vagy a német nyelvből több ilyen adatot idézhetünk a földrajzi nevek eredeti jelentésbeli motiváltságának megszünésére a meghonosodással együtt járó hangalaki változásoknak köszönhetően:

ang. New Zealand < holl. Nieuw Zeeland ('új tenger föld')

ang. Canberra < Nganbirra (az ausztráliai bennszülött nyelvből származó név jelentése: 'találkozó hely')

ném. Dresden < szl. Drezdzany (<drenzga'erdő') (Hough 2006: 616).

${ }^{19} \mathrm{Az}$ idézett adatokban előforduló rövidítések a Termini-adatbázis gyakorlatát követi. Ezek a rövidítések a következők: 1. A nyelvi régiók felségjelzései: Er: Erdély, Fv: Felvidék, Va: Vajdaság, Ka: Kárpátalja, Hv: Horvátország, Mv: Muravidék (= Szlovénia magyarlakta területei); 2. A nyelvekre vonatkozó rövidítések: ang: angol, m: magyar, ném: német, r: román, szl: szláv, szlk: szlovák. 


\subsubsection{Betüszókölcsönzés}

A betűszókölcsönzés a direkt kölcsönzésnek egy sajátos formája, amely abban különbözik a tulajdonképpeni kölcsönzéstől, hogy az etimon az átadó nyelvben is több szó rövidítéséből keletkezett, így gazdag információtartalom és konkrétabb jelentésvonatkozás jellemzi. Különösen a szaknyelvekben divatos az idegen (föleg angol) eredetü betüszó alkalmazása: AIDS (angol eredetü), SIDA (francia eredetü), GSM (< ang. Global System for Mobile Communication), HDD (Hard Disc) RAM (< ang. Random Acces Memory).

Íme, néhány román és angol eredetü példa a romániai magyar nyelvváltozatból: PhD (< ang. PhD: Philology Doctor), tévéá (TVA) (< r. tva: taxa de valoare adăugată) 'hozzáadott értékadó, áfa', Csekk 'takarékpénztár' (<r. CEC: Casa de Economii şi Consemnaţiuni).

\subsubsection{A hangalakkölcsönzés}

A direkt kölcsönzés eredményeként olyan hangalak is bekerülhet az átvevő nyelv valamely változatának szókincsébe, amelynek már van egy hasonló hangalakú és hasonló (vagy azonos) jelentésü párja (pl. kontakt kontaktus). Ennek a nyelvi jelenségnek hangalakkölcsönzés a neve. A hangalakkölcsönzés így elsősorban azzal magyarázható, hogy a kétnyelvű beszélőben a két ismert nyelv hasonló hangalakú (homofon) lexémái erőteljes érintkezésben vannak, egyik felidézheti a másikat, még az egynyelvü közlésben is. Ha egy román-magyar kétnyelvü beszélő megnyilatkozása így hangzik: A szomszédomnak infarktja volt, akkor az infarkt hangalak megjelenésének két oka is lehet. Az egyik indítéka az, hogy az infarktus - infarkt homofonpárok közül az utóbbit gyakrabban hallja a környezetében az egyik vagy másik nyelvü kommunikációban, és így ez a hangalak könnyebben felidéződik, mivel erősebb asszociációkkal kötődik az adott fogalomhoz. Az adott hangalak akkor is megjelenhet, ha a beszélő mentális lexikonából hiányzik a normatív alakváltozat (infarktus). Ilyenkor a beszélö olyan nyelvváltozattal él, amely kontaktus nyelvváltozatként minősíthető, mivel egy másik nyelv erőteljes hatását jelzi. Ebben az esetben nem valamilyen egyszeri, egyedi interferenciával van dolgunk, hanem egy adott nyelvváltozatban (például egy erdélyi magyar nem standard változatban) meghonosodott kontaktusjelenséggel.

A Magyarországgal szomszédos államokban beszélt kisebbségi magyar nyelvváltozatok nem standard használatában megfigyelhető a latin, görög eredetü és más nemzetközi jellegű szavak hangalakjában a többségi nyelv hatása. Ez megnyilvánul az eredeti toldalékok elmaradásában (pl. 
katalóg, infarkt, internát, referát - szemben a standard katalógus, infarktus, internátus, referátum hangalakkal), és a végződések fölcserélése a többségi nyelvi végződéssel: fakulta (m. sz. fakultás), olimpiáda (m. sz. olimpia), szkleróza (m. szklerózis) (Lanstyák 2002: 196).

\subsubsection{Visszakölcsönzés}

A visszakölcsönzésnek nevezett kontaktológiai jelenség bizonyos fajtája is a hangalakkölcsönzéshez tartozik. A visszakölcsönzés megnevezés tulajdonképpen arra a kontaktológiai jelenségre utal, amikor egy átadó nyelvből származó hangalak, az átvevő nyelvi módosult formája szerint újra visszakerül az átadó nyelvbe vagy nyelvváltozatba. Így például a francia eredetű le boeu az angolban beef formában terjedt el, majd a beefsteak szószerkezetben újra átkerült a franciába le biftek alakban: fr. le boeu > ang. beef; ang. beefsteak > fr. le biftek.

Ha jelentésmódosulás nélkül illeszkedett be a hangalak az átvevő nyelvbe, akkor joggal sorolhatjuk a visszakölcsönzést a hangalakkölcsönzés sorába. Ám a visszakölcsönzésnek gyakoribbnak látszik az a formája, amikor a kölcsönszó jelentése is módosul a beilleszkedés folyamatában:

m. bulcsú, búcsú 'mise, zarándoklat' > r. bulciu 'nagyvásár' > m. cs. bulcsu 'ua.'

Ilyenkor nemcsak hangalakkölcsönzésröl van szó, hiszen az átadó nyelvbe visszakerülő lexikális egység hangalakban is, jelentésben is különbözik az eredeti etimontól, és így új lexikális egységként illeszkedik az átvevő nyelvbe. A beszélők nincsenek is tudatában a kétszeres kölcsönzésnek, és így a visszakölcsönzésnek ez a formája a tulajdonképpeni vagy morfémakölcsönzéshez áll közelebb, és nem a hangalakkölcsönzéshez. ${ }^{20}$

\subsection{A közvetett (indirekt) kölcsönzés és nyelvi hatás formái}

A közvetlen kölcsönzés megnyilvánulhat jelentéskölcsönzésben, tükörszavak és tükörkifejezések használatában és a stíluskölcsönzésben. ${ }^{21}$ Ám az átadó nyelv közvetett hatása nemcsak a lexikai és grammatikai kölcsönzésében mutatkozhat meg, hanem az idegen elem tudatos kerülé-

\footnotetext{
${ }^{20}$ A visszakölcsönzés metaforikusan értendő, hiszen ez a megnevezés a nyelvész nézőpontját tükrözi, akinek ismeretei vannak a szavak eredetéről és vándorlásáról, a beszélők aligha sejtik a folyamat eredetét és irányát.

${ }^{21} \mathrm{Az}$ indirekt kölcsönzés angol neve loanshift. A loanword direkt kölcsönzésre utal.
} 
sében, hiperpurizmusban, illetve bizonyos nyelvi formák eltérő gyakoriságában, relatív kontaktusjelenségben is.

\subsubsection{Jelentéskölcsönzés}

Jelentéskölcsönzés tekinthető az a jelenség, amelynek eredményeként egy nyelvi jel egy vele ekvivalensnek minősített más nyelvi jel többértelmü jelentésszerkezetének mintájára lesz használatos. Például:

r. orar 1. órarend; 2 nyitvatartás $>$ r. m. órarend 'nyitvartartás'

szlk. šroký 1. bő; 2. széles > szlk. m. széles 'bő' (Lanstyák 1998: 44).

A jelentéskölcsönzés következménye nemcsak abban áll, hogy valamely szó új jelentéssel gazdagodik, hanem a hatása új grammatikai viszonyokat is teremthet. Jó példa erre a románba a locui 'lakni' jelentésmódosulása a francia habiter hatására. A románban az ige kizárólag tárgyatlan, intranzitív grammatikai jelentésben volt használatos, és a francia hatás eredményeként meghonosodott a tárgyas (tranzitív) grammatikai jelentése is: El locuiește în palat (intranzitív), El locuieşte un măreț palat de vară (V. Alecsandri) (tranzitív). ${ }^{22}$

Ez a jelenség is mutatja, hogy a lexikai-szemantikai változások a grammatikai viszonyokat is érinthetik, másrészt arra is utal, hogy a jelentéskölcsönzés és a tükörkifejezés elkülönítése nem mindig egyértelmű, mivel ilyen esetben tulajdonképpen egy szószerkezetbeli viszony módosul, és nemcsak egy szó belső jelentésszerkezete.

\subsubsection{Tükörszavak, tükörkifejezések}

Tü körszavaknak tekintjük egy más nyelvi minta alapján fordítással létrejött származék- és összetett szavakat. (Ha egyszerű szavaknál hasonló jelenséget tapasztalunk, akkor nem tükörszókról, hanem jelentéskölcsönzésről beszélünk.) Íme, néhány példa a tükörszóra különböző nyelvekből és nyelvváltozatokból:

fr. entrevoir > r. întrevedea 'előrelátni' (Hristea 1984: 100)

r. bilet de trimitere $>$ r. m. küldốpapír 'beutaló'

ang. movie house > am. m. moziház 'mozi' (Bartha 1993: 30).

\footnotetext{
${ }^{22}$ A kontaktológiai folyamatok összetettségét jelzi az a tény, hogy a r. locui ige a magyar lakni igéből származik (DEX). Vagyis egy magyar eredetű jövevényszó jelentésszerkezete francia hatásra módosult a románban.
} 
Az összetett szót alkotó tükörfordítások igekötős szerkezeteket is eredményezhetnek, ami tovább gazdagítja az átvevő nyelv igekötőrendszerét. Az alábbi német eredetü kölcsönelemek szemléltetik ezt a folyamatot: $n$. abreagieren $>$ m. lereagál; n. Antrieb > m. meghajtás.

Egyetlen nyelvből származó lexikai modell számos nyelvben felhasználásra kerülhet. Különösen, ha újabb tudományos-technikai kifejezésről van szó. Az amerikai angolban használt skyscraper például számos európai nyelvben megjelent tükörszóként: $\mathrm{m}$. felhókarcoló, n. Wolkenkratzer, fr. gratte-ciel, sp. Rascacielos (Haugen 1950: 215). Ezt azt jelzi, hogy nemcsak vándorszókkal kell számolni, hanem vándortükörszókkal is.

A magyarban több metaforikus jelentésű igekötős ige és számos összetett szó német mintára keletkezett (Kiss-Pusztai 2003: 191). Ilyen például a belát $(<\mathrm{n}$. Einsehen), kiértékel (n. < auswerten), álláspont $(<\mathrm{n}$. Standpunkt), állatkert $(<\mathrm{n}$. Tiergarten), jogerős $(<\mathrm{n}$. Rechtskräftig).

A tükörkifejezések fordítással keletkezett két vagy több szabad morfémából álló szószerkezetek, amelyek az átadó nyelvi szerkezettel a szerkezetet alkotó elemek és az összjelentés tekintetében is megegyeznek:

r. medic de famile > r. m. családi orvos 'háziorvos'

r. a da bună ziua > r. m. (n.st.) jó napot ad 'köszön'

Amint látható, a tükörkifejezések szószerinti fordítások az átadó nyelvből, mivel az ilyen módon létrejött állandósult szószerkezet az alkotóelemek, a szavak jelentésének a szintjén is azonos a forrásnyelvi lexikai modellel.

\subsubsection{Közvetett frazémakölcsönzések, vándorszólások, jövevényszólások}

A szólások és közmondások kölcsönzése igen elterjedt a legkülönbözőbb nyelvi érintkezéseknél. Sőt, bizonyos frazémaegységek, a nemzetközi szókhoz hasonlóan számos nyelvbe bekerülnek fordítás révén. Az ilyeneket vánd or szólás soknak nevezik. A legtöbbször igen nehéz kideríteni, hogy a számos nyelvben fellelhető frazémáknak és frazémaváltozatoknak melyik nyelv a forrása. Nyelvünk olyan szólásainak, mint: elöre iszik a medve bőrére; kígyót melenget a keblén, a legtöbb európai nyelvben van ekvivalens párja.

Az ilyen jellegü, az átvevő nyelvben teljes mértékben meghonosodott, több nyelvváltozatban is jelentkező szólásokat jövevény szólás soknak nevezzük. 
A fentebb idézett magyar nyelvi szólásokhoz hasonlóan, több más, nyelvünkben használt közvetett frazémakölcsönzésnél pontosan megnevezhető az átadó nyelv. Olyan szólásaink, mint: ritka, mint a fehér holló; kákán is csomót keres; nesze semmi, fogd meg jól - bizonyíthatóan a latinból származnak (O. Nagy 1988: 31).

\subsubsection{Stíluskölcsönzés}

Egy adott nyelvváltozatban bizonyos lexikai elemek stílusértéke egy másik nyelv hatására módosulhat a normatív nyelvváltozathoz viszonyítva. A líceum szó például az erdélyi regionális köznyelvben általánosan elterjedt, formális és informális helyzetben egyaránt használatos, és a legkülönbözőbb társadalmi és területi nyelvváltozatokban föllelhető. A magyarországi standardban azonban régiesnek minősül (Bakos 1989: 495). A románban a liceu szintén semleges stilisztikai értékét tekintve, és így az erdélyi regionális köznyelvben a román eredetű líceum szó stílusértéke is meghonosodott abban az értelemben, hogy ugyanolyan módon használatos, mint a románban. Az ilyen kontaktológiai jelenség stíluskölcsönzésnek minősíthető. Ugyanezt tapasztaljuk az erdélyi és a felvidéki inspektor szónál, amely a standard magyarban régiesnek tekinthetö, az erdélyi és a felvidéki magyar nyelvváltozatokban pedig kollokviális, sőt olykor formális kontextusokban is előfordul (Lanstyák 2002: 99-100). A stílusértékbeli különbség a gyakorisági érték megváltozásával van összefüggésben, hiszen egy régiesnek minősített szó ritkábban fordul elő, mint egy olyan, amely nemcsak a standardban, hanem számos regiszterben megtalálható.

\subsubsection{Hiperpurizmus}

Ugyancsak a közvetett kontaktusjelenségek sorába sorolható az iskolázottabb magyar kisebbségi beszélők nyelvhasználatában megfigyelhető hiperpurizmus. Ez abban nyilvánul meg, hogy a kontaktushelyzetben élő beszélők a lehető legnagyobb mértékben kerülni igyekszenek idegen szavakat. Ez egyfajta tudatos védekezés a többségi nyelv hatásával szemben. Ez a viszonyulás nemcsak a magyarabb változat preferálását jelenti, hanem néha saját alkotású szerkezetek is kialakulnak. Ezt példázzák a következő adatok a szlovákiai magyar sajtóból: behozatali áru 'importáru, importcikk', félellátás 'félpanziós ellátás', kockázatos faktor 'rizikófaktor', tevékeny védekezés 'aktív védekezés' (Lanstyák 2002: 90). 


\subsubsection{Relatív kontaktusjelenségek}

Egy másik nyelv hatása bizonyos nyelvhasználati sajátosságok gyakoriságának változásában is megmutatkozik. Ilyen esetekben a kétnyelvü beszélők megnyilatkozásában nem fordulnak elő olyan nyelvi elemek, amelyek az egynyelvűek beszédében ne lennének meg, csupán ezeknek a gyakorisága eltérő. Az ilyen jellegű másodnyelvi hatást rela tív kontaktusjelenségnek nevezhetjük.

Ismert, hogy a magyar nyelv szintetikusabb jellegű a szláv és a neolatin nyelvekhez képest, amelyekben erőteljesebbek az analitikus vonások. Egyes magyar nyelvváltozatokban a környezeti nyelvek hatása abban is megnyilvánulhat, hogy a magyar bizonyos kisebbségi nyelvváltozataiban az analitikus szerkezetek nagyobb gyakorisággal jelentkeznek az anyaországi beszélőkhöz viszonyítva. Az 1995-96-os szociolingvisztikai felmérések (A Kontra Miklós által vezetett, hét országra kiterjedő kutatásokra gondolok) azt jelzik, hogy a megkérdezett, kisebbségi helyzetben élő magyar beszélők gyakrabban élnek az analitikus szerkezetekkel, mint a magyarországi adatközlők (Göncz 1999: 173-75). A megkérdezetteknek olyan szintetikus és analitikus nyelvi változók közül kellett választaniuk a természetesség, a megszokottság, a jól formáltság tekintetében, mint a következők: tagdíj - tagsági díj; buszozás - utazás busszal; hegedül - hegedün játszik; szépitkezik - szépiti magát stb. Minden régióban előfordult mindkét nyelvi változó, de a megkérdezett, kontaktushelyzetben élő kisebbségi beszélők átlagosan gyakrabban éltek az analitikus változókkal, mint a magyarországi adatközlők. Mivel ez a különbség statisztikai értelemben szignifikánsnak minősíthető, minden bizonnyal helyes az a magyarázat, amely a kétnyelvüségi helyzetre, az államnyelv közvetett hatására mutat.

Az ilyen kontaktusjelenségek az indirekt kölcsönzésnél is nehezebben észrevehetők, mivel az egynyelvűek beszédében is előfordul, és a különbségek közvetlenül nem észlelhetők, csak kvantitatív szociolingvisztikai vizsgálatokkal mutathatók ki. Ezek a jelenségek az egynyelvú nyelvváltozatokban teljesen hiányzó, abszolút kontaktusjelenségekhez képest relatív kontaktus jelenségek (Lanstyák 2002: 93). A relatív kontaktusjelenségek abban különböznek az indirekt kölcsönzéstől, hogy ezeknek nincs egyetlen átadó nyelvi modelljük, nem mutatható ki, hogy konkrétan milyen nyelvi jel vagy jelsor hatásra jött létre az átvevő nyelvben az adott nyelvi forma.

A relatív kontaktusjelenségek lehetnek morféma-, szószerkezeti vagy mondatszintűek, hiszen a nyelvi változók a legkülönbözőbb grammatikai szerkezetben megjelenhetnek. 
Morfémaszintű relatív kontaktusjelenségként tartható számon a kicsinyítő képzők gyakoribb használata a kisebbségi magyar nyelvváltozatokban. Az 1995-96-os szociolingvisztikai felmérés szerint a megkérdezett kisebbségi magyar beszélők gyakrabban éltek a kicsinyítő képzős változókkal, mint a magyarországi adatközlők, ami valószínúleg a többségi nyelv közvetett hatásával magyarázható, mivel a szláv és a neolatin nyelvekben a kicsinyítő képzők használata gyakoribb, mint a magyarban (Göncz 1999: 180-81.).

Szószerkezeti relatív kontaktusjelenségként értelmezheto a „fölösleges", redundáns névmások eltérő használata a különböző magyar nyelvváltozatokban. A normatív magyar nyelvváltozatban a tárgyas ragozású ige és névmást tartalmazó szószerkezet esetében (pl. látlak téged) a névmás gyakran elmarad, mivel az igében már jelen van a névmás által hordozott jelentés. Természetesen, más magyar nyelvváltozatokban a "fölösleges" névmások előfordulnak, így önmagában a jelenség nem kontaktusjelenség. Ám a kisebbségi magyar adatközlők nyelvhasználatában a redundáns névmások használata átlagosan nagyobb gyakoriságot mutatott, mint a magyarországiak opcióiban, és így a jelenség értelmezésében kontaktológiai szempontok is felmerülnek.

Mondattani szinten is kimutatható a közvetett és relatív nyelvi hatás. Ilyen jelenség a predikatív és jelzős szerkezetekben jelentkező számbeli egyeztetés eltérő formája a kontaktushelyzetben és a Magyarországon élő adatközlők válaszaiban. Ismert, hogy a standard magyar nyelvváltozatban az egyes szám használata gyakoribb, mint az indoeurópai nyelvekben: páros testrészek nevei és a sok hasonló egyedből álló dolgok rendszerint egyes számban fordulnak elő: fáj a szeme (nem fájnak a szemei), almát vásárolt (nem almákat vásárolt). A magyar standardban az alany-állítmány egyeztetésnél gyakoribb az egyes számú egyeztetés, mint az indoeurópai nyelvekben ( $\mathrm{pl}$. Piroska és Jolán elszaladt - nem elszaladtak.) Az említett szociolingvisztikai vizsgálatban olyan kérdések is voltak, amelyek a számbeli egyeztetésre irányultak: pl. „A mai gyerekek attól válnak önzőkkélönzővé, hogy mindent megkapnak. - Melyik természetesebb?" Az eredmények szerint a kontaktushelyzetben élő adatközlők gyakrabban választották a többes számú opciót, mint a magyarországi adatközlők, ami arra enged következtetni, hogy a jelenség eltérő arányú érvényesülése a többségi nyelv hatását is jelezheti.

Ugyancsak a relatív kontaktusjelenségek sorába sorolandók a nyelvi bizony talanság különböző formái: beszédtempó-lassulás, nagyobb mértékben érvényesülő hangsúlyeltolódás, hezitációk, gyakoribb szótévesztések, lassúbb fogalmazás (Lanstyák 2002: 90). Ezek azért tartoznak a relatív kontaktusjelenségek sorába, mert ezekben az esetekben nem mu- 
tatható ki egy konkrét átadó nyelvi jel vagy jelsor hatása, hanem az átadó nyelv gyakran érvényesülő általános sajátosságai és ennek következményei érvényesülnek a kontaktushelyzetben élő kétnyelvű beszélő megnyilatkozásaiban.

\subsection{Hibrid kölcsönszavak és hibrid szerkezetek}

A direkt és indirekt kölcsönzések mellett meg kell különböztetnünk hibrid kölcsönszavakat és szerkezeteket is ${ }_{,}{ }^{23}$ mivel az ilyen jellegü átvételekben a direkt és indirekt kölcsönzési mód keveredhet: megjelenik egy tulajdonképpeni kölcsönszó és ezzel együtt, ugyanabban a szószerkezetben egy másik nyelvi minta alapján tükörfordítással létre jött új szójelentés:

r. a face intabulare > r. m. (n.st.) intabulárét csinál 'telekkönyvez'

Összetett szavak szintjén is megjelenhetnek hibridszerkezetek. Mivel az ilyen szószerkezetek szintén egy más nyelvi modell követésével alakultak ki, a közvetlen és a közvetett kölcsönzési mód keveredésének tekinthetjük őket, még akkor is, ha a szerkezet lefordított szava az adott jelentésben is normatív használatú: pl. a szlovákiai magyar nyelvváltozatban: víberliszt 'rétesliszt' (szlk. vyberova múka), konyhalinka 'konyhaszekrény' (kuchinska linka) (Lanstyák 1998: 42). Az amerikai magyarok nyelvhasználatában a következő hibridszerkezeteket jegyezték le: bördnév 'keresztnév' (ang. birdname), frantszoba (ang. front-room), horszlégy 'lóbögöly' (horsefly), nörszlány (ang. nurse girl), nyaktáj 'nyakkendö' (necktie) (Bartha 1993: 29). ${ }^{24}$

A hibrid kölcsönszavak megjelenése egyáltalán nem új jelenség, hiszen nyelvünkben már az ómagyar korban alakultak ki ilyen módon összetételek, többek között német és olasz mintára:

ném. galitzen Stein $>$ m. gálickő

ném. Hofmeister $>\mathrm{m}$. hopmester

ol. pom granat > m. gránátalma (Zaicz 2006).

Összegzésként megállapítható, hogy a nyelvi hatás formái igen változatosak. A nyilvánvaló, szembetűnő kimondottan lexikai jellegü idegen szó használatától a rejtettebb természetű grammatikai relatív kontaktusjelenségekig terjed. Érthető módon ez utóbbi jelenségkör kevésbé feltárt a nyelvi érintkezések vizsgálatában.

\footnotetext{
${ }^{23}$ ang. loan hybrid

${ }^{24} \mathrm{~A}$ mai magyarországi nyelvhasználatban is kimutathatók angol hatással magyarázható hibridszavak, például a cégek és szolgáltatások megnevezésében: drinkbár, jégtrade, szoftvercég.
} 



\section{KÖZVETLEN (DIREKT) KÖLCSÖNZÉSEK}

Mint ismert, közvetlen (direkt) lexikai átvételek új hangalakokkal gyarapítják az átvevő nyelv vagy nyelvváltozat szókészletét. Az erdélyi magyar nyelvváltozatokban használt, román és más nyelvből származó kölcsönszavakat többféle szempontból lehet osztályozni: 1. a meghonosodás időszakát vizsgálva, azaz történetiségükből kiindulva, 2. különböző nyelvváltozatokba és regiszterekbe való tartozásuk szerint, 3. fogalomkörük alapján, 4. expresszivitásuk, 5. stílusváltozati hovatartozásuk, illetve 6. az elterjedtségük, meghonosodottságuk szerint. Mivel Bakos Ferenc az 1982-ben megjelent monográfiájában következetesen alkalmazza a diakrón szempontot a román eredetű szókészletünk vizsgálatában, és mivel ennek a dolgozatnak a tárgya a mai erdélyi magyar nyelvváltozatok kontaktusjelenségei, a kölcsönszavak történetiségére nem térek ki külön, hanem inkább a többi felsorolt szempontot érvényesítem a kontaktusjelenségek bemutatásakor.

$\mathrm{Az}$ erdélyi magyar nyelvváltozatok kontaktusjelenségeinek legnagyobb része az államnyelvi státusú románból származik, lévén, hogy az erdélyi magyar anyanyelvűeknek kb. $90 \%$-a beszéli ezt a nyelvet, amint erről szó volt a szociolingvisztikai hátteret bemutató második fejezetben. Természetesen, beszélhetünk angol nyelvi hatásról is, de ez nagyon kismértékü a román hatáshoz képest, és bizonyos nyelvváltozatokat érint erőteljesebben. 


\section{Közvetlen kölcsönzések a nyelvváltozatok, regiszterek szempontjából}

A kölcsönelemeket minősíthetjük a dialektusbeli és a regiszterbeli hovatartozás szempontjából. A dialektusbeli és a regiszterbeli jelenségek kategorizálásánál a Termini-szótár terminusait használom, amelyek Lanstyák István irányításával készültek a Termini-kutatóhálózat keretében, és minősítési alapként szolgál az adattár lexikai elemeinek tipologizálásánál. ${ }^{25}$ Ezenkívül az erdélyi lexikális elemek stílusminősítésénél a szerkesztők figyelembe vették az RK (Márton-Péntek-Vöő 1977) stílus- és regiszterbeli besorolásait.

A dialektusbeli minősítések kategóriái a következők: általános, népies, idegenes, tájnyelvi, gyermeknyelvi, iskolázott. Az általános kategória olyan kölcsönszavakra utal, amelyeket különböző iskolázottságú személyek egyaránt használnak. A Termini lexikai adatbázisban a következő elemek szerepelnek ezzel a minősítéssel: aragáz 'propánbután-gáz'; buletin 'személyi igazolvány'; (el)hurbol 'elnyü, elvisel'; halva 'általában napraforgómagból, cukor felhasználásával készült édesség'; kaláka 'népi társas munka, amelyet szívességből vagy kölcsönösségi alapon végeznek; társas munka', karióka 'filctoll'; kazettofon 'kazettás magnetofon'; kukkra 'egyenesen, magasan fölfelé, magasra'; kulturista 'testépítő, body-builder'; kulturizmus ' testépítés, body-building', leblokál' leáll, üzemzavar miatt hirtelen megáll; nem müködik'; licencvizsga 'záróvizsga, államvizsga'; maxi-taxi 'helyi közszállításban használt kisbusz'; média 'átlagos osztályzat'; miccs 'darált húsból kolbász alakúra összegyúrt, roston sütött ételféleség'; miccsezés 'miccssütés és -evés', moketta 'padlószőnyeg; szőnyegpadló'; motorina 'gázolaj, nyersolaj', murok'sárgarépa' (ez szláv eredetű kölcsönszó); murokfózelék'sárgarépa-főzelék'; mutuj 'ügyetlen', 'buta', mutujkodik'ügyetlenkedik, butáskodik'; oltyán 'Olténiában (a Déli-Kárpátok és az Al-Duna között) élö, román nyelvü népcsoport'; plasztelin 'gyurma', perfúzió 'infúzió', peron 'kocsiállás (autóbusz-pályaudvaron)', politechnika 'müszaki egyetem, prefektúra'a kormány megyei hivatala', prefektus '(a kormányt képviselő) megyefőnök'; pretenciós 'igényes'; prodékán 'dékánhelyettes'; rahát 'szultánkenyér'; rodál '(gépjármüvet) bejárat'; telemea 'tehén- vagy juhtejből készített, sós (a görög feta sajthoz hasonló) sajtféleség'; termopán 'hőszigetelö (ablak vagy ajtó)'; tokány 'pörköltféle étel'; vinetta 'padlizsán'; vinilin 'PVC-padló'. ${ }^{26}$

${ }^{25}$ Az internetes Termini magyar-magyar nyelvi szótár jelenleg 1071 Erdélyben használt lexikai elemet tart számon (és 1691 szójelentést), amelyeknek több mint 95\% kontaktusjelenségnek tekinthető. Ebből egyszerü szó szintü, közvetlen átvétel 902 elem. (A többi indirekt átvétel vagy szószerkezet szintü kölcsönzés).

${ }^{26}$ A szócikkekben szereplő stilisztikai minősítések a korábbi és újabb kutatások eredményein alapulnak (Márton-Péntek-Vöő 1977, Benő 2004, Benő 2008). 
Ezek az általánosan elterjedt kölcsönelemek nagyobbrészt az erdélyi regionális köznyelv részeinek tekinthetők, lévén, hogy közismertek és a legkülönbözőbb társadalmi csoportok által használt, írott (sajtónyelvi) szövegekben is természetesként ható jövevényszavak. ${ }^{27} \mathrm{~A}$ közvetlen átvételeknek kevesebb mint 5\%-a sorolható ebbe a kategóriába.

A dialektális dimenzióban né p n y elvi minősítéssel jelennek meg azok a lexikális elemek, amelyek a kevésbé is kolázott (vidéki) beszélók által használt, regionális kötöttségű szavak, és több tájnyelvből is adatolhatók. A vizsgált adattárban 350 ilyen lexikai elemet találtam, amely a közvetlen átvételek mintegy $25 \%$-a. Az alábbi adatok szemléltetik ezt a dialektális kölcsönszóréteget: abonament 'autóbusz- vagy vonatbérlet(jegy)' 'bérlet'; adidász '(bármilyen márkájú) sportcipő'; ákációs 'izgága, kötekedő'; alimentára 'élelmiszerüzlet'; antibiotik 'antibiotikum'; árácset 'fehér, vízben oldódó ragasztó, amellyel rendszerint fát (esetleg papírt vagy más anyagot) ragasztanak'; 'fehérenyv', aragázbutélia 'propánbutángáz-palack'; árdéj 'zöld édespaprika'; árija'szérü', autobáza' gépkocsitelep'; autogára'autóbuszállomás'; bács 'számadó juhász'; bálmos 'fehérsavóban kukoricalisztből készített puliszkaszerü étel'; baszkulánt 'billenőautó'; báza 'terményátvevő és raktározó központ, árulerakat'; berbécs 'kos, bakkecske'; berszán 'havasi, román juhász'; bidon 'víz szállítására használt nagyobb ürtartalmú mủanyag palack vagy hordó'; biszijók 'bazsalikom'; bordura '(járda)szegély'; borkán 'beföttesüveg'; bosztán 'takarmánytök'; bukluk 'baj, bonyadalom'; bulándra 'rongy, rongyos, rendetlen öltözet'; burduf'tömlőben tárolt túró; tömlőtúró'; burján 'gyomnövény'; butélia 'palack, gázpalack'; cáp 'kecskebak'; cinka 'serdülő lány'; cuga 'disznó, malac'; cujka 'gyengébb, rendszerint egyszer főzött pálinka'; csimpolya 'bőrduda'; csintura 'derékszij', csobán 'juhász'; csubuk 'borravaló, baksis'; csuma 'pestis; kolera; üszög'; dajnál '(rosszul, részegen) énekel'; damika 'kenyérleves túróval'; dancs 'mocskos, piszkos ember'; dangubál 'lustálkodik, lopja a napot'; debella 'nagy termetü, testes nő'; diszpenzár 'körzeti orvosi rendelö'; dojna '(román) népdal'; döblec 'sütőtök'; dumnyezóját 'az istenit!' (káromkodás); esztena 'a juhnyáj nyári szálláshelye a pásztorok tanyájával együtt'; fáta 'román leány'; fataró 'meddö'; flotánt 'ideiglenes tartózkodási engedély'; frájer 'hiszékeny, naiv ember, mafla, balek'; ${ }^{28}$ frekál 'dörzsöl, súrol'; fustély 'dorong, furkósbot'; fuzsitus 'hirtelenkedő, szeleburdi'; gárdás 'ügyeletes' stb.

Az adatbázis dialektális dimenziójának másik kategóriája az idegenes minősítés. Az Értelmező szótár+ „idegen” minősítésének mintájára ez a terminus azokat a szavakat és kifejezéseket jelöli, amelyeket elsősorban

\footnotetext{
${ }^{27}$ Mint ismert a magyar köznyelv szókincsének mindössze 14 román eredetű eleme van. Ezek a következők: áfonya, bani, batul, cimbora, ficsúr, furulya, hodály, lej, málé, mokány, palacsinta, poronty, román, tokány (Márton-Péntek-Vöő 1977: 7).

${ }^{28} \mathrm{~A}$ románban német eredetü jövevényszó.
} 
a másodnyelvdomináns beszélők használnak. Ezek többnyire az erdélyi magyar regionális köznyelvben meg nem honosodott, idegen szó kategóriájú elemek, amelyek leginkább a romándomináns kétnyelvü beszélőknél fordulnak elő. Ilyenek többek között a következők: abonál 'előfizet, megrendel valamit (pl. újságot, étkezést)'; antitalent 'valamely területen teljesen tehetségtelen, hozzá nem értő ember'; aparát 'készülék'; automechanika 'autószerelés'; aviz 'értesítés (pl. postai küldeményről)'; bax 'csomag, pakk, láda (mennyiségű)'; bilánc 'egyenleg'; borderó 'kimutatás, kísérőjegyzék'; boxa 'hangfal'; braszeria 'falatozó, sörözö', bulándzsiu 'komolytalan, megbízhatatlan (ember), faragatlan fickó'; bursza 'ösztöndij'; cserere 'kérvény'; decsízió 'végzés, jogi döntés'; depozit 'lerakat'; diszketa 'számítógépes hajlékonylemez, floppi'; dováda 'bizonyítvány, igazolás'; ekipa '(munka)csoport'; ekonómista 'közgazdász'; fáza 'helyzet, alkalom'; fond 'pénzalap'; gisé 'pénztárablak, ügyfélfogadó ablak'; hándikápát 'fogyatékkal élö'; infermeria 'betegszoba; gyengélkedö'; kapota 'motorháztetö'; livret 'katonakönyv'; monetár 'címletkimutatás (pénztárzáráskor az egyes címletek számának megadásával'); negocsiál 'béralkut folytat'; omolgál 'hitelesít valamit, érvényesnek nyilvánít, eredetiségvizsgálattal hitelesít'; pontázs 'munkaidőmérés, jelenléti kimutatás'; randament 'hozadék, hozam, hatásfok'; spága 'csúszópénz'; 'szárcsina 'feladat, megbízatás'; tribunál 'törvényszék'; virament 'átutalás, átírás (pénzösszegé)' stb.

A vizsgált adatbázis olyan társadalmi dialektális kategóriát is tartalmaz, amelynek nincs hagyománya a magyar szótárirodalomban: az is k olá zott minősítést. Lanstyák István szerint az ilyen jellegű minősítés azért újszerü, szokatlan, mert a szótárírók maguk épp ebbe a kategóriába tartoztak, és számukra a saját nyelvhasználatuktól eltérő szavak stílusértéke a feltünő. Egy kölcsönszó, idegen szó vagy szójelentés akkor kerül ebbe a kategóriába, ha az adott nyelvi egység rendszerint az iskolázott nyelvhasználók beszédében szokott megjelenni. Íme, néhány adat ebből a szókészleti rétegből: abszolvál 'teljesít, elvégez, befejez, végrehajt valamit'; abszolvens 'valamilyen oktatási intézmény, pl. gimnázium, egyetem, zeneiskola (frissen) végzett diákja; pályakezdő'; anticipatív 'megelőlegezett' , 'megelőző', 'elébe vágó'; approbáció 'jóváhagyás'; donáció 'hagyomány'; kolonista 'a történelmi Magyarország utódállamainak magyarlakta területeire érkező; a többségi etnikumhoz tartozó telepes'; lokalitás 'meghatározott terület, helyszín'; lukratív 'jövedelmező'; metodista 'módszertannal foglalkozó (személy); módszertanos'; moderátor 'müsorvezető'; szignalizációs '(biztonsági) jelzőrendszerrel kapcsolatos'.

Az iskolázott beszélők nyelvhasználatában a közvetlen átvételek jelentős része hangalakkölcsönzés,, amellyel részletesebben a IV.5. alfejezetben foglalkozunk. 
A tájnyelvi minősítés olyan szókészleti elemeket jelöl, amelyeknek földrajzi elterjedtsége ismereteink szerint egy-két szűkebb régió nyelvváltozatában fordul elő, nem közismert a kevésbé iskolázott beszélők körében sem. Az adatbázis viszonylag kevés ilyen jellegű elemet tart számon, és gyakran csak bizonyos jelentésükben bizonyulnak tájnyelvi jellegünek. A következő közvetlen átvételek példázzák ezt a kölcsönszóréteget: braszka 'béka'; budza 'ajak'; bula 'nő, lány'; cunder 'salak, reve',29 csetenye 'fenyőfa'; csuma 'kísértet'; deszkintál 'ráolvasással gyógyít; megigéz, megront'; fustély 'létrafok'; gidil 'csikland'; hajde 'hajrá!'; prikulics 'boszorkány'; puj 'csirke, fióka'; srót 'állatok etetésére való kukorica- vagy búzadara'; tentelló 'kissé ütődött'.

A regiszterbeli hovatartozás tekintetében a Termini-szótár és adatbázis megkülönböztet szaknyelvi, szépirodalmi, sajtónyelvi, közéleti és szlenghez tartozó szavakat. (Kimondottan szépirodalmi nyelvü lexikai elemet nem tart számon a szótár, viszont a többi regiszterbeli kategóriában igen nagy számban fordulnak elő kölcsönelemek, amint az alábbi csoportosításokból látható. ${ }^{30}$ )

A szaknyelvi minősítés a különféle szakmák és szakterületek laikusok által nem vagy kevéssé ismert szakszavainak sajátos stílusértékét jelöli. Jóllehet konkrét szavak esetében nem mindig könnyű eldönteni, hogy kimondottan szaknyelvi elemmel van-e dolgunk, vagy pedig közismert és így köznyelvinek tekinthető szóval, ez a megkülönböztetés feltétlenül szükséges, mivel vannak határozottan szaknyelvinek tekinthető kölcsönelemek is: agregát 'áramfejlesztő vagy egyéb energiát előállító erőgép'; capina 'rönkfordító, rönktaszító'; delkó 'gyújtáselosztó'; dividend 'részvények utáni éves osztalék'; indemnizáció 'pótlék'; kanalizáció 'szennyvízcsatorna(rendszer)'; kantonament 'edzőtábor'; kaszka 'bukósisak, védősisak'; kocsorba 'szénvonó'; kofrázs (kofrács) 'zsaluzat'; kompona 'a fejös juhászatban egy fejősjuh után egy fejési idényre a jószág tulajdonosának a juhásztól járó túrómennyiség'; misling 'sűrűn vetett kukorica mint zöldtakarmány'; 'csalamádé'; nomenklator '(oktatási, képzési) szakjegyzék'; pendlizik '(előadóművész) több helyen is föllép'; plakázs 'furnérlemez'; ránga 'emelésre használt vasrúd'; rekuperáció 'orvosi rehabilitáció'; szanitár 'segédápoló' stb. Megjegyzendő, hogy a szaknyelvi regiszterben is számos olyan elem található, amely hangalakkölcsönzésnek tekinthető.

\footnotetext{
${ }^{29}$ Német eredetű szó

${ }^{30}$ Megjegyzendő, hogy a regiszterbeli minősítések nem kizárólagosak, lévén, hogy egyazon lexéma esetében több minősítés is érvényes lehet. Például előfordulhat olyan szó, amely egyaránt tekinthető sajtónyelvinek és közéletinek. A Termini szótár és adatbázis lehetővé teszi az ilyen kettős minősítésű kölcsönszavak megjelenítését.
} 
Az adattár sajtónyelvi minősítése a tömegtájékoztató eszközök nyelvére jellemző szókészleti elemek sajátos stílusértékére utal. Ebben a stílusrétegben is találunk közvetlen kölcsönszavakat, amint az alábbi adatok ezt jelzik: editál 'megjelentet, kiad'; kondukátor 'Nicolae Ceauşescu, egykori román elnök és pártfőtitkár egyik megnevezése'; lusztráció '(politikai indítékú) átvilágítás'; moderál '(rádióban, televízióban stb.) műsorvezetőként közreműködik; műsort, vitát stb. vezet'; moderátor 'müsorvezetö'; vátrás 'a Vatra nevü nacionalista-soviniszta „kulturális" szervezet tagja, vagy az ezzel az intézménnyel szimpatizáló személy'.

Az elemzett adatbázis regiszterbeli dimenziójára használt közéleti minősítés olyan, a társadalmi élettel, a kultúrával, a közigazgatási ügyekkel kapcsolatos szavakra utal, amelyek nemcsak a szakmai nyelvhasználatban jelentkeznek, hanem a nagyobb nyilvánosságnak szánt, különféle típusú megnyilatkozásokban is, és ennek következtében közismerteknek tekinthetők. Idetartoznak többek között a következő kölcsönelemek: ámenda 'pénzbírság'; asszocsiáció 'lakóközösségi szervezet'; bón 'élelmiszerjegy'; buletin 'személyi igazolvány'; csirkuláció 'közlekedés'; dekontál 'utólag elszámol; kifizet'; delegáció 'hivatalos kiszállás'; detasál 'ideiglenesen áthelyez'; dováda 'bizonyítvány, igazolás'; duplikát 'hivatalos iratnak az eredetivel egyező, egyenlő értékủ példánya; másolat'; fiszk 'adóhivatal, pénzügyi igazgatóság'; inkadrál 'felvesz, besorol (munkahelyre, fizetési osztályba)'; kitánca 'nyugta, elismervény'; komiszion 'jutalék, illeték'; kont 'folyószámla'; kontesztál' (követelést, vizsgaeredményt stb.) megtámad, megfellebbez'; kumul 'álláshalmozás, másodállás'; kvesztor 'rendőrkapitány'; liceális 'középiskolai'; miting 'gyülés, nagygyưlés'; prefix 'távhíváskor használt körzetszám'; prokuratúra 'ügyészség'; rajon 'körzet'; reanimáló 'a különleges(en gondos) kezelést igénylőknek létesített osztály; intenzív osztály'; repartizál 'vkit vhova beoszt, kinevez'; reszort 'működési terület, feladatkör, hatáskör'; somer 'munkanélküli'; szektor 'kerület (pl. nagyvárosé), körzet (pl. egy rendőrbiztos által felügyelt övezet)'; szekus 'romániai politikai rendőrség alkalmazottja (a kommunizmusban)'; szekusság 'a kommunizmusbeli román politikai rendőrséghez való tartozás'; szesszió 'parlamenti ülésszak'; szfát 'egy település vezetői testülete; néptanács'; taksza 'hivatalosan kiszabott díj, illeték'; talon 'forgalmi engedély'; virament 'átutalás, átírás (pénzösszegé)' stb. 148 lexéma, a direkt kölcsönelemeknek mintegy 10\%-a sorolható ebbe a regiszterbe, és ez jelzi, hogy a többségi nyelv kizárolagosan hivatalos nyelvi státusa igen nagymértékben kedvez az ilyen jellegü átvételeknek.

Az adatbázis erdélyi anyaga szleng minősítéssel jelöli a regiszter dimenzióban azokat a kölcsönszavakat, amelyek inkább a fi a ta lok, inkább a városi szubstandard nyelvváltozat elemeinek tekinthetők, és gyakran 
sajátos emocionális töltet és stílusérték jellemzi őket. Ebbe a regiszterbe sorolt melléknevek gyakran negatív, nemkívánatos tulajdonságokat jelölnek: bukluk 'bajkeveró'; bulándzsiu 'komolytalan, megbízhatatlan (ember), faragatlan fickó'; deszkurkarec 'leleményes, életrevaló, talpraesett' (gyakran pejoratív értelemben); flegma 'nagyképű (személy)'; gamat 'rossz, utálatos'; hándikápát 'fogyatékkal élo"'31; lunguj 'magas, hórihorgas (ember)'; málészájú 'mamlasz'; proszt 'ostoba'; tentelló 'kissé ütődött'. Hasonlóképpen ebbe a regiszterbe tartozó i g é k többsége szintén negatív cselekedetre utal: blattol 'érvényes menetjegy nélkül utazik; potyázik, bliccel'; csubukol 'mellékkeresetért dolgozik'; dajnál '(rosszul, részegen) énekel'; elcsupál 'eltulajdonít; valakitől igazságtalanul elvesz valamit'; frekál 'erősen megdolgoztat'; letácsol 'elhallgattat, leint, letorkol'; megmurál 'meghal, megdöglik'; mutujkodik 'butáskodik, ügyetlenkedik'. A szleng minősítést hordozó fónevek körében is igen sok a pejoratív jelentésű szó: bulándra 'erkölcstelen nö'; dancs 'mocskos, piszkos ember'; domn 'úr'; fenta 'csel trükk'; frájer 'hiszékeny; naiv ember; mafla; balek'; gáska 'csapat, banda'; kontrol 'ellenőr'; kotyec 'kunyhó, putri'; pila 'protekció, támogatás, összeköttetés valamilyen ügy elintézésében'; polic 'rendőr'; popor 'nép'; spekulánt 'agyafúrt, furfangos, dörzsölt ember'; szkándál 'veszekedés, botrány'.

A diáknyelv vagy diák szleng köréből származnak a következő adatok: intri 'diákotthon, kollégium'; kamin 'kollégium'; tocsi 'magoló diák'; tocsilár 'stréber'. Angol eredetű diáknyelvi elemek: bébi 'lány'; coffee 'kávé'; cool 'tetszetôs'; csettelés 'társalgás'; feeling 'hangulat'; femili 'család'; féjsz 'Facebook/közösségi oldal'; happy 'boldog'; hitt 'sláger'; lávsztori 'szerelmi történet'; love 'szerelem' (lávcsi kicsinyítő képzős alakja is van); lúzer 'vesztes; gyenge jellemü'; money 'pénz'; oké 'jó, rendben van'; shopping 'vásárlás'; smiley'mosoly' (Homonai 2014).

A katonai szleng szavai gyakran érintkeznek a szaknyelvi minősítéssel, hiszen itt egyrészt egy zártkörű csoport nyelvváltozatáról van szó, és ugyanakkor egy szakmai nyelvváltozatról is, lévén, hogy a hadsereghez való tartozás a katonai szaknyelv elsajátításával jár együtt. Ezek a lexikai elemek idegenesnek is tekinthetők, hiszen az adott nyelvváltozatban romándomináns beszélők megnyilatkozásaiban fordulnak elő. A következő kölcsönelemek tartoznak ebbe a csoportba: comisariat [komiszáriát] 'hadkiegészítő parancsnokság'; csintura 'derékszíi'; dorobánc 'gyalogos katona'; fruntás 'őrvezetö'; infermeria 'betegszoba; gyengélkedö'; kolonél 'ezredes'; komándánt 'parancsnok'; koncsentra 'tartalékosok behívása'; major 'örnagy'; patrula 'őrjárat'; plutonier 'őrmester'; szerdzsent 'szakaszvezető'.

\footnotetext{
${ }^{31}$ A románban angol eredetü jövevényszó: ang. handicapped 'fogyatékkal élő' > r. handicapat 'ua.'
} 
A vizsgált adattár direkt kölcsönelemeinek a körében összesen 71 kölcsönelem tekinthető a szleng regiszterbe tartozónak, és ez a direkt kölcsönelemek $5 \%$-át jelenti.

\section{Köznévi kölcsönzések a stílusváltozat és az érzelmi viszonyulás szempontjából}

A szótári egységek stílusváltozati kötöttsége bizonyos beszédhelyzetekben való előfordulására utal, és közvetve a beszélgető társak egymáshoz való viszonyát is jelzi. Azt mondhatjuk tehát, hogy a lexikai elemek stílusváltozati minősítése elsősorban a beszédhelyzet formális vagy informális jellegére vonatkozik. A tanulmányozott korpusz a formális-informális dimenzióban minősíti az adatbázisban megjelenített egységeket közömbösnek, választék osnak vagy bizalmasnak. A Termini-szótár a választékos kategórián belül megkülönböztet emelkedett minősítést is. Ez olyan szavaknak a sajátja, amelyek a beszélők számára érzelmileg telítettek és esztétikai értéket is hordoznak, ünnepélyes, fennkölt hangulatúak. Hasonlóképpen a bizalmas minősítés keretében lezser kategóriát is alkalmazza a szótár, amely a legnagyobb mértékben informális, a legintimebb, a legoldottabb beszédhelyzetben használat szavak, illetve alakváltozatok. A lexikográfiai adatbázis minősítő rendszerében ez a kategória leginkább a lazításos ejtésváltozatra vonatkozik. Sem az emelkedett, sem a lezser kategória nem jellemző az adatbázis elemeire, ami azt jelzi, hogy a kölcsönelemek állandósult stílusértéke jelentős mértékben behatárolt.

A sajátos stílusérték hiányára utal a vizsgált adatbázisban a kö zö m bös minősítés. Ezek olyan lexikai elemekre vonatkoznak, amelyek bármilyen beszédhelyzetben előfordulnak, és nem zavaróak sem a nagyon formális, sem a nagyon informális nyelvhasználati helyzetben. Ez a stílusértékbeli kategória rendszerint meghonosodott kölcsönelemekre, jövevényszókra utal. Olyan elemekre, amely szerves részei az erdélyi magyar nyelvváltozatnak regionális vagy szaknyelvi szinten, de nemritkán a regionális köznyelvnek is. Többek között a következő adatok nyerték el ezt a minősítést: aragáz 'propánbután-gáz'; autógára 'autóbuszállomás'; bács '(számadó) juhász'; bálmos 'fehérsavóban kukoricalisztből készített puliszkaszerü étel'; bani '1/100 lej értékű aprópénz'; bankomát 'pénzkiadó automata'; berbécs 'kos'; blicc 'vaku'; bordura '(járda)szegély; breton 'frufru'; buletin 'személyi igazolvány'; burján 'gyomnövény'; cujka 'gyengébb, rendszerint egyszer főzött pálinka'; cserge 'bolyhos gyapjútakaró'; csorba 'savanyú leves'; dojna '(román) népdal'; elhurbol 'elnyü, elvisel, elhasznál'; fotókopia 'fénymásolat', halva 'általában napraforgómagból, cukor felhasználásával készült édesség'; jaurt 'tejsavbaktériumokkal mesterségesen savanyított aludttej'; 
kaláka 'népi társas munka'; karióka 'filctoll'; kazettofon 'kazettás magnetofon'; komisszió 'bizottság'; kulturista 'testépítő, body-builder'; kulturista 'testépítés, body-building'; kvesztor 'rendőrkapitány'; marmaládé 'lekvár, íz'; milícia 'rendőrség'; milicista 'rendőr'; mokány 'havasi román'; moketta 'padlószőnyeg; szőnyegpadló'; motorina 'gázolaj, nyersolaj'; murok 'sárgarépa'32; oltyán 'Olténiában (a Déli-Kárpátok és az Al-Duna között) élö, román nyelvü népcsoport'; orda 'édes, sajtszerü termék'33; pionír 'az úttöröszervezet tagja a szocializmus időszakában', plasztelin 'gyurma', poliklinika 'rendelőintézet', politechnika 'müegyetem, müszaki egyetem'; prefektúra 'a kormány megyei hivatala'; prefektus '(a kormányt képviselö) megyefőnök'; pufajka 'vattakabát, vattaruha'; rahát 'szultánkenyér' stb.

A közömbös minősítésü kölcsönelemek körében számos olyan lexikai egység található, amely szószerkezetszintű vagy indirekt átvétel: tükörszó, tükörkifejezés vagy jelentéskölcsönzés. (Ezekről részletesebben 1. az V.1., V.2. és V.3. fejezetet)

A választékosnak minősített lexikai egységek többnyire formális beszédhelyzetben használt, leginkább írásban előforduló szókészleti egységek. Az ilyen jellegü idegen eredetü szavaknak bizonyos presztízse van a müvelt beszélők szemléletében. Az erdélyi adatok sorában a következő szavak minősítő rendszerében szerepel a választékos minősítés: abszolvál 'elvégez valamilyen iskolát'; abszolválás 'valaminek a teljesítése, elvégzése'; ambulancia 'járóbeteg-rendelés (helyisége)'; approbáció 'jóváhagyás'; argumentáció 'érv(elés)'; klientalizmus 'kliensrendszer; klientúrarendszer'; kompetenció 'illetékesség'; konverzáció 'társalgás, beszélgetés'; kvalitásos 'jó minőségű, minőségi'; lokalitás 'meghatározott terület, helyszín'; ökológizál 'védi a környezetet, csökkenti a környezetszennyezést'; preszkriptív 'előíró, preskriptív'. A választékos stílusminősítésű elemek főleg az iskolázott beszélők megnyilatkozásaiban jelentkeznek, és gyakran írott szövegekben, amint ezt az adattár is jelzi azzal, hogy egyfajta korreláció figyelhető meg az iskolázott regiszterbeli minősítés és a választékos minősítés között: a 12 közvetlen kölcsönzésü választékos lexikai elemből 11 (91,6\%) az iskolázott beszélőkre jellemző. Ugyanakkor az ebbe a stílusértékű kategóriába sorolt lexikai elemek alacsony száma azt jelzi, hogy ez a stílusminősítés nagyon kismértékben jellemző az erdélyi magyar nyelvváltozatokban használt kölcsönelemekre.

Ezzel szemben a bi zalm a s stílusminősítés a közvetlen átvételek nagy többségét jellemzi (kb. 60-70\%-át), ami arra utal, hogy ezek a nagyobbrészt az államnyelvből származó közvetlen átvételek, amelyek rendszerint nem formális helyzetben és leginkább a szóbeliségben gyakoriak, elterjed-

\footnotetext{
${ }^{32}$ Szláv eredetű szó, amely tájnyelvi szinten nemcsak Erdélyben használatos.

${ }^{33}$ Román eredetű köznyelvi magyar szó.
} 
tek. Olykor az erdélyi, iskolázott beszélők a standard és az informális, bizalmas stílusértékű szót egyaránt ismerik és használják, de a kettő között funkcionális megoszlás jön létre a stílusváltozati dimenzión: a köznyelvi szó lesz a közömbös vagy emelkedett értékű, és a kölcsönszóbeli párja pedig a bizalmas, amint ezt az alábbi adatok szemléltetik: személyi igazolvány - buletin; billenöautó - baszkulánt; fürdômedence - bazin; egyenleg - bilánc; befóttesüveg - borkán; földtoló gép - buldozer; sugárút - bulevárd; höközpont csentrála; képviseló - deputát; eltulajdonít - elcsupál; szakértô - expert; áruszámla - faktura; cég - firma; ürlap - formulár; ügyelet - gárda; paradicsompaprika - gogos; pótlék - indemnizáció; leltár - inventár; menedékház - kabana; edzótábor - kantonament; motorháztető - kapota; bukósisak - kaszka; kontár - kirpács; ügyfél - kilent; rendörbiztos - komiszár; elkoboz - konfiszkál; fellebbez - kontesztál; ellenőr - kontrolór; elhallgattat - letácsol; pdlizsán - vinetta stb. Természetesen, ezeknek a szinonimapároknak a konnotatív jelentése és expresszivitási értéke is gyakran eltérő.

Az érzelmi viszonyulás tekintetében a lexikográfiában megszokás különböztetni eufemisztikus (szépítő), kedveskedő, tréfás (humoros), pejoratív (rosszalló), ironikus (gúnyos), durva és trágár minősítést. A Termini-adatbázis ebbe a kategóriába sorolja a kifejező értéket, az expresszivitást is.

A tréfás minősítés olyan szavakra utal, amelyeknek állandósult stílusértéke a humoros sajátosság, és a jelöltet egyfajta felülnézetből, derűsen szemlélteti. Ilyen kölcsönszavaknak minősülnek a Termini-szótárban a következők: bába 'öregasszony'; braszka 'béka'; kaput 'meghalt, megdöglött' (német eredetű jövevényszó); megmurál 'meghal, feldobja a talpát'; megszkapál 'megmenekül'; meszeriás 'iparos'; putyeró 'erő'.

A pejoratív értékű kölcsönszók a denotátummal szemben negatív viszonyulást (lekicsinylést, helytelenítést, elítélést, megvetést) fejeznek ki, és így az ilyen természetü lexémák rendszerint nemkívánatos emberi tulajdonságokat, minősítéseket vagy cselekedeteket jelölnek: bulándra 'erkölcstelen nő'; dajnál '(rosszul, részegen) énekel'; dancs 'mocskos, piszkos ember'; debella 'nagy termetü, testes nő'; fataró 'meddő; hermafrodita'; flegma 'nagyképü'; frájer 'hiszékeny, naiv ember, mafla; balek'; frekál 'erősen megdolgoztat'; fuzsitus 'hirtelenkedő, szeleburdi'; gamat 'rossz, utálatos'; kartier 'lakótelep'; kirpács 'kontár'; lunguj 'magas, hórihorgas (ember)'; mutuj 'ügyetlen, buta'; mutujság 'ügyetlenség, butaság'; nyám 'rokon, rokonság'; pokajit 'vallásos szekta tagja, hívő'; popor 'nép'; prapagyit 'züllött, semmirekellő, mihaszna'; putregáj 'lusta, ronda'; séf 'főnök'; spága 'csúszópénz'; szerecsia 'nyomorult, szerencsétlen'; szpurkát 'tisztátalan'; tocsi, tocsilár 'magoló diák'; tokmál 'rábeszél valakit valamire, rátukmál'; turma 
'önálló akarattal nem rendelkező embercsoport'; zsingás 'kényes, gyenge, törékeny' stb.

Mivel az ir onikus és a durva minősítésre mindössze néhány adatot találtunk a korpuszban, messzemenően a pejoratív értékű kölcsönelemek szerepelnek a legnagyobb számban az érzelmi viszonyulást kifejező, állandósult emotív értékű kölcsönelemek körében.

A szavak expresszivitásának, kifejező értékének forrása lehet a hangalak és a jelentés, amint azt Arisztotelész óta tudjuk. A hangtestből fakadó expresszivitás esetén a két beszédpartner (vagy tágabb értelemben az adott nyelvközösség) szemantikai motiváltságot fedez fel a jelsor (a hangalak) és a jelentés között. Ebbe az inherens expresszivitásnak nevezett kategóriába (Péter 1984) sorolható a szokatlan hangalakú, a hangutánzó, hangulatfestô és ikerített szavak mellett a népetimológia olyan eseteit, amelyekben a hangalak módosítása jelentésváltozással jár együtt. A jelentésből származó expresszivitás Péter Mihály idézett tanulmánya alapján a d herens expresszivitásnak nevezhetó, és a metaforikus, metonimikus jelentéstöbbletet hordozó lexikai elemekre jellemző ez a sajátság. ${ }^{34}$

A Termini-adatbázisban szereplő kölcsönelemek közül a következőkre jellemző a hangalaki expresszivitás: bukluk'baj, bonyadalom'; blattol 'érvényes menetjegy nélkül utazik; potyázik, bliccel'; blicc 'vaku'; bozgor 'hazátlan'; bulándra 'erkölcstelen nő'; bulándzsiu 'komolytalan, megbízhatatlan (ember), faragatlan fickó'; cuga 'disznó, malac'; curukk, curükk'vissza < lóterelő szóként>' (német eredetü jövevényszó); csubuk 'borravaló, baksis'; dajnál '(rosszul, részegen) énekel'; dangubál 'lustálkodik, lopja a napot'; debella 'nagy termetü, testes nö'; frekál 'dörzsöl, súrol'; fuzsitus 'hirtelenkedő, szeleburdi'; gogos 'paradicsompaprika'; kokalár 'városi vagány, gazdagság és vagányság látszatát hajhászó ember'; kukra 'egyenesen, magasan fölfelé, magasra'; letácsol 'elhalgattat, leint, letorkol'; lunguj ' magas, hórihorgas (ember)'; mutuj 'ügyetlen, buta'; mutujkodik 'butáskodik, ügyetlenkedik'; parapács 'beszédes'; popor 'nép'; prapagyit 'züllött, semmirekello,, mihaszna'; prikulics 'kísértet, fantom, rossz szellem'; pufulec 'kukoricapehely'; soson 'hócipö'; szokotál 'fontolgat'; szpurkát 'tisztátalan'; tentelló 'kissé ütödött'; zdránca' ringy-rongy' stb. Az eddigi kutatások azt jelzik, hogy a kölcsönelemek hangalaki expresszivitása olyan hangzássémákhoz köthető, amelyekben fontos szerepe van a szótag- és hangismétlésnek, valamint a szóeleji vagy ismétlődő mássalhangzó-torlódásnak (Benő 2004: 25-47).

A jelentésbeli expresszvitás jelenségét leginkább a nép- és tájnyelvi adatok szemléltetik. Ezért itt $A$ magyar nyelvjárások román kölcsönszavai (Márton-Péntek-Vöö 1977) címü monográfiából származó lexikai

\footnotetext{
${ }^{34}$ A román eredetü kölcsönelemek expresszivitásával kapcsolatban 1. Benő 2000.
} 
elemekkel szemléltetem a metaforikus jelentések érvényesülését. A metaforikus jelentés közvetlen módon történő átvétele, mint általában a szemantikai motiváltság, kapcsolatban van expresszivitás kérdésével, hiszen a metaforikus láttatásban információs értéktöbblet is létrejön azáltal, hogy a névátvitel alapjául szolgáló attribútum elótérbe kerül. ${ }^{35}$ Mint ismert, a metaforikus megnevezésben két entitás azáltal érintkezik, hogy a közösnek vélt attribútum összekapcsolja őket. Ha ez a metaforikus képzettársítás az újdonság erejével hat, a hasonlított a hasonlón keresztül értelmezödik, azaz örökli egy részét azoknak a nyelvi minősítettségnek, amelyeket a hasonlónak tulajdonítunk. Ebben az észlelési folyamatban a megnevezett entitás sajátos nézőpont eredményeként adott. A nyelvek érintkezésénél különös súllyal jelentkezik ez a kérdés, hiszen a különböző nyelvek szemantikai rendszerében eltérő metaforikus jelentésmezőket is találhatunk, és ezeknek az eltérő struktúráknak a beszélő általi észlelése kommunikációs élményt jelenthet. A megnevezés ilyen értelmű kifejező ereje affektívemotív összetevővel is gazdagíthatja a beszéd folyamatát. Ez a szemantikai alapú motivációs tényező a kölcsönzések indítékaira is fényt vet. A kétnyelvű beszélő a második nyelvbeli lexémát azért is használhatja az anyanyelvi kommunikációja során, mert a szó szemantikai motiváltságánál fogva alkalmasnak tűnik arra, hogy hatékonyan és érzékletesen fejezze ki mondanivalóját és ezzel együtt a denotátumhoz való viszonyát is. Az elemzett kölcsönszóanyagban bőven találhatni példát a közvetlen metaforikus jelentésátvételre. Az alapjelentéssel együtt történő metaforikus jelentés átvételét megkönnyítheti az, hogy az anyanyelv jelentésrendszerében is előfordulnak hasonló irányú képzettársítások (például az emberi jellemvonásokra, attitűdökre alkalmazott állati tulajdonságok). Megjegyzendő, hogy a metaforikus jelentés kifejezőereje az alapjelentés mentén érvényesül. Az aktív kétnyelvü beszélők egyaránt ismerik az etimon elsődleges és másodlagos jelentését, és a két jelentés egymásba játszása folytán érzékelik a kifejezésbeli többletet is. A következő metaforikus névátvitelre utaló adatok egyazon helységben vagy tájszólásban az etimon tulajdonképpeni és névátviteles jelentésében is használatosak:

r. broască 1. 'béka'; 2. 'kisgyerek' > m. braszka 1. 'béka'; 2. 'varangyos béka'; 3. 'leányka, serdülő leány' (máramarosi tájszólás.) mente)

r. ținţar 1.'szúnyog'; 2. 'sovány (ember)' > m. cincár 'ua.' (Kis-Szamos

r.cioară 1. 'varjú, csóka'; 2. 'fekete képű ember' > m. csára 'ua.' (Dés)

r. căciulă 1. 'kucsma'; 4. 'tollbóbita a madár fején' > m. kacsula 'ua.' (gyimesi csángó nyj.)

${ }^{35}$ Az expresszivitás és az információs értéktöbblet összefüggését 1. Benkő 1988. 
r. trîntor 1.'hereméh'; 2. 'ingyenélö' > m. trintor 'ua.' (Kis-Szamos mente)

r. mocăniţă 1.'zömök havasi tehén, ritkábban ló'; 2. 'keskeny vágányú, hegyekben közlekedő vonat' > m. mokonyica 'ua.' (Kis-Szamos mente)

r. piţigoi 1.'cinke'; 2. 'sovány ember' > m. picigoj 'ua' (Középlak)

r. învîrti 1.'forog, forgat'; 2 . 'ügyet nem tisztességesen elintéz' > m. virtyál 'ua.' (Szamosújvár, Kisiklód)

Amint látható, az adatok többsége kétnyelvưséggel jellemezhető vidékekről származik, ami erősíti a fentebb elmondottak érvényességét.

Mintegy következetésként jelzem, hogy az újabb keletű kontaktológiai kutatások kiemelik, hogy a stílusváltozati kötöttség, az emotív érték és az expresszivitás mint funkcionális megkülönböztető jegy indítéka lehet a szó átvételének vagy meghonosodásának (Szilágyi 2007, Benő 2004: 93120., Benő 2008: 109-131).

\section{Tulajdonnév-kölcsönzés, betûszók átvétele}

A hagyományos kontaktológiai leírás kisebb mértékben foglalkozik a tulajdonnév-kölcsönzéssel. A kontaktusok szempontjából a földrajzi nevek és a személynevek (elsősorban a családnevek) alkotják azt a csoportot, ahol számba vehető mértékben jelentkezik a román hatás. A betúszók külön csoportot alkotnak a tulajdonnévi kategóriában, és amint látni fogjuk, leggyakrabban intézménynevekre vonatkoznak.

\subsection{Földrajzi nevek átvétele}

A köznevekhez vagy akár a családnevekhez képest Erdélyben a román eredetü földrajzi nevek száma viszonylag kevés, aminek ismert történelmi és településtörténeti okai vannak, és elsősorban Erdély peremvidékein, az intenzívebb nyelvi kontaktusok régióiban jelentkeznek. Kniezsa István szerint a legkorábbi román eredetű helységnevek a XIV. század közepéről származnak, és a Krassó-Szörény megye északi részén található öt helységet jelölik: Kaprevár (< r. Căprioara), Marzsina (<r. Margina), Nuksora $(<\mathrm{r}$. Nucşoara), Riusor (<r. Râuşor) és Csernisora (<r. Cernişoara). A későbbiekben, a XVI. században már Szolnok-Dobokában, Biharban a Fekete-Körös völgyének felső részén, Fogaras, Alsó-Fehérnek hegyvidéki részén, Krassó-Szörénynek facseti kerületében és néhány kisebb területén is jelentkeznek román eredetü földrajzi nevek: Plopis (< r. Plopiş), Rusor (< r. Ruşor), Magura (< r. Măgura), Karbunár (< r. Cărbunar), Gropa (< r. Groapa), Kerpenyes (< r. Cărpeniş), Zernyest (< r. Zărneşti), Facset (< r. Făget), Szacsal $(<\mathrm{r}$. Săcel) (Kniezsa 1941). 
Ma is a hagyományosan intenzív román hatású dél-erdélyi és bánsági megyékben található a legtöbb román eredetű földrajzi név. Íme, néhány román eredetű településnév ebből a régióból megyék szerint csoportosítva:

Hunyad megye: Banica (< r. Băniţa), Batrina (< r. Bătrâna), Bulzesd (< r. Bulzeşti), Kristyor (< r. Crişcior), Martinesd (< r. Mărtineşti), Burzsuk (< r. Burjuc).

Szeben megye: Resninár (< r. Răşinari 'gyantaszedők' vagy 'szurokfözők') Guraró (< r. Gura Râului $\leftarrow$ La Gura Râului < szó szerint: 'a folyó torkánál'>), Kercisóra (< r. Cârțișoara), Polyán (< r. Poian), Szelistye (< r. Săliște).

Brassó megye: Bucsum (< r. Bucium $\leftarrow$ bucium 'tönk'), Dragus $(<\mathrm{r}$. Drăguș, Kacsuláta (<r. Căciulata $\leftarrow$ căciulat'süveges'), Mardzsinen (<r. Mărgineni $\leftarrow$ mărgineni 'a határon/szélen élők'), Mundra $(<\mathrm{r}$. Mândra $\leftarrow$ mândra 'szép'), Persány $(<\mathrm{r}$. Perșani $\leftarrow$ Perșa férfinév), Predeál $(<\mathrm{r}$. Predeal $\leftarrow$ predlea 'határ'), Rádos (<r. Roadeș), Vledény Vlădeni $\leftarrow$ Vlad férfinév).

Krassó-Szörény megye: Majdán $(<\mathrm{r}$. Maidan $\leftarrow$ maidan 'üres telek, foghij', Globukrajova (<r. Globu Craiovei), Obrézsa (<r. Obreja $\leftarrow$ obrejă r.ny. 'hordalékos folyópart', Székul $(<\mathrm{r}$. Secul $\leftarrow$ secul 'száraz'), Toplec $(<\mathrm{r}$. Topleț), Závoly $\left(<\right.$ r. Zŭvoi) ${ }^{36}$

A román eredetű földrajzi nevek körében kiemelendők a nagyobb régiókat elválasztó hegyek, hegycsúcsok nevei, mivel ebben a fogalomkörben több román eredetú földrajzi név adatolható. Ezek egy része egyszerú név, másrésze pedig összetett név hegység vagy havas utótaggal: Baiului-hegység (Báj-havas vagy Girbó) (<r. Munții Baiului, Gârbova); Bucsecs (<r. Bucegi); Cozia-hegység (Kozia) (< r. Masivul Cozia); Gutin (<r. Masivul Gutâi); Latorica (< r. Munții Latoriţei); Omu (< r. Omu); Pintyiló (< r. Masivul Penteleu); PojánaRuszka (<r. Munții Poiana Ruscă); Retyezát (< r. Retezat) Vlegyásza (Vigyázó) (<r. Vlădeasa), Lotru-hegység (Lator-havas) $(<\mathrm{r}$. Munții Lotru).

\footnotetext{
${ }^{36}$ Megjegyzendő, hogy a magyar és a román nyelv kölcsönös, kétirányú kontaktusfolyamataiban a földrajzinév-kölcsönzés szempontjából nyilvánvaló aszimmetria van: az ismert településtörténeti folyamatokkal összefüggésben a román nyelv többszörösét kölcsönözte az erdélyi településneveknek a magyarból, mint amennyi erdélyi földrajzi nevet a magyar átvett a románból. Íme, néhány adat a románba átkerült magyar eredetű településnevekből: Nagyfalu > Nuşfalău, Kisfalud > Chişfalud, Chişfalău; Nagylak > Nădlac; Újlak > Uileac, Uilac, Uliuc; (Maros)Újvár > Uioara; Széplak >Seplac, Suplac, Săplac; Kislaka > Chişlaca; Középlak > Cuzăplac; Szamosfalva > Someşfalău; Györgyfalva > Ghiurfalău; Papfalva > Popfalău; Kardosfalva > Cardoşfalău; Bányabükk > Banabic; Jenő > Ineu; Válaszút >Valasut, Olosut; Nagysebes >Sebişul Mare; Malomszeg > Molonsâg; Komjátszeg > Comățig; Várfalva > Varfalău; Alsó- és Felsőszentmihály > Sânmihaiul de Jos, Sânmihaiul de Sus; Segesvár > Sighişoara; Temesvár > Timişoara; Várad (Nagyvárad) > Oradea; Doboka > Dăbâca; Szeben > Sibiu; Fogaras >Făgăraş; Hátszeg > Hațeg; Hunyadvár > Hunedoara.
} 
Az erdélyi régiók, megyék vagy szűkebb tájegységek román eredetű földrajzi neveinek rendszeres feldolgozása még nem történt meg. Ezért ezen a területen még további kutatásokra van szükség. Olyan monográfiákra, mint Rácz Anita munkája: A régi Bihar vármegye településneveinek történeti-etimológiai szótára (Rácz 2007). Ennek a szótárnak az adatai azt jelzik, hogy a földrajzi nevek szintjén is megkülönböztethetők elsődleges és másodlagos átvételek. (Ez utóbbi kategória az olyan kölcsönelemekre vonatkozik, amelyek az átvevő nyelv korábbi elemeivel kombinálódva, egyfajta szóteremtő eljárással új lexikai egységeket hoznak létre az elsődleges átvételekből.) Rácz Anita monográfiájában szereplő elsődleges földrajzi kölcsönneveket példázzák a következők: Dombrovány 'település Bihar vm D-i részén Belényestől DK-re, a Petrósz-Körös völgyében' $(<\mathrm{r}$. dumbravă 'cserjés, sarjerdő, liget'); Fonác 'település Bihar vm. D-i részén Rézbánya mellett ÉNy-ra, a Fekete-Körös jobb partján' (< r. finaţe 'kaszálók' ); Grós 'település Bihar vm. D-i határánál Bél mellett K-re, a Fehér-Körös közelében' (< r. rom. gros 'fatuskó, fatönk'); Gurány 'település Bihar vm. D-i részén Belényestől DK-re, a Petrósz- Körös jobb partján' (<r. gurán 'süllo'); Kalugyer 'település Bihar vm. D-i határánál Nagykohtól D-re, a Fekete-Körös bal oldalán' (< r. călugăr 'szerzetes, barát, kalugyer'); Kerpenyét 'település Bihar vm. D-i határánál Belényestől DK-re, a Fekete-Körös partján' ( $<$ r. cărpinet 'gyertyán(fa)erdő, gyertyános'); Kristyor 'település Bihar vm. D-i határánál, a Fekete-Körös forrásvidékén' (<r. Criscior kicsinyítő képzős személynévből); Lonka 'település Bihar vm. D-i részén Rézbányától ENNyra, a Fekete-Körös jobb partján' (< r. luncă 'lanka, rét, árterület, völgyfenék, berek'); Pestere 'település Bihar vm. K-i részén Élesdtől D-re, a Sebes-Körös bal partján' (< r. peșteră 'barlang'); Pocsaveleste 'település Bihar vm. D-i részén Belényestől ÉK-re (< r. " pociovalişte 'marhák delelőhelye' < szl. počivaliste 'pihenőhely')

Másodlagos, származék földrajzi kölcsönelemeknek tekinthetők az olyan összetett településnevek, amelyeknek egyik eleme román eredetü, a másik eleme pedig régebbi magyar földrajzi köznév, és a név ilyen módon összetett szóként használatos. Az ilyen összetételek kialakulását példázzák a következő adatok: Albolfalva (< r. Albol személynév + falva); Alsópojény (< alsó + poieni [tbsz.] 'erdei, hegyi tisztás'; Barzafalva (< r. Barza, Borza családnév [Łbarză 'gólya'] + falva); Brajkuta (<r. Brai személynév + kútja); Dragánfalva $(<$ r. Drăgan személynév $[\leftarrow$ drăgan 'fejedelmi dragonyos']; Felsöszelistye $(<$ felsö + r. sălişte $\sim$ silişte $\sim$ selişte 'faluhely'); Floralaka $(<\mathrm{r}$. Flora 'személynév' + lak).

A visszakölcsönzés jelenségére még a földrajzi nevek körében is találunk példát. Nevét patakjáról, a Kenyérmezőnek is nevet adó Kenyér (feltételezett ómagyar ejtés szerint Kügyér)-patakról kapta. A név átkerült 
a románba és Cugir alakúvá vált, majd románosult formában került vissza a magyar nyelvbe (Reuter 1981). A Szeben megyei Orlát névalak szintén visszakölcsönzés eredménye. Az etimonja a feltételezhetően a vár alatt szószerkezet lexikalizálódott formája: *Váralatt > r. Orlat > m. Orlát.

A román földrajzi terminológia hatását figyelhetjük meg az olyan tü körszerkezetekben, amelyek a magyar földrajztudományban nem használatosak és román minta alapján keletkeztek fordítással, közvetett kölcsönzéssel: Nyugati-dombvidék 'Szilágysági-dombvidék, Körösvidékidombság és a Lippai-dombvidék együttes megnevezése' (r. Dealuriel de Vest); Kárpát-kanyar'a Keleti-Kárpátoknak az Ojtoz és a Prahova völgye által határolt déli része' (r. Carpații Curburii); Nyugati-Kárpátok 'az Erdélyi-Szigethegység, a Bánsági-hegyvidék és a Ruszka-havas együttese' (r. Carpații Occidentali); Vráncsa-hegység 'Háromszéki-havasok' (r. Munții Vrancei). ${ }^{37}$

Az erdélyi magyar településnevek kisebb hányada az erdélyi német (szász) nyelvváltozatból vezethető le. Ezek a településnevek a hagyományos szász tájegységekből származnak Szeben, Brassó, Fehér és Beszterce megyéből: Alcina < Alzen, Aldorf $<$ Wallendorf, Bendorf $<$ Bägendorf, Borberek $<$ Burgberg, Buzd < Bußd, Kálbor < Kaltbrunnen, Kerc $<$ Kerz, Moritzföld $<$ Moritzfeld, Akmár < Othmar férfinév, Nagysink Groß-Schenk, Rehó < Reichau, Ród $<$ Rod, Sellenberk < Schellenberg, Tohán $<$ Alttohan, Vecel $<$ Witzel, Völc $<$ Wölz, Zsiberk < Sigibirg Sigeberga női névből.

\subsection{Személynevek (családnevek) meghonosodása}

A személynevek körében elsősorban a családneveknél beszélhetünk román eredetü kontaktushatásról, jóllehet a magyar keresztnevek többsége közvetlen vagy közvetett kontaktus eredményeként keletkezett, a héber, a görög, a latin, a német, olasz, francia és más nyelvekből való kölcsönzéssel.

A román eredetű családnevek sokszínúségét, rétegezettségét jelzi, hogy tipologizálásuk számos szempont érvényesítését teszi szükségessé. Az alábbiakban az eredet, a meghonosodottság, az alakváltozatok, a gyakoriság, a régiség és a motiváltság szempontját vizsgálva elemzem a román eredetű családnevek nyelvészeti kérdéseit.

Mivel elvileg bármilyen román családnév átkerülhet a magyar nyelvbe a vegyes házasságból származó magyar anyanyelvűek révén, kérdéses, hogy ténylegesen milyen román eredetú családneveket tekintünk a magyar nyelv részének. Murádin László ezt a kérdést nyelvészeti alapon oldotta meg, és csak a magyarosan írt, hangalakilag módosult, a magyar nyelvi

\footnotetext{
${ }^{37}$ A földrajzi kifejezések meghatározását a Román-magyar földrajzszótárból vettem (SzékelyNagy 2009).
} 
hangszerkezetekhez idomult román eredetű családneveket vizsgálta ebből a szempontból az erdélyi családnév-monográfiájában (Murádin 2005). Jobb szempont hiányában én is ezt tartom követendőnek, és az általam összeállított román eredetű családnév-adatbázisban az ilyen természetü adatokat vettem fel..$^{38}$

A másik gond, hogy bizonyos nevek nemcsak román eredetünek tekinthetők, hanem más nyelvekből származóknak is. Ilyen például a Cserge családnév, amely magyarázható a románból vagy oszmán-törökből (délszláv közvetítéssel) (Zsemlyei 1995b: 108), sőt az Erdélyen kívüli területekről származó családnevekről az is elképzelhető, hogy a csörgő igenév cserge csörge alakváltozatából származnak (TESz; Bakos 1982); vagy a Dancs, amely román, görög vagy latin eredetünek egyaránt tekinthető ${ }^{39}$ Hasonlóképpen a Csoma családnév lehet olasz vagy oszmán-törökből származó, de a román eredet nem zárható ki, különösen, hogy az északkeleti nyelvterületen és Erdélyben a leggyakoribb (Hajdú 2010: 124). A Ráduly családnév esetében szintén valószínű a román származás kérdése, bár a nevet a szláv nyelvekből szokás származtatni a Rad Rada Rado apanévből (Hajdú 2010: 392). Erdélyi viszonylatban figyelembe veendő a román Radu név is, amely végartikulusos alakban Radulnak hangzik. Tudjuk, hogy számos román eredetű köznév -uj végződéssel honosodott meg az erdélyi nyelvváltozatokban (bácsuj, drákuj, fátuj, mutuj, prosztuj stb.) (Zsemlyei 1979: 192), olyannyira, hogy olyan román eredetü kölcsönszavak hangtestében is megjelenik ez a végződés, amelyeknél a hímnemü végartikulus hatását nem feltételezhetjük, lévén, hogy etimonjuk nőnemü (bikuj 'kapókövezés (játék)' < r. bică 'ua.', csorszuj 'elhasznált edényféle' < r. cioarsă 'ua.' stb.); tehát egyfajta, román eredetet jelölő képzővé vált a magyarban. Ezért azt mondhatjuk, hogy a Ráduly név -(u)j végződése szabályszerűen levezethetô román-magyar nyelvi érintkezés alapján is. Ugyanakkor azt is mérlegelnünk kell, hogy az említett szláv Rad névből származó nevek (Radics, Radó) első magánhangzója a lett, a Ráduly-nál pedig megőrződött az eredetinél hosszabban ejtett á fonéma. Másrészt azt is figyelembe kell vennünk, hogy Erdélyben több román eredetü családnév honosodott meg -uj vagy -uly $(<$ -ul) végződéssel: Barazsuly (< Baraju); Bárbuly (< Barbu, Barbul); Bercuj (<

\footnotetext{
${ }^{38} \mathrm{Az}$ adatbázis nevei részben az eddigi kutatások empirikus adataiból származnak (Fazekas 1995, Hajdú 2010, Murádin 2005, Zsemlyei 1995b), részben saját ez irányú kutatásaimból. Az adattár jelenleg 472 nevet tartalmaz. Az Erdély nevet tág értelemben használom, és magában foglalja a Partiumot is. A román családneveket Iordan (1983) és Graur (1965) monográfiájában ellenőriztem.

${ }^{39}$ Hajdú Mihály családnév-enciklopédiájában nem említi a román eredet kérdését, pedig több jel is utal erre: 1. Erdélyben a leggyakoribb, 2. az erdélyi magyar nyelvjárásokban elterjedt a román származású, 'piszkos; rendetlen' jelentésű dancs melléknév, 3. Többször előfordul a Dancs-Oláh összetételben, amint ez a Hajdú Mihály által szerkesztett enciklopédiából megtudható (2010).
} 
Berțu); Csucsuj (<Ciuciul); Dancsuj (<Danciu, Danciul); Danguly (<Danguli); Gosuly (< Goşoiu); Grávuj (< Greavu); Grekuj (< Grecu); Guczuj (< Guțu); Kurtuj (<Curtu, Curtul); Lupuj (<Lupu); Mitruly (<Mitrul); Moguly (< Mogoi); Nyáguly (<Neagu, Neagul); Paskuj (<Paşcu); Számszuly (<Samsu); Száouly (< Savu); Sztáncsuj (< Stanciu); Urszuj (<Ursuj); Viduj (<Vidu); Vojkuj (<Voicu); Zsunkuly (<Juncu). Végül az is jelzésértékü ebben a kérdésben, hogy Erdélyben a román eredetü családnevek körében a Ráduly bizonyult a leggyakoribbnak (Murádin 2005: 7). A többirányú nyelvi hatás lehetőségét figyelembe véve, és tekintettel az adott családnév erdélyi elterjedtségére, az adattárba felvettem a kettős vagy többes etimonú neveket is. Az ilyen vitatható eredetü nevek esetében sokat segíthetnek azok a névföldrajzi vizsgálatok, amelyek mennyiségi mutatókkal is jelzik egy adott régióban való elterjedtségét, lehetséges terjedési irányát. ${ }^{40}$

Amikor azt mondjuk bizonyos névről, hogy román eredetű Erdélyben, akkor ezzel csak az elsődleges átadó nyelvet nevezzük, és ez nem zárja ki, hogy a románban is kölcsönzéssel kerülhet, mint például a fentebb említett Ráduly, amely a románban szláv eredetü. Román eredetünek tekintjük azokat a névalakokat is, amelyeknek a másodlagos átadó nyelve a magyar, azaz visszakölcsönzéssel, módosult hangalakkal került újra a magyar névhasználatba. Ilyen családnevek a következők:

Avasán (Vasán) < r. Avaş(an) < m. (h)avas (i)

Csipkár <r. Cipcar 'csipkével kereskedö' < Cipke $(+-a r)<\mathrm{m}$. csipke

Fogolyán < r. Fogoian < fogoi $(+-a n)<\mathrm{m}$. fogoly

Gombár <r. Gombar 'gombaszedő, gombaárus' < gomba $(+-a r)<\mathrm{m}$. gomba ${ }^{41}$

Csizmár < r. Cizmar 'csizmakészítő, varga' < cizma $(+-a r)<$ m. csizma. ${ }^{42}$

Ezek az adatok azt jelzik, hogy a románban honosító képzőkkel integrálódtak hangalakilag az idézett magyar eredetü szavak, és ilyen módon váltak tulajdonnévvé. Mégis román eredetü családneveknek kell tekintenünk őket, hiszen a románban önálló fejlemény eredményeként alakult ki ez a morfémaszerkezetük, és valószínüleg a románban lettek tulajdonnévvé a megváltozott fogalmi jelentésüknek köszönhetően.

A román eredetű nevek hangalaki és lexikai integrálódásában fontos szerep jut a honosító funkciójú képzőnek, amely a román eredetü hangsorokat motiválttá teszi a nyelvérzék számára. Ilyen az -s névszóképző az

${ }^{40}$ Ilyen névföldrajzi adalékokkal szolgált a MMCsA adatbázisára támaszkodva Vörös Ferenc szóbeli közlése a Ráduly magyarországi téri tagolódásáról (MMCsA 2009). Eszerint megállapítható, hogy keleti irányból jött a név. A Dunától nyugatra csak nyomokban találni belőle. Budapesti gyakorisága pedig egyértelműen allogén népességre utal.

${ }^{41}$ Murádin 2005: 131-135.

${ }^{42}$ A DEX szerint a cizmă szó a románban magyar eredetű. 
Ordás (< urdă 'orda') és a Gusás (< guşă 'golyva') nevekben. Mivel a románban magyar képzőkkel analóg morfémák is vannak, az ilyen jellegű szóvégződések egy része a románban keletkezett. A Csimpolyás név példázza ezt, mivel ennél a névnél az -s képző megjelenése nem magyar külön fejlemény eredménye, hanem már a románban létre jött a románban is használatos -ş melléknévképzővel (cimpoiaş 'bőrdudás' $\leftarrow$ cimpoi 'bőrduda'). (Az -ş román melléknévképző analóg a magyar -s melléknévképzővel. A két képző viszonya további kutatás tárgya lehet.)

Teljes hangalaki integrálódásra utalnak azok a családnevek, amelyek annyira megmagyarosodtak, hogy hangalakjukban látszólag az idegenszerüség minden nyoma eltűnt, és akár a magyarban is keletkezhettek volna, mivel a szó végződésében bizonyos képzőket vélünk felismerni egyfajta belehallás eredményeként: Györgyice (< Gheorghiţă), Vaszi (<Vasile), Tanászi $(<\text { Tănase })^{43}$.

Zsemlyei János idézett tanulmányában (1995b) azt is vizsgálja, hogy a régi román eredetű családnevek román tulajdonnévből vagy köznévből erednek-e. Román személynévre vezethető vissza például Goga, Mircse, Mitruly, Ráduly, Vaszi; és köznévi eredetü többek között a foglalkozást vagy társdalmi státust jelölő: Bács, Berszán, Bo(j)ér. Ennél a kritériumnál az a probléma, hogy nem minden név esetében tudhatjuk egész biztosan, hogy románban kizárólag köznévként használták-e, és vajon nem volt-e személynévi funkciója is, hiszen a foglalkozásnevek számos nyelvben tulajdonnévvé válnak. Másrészt a szempont nehezen érvényesíthető jellegére utal, hogy számos olyan román eredetű családnévnek van román tulajdonnévi megfelelője, amelyek köznévi eredetünek tünhetnek: Boér, Cioban, Cojocar, Moldovean, Muntean, Mureşan stb. Alapos román nyelvtörténeti kutatásokra lenne szükség ahhoz, hogy a köznévi vagy a tulajdonnévi eredet kérdését érvényesíteni tudjuk, és valószínűleg így is maradnának bizonytalanságok, mivel nem minden név használata kellően dokumentált az elérhető román nyelvtörténeti forrásokban sem.

Nem egyszerú eldönteni azt sem, hogy a különböző nevek alakváltozatait mikor kell különböző neveknek tekintenünk, és mikor névvariánsoknak. Az egyetlen etimonra visszavezethető hangalakváltozatok egy névnek tekintendők-e, vagy pedig névváltozatoknak? Nem kérdéses, hogy a Sorbán Serbán Serbány (< r. Şerban) alakok egyetlen név variánsainak mondhatók, akárcsak a Marosán, Marozsán, Maruzsán, Morosán, Morozsán, Muresán (< r. Mureşan). De mégis a hasonló hangalakú neveket hogyan lehetne határozottan elkülöníteni, ha úgy tetszik, nem tartoznak feltétlenül össze? A leghasználhatóbb szempontnak az tünik, hogy akkor különböztessük meg a hasonló hangalakú neveket, ha azoknak etimonjai

\footnotetext{
${ }^{43} \mathrm{~A}$ Vaszi nevet a románok gúnyévként is használták (MTSz).
} 
különböző lexémákra vonatkoznak. A Dobricza és a Dobrila, külön családneveknek tekintendők, bár hangalakjuk csak egyetlen fonémában különbözik, mivel etimonjuk eltérő: a Dobricza a román kicsinyítő képzős Dobriţă alakból származik, a Dobrila pedig a hasonló hangalakú Dobrilă névből eredeztethető. Hasonlóképpen a Kozsok és a Kozsokár egyaránt román eredetű családnév, de az első a cojoc 'hosszú juhbőr bundából készült kabát' köznévből származik, a másik pedig a cojocar 'szürszabó, kozsokkészítő' szónak az átvétele. Az etimonok szófaji vagy morfológiai különbségei indokolttá teszik, hogy az ilyen esetekben két különböző névként tartsuk számon az azonos szócsaládból származó neveket. Ezért a lexikai vagy morfológiai különbségért kell lexikailag megkülönböztetnünk a következő neveket: Koszti (<Costin) - Kosztely (< Costei); Kriszte (<Cristea) - Krisztilyán (<Cristilean); Lupán (<Lupan) - Lupás (< Lupaş); Moga (<Moga) - Moguj $(<$ Mogoi); Pintya, Pintye (< Pintea) - Pintyuca (<Pintuța ); Triff $(<$ Trifu $)-$ Trifa $(<$ Trifa). A román családnevek alaki elemzése azt mutatja, hogy az etimonjukban kötött morfémát tartalmazó névalakoknál rendszerint a képzővel létrehozott származékokat kell elkülönítenünk, mivel a végartikulusos és a nem végartikulusos román név szemantikai és funkcionális szempontból ugyanazon lexéma variánsainak tekintendők: pl. Urszu $(<U r s u)-U r s z u j$ (<Ursul); Bács (< Baci) - Bácsu (< Baciu[l]); Dancs (< Danci) - Dancsuly (< Danciu[l]); Lupu (<Lupu) - Lupuj (<Lupu[l]).

Ritkán az is előfordulhat, hogy egy keresztnévi eredetü családnévnek több becéző alakváltozata családnévvé válik, mint például a Petru esetében: Petrás (< Petraş); Petre (< Petre); Petrikó $(<$ r. Petrică); Petruc $(<$ Petruț); Petruka $(<$ Petrucă); Petrus (<Petruş). Mivel itt a név alaki szerkezetében különböző kötött morfémákról van szó, ezeket a neveket külön-külön kellene számon tartanunk, és nem pusztán egyazon név hangalakvariánsaiként.

A családnevek gyakoriságának kérdése hasonlóképpen számos elvi probléma megoldását teszi szükségessé. A gyakoriság kérdése mindig fölveti a területiség szempontját is: milyen régióról mondhatjuk, hogy bizonyos családnevek a leggyakoribbak. Az említett családnevek enciklopédiájában megjelenő román eredetű családnevek (Argyelán $[<\mathrm{r}$. Ardelean $<$ r. Ardeal < m Erdély], Marosán, Moldován) a leggyakoribbak lehetnek Magyarországon, de ha Erdélyt is bevonjuk a vizsgált régiók körébe, akkor jelentősen módosulhat a leggyakoribb családnevek listája, amint ezt Vörös Ferenc tanulmánya is sejteti (Vörös 2010: 104-110.), amikor arra utal, hogy a három említett román eredetű családnévnek a gyakorisága a mai Magyarország keleti megyéiben a legmagasabb, ami Erdélyből jövő hatásra enged következtetni. A gyakorisági vizsgálatnak ki kellene terjednie olyan nevekre is, mint Berszán, Boér, Borbáth, Dobra, Koszta, Opra, Pop, mivel gyakoriságuk Murádin László szerint (2005: 79-90.) igen magas Erdélyben. 
Mindenképpen a családnevek gyakoriságát a magyar nyelvterület egészében kellene vizsgálni államhatároktól függetlenül, ha a magyar nyelvről akarunk valamit mondani, és nem kizárólag a magyarországi nyelvi helyzetről.

A románból származtatható családnevek arányára szociolingvisztikai értelemben nincsenek pontos adataink, de Murádin László ez irányú kutatásai, amely a fiatal korosztályra nézve megbízhatónak mondható, azt jelzik, hogy $9 \%$ körül van ezeknek az aránya a számba vett több mint négyezer családnév körében, és a vizsgált személyek 6,77\%-a visel bizonyíthatóan román eredetű vagy román nyelvből is származtatható családnevet (Murádin 2005: 136). ${ }^{44}$

A családnevek megterheltségének időbeli változás a olyan kérdés, amelyben a diakronikus perspektíva megkerülhetetlen vizsgálati szempont lehet a továbbiakban. Az eddigi névanyag elemzéséből megállapítható, hogy több régi, két-három évszázaddal korábban használt román eredetű családnév egy részére nincs mai adatunk, tehát lehetséges, hogy fokozatosan kiszorultak vagy kiszorulófélben vannak. Ilyenek a következő köznévi eredetü nevek: Arnót (< arnăut 'albán, makedóniai'); Cáp $(<$ țap 'bakkecske'); Csimpolyás (< cimpoiaş 'dudás'); Eszkotár (< scotar 'számadó juhász'); Fáta (< fată 'lány'); Gusás (< guşă 'golyva'); Guzsba (< gujbă 'szolgafa, szolgafakészítö'); Kaluger (< călugăr 'szerzetes'); Ordás (< urdă 'orda'); Pakulár (< păcular 'juhász, juhpásztor').

A tulajdonnevek jelentésének vizsgálatakor azt szokta a szakirodalom hangsúlyozni, hogy a tulajdonneveknek nincs fogalmi jelentésük (deszignátumuk), hanem csak konkrét jelöltjük (denotátumuk): az a személy, aki az adott nevet viseli (Péntek 1988). A nevek jelentős részére valóban ez jellemző, a jelentéstani-lexikai motiváltság eltünésével a hangalak opakká válik, és teljes mértékben önkényesnek tưnik. Ám ha az adott név köznévből vagy helynévből származik, és ez felismerhető a névben, akkor a szó jelentéstani értelemben motiválttá, áttetszővé válik a magyarromán kétnyelvüek számára azáltal, hogy a családnév alakjában felismerik a köznévi értelmet, és a névhez fogalmi jelentést is társíthatnak. Ilyenek például a foglalkozásra, a földrajzi régióra, emberi tulajdonságokra utaló jelentések. Román családneveket tartalmazó adatbázisomban a köznévből származó román tulajdonnevek arányát is vizsgáltam. A 472 névből 109 (23,72\%) bizonyult köznévi eredetűnek, fogalmi jelentést hordozónak, és ilyenként szemantikailag motiváltnak. A különböző jelentéskörök arányát az alábbi táblázat szemlélteti:

\footnotetext{
${ }^{44} \mathrm{Ha}$ a románosan írt neveket is figyelembe vesszük, akkor a román eredetü családnevek aránya 10\%-ot tesz ki Murádin László adattárában (2005: 131).
} 


\begin{tabular}{|l|c|c|}
\hline \multicolumn{1}{|c|}{$\begin{array}{c}\text { A szemantikailag motivált } \\
\text { családnév fogalmi jelentése }\end{array}$} & $\begin{array}{c}\text { Száma a román } \\
\text { eredetű családnévi } \\
\text { adatbázisban }\end{array}$ & $\begin{array}{c}\text { Aránya a köznévi eredetű } \\
\text { családnevek körében }\end{array}$ \\
\hline $\begin{array}{l}\text { Foglalkozás, társadalmi } \\
\text { státus }\end{array}$ & 41 & $37,61 \%$ \\
\hline $\begin{array}{l}\text { Testi, lelki tulajdonság, } \\
\text { emberi állapot }\end{array}$ & 24 & $22,01 \%$ \\
\hline $\begin{array}{l}\text { Földrajzi objektum (helynévi } \\
\text { eredetü) }\end{array}$ & 18 & $16,51 \%$ \\
\hline Növény & 12 & $11 \%$ \\
\hline Állat & 9 & $8,25 \%$ \\
\hline Nemzetiség & 3 & $2,77 \%$ \\
\hline Tárgy & 109 & $1,84 \%$ \\
\hline & & $100 \%$ \\
\hline Összesen & & \\
\hline
\end{tabular}

4. táblázat. Szemantikailag motivált családnevek

Amint a 4. táblázatból látható, a foglalkozást vagy társadalmi státust jelölő fogalom jelenik meg a legnagyobb arányban (37,61\%-ban) a szemantikailag motivált nevek körében: Ilyen nevek például: Bács(u) (<baci 'számadó juhász; juhos gazda'), Boér (< boier 'havaselvi vagy moldovai fö- vagy köznemes; fejedelmi darabont'); Czerán (<țăran 'paraszt, földmüves'); Csobán (< cioban 'juhász, juhpásztor' $\left.{ }^{\prime 45}\right)$; Csobotár (< ciobotar 'csizmadia'); Dászkel (< dascăl 'tanító'); Drumár (< drumar 'utász'); Kurtyán (< curtean 'zsoldos katona, udvaronc'); Pitár (< pitar 'pék'); Popa (<popă 'pap') stb. A testi vagy lelki tulajdonságra, emberi állapotra utaló fogalmi jelentések aránya a köznévi eredetü nevek körében 22,1\%-ot tesz ki, és olyan családnevek tartoznak ide, mint például a következők: Csoma (< ciumă 'pestis; alkalmilag: pestises'); Dancs (< danci 'piszok'); Fáta (< fată 'lány'); Gusás (< guşă 'golyva, gusás'); Kukuj (< cucui 'daganat'); Kurázs (< curaj 'bátorság'); Lung (<lung 'hosszú'); Mutra (< mutră 'arc, pofa'); Pozsár (r. pojar 'kanyaró, vöröshimlö'); Rinkács (r. rincaci 'rosszul herélt; komor'); Roskát (< roşcat 'vörös hajú'); Szermán (< sărman 'szegény, nyomorult') stb. Nem jelentéktelen a helynevekből, a földrajzi objektumok nevéből képzett családnevek aránya sem (16,51\%). Íme néhány adat ebből a jelentéskörből: Kluzsán (< clujean 'kolozsvári'); Kimpián (< câmpian 'alföldi, mezei'); Krisán (< crişan 'körösi'); Marosán, Morosán, Muresán (< mureşan 'marosi'); Mokán(y) (< mocan 'hegyvidéki'); Oltyán (<oltean 'olténiai'); Turgyán (< turdean 'tordai'); Moldován (< moldovean 'moldovai'); Muntean (< muntean 'havasalföldi'). Az állati vagy

\footnotetext{
${ }^{45}$ A DEX szerint a cioban a románban oszmán jövevényszó.
} 
növényi eredetű nevek aránya már jóval kisebb (8,22\%, illetve 2,77\%): Benzár (< bânzar 'bogár'); Berbécs (< berbeci [tbsz.] 'bakkecske'); Bondár (<bondar 'bogárfajta'); Lupuj (<lup[ul] 'farkas'); Urszu (< ursu 'medve' stb.) Vulpe (< vulpe 'róka'); Brád (< brad 'fenyő'); Brindus (< brinduş különböző növények neve); Burján (< burian' gyom'); Magureán (< măgură 'rügy'); Trándáfir (< trandafir 'rózsa'); Trufán (< trufan 'gomba'); Trunk (< trunchi 'fatörzs' $)^{46}$; Várza (< varză 'káposzta'). A következő három adat utal a nemzetiségre: Ármeán (< armean 'örmény'); Arnót (< arnăut 'albán, makedóniai'); Grekuj (< grec[ul] 'görög'). Tárgyi fogalmat jelölő köznévhez kapcsolódik a $M a$ csuka (< măciucă 'bot, bírói pálca') és a Csercse (< cercei [tbsz.]'fülbevaló, füljegy').

Más jellegü szemantikai motivációnak tekinthető a férfi keresztnévből származó családnevek. Ezekből 25-öt találtam a névállományban, ami a nevek 5,29\%-át jelenti. A következő nevekről van szó: Átyim (< Achim < Ioachim); Ávrám (< Avram); Bárbu (<Barbu); Estefán (< Ştefan); Gábrilla (< Gavrilă); Györgyice (< Gheorghiţă); Jánku (<Iancu); Januczás (< r. Ionuţaş); Marian (<Marian); Martin (<Martin); Mátei (<Matei); Mircse (<Mircea); Pável (< Pavel); Petrás (< Petraş); Petre (< Petre); Petrikó (< Petrică); Petruc (< r. Petruț); Petruka (< r. Petrucă); Petrus (< r. Petruş); Stefán (< r. Ştefan); Tanászi $(<$ Tănase); Toadér (< Toader); Valentin (<Valentin); Vaszi $(<$ Vasi[le]); Vlád (<Vlad).

Következtetésként elmondhatjuk, hogy a román eredetü családnevek vizsgálata több olyan elméleti kérdést vet fel, amelyeknek megoldása túlnő a vonatkozó adatok körén, és általános névtani és kontaktológiai kérdéseket is érint. A felvetett problémák egy részének megoldása további empirikus kutatásokat igényel.

\section{Betűszók átvétele}

A betüszókölcsönzés a közvetlen átvételnek egy sajátos formája, amely abban különbözik a tulajdonképpeni kölcsönzéstől, hogy az etimon az átadó nyelvben is több szó rövidítéséből keletkezett, így gazdag információtartalom és konkrétabb jelentésvonatkozás jellemzi. Különösen a szaknyelvekben gyakori (a természettudományokban talán még nagyobb mértékben, mint a társadalomtudományokban), de a közéletben is a hivatalos intézmények, a politikai pártok megnevezésekor érvényesül ez a rövidítési forma.

Amint láttuk, az erdélyi román-magyar kontaktusból származó lexikai adatok jelentős mértékben a hivatali és közéleti nyelvhasználat elemei. Gyakran pénzügyi és közgazdasági fogalmakat, állami vagy országos intézményeket jelölnek, és ezeket rendszerint a román nyelv szabályai sze-

\footnotetext{
${ }^{46} \mathrm{~A}$ moldvai Trunk településnévből is származhat.
} 
rint használják magyar nyelvi megnyilatkozásokban is, amint ezt a zárójelben feltüntetett ejtési változatok szemléltetik a következő adatokban: ANL (ánélé) 'Országos Lakásépítö-ügynökség' (<r. ANL: Agenția Națională de Locuințe); BCR (bécséré) 'Román Kereskedelmi Bank' (< r. BCR: Banca Comercială Română); BNR (bénéré) 'Román Nemzeti Bank' (< r. BNR: Banca Națională Română); CNSAS (csénészéászé) 'a Szekuritáte Irattárát Vizsgáló Országos Tanács' (< r. CNSAS: Consiliul Național de Studierea Arhivelor Securității); SEAP (széápé) 'közbeszerzések világhálós rendszere' (< r. SEAP: Sistemul Electronic al Achizitiilor Publice).

Ebben a kategóriában külön alcsoportot képviselnek a romániai politikai pártok román betűszóval jelölt megnevezései: $P D$ 'Demokrata Párt' (< r. PD: Partidul Democrat); PDL [pédélé] 'Demokrata-Liberális Párt $(<\mathrm{r}$. PDL: Partidul Democra Liberal) ; PNL [pénélé] 'Nemzeti Liberális Párt' (< r. PNL: Partidul Național Liberal) ; PNȚCD [pénécécsédé] 'Nemzeti Keresztény-Demokrata Parasztpárt' (< r. PNȚCD: Partidul Național Țărănesc Creștin și Democrat); PRM [pérémé) 'Nagy Románia Párt' (< r. PRM: Partidul România Mare); PSD (pészédé) 'Szociáldemokrata Párt'(< r. PSD: Partidul Social Democrat). Megjegyzendő a Romániai Magyar Demokrata Szövetség (RMDSZ) román betüszavas neve (UDMR [udéméré]: Uniunea Democrata Maghiara din Romania) magyar szövegekben is előfordul, de kizárólag stilisztikai célokból: a szerzők ironikus vagy gúnyos álláspontjának jelölésére, amint ezt az internetes szövegek, hozzászólások jelzik.

Több olyan román eredetü betü- vagy mozaikszó is használatos az erdélyi magyar szubstandard változataiban, amely az államszocializmus korábban keletkezett, de ma is felbukkannak általánosabb jelentésben vagy pedig retró szóként, egy lezárult korra történő utalási funkcióval: ADAS (ádász) '(volt) állami biztosítótársaság Romániában', ma: 'biztosító társaság' (<r. ADAS: Administrația Asigurărilor de Stat); aprozár 'zöldségesbolt' (<r. APROZAR: aprovizionare cu zarzavaturi); gosztát 'állami gazdaság' (<r. GOSTAT: gospodărie de stat); PCR [pécséré] 'Román Kommunista Párt' (<r. PCR: Partidul Comunist Român); UTC [utécsé] 'Fiatal Kommunisták Szövetsége' (<r. UTC: Uniunea Tineretului Comunist'ua.').

A román betűszó presztízsét nemcsak a romános ejtés jelzi, hanem az a tény is, hogy az erdélyi magyar sajtóban akkor is használják ezeket, amikor a betúszó által jelölt név jelen van magyarul. Ebben az esetben a román betűszónak egyértelműsítő funkciója van, mivel a román intézményneveknek gyakran többféle magyar fordítása van az erdélyi tömegtájékoztatási eszközökben. Ezt a jelenséget szemléltetik az alábbi mondatok: 
Forradalmi hangulatban zajlott a Romániai Gyáriparosok Egyesületének (román betüszóval UGIR) temesvári közgyülése a hét végén. ${ }^{47}$

Közleményében kifejti: az elmúlt időszakban kilenc lelkészröl derült ki, hogy együttmüködött a Securitatéval, 2008-ban pedig másik tizenhat papról derült ki ugyanez. Ez utóbbiak személyét a Securitate Irattárát Vizsgáló Tanács (CNSAS) azonosította-olvasható a dokumentumban. ${ }^{48}$

Egy sürgösségi rendelet értelmében, Románia Egészségügyi Minisztériumának hatáskörébe fog tartozni az Országos Egészségbiztosítási Pénztár (CNAS) koordinációjának irányítása a biztositás autonómiájának fenntartása mellett. ${ }^{4}$

Angol eredetü betüszók is megfigyelhetők a közéleti nyelvhasználatban. Ezek főleg nemzetközi intézményneveket jelölnek: NATO (North Atlantic Treaty Organization 'Észak-atlanti Szerződés Szervezete'), OPEC (Organization of Petroleum Exporting Countries 'Köolaj-exportáló Országok Szervezete'), IMF (International Monetary Fund 'Nemzetközi Valutaalap', UNICEF (United Nations International Children's Emergency Fund 'ENSZ Nemzetközi Gyermeksegélyzési Alap'). Az erdélyi informális internetes nyelvhasználat, a di gilektu s (Veszelszki 2013) mint egyfajta írott szlengváltozat számos angol eredetü betüszót alkalmaz: $B R B$ (be right back 'rövidesen visszatérek') DND (do not disturb 'ne zavarj'), LOL (laughing out loud v. lot of laugh 'hosszas nevetés'), OMG (Oh, my God! 'Ó, Istenem') (Homonai 2014, Szőcs 2012).

\section{Hangalakkölcsönzés, kölcsönhomonímia, visszakölcsönzés}

Amint szó volt róla, a hangalakkölcsönzés vagy alaki kölcsönzés olyan közvetlen kölcsönszót jelöl, amelynek hangalakjával analogikus viszonyban van egy hasonló hangalakú és jelentésü szó az átvevő nyelvben. Az erdélyi nem standard (rendszerint romándomináns) nyelvváltozatokban gyakran előfordul, hogy a beszélő az idegen szavaknak nem a köznyelvi alakváltozatát használja, hanem a többségi nyelv hatására utaló hangalakot, azaz szeminárium helyett szeminárt mond, vagy szklerózis helyett szklerozát. Ez a jelenség nemcsak az erdélyi magyar nyelvhasználatban figyelhető meg, hanem valamennyi Magyarországgal szomszédos, külső régióban (Katona 1995, Lanstyák 2005). Ezek a hangalakvariánsok olykor csak egy-egy hangban különböznek egymástól (pl. deszkriptív - deskriptív,

\footnotetext{
${ }^{47}$ http://archiv.nyugatijelen.com/2003/2003\%20augusztus/aug.\%2011\%20hetfo/j1.html [2013]

${ }^{48} \mathrm{http}: / /$ kozlony.unitarius.com/2010/uk2010-05.pdf [2013]

${ }^{49} \mathrm{http}: / /$ www.eski.hu/hol/cikkh.cgi?id=2680 [2013]
} 
inszpektor - inspektor), de a leggyakrabban az eltérő szuffixumokban (pl. ambíciós - ambiciózus, debil - debilis).

A hangalakkölcsönzésnek tekinthető direkt kölcsönelemek többségénél megfigyelhetö, hogy a román eredetü, az erdélyi nem standard nyelvváltozatokban jelentkező alakváltozatok sajátos, a magyar normatív köznyelvtől eltérő jellegét az okozza, hogy a románban az adott szóalakok francia közvetítéssel kerültek be, és így nem közvetlenül a görög vagy a latin szavakból, illetve szóelemekből származnak, mint a vele egyenértékü magyar standard változatú lexémák. A következő adatok a hangalakkölcsönzésnek ezt a sajátos esetét szemléltetik:

agronóm ( $<$ r. agronom $<$ fr. agronome) - agronómus (< lat. agronomus )

akcent $(<$ r. accent $<$ fr. accent) - akcentus (lat. accentus)

antibiotik $(<\mathrm{r}$. antibiotic < fr. antibiotique) - antibiotikum $(<$ lat. anti+biotikum)

báza $(<$ r. bază < fr. base) - bázis (< gör-lat. bassis)

delegát $(<\mathrm{r}$. delegate $<$ fr. délégué) - delegátus (< lat. delegatus)

deputát $(<\mathrm{r}$. deputat $<$ fr. député) - deputátus ( $<$ lat. deputato)

dialog $(<\mathrm{r}$. dialog $<$ fr. dialogue $)-$ dialógus $(<$ lat. dialogus $)$

dokument (r. document $<$ fr. document) - dokumentum ( $<$ lat. documentum) háosz (<r. haos < fr. chaos) - káosz (< gr. kháosz)

honorár ( $<\mathrm{r}$. onorar $<$ fr. honoraire) - honorárium ( $<$ lat. honorarius)

katalóg $(<$ r. catalog $<$ fr. catalogue $)-$ katalógus (< lat. catalogus).

Mindössze egy olyan adatot találtam, ahol az erdélyi alakváltozat és a köznyelvi variáns különbsége az elöljáró (prefixum) eltérő voltában ragadható meg: perfúzió (<r. perfuzie < fr. perfusion) - infúzió (< lat. infusion).

A hangalaki különbségek nemcsak az elsődleges átadó nyelv különbségével magyarázhatók, hanem az hangalaki meghonosodás eltérő módjaival. A következő alakváltozatok például az átadó nyelvként funkcionáló románban és a közmagyarban egyaránt francia eredetü, azaz közös a francia etimonjuk, mégis némileg eltérő az alakjuk: budzset $(<\mathrm{r}$. buget $<$ fr. budget) - büdzsé (< fr. budget); bufet (< r. buffet < fr. bufet) - büfé (< fr. bufet); bulevard $(<\mathrm{r}$. bulevard $<$ fr. boulevard $)$ - bulvár $(<\mathrm{fr}$. boulevard); garderoba $(<\mathrm{r}$. garderobă $<$ fr. garderobe) - gardrób ( $<$ fr. garderobe); doszár $(<$ r. dosar $<$ fr. dossier $)$ - dosszié (< fr. dossier). Ugyancsak közös etimonra vezethető vissza a jaurt (<r. iaurt) - joghurt hangalaki kettősége. A szó magyarban és a románban a török yoğurt etimonra utal, és a hangalaki különbség az integrálódás eltérő módozataival magyarázható. 
Az alaki kölcsönzés összefügg a hangalaki meghonosodás mozzanataival és az ehhez kapcsolódó szóteremtési eljárásokkal, valamint az közvetlen etimonok eltéró voltával: federális ( $<$ r. federal) - föderatív ( $<$ ném. föderativ); szponzorizál (< r. a sponzoriza) - szponzorál (< ang. sponsor).

Vitatható az olyan alakváltozatok ilyen szempontú összetartozása, amelyeknél a némileg különböző hangalakok eltérő jelentéssel társulnak, amint ezt a buletin - bulletin szavak viszonya jelzi. A buletin az erdélyi magyar nem standard, informális változataiban személyi igazolvány jelentésű $(<\mathrm{r}$. buletin [de identitate] 'személyi igazolvány'), míg a bulletin a köznyelvi idegen szóként 'közlemény, közlöny' értelmú. Bár mindkét szó a francia bulletin átvétele, a szó hangalakja és jelentése a románban megváltozott, és az erdélyi nyelvváltozatokba közvetlenül a románból került, és így ebben az esetben nem annyira alakváltozatokról beszélhetünk, mint inkább külön szavakról, mint a szóhasadás esetében. Ugyanez a helyzet a magyar köznyelvi patrónus 'pártfogó, védnök' és az erdélyi szubstandard patron 'tulajdonos, cégvezetö'. Itt is a szó végső forrása a latin mindkét nyelvben, de két különálló szótári egységről van szó, mintsem hangalaki kölcsönzésről.

Olykor a tudatos helyes nyelvhasználatra való törekvés túlhelyesbítéses alakokat is létrehozhat az aktív kétnyelvű beszélőknél egyfajta "magyarító" szándékból, és ez a hiperkorrekt forma kerül hasonlósági viszonyba a köznyelvi alakváltozattal: kompetenció $(\leftarrow$ r. competență $)-$ kompetencia; szupremáció (< r. supremație) - szupremácia.

A közvetlen kölcsönszavak sajátos esete az a szókölcsönzési forma, amelynek esetében az idegen szó hangalakja egybeesik egy létező köznyelvi magyar szóval, de a szó jelentése között viszont nincs kimutatható jelentés-összefüggés. Az ilyen átvételt kölcsönho moni mána k nevezhetjük. Az alábbi példák szemléltetik ezt a jelenséget: Er. komposztál '(lyukasztással) vonaljegyet kezel a buszon' ( $<$ r. a composta 'ua.') - komposztál 'komposztot állít elö'; Er. patron 'fónök, tulajdonos' (< r. patron 'ua.') - patron 'töltény', Er. masszív 'hegytömeg, őshegység' (r. masiv 'ua') - masszív '1. tömör; 2. nagy súlyú'..$^{50}$

\footnotetext{
${ }^{50}$ Kölcsönhomonímiára valamennyi kisebbségi magyar nyelvváltozatban találunk adatokat, amint ezt a Termini adatbázis jelzi: Va Hv Mv bambusz 'vörösborból és kólából álló italkeverék'; Va banya 'gyógyfürdö'; Va Hv biró 'iroda, ügynökség'; Mv dizel [dizel] 'sörből és kólából álló italkeverék'; Fv dressz 'konyhaszekrény mosogatója'; Óv drukker 'számítógép nyomtatója'; Fv fix 'filctoll'; Va koncert 'takarmánykeverék'; Ovv kuli 'golyóstoll'; Fv lista 'keskeny léc'; Va Hv patika 'edzőcipő, tornacipő'; Va, Hv poén 'pont mint a teljesítménymérés eszköze'; Fv polozska [poloska] '(könyvvitelben) tétel, bejegyzés'; Fv privát 'albérlet'; Mv trák 'fülvédö'.
} 
A visszakölcsönzés terminus a metaforikus megnevezésen túl jelzi a kontaktusfolyamatnak azt a kétirányúságát, amelynek következtében az átvett lexikai elem visszakerül az átadó nyelvbe, rendszerint módosult hangalakban, amint az alábbi adat ezt szemlélteti:

m. perzsel, pörzsöl > r. pîrjoli 'avart éget' > m. nyj. pirzsolál 'ua.'

A legtöbbször azonban nemcsak a hangalak módosul, hanem a jelentés is: a románba átkerült szó jelentése módosul, és az ilyen módon a románban meghonosodott szó a megváltozott denotatív értékével kerül vissza a magyarba, amint ezt a borkán kölcsönszó „,története' jelzi:

m. borkanna > r. borcan 'beföttesüveg' > Er. m. borkán 'beföttesüveg'

Olykor a visszakölcsönzés folyamata kettős jelentésváltozással jár együtt: az átvevő nyelvben is módosul a szó jelentése, és az átadó nyelvbe visszakerülve szintén némileg megváltozik a szó fogalmi köre:

m. hordó > r. hîrdău 'hordó; túrós bödön; faedény' > m. hurduj 'vajköpülő fadézsa'

m.nyj. szigorú 'gyenge, sovány, fejletlen' > r. jigăraie 'izomgörccsel járó kutyabetegség' > m. zsigodiás 'gyenge, merevlábú (tavaszi csirke)'.

A közvetlen nyelvi hatás tehát nemcsak köznevek átvételét jelenti, ami a lexikai érintkezés tipikus esete, hanem a földrajzi és személynevek, betüés mozaikszók, valamint hangalaki kölcsönzést. 


\section{KÖZVETETT (INDIREKT) KÖLCSÖNZÉSEK}

A nyelvi érintkezések lexikai vizsgálatában a legtöbb elemzés a közvetlen (direkt) átvételekhez, az új hangalakokhoz kapcsolódó jelenségeket veszi számba, és csak kisebb mértékben foglalkozik a közvetett (indirekt) nyelvi érintkezések olyan formáival, mint a tükörszó-, tükörszerkezet- és jelentéskölcsönzés. Ez egyrészt azzal magyarázható, hogy a közvetett nyelvi érintkezések kevésbé feltűnőek, mint az idegen vagy szokatlan hangalakok megjelenése egy adott nyelvváltozatban, másrészt, mert sokkal kevesebb adat áll a kutatók rendelkezésére erről a területről.

Mint ismert, a közvetett átvétel megnyilvánulhat jelentéskölcsönzésben, tükörszavak és tükörkifejezések használatában (Lanstyák 2006, Benő 2008). ${ }^{51}$

\section{Jelentéskölcsönzés}

A jelentéskölcsönzés folyamata összefüggésben van az etimon többértelműségével, hiszen a jelentéskiterjesztés olyan módon történik, hogy az átvevő nyelvben a szó jelentése egy vele ekvivalensnek minősített más nyelvi jel többértelmű jelentésszerkezetének mintájára lesz használatos. Jó példa a jelenségre az órarend 'nyitvatartás' értelemben való használata Erdélyben (a román orar [1. 'órarend'; 2. 'nyitvatartás'] poliszém alak hatására), illetve a felvidéken lejegyzett széles melléknév 'bő' jelentésben való megjelenése a szlovák a 'bő' és 'széles' jelentősű šroký melléknév hatásának eredményeként (Lanstyák 1998: 44).

\footnotetext{
${ }^{51}$ Amint az elméleti fejezetben szó volt róla, a hibridszerkezetek külön kategóriát alkotnak, mivel direkt (idegenszó-kölcsönzés) és indirekt nyelvi hatás (tükörfordítás) egyszerre érvényesül bennünk.
} 
A másol ige az erdélyi iskolai nyelvhasználatban 'puskázik', 'csal az írásbeli vizsgán' jelentésű a r. a copia 1. 'másol', 2. 'puskázik' ige jelentésbesugárzásával magyarázhatóan, amint ezt a Termini szótár szócikke példamondataival is szemlélteti:

másol (ált) (közh) (köz) 'puskázik, csal az írásbeli vizsgán': Számon kérés alatt másolni, súgni vagy bármiféle nem tisztességes jegyszerzési módszert alkalmazni: olyan tevékenységeket folyatni, melyek hazugságot, csalást, tolvajlást, megfélemlitést, zsarolást, vagy más, a Büntetö-törvénykönyv által is elítélt cselekedetet feltételeznek. (www.refkoll.ro) Er A Realitatea hír-csatorna információi szerint Bukarestben a román nyelv és irodalom érettségi dolgozatokat javitó tanárok több tíz egyforma megoldást is találtak, amiböl arra következettek, hogy a diákok másoltak. A tanárok jelezték az ügyet a tanfelügyelőségen. (www.impulzus.ro)

A Termini-adatbázis több adata is jelzi, hogy a román eredetű jelentéskölcsönzéseknél rendszerint az etimon származékjelentésének besugárzásával van dolgunk, amint az alábbi igei és fônévi adatok ezt mutatják:

felcsenget (ált) (közh) (biz) 'telefonon felhív'. Er Most egy éve vásároltam egy használt, de jó állapotú mosógépet. Mostanig fungált, de amikor táncolni meg dübörögni kezdett, azonnal felcsengettem az eladót, de azt mondta, hogy nem tudnak kiszállni. (www.szekelyhon.ro) (<r. a suna'1. csenget, 2. 'felhív')

jel (ált) (közh) (köz) 'térerö': Nincs jel, és a telefonon senkit nem tudok innen hívni. (f.n.) (< r. semn 1. 'jel', 2. 'térerö')

megvalósítás(ált)(közél)(köz)'eredmény':Szerencsében, megvalósitásokban gazdag,boldogújévetkívánunkmindenkedvesolvasónknak!(www.nagybanya.ro). A torjaiönkormányzat idén is eredményes évet tudhat maga mögött, megvalósitások hosszúlistájáról számoltbe dr. Daragus Attila polgármester. (www.hirmondo.ro) $(<$ r. realizare 1 . 'megvalósítás', 2. 'eredmény').

tevékenység (isk) (közél) (köz) 'rendezvény, bemutató, akció': A kézdivásárhelyi polgárközeli rendőrség és a berecki rendőrörs kedden a müvelődési központban bünmegelözési tevékenységet szervezett. (www.3szek.ro) (< r. activitate 1. 'tevékenység', 2. 'rendezvény').

vonal (id+isk) (szak+közél) (biz) '(nyelvi) tagozat (rendszerint egyetemen)': Miközben a rektori hivatal közleménye szerint a javaslat ellen mindössze kilencen szavaztak, mellette pedig a román és a német vonal, a judaisztikai kar valamennyi képviselöje, valamint a magyar vonalat képviselök többsége, a Krónika értesülései szerint a szankciót tulajdonképpen három magyar egyetemi tanár támogatta (www.nagybanya.ro) (<r. linie 1.'vonal', 2. 'tagozat').

vonalka (id) (közh) (biz) 'kötőjel': Szóköz megengedett, irásjelek nem - kivéve zárójelek, vonalka és alulvonás. (www.mikola.ro) (<r. liniuță'ua'). 
Külön kezelendők azok az adatok, amelyek csak a romándomináns kétnyelvü beszélőknél jelentkeznek. Ebbe a körbe tartozik az ül és az áll román modell szerinti jelentéskiterjesztése:

ül (id+nép) (közh) (kissébiz) 'valaki valahol rendszeresen tartózkodik': A fönök a 3-as szobában ül. (f.n.) (r. a sta 1. 'ül', 2. 'tartózkodik').

áll (az ágyban) (id) (közh) (biz) 'fekszik (az ágyban)': Anyanyelvi konferencián mesélte az egyik résztvevö, hogy egy szórványvidéki faluban hangzott el a következö mondat: "Tegnap nem még bírtam felkelni, egész nap mind álltam az ágyban." (archiv.nyugatijelen.com) (r. a sta 1. 'állni', 2. 'feküdni').

Ezek az adatok arra is utalnak, hogy az azonos fogalmi jelentésű államnyelvi lexémák származékjelentései mintaként szolgálhatnak bizonyos magyar szavak újabb jelentésértékben való használatára. (A többségi nyelvi hatás szemantikai vonatkozásairól 1. Benő 2007, 2009.)

\section{Tükörszó}

A tükörszók, amint szó volt róla, abban különböznek a jelentéskölcsönzéstől, hogy itt nem már létező szavakhoz rendelődnek újabb jelentések, hanem fordítással új összetett vagy származékszók keletkeznek az átadó nyelv minta alapján, amint a következő adatok szemléltetik ezt: családorvos 'háziorvos', iskolacsoport 'iskolaközpont' (< r. grup școlar 'ua.'); közköltség 'társasház rezsiköltsége' (< r. cheltuieli comune 'ua.'); küldốcédula 'beutaló' (<r. bilet de trimitere 'ua.'), munkarégiség 'szolgálati idő' (<r. vechime în muncă 'ua.').

\section{Tükörkifejezés}

A tükörkifejezések (tükörszerkezetek) fordítással keletkezett két vagy több szóból álló szószerkezetek (szintagmák) vagy nagyobb szintaktikai egységek, amelyek az átadó nyelvi szerkezettel az alkotóelemek és az összjelentés tekintetében is megegyeznek. Ezeknek az etimonja általában az átadó nyelvben is szintagmaszintű nyelvi egység. A legtöbb ilyen tükörkifejezés az erdélyi magyar nyelvváltozatokban jelzői szószerkezet: anyasági segély 'az anyasági szabadság idejére járó segély; gyermekgondozási segély' (< r. ajutor maternal 'ua.'); családi orvos 'háziorvos' (< r. medic de familie 'ua.'); egészségügyi könyv 'egy adott háziorvoshoz való tartozást jelző igazolvány, amelybe a tulajdonosának krónikus megbetegedéseit bejegyzik' (< r. carte de sănătate 'ua.'); közös törzs 'törzsanyag (a felsőfokú oktatásban)' (<r. trunchi comun 'ua.'); munkahelyi régiség 'szolgálati idö' (< 
r. vechime la locul de muncă 'ua.'). Viszonylag kevés az igei alaptagú, tükörfordítással keletkezett szószerkezet: pontra tesz 1. 'rendre utasít', 2. 'rendbe szed, elrendez' (< r. a pune la punct 'ua.'), telefont ad 'telefonál' (<r. a da telefon 'ua.'), veszi a vizsgát 'sikeresen vizsgázik' (< r. a lua examenul).

Külön csoportba sorolandók az olyan igei tükörkifejezések, amelyek szinte kizárólag romándomináns, aktív kétnyelvü beszélők megnyilatkozásaiban jelentkeznek. Ilyenek például a csinál igével alkotott kollokációs szószerkezetek, amelyek azonos jelentésü, román köznyelvi mintákra, szokványos szerkezetekre vezethetők vissza: infarktust csinál 'szívinfarktust szenved' (< r. a face infarct 'ua.'); lázat csinál 'belázasodik' (< r. a face febră 'ua.'); tüdőgyulladást csinál 'tüdőgyulladást kap' (< r. a face pneumonie 'ua.'). Valószínüleg szintén a romándomináns népnyelvi beszélőknél jelentkeznek olyan kollokációs tükörszerkezetek, mint a megüti az álom 'elálmosodik' (r. îl lovește somnul 'ua.'), virág a fülnek 'semmiség' (r. floare la ureche 'ua.') (Péntek 2001: 98). De ez a jelenség érintkezik a frazémakölcsönzés folyamatával.

\section{Frazémakölcsönzés}

Román mintára kialakult közmondások és szólásokra viszonylag kevés adatunk van. Ám azokban az erdélyi magyar régiókban, ahol erőteljesnek, intenzívnek mondható a román hatás nyelvjárási szinten elterjedhetnek fordítással keletkezett frazémák. Ezt igazolják Horváth István Magyarózdról írott néprajzi monográfiájának ilyen természetü adatai: perzsel ahun elmenyen 'ellop, amit megfoghat' (< r. arde pe unde trece 'ua.'), ügyelj, me kiveszen az eszedból 'vigyázz, mert elcsábít' (< r. te scoate din minți 'ua'), nekem nem csudám 'engem nem bosszant' (<r. nu mi-e ciudă 'ua.').

\section{A közvetett átvételek és a nyelvváltozatok összefüggése}

Ha arra vagyunk kíváncsiak, milyen nyelvváltozatban, regiszterben jelentkezik nagyobb arányban a közvetett államnyelvi hatás, akkor azt láthatjuk a korábbi kutatások és a Termini-adatbázis adatai alapján, hogy ezek leginkább a hivatali, közigazgatási szókincsben és a szaknyelvi változatokban fordulnak elő nagyobb mértékben, akárcsak a közvetlen kölcsönszavak.

A hivatali, közigazgatási regiszterbe sorolható az intézmények nevei, adminisztratív terminusok, az ügyintézés és pénzügy általánosan ismert fogalmait jelölő szavak, kifejezések. Ebben a nyelvváltozatban az indirekt kölcsönzés mindhárom alapformájára (a jelentéskölcsönzésre, tükörszóra és a tükörszerkezetre) találunk adatokat. 
A jelentéskölcsönzés ebben a regiszterben főnévi, igei és melléknévi alakban egyaránt megtalálható. Ezt jelzik az alábbi, hiteles forrásokból származó lexikográfiai adatok:

régiség (ált) (közél) (köz) 'szolgálati idő'. A szakszervezeti vezetô azt is hozzátette, hogy azok a BCR-alkalmazottak, akiknek 1 vagy 2 év régisége van, majdnem kétszer akkora fizetést kapnak, mint azok, akiknek nagyobb a régiségük, bár ugyanazt a munkát végzik. (www.impulzus.ro) (r. vechime'ua.')

letesz ts ige: 1. (nép) (hétk) (biz) bead (hivatalos iratot). A kérvényt le kell tenni a hónap végéig. 2. (nép) (hétk) (biz) befizet. Nem tette le a megajánlott pénzt. (Zsemlyei 1995a: 250) (r. a depune'ua.').

aláír (id) (sajtó) (biz) 'valaki valaminek a szerzője': A következő jegyzetet K. D. kollégám írja alá. (Zsemlyei 1995a: 249) (r. a semna 'ua.')

kiír (ált) (hétk) (köz) 'gyógyszert felír': Ezért a következôt kellett tennem: 15 ezer lejért Nagykárolyba utaztam, a szakorvosnak fizettem 200 ezer lejt, a véleményezés birtokában 15 ezer lejért hazautaztam Gencsre a háziorvoshoz, aki kiirta a gyógyszert, újabb 15 ezer lejért ismét Nagykárolyba utaztam, 200 ezer lejes kedvezményes áron kiváltottam a gyógyszert. (www.hhrf.org/frissujsag) (r. a prescrie [medicament] 'ua.')

sürgősségi (ált) (közh) (köz) 'katasztrófával kapcsolatos': sürgősségi helyzet 'katasztrófahelyzet'(r. situaţie urgență 'ua'.).

A hivatali nyelvezet, a közéleti regiszter tükörkifejezései között igen nagy arányban fordulnak elő az oktatás és az egészségügy köréből származó, államnyelvi mintára keletkezett szószerkezetek (szókapcsolatok), amint az alábbi, példamondatos adatok jelzik:

anyasági segély (ált) (közh) (köz) 'az anyasági szabadság idejére járó segély; gyermekgondozási segély': A családi pótlék, GYES, GYED, anyasági segély, közgyógy-igazolvány használatához társadalombiztosítási kártya szükséges. (itthon.transindex.ro) (r. ajutor maternal 'ua')

egészségügyi központ (ált) (közél) (vál) 'rendelőintézet': Április 12-én, szombaton Böcskei László, a Temesvári egyházmegye általános helynöke szentelte fel Csákon a németországi adományokból felépitett Szent Ilona Egészségügyi Központot. (www.nyugatijelen.com) (r. centru de sănătate 'ua')

fertôző betegségek kórháza (ált) (közh) (köz)'járványkórház': A szaktárca ajánlása szerint a betegség terjedésének megelózése érdekében a beteg egyeztessen egy olyan vizsgálati idôpontot a családorvosával, amikor más már nem tartózkodik a családorvosi kabinetben. Ha ez nem oldható meg, akkor a betegek jelentkezzenek a fertözó betegségek kórházainak ügyeleti szobáinál - adta ki az egészségügyi minisztérium. (www.szekelyhon.ro) ( r. spital de boli infecțioase 'ua.') 
fizikai személy (ált) (közh) (köz) 'természetes személy', 'magánszemély': Személyes jellegü adatok: minden olyan információ, amely segítségével egy fizikai személy azonosítva van, illetve azonositható közvetlen vagy közvetett módon. (www.manna.ro) (r. persoană fizică 'ua.').

nemzeti út (id) (közél) (biz) 'országút': Szászrégenen áthaladnak a 15-ös nemzeti út (Marosvásárhely-Szászrégen-Maroshévíz), a 16-os nemzeti út (Szászrégen-Kolozsvár), a 16A nemzeti út (Szászrégen-Beszterce), valamint Görgényszentimre, Laposnya, Görgénysóakna, Alsóidecs, Dedrád, Bátos felé vezető megyei utak. (www.primariareghin.ro) (r. drum național 'ua.').

A közéleti nyelvhasználatban a tükörfordítás a többelemű tulajd onnevek szintjén is érvényesülhet, elsősorban az intézménynevek körében:

Megyei Sürgósségi Kórház (ált) (közh) (köz) 'megyei baleseti kórház': A megyei egészségbiztositó pénztárral tavaly kötött szerződésünkhöz képest az idénre elöirányzott összeg 17\%-kal volt kevesebb - mondta dr. Demeter Ferenc, a csíkszeredai Megyei Sürgősségi Kórház menedzsere. (www.honline.ro) (r. Spital Județean de Urgență 'ua.')

Sürgốsségi Helyzetek Felügyelôsége (ált) (közél) (köz) '(megyei szintű) katasztrófavédelmi hivatal': Négy Volvo alapra épitett tủzoltósági autót adtak át Kovászna Megyei Sürgősségi Helyzetek Felügyelőségének (www.figyelo.ro) (r. Inspectoratul pentru Situații de Urgentă 'katasztrofavédelmi felügyelóség').

Szállításügyi Minisztérium (isk) (sajtó) (köz) 'Közlekedési Minisztérium': Tánczos ígérete szerint a Szállitásügyi Minisztérium állja majd az új erdők telepitéséhez szükséges összeget. (www.transindex.ro) (r. Ministerul Transporturilor'ua.').

Kettős kontaktusjelenség is érvényesülhet egy-egy tükörszerkezetben. A szószerkezet valamelyik elemében jelentéskölcsönzést állapíthatunk meg, miközben a szerkezet egésze nyilvánvalóan fordítással keletkezett. Ezt példázza a következő adatsor:

környezetvédelmi gárda (szak+közél) (köz) 'környezetvédelmi felügyelöség': Azt is megtudtuk, hogy Alexandrescu Nicolae a környezetvédelmi gárda felügyelöje, egy egész szombati napon a helyszínen volt, s figyelmeztette az embereket a tisztaság megörzésére. (www.erdely.ma) (r. garda de mediu 'ua.') 
Mint tudjuk, a magyar köznyelvben a gárda szónak nincs felügyelőség vagy hivatal jelentése. ${ }^{52}$ Tehát szószinten jelentéskölcsönzésről beszélhetünk, ugyanakkor a szerkezet egésze mégiscsak tükörszerkezetnek tekinthető. (Hibridszerkezetnek nem mondhatjuk, mivel új idegen szót nem tartalmaz a jelzős szószerkezet.)

A szaknyelvekből származó közvetett hatásra is találunk adatokat a Termini-adatbázisbanm mind a jelentéskölcsönzésre, mind a tükörszerkezetekre. Íme, néhány lexikai adat az ilyen jellegü jelentéskölcsönzésre:

vonal Er (id+isk) (szak+közél) (biz) (nyelvi) 'tagozat (rendszerint egyetemen)' (r. linie 'ua')

meditálás(fn)(id)(szak+szleng)(kissébiz)'óraadás': Mire tizenkettedikbekerültünk, mi isolvasókkáváltunk, ismertükarománirodalomtörténetet. Abbanazidóbennemvoltdivatameditálás, csakazórántanulhattunk.(archiv.nyugatijelen.com) (r. a medita la... 'magán órát ad valamiből')

órarend (ált) (közh) (köz) 'munkálatok, szolgáltatások időbeosztása': A vizszolgáltatás kérdése Uzonban továbbra is rengeteg fejtörést okoz, mind a fogyasztóknak, mind az önkormányzatnak, a felhalmozódott adósságok miatt az ivóvíz-szolgáltató (Termocom Rt.) csupán egy "vékonyka" órarend szerint dolgozik: reggel 7 és 9 óra között, délután 17-tól 22 óráig folyik víz a csapokból; hétvégén a szolgáltatás 24 órás. (www.szekelyhirmondo.ro) (r. orar 1. 'órarend', 2. 'szolgáltatások időbeosztása').

promóció (id) (szak) (biz) 'ugyanabban az évben, ugyanazon a szakon végzett egyetemi hallgatók csoportja': Erre abból az alkalomból került sor, hogy Nyárádszeredán végzett a Kertészeti Egyetem első promóciója, és az idei tanévben 110 hallgató kezdi meg ebben az oktatási központban föiskolai tanulmányait. (www.hhrf.org/rmdsz) (r. promoție'ua.').

Kisebb mértékben, de az erdélyi nyelvjárásokban is megfigyelhető a román eredetű tükörszók érvényesülése. Péntek János etnobotanikai kutatásai során arra figyelt fel, hogy számos tükörszerkezet található a népi terminológiában (Péntek 2001: 17). Ilyen a disznóserte (< r. părul porcului, szó szerinti jelentésben: 'a disznó szőre', 'Nardus stricta') és a farkascserge ( $<$ r. țolu lupului 'farkastakaró', azaz 'Polypodium vulgare').

Az erdélyi magyar szaknyelvi regiszterekben jelentkező tükörkifejezéseket adatolják a következő szerkezetek:

\footnotetext{
${ }^{52}$ Tolcsvai Nagy Gábor Idegen szavak szótára a gárda szónak a következő jelentéseit tartja számon: 1 . 'fegyveres testület', 2. 'katonai egység', 3. 'fegyveres karhatalmi testület', 4. 'társadalmi szervezet vezetősége', 5 . 'munkacsapat'.
} 
elszigeteltségi pótlék (id) (szak)'(pedagógusoknak fizetett) területi pótlék': Az egyezségben szerepel: a tanügyminisztérium december 1-jétől kezdődően kiosztja az újraszámolt elszigeteltségi pótlékot (archivum.szabadsag.ro) (r. spor de izolare 'ua.').

hosszú fény (ált) (szak) (biz) 'reflektorfény, országúti fény': Azt hiszem, mindannyian ismerjük azt a tévhitet, miszerint ködben a legideálisabb a reflektort (hosszú fény) használni. (www.szatmar.ro) (r. fază lungă 'ua.').

nemzeti vizsga (id) (szak) (biz) (ritk) 'nyolcadikosok országos írásbeli vizsgája': Nemzeti vizsga nyolcadikosoknak - didaktika. (www.didaktika.ro) (r. test național 'ua').

rövid fény (ált) (szak) (biz) 'tompított fényszóró': Többen kaptak bírságot azért, mert elmulasztották a rövid fény nappali használatát. (szekelyhon.ro) (r. fază scurtă 'ua.').

A hivatali, közigazgatási és a szaknyelvi regiszterekből származó közvetett lexikai hatás azt jelzi, hogy azokban a nyelvi változatokban a legerősebb a többségi nyelv hatása, ahol az anyanyelvi használata kisebb vagy nagyobb mértékben korlátozott, és így az aktív kétnyelvű beszélők nyelvtudásában ezeken a nyelvhasználati színtereken az államnyelvi terminus a gyakoribb, amelynek következtében a többségi nyelvi szerkezet nyoma akkor is megnyilvánul, amikor az adott fogalmat lefordítja, azaz magyar szavakkal nevezi meg.

\section{A tükörszerkezetek formális-szerkezeti sajátosságai}

Ha a közvetett kontaktusjelenségek vizsgálatát kiterjesztjük valamenynyi külső régióra, akkor formális-szerkezeti szempontból azt láthatjuk, hogy összehasonlítva a magyarországi standardban használatos egyenértékű párjukkal, analitikus-szintetikus különbségek mutatkoznak, azaz a többségi nyelvek gyakran széttagoló szerkezettel, több szóval fejeznek ki olyan fogalmakat, amelyekre a magyar köznyelvben egyetlen szóval kifejezhető, amint az alábbi kalkok ezt szemléltetik:

bevásárlási központ Er, Fv 'bevásárlóközpont'

egészségügyi nôvér (Er, Fv) 'ápolónő' (r. soră sanitară'ua.'; szlk. zdravotná sestra 'ua.'

elméleti líceum (Er) 'gimnázium' (< r. liceu teoretic 'ua.')

fertőző betegségek kórháza (Er) 'járványkórház' (< r. spital de boli infecțioase 'ua.)'. 
Akár „költői”-nek tűnő, analitikus megnevezések is meghonosodhatnak tükörfordítás eredményeként. Ilyen a 'szolgálati idő' jelentésü régiség a munka mezején kifejezés az erdélyi nyelvhasználatban. A tükörszerkezet elterjedtségére, stílusértékbeli jelöletlenségére utal az a tény, hogy írott nyelvváltozatban is előfordul, amint az alábbi, élőnyelvi példamondat jelzik: És akkor elkezdtem gondolkozni, hogy végül is, amit én az egyetemen tanultam, meg a 20 év régiségem a munka mezején termelésból vagy irodai munkában, amit eltöltöttem, úgy gondolom, hogy felhatalmasít arra, hogy próbálkozzak és teremtsek én magamnak munkahelyet. (www.objektiv.ro)

Ismert, hogy a magyar nyelv szintetikusabb jellegü a szláv és a neolatin nyelvekhez képest, amelyekben erőteljesebbek az analitikus (széttagoló) vonások. A korábbi szociolingvisztikai felmérések azt jelezték, hogy kisebbségi magyar nyelvváltozatokra nagyobb mértékben jellemző az analitizálódás, az analitikus szerkezetek preferálása a morfológiai szerkezetükben különböző nyelvi változók esetében (tagdíj-tagsági dijj, szépitkezik - szépiti magát) (Göncz 1999: 173-75). Ez a relatív kontaktusjelenség és a kalkok alkalmazása egyaránt az analitizálódás terjedésének kedvez.

\section{Tükörszerkezet vagy megőrzött régiség?}

Nem mindig magyarázhatóak a kisebbségi nyelvváltozatok sajátos lexikai elemei a többségi nyelv közvetett hatásával. Olykor a mai magyarországi köznyelvtől eltérő szavak, kifejezések megőrzött régiségek is lehetnek, különösen, ha a több külső régióban is használatosak, és jelentésük közismert általában magyar anyanyelvű beszélők számára. Ezt sejtetik az alábbi két szócikkben megjelenő adatok:

születési bizonyítvány (Er) (ált) (közh) (köz), Fv (ált) (közél) (kissé vál), Ka (ált) (közh) (köz) születési anyakönyvi kivonat

halotti levél (Er) (nép) (hétk) (biz), Fv (ált) (közél) (köz), Va, Ka (nép) (közél) (kissé biz) halotti anyakönyvi kivonat

Első látásra azt gondolnánk, hogy ezek államnyelvi mintára létrejött tükörkifejezések, de ha figyelembe vesszük a korábbi nyelvhasználatot is, akkor kételkedni kezdünk ebben a feltételezésben. Illyés Gyula 1936-ban megjelent Puszták népe című szociográfiai művében előfordul a születési bizonyitvány megnevezés: „Újabb irodalomtörténészeink szemében kitűnő ajánlólevél a Dunántúlról kelt születési bizonyítvány." Másrészt könnyen kinyomozhatjuk, hogy a 19. században és korábban így nevezték ezt az iratfajtát, amint az alábbi 1884-ből származó dokumentum képe jelzi: 


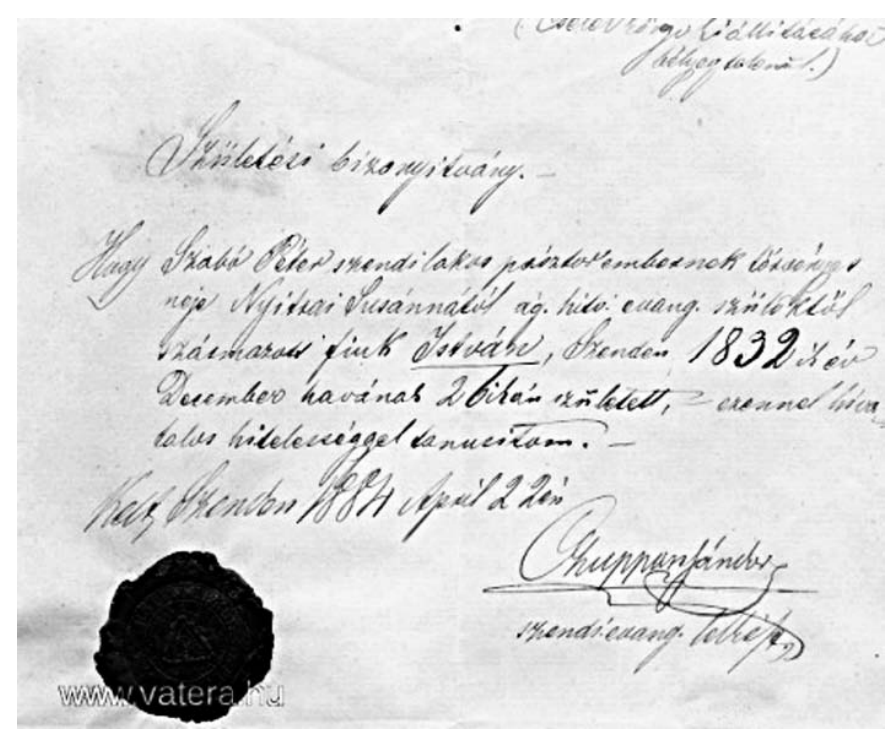

1. kép. Születési bizonyítvány 1884-böl (Forrás: wwww.vatera.hu)

A halotti levél megnevezés szintén nem új keletű. Az Erdélyi magyar szótörténeti tárban találunk adatokat a levél főnév 'hivatalos irat' jelentéseire (1. 'okirat', 2. 'kiváltságlevél', 3. 'adománylevél', 4. 'szabadságlevél', 5. 'birtoklevél', 6. 'záloglevél' stb.), de más források is jelzik, hogy megőrzött régiségről van szó. Ime, egy ilyen adat 1846-ból: Szülés után beavatástól 24 krajcár, temetéstöl 30 krajcár, esketéstól 1 forint jár. Keresztelésért a plébániabeliek 1 forintot, a külsők kétannyit, esketéstól 1 forintot, a külsők kétannyit, halotti levél kiadásáért 1 forintot, a külsók kétannyit fizetnek. ${ }^{53}$ De idézhetünk adatot korábbról is. Az 1790-es évekből származik Dukai Takács Terézia A mátka keserve című verse, amelyben is előfordul a halotti levél kifejezés: „Hol maradtak a címerek, / halotti levél,/ hol a fátyol, szövetnekek, / a selyem födél?"

Ugyanez lehet a helyzet a hajtási jogositvány megnevezéssel. A kifejezés elterjedtségét erdélyi, felvidéki és vajdasági adatok egyaránt jelzik a Termini-szótárban. Úgy tűnik, ebben az esetben is a peremrégiók nyelvváltozataiban őrződött meg a régebbi megnevezés. Ezt igazolja egy 1932-es, Budapesten kiállított dokumentum, amelynek a címe: Hajtási jogosítvány teherszállító kocsira (1. a 2. képet)

${ }^{53}$ Lichtneckert András: Csopak és Kövesd a polgári átalakulás útján (http://www.lichtneckertandras.hu/bibl_04_VI_07.htm) [2013] 


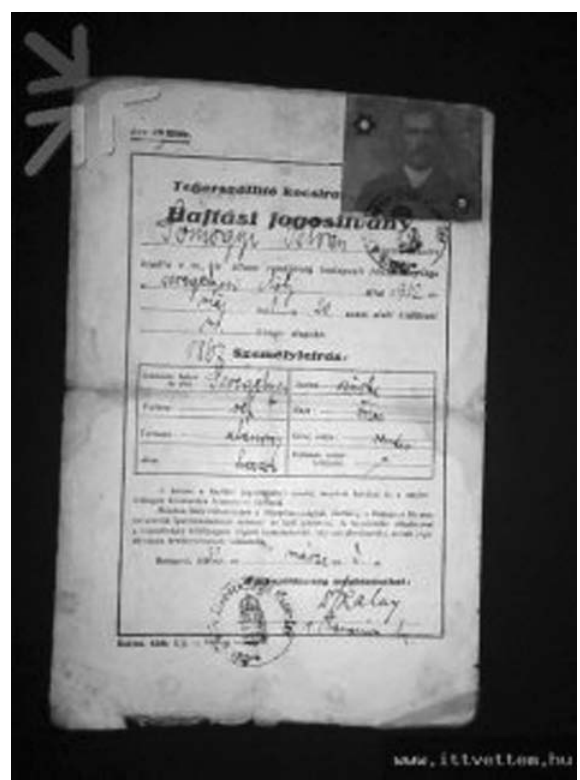

2. kép. Hajtási jogositvány 1932-ből (Forrás: www.aukcio.ittvettem.hu)

Megőrzött régiségnek tekinthető a szabálysértés jelentésű kihágás, amely a magyar jogi szaknyelvben használatos volt 1955-ig, és jelenleg általánosan elterjedt írott szövegekben is Erdélyben, Felvidéken, Kárpátalján és a Vajdaságban. A Magyarországon tiszthelyettesként használt terminus a kisebbségi nyelvváltozatokban jelenleg altiszt, és az elérhető adatok szerint valószínúleg az egész magyar nyelvterületen általánosan elterjedt volt még a 20. század első felében is.

Ezek a nyelvi régiségek nem elavultak, az internetes adatok szerint ma is használatosak Magyarországon az informális megnyilatkozásokban, de más a stílusértékük, nem hivatalosnak, nem szakszerünek, régiesnek vagy szokatlannak tünhetnek, míg a külső régiók nyelvváltozataiban stilisztikailag semlegesnek tekinthetők.

Úgy tünik, ezek az adatok igazolják Szilágyi N. Sándor azon véleményét, hogy nem pusztán arról van szó, hogy a kisebbségi magyar nyelvváltozatok módosultak a 20. század folyamán, hanem a magyarországi nyelvváltozat is különfejlődött a peremrégiók nyelvhasználatához képest (Szilágyi 2008: 108), és ez természetesen azt is jelenti, hogy a hivatali nyelvhasználat és ennek következtében a formális köznyelv tért el nagyobb mértékben a régebbi terminusok használatától, és ilyen módon a különbségek némelykor azt jelzik, hogy a peremrégiók beszélői régebbi, archaikusabb megnevezéseket őriztek meg. 



\section{HIBRIDSZERKEZETEK}

Mivel a hibridszerkezetekben a közvetlen átvétel (idegenszó-alkalmazás) és a tükörfordítás egyaránt jelentkezik, célszerű a hibrid kontaktusjelenségeket külön kontaktológiai kategóriaként kezelni. Ugyanakkor tanácsos a szószintű és a szószerkezetszintű hibridjelenségeket, a hibridszavakat és hibridszerkezeteket külön leírni, lévén hogy a két jelenség eltérő nyelvi szinteken érvényesül.

\section{Hibridszavak}

A hibridszavak olyan összetett szavak, amelyeknek egyik eleme idegen szó, a másik eleme pedig tükörfordítással hozzárendelt tag, amely egyaránt lehet alaptag vagy determináns (minősítő elem). Ezek, akárcsak a közvetett jelenségek nagy többsége, a nem standard nyelvváltozatokban jelentkeznek: az informális szaknyelvhasználatban és az ehhez a regiszterhez is kapcsolódó hivatali, közérdekű diskurzusokban.

A szaknyelvi megnyilatkozásokban megjelenő hibridszavakat példázzák az alábbiak:

gráddolgozat (id+isk) (szak) (biz) 'módszertani dolgozat az I. tanári fokozat megszerzésére (Romániában)': A gráddolgozatát a falusi oktatás kérdéseiröl írta (f.n.) (r. lucrare de grad 'ua.').

grádvizsga (id+isk) (szak) (biz) 'fokozati vizsga (pedagógusoknak, Romániában)': Azt, hogy a régiség vagy a grad vizsga "mittudomén milyen hülyeség" lenne, tanár szüleim nevében is határozottan kikérem magamnak! (www. itthon.transindex.ro) (r. examen de grad 'ua.')

licencvizsga 'egyetemi záróvizsga' (r. examen de licență 'ua.'). 
Nemcsak román mintára keletkezhet hibridszó, hanem egy, román hatást jelző, meghonosodott lexéma és egy magyar köznyelvi szó összevonásából is, amint a pótszesszió kölcsönelem ezt jelzi:

pótszesszió (ált) (szak+közél) (biz) 'pótvizsgaidőszak, utóvizsga-időszak': Az első olyan nagyobb változás mely életbe lépett, arra vonatkozik, hogy ne csak összel, hanem mindkét félévet záró vizsgaidőszak után legyen egy hét pótszesszió, amikor is a vizsgán elbukott hallgatók, újra megpróbálhatnak átmenó jegyet szerezni. (www.erdon.ro).

A szesszió szó 'vizsgaidőszak' értelemben jelentésbeli kölcsönszó (r. sesiune 'viszgaidőszak'). De a pót- előtag nem annyira fordításként, hanem inkább a pótvizsgaidôszak mintájára keletkezhetett. Ezt a feltélezést erősíti, hogy románul a 'pótvizsgaidőszak' sesiune de restanțe, amelynek szó szerinti jelentése: elmaradt vizsgák időszaka.

Az informális szaknyelv mellett a közéleti nyelvváltozatban is megfigyelhetők a hibridszavak. Ezek rendszerint intézményt, iratot, használati tárgyat vagy közlekedési eszköz jelölnek:

kasszabon (nép) (szak+közél) (biz) 'pénztári blokk': Feltétel volt még az említett lap versenyszelvényének kitöltése, valamint a hiteles kasszabonok csatolása. (www.ujkelet.ro) (r. bon de casa 'ua.')

motorinakályha (nép) (közh) (köz) 'olajkályha': Eladó háromégős gáztüzhely sárga bödönnel, mosógép, német motorinakályha. (www.nyugatijelen.com) (r. cuptor pe motorina 'ua.').

motorinajegy (ált) (közh) (köz) 'földművelőknek nyújtott állami gázolaj támogatást igazoló cédula, amelyre gázolajat lehetett vásárolni': Földtulajdonosok már kivették a polgármesteri hivataloknál az őszi vetésre és szántásra járó állami támogatásként kapott motorinajegyeket. (www.hhrf.org/hargitanepe) (r. bon de motorină 'ua.').

rapidvonat (fn) (nép) (közh) (köz) 'gyorsvonatfajta, amely még kevesebb helyen áll meg, mint a hagyományos gyorsvonat': Az új menetrendből tájékozódtam a csatlakozási lehetốségekról, kiválasztva a Gyergyószentmiklósról éjszaka 2 óra 14 perckor induló Bukarest-Nagybánya gyorsot, amelyhez reggel egy órán belül rapidvonat-csatlakozási lehetőség van Szatmárnémeti irányába. (www.hhrf.org/rmsz) (r. tren rapid 'ua.').

someriroda (id+nép) (szleng) 'munkaügyi hivatal (a munkanélküli segély ügyét is adminisztráló hivatal)': A Hargita Megyei Munkaerő Elhelyezó Ügynökség (Sommer iroda) ingyenes szakmai képzésben részesíti azon személyeket akik vidéken élnek és hivatalos munkaviszonnyal nem rendelkeznek. (www. disputa.ro) (r. biroul de somaj 'ua.'). 


\section{Hibridszerkezetek}

Amint szó volt róla, a hibridszerkezetek szintagmát alkotnak, és az ilyen adatok azt jelzik, hogy a szaknyelvhez kötődő nyelvi megnyilatkozásban vannak jelen nagyobb mértékben, többnyire a szaknyelv tekintetében romándomináns beszélőknél. Ezt szemléltetik a következő példamondatos lexikográfiai adatok:

ambuláns kezelés (isk) (szak) (köz) 'járóbeteg-ellátás': Szemészeti panaszait ambuláns kezeléssel, múkönnyel és corneotrofikus zselével kezelték, éjszakára kötést tett szemére. (www.orvtudert.ro) (r. tratament ambulatoriu 'ua.')

kalendarisztikus terv (isk) (szak) (köz) '(félévi) tanmenet': Az egyéni tervezes formái: kalendarisztikus terv, tematikus terv (a tanulási egység terve), óravázlat. (www.legestart.ro) (r. plan calendaristic 'ua.')

rekuperációs központ (ált) (közh) (köz) 'rehabilitációs kórház': A fogyatékkal élő felnőttekröl az igazgató elmondta: számos projekten dolgoznak, az egyik ilyen a Marospetresen megépitendő rekuperációs központ szellemi fogyatékosok számára. (archiv.nyugatijelen.com) (r. centru de recuperare 'ua.')

van (nincs) a sztokon (id) (szak) (biz) 'van (nincs) a készleten': Jó napot! sajnos az a gép már rég nincs a sztokon. hamarosan kapni fogunk árut (a hónap végén). (www.pcmadd.com) (r. [nu] este la stoc 'ua.'].

A hibridszerkezetek kialakulása kapcsolatban van a szószerkezetben jelentkező idegen szó alaki meghonosodásával. Mivel bizonyos szavak több alakváltozatban is integrálódhatnak, a hibridszerkezeteknek is két vagy több alakváltozatuk lehet. A különleges(en gondos) kezelést igénylőknek létesített osztály; intenzív osztály megnevezése az erdélyi szaknyelvi és közéleti nyelvváltozatban reanimációs osztály és reanimáló osztály egyaránt használatos a r. secția reanimare terminus hatásának eredményeként. A reanimációs szó létezik a magyar orvosi szaknyelvben (de maga a szószerkezet nem), és ezért az első szószerkezetben a „magyarítás" meghonosodott kölcsönelem alkalmazásával történt. A reanimáló melléknév esetében pedig képzővel hoztak létre a beszélők egy olyan származékszót, amely hangalakilag közel áll a román etimonhoz, és mégis valamennyire magyaros. (Megjegyzendő, hogy az eddigi adataink szerint a magyar orvosi szaknyelvben reanimál ige használatos 'feléleszt a klinikai halálból' értelemben, de reanimáló származékszó az idézett szintagma részeként nem szerepel.)

Nem szaknyelvinek, hanem inkább a romándomináns beszélők körében általánosnak mondható, köznapi tárgyakat, cselekvéseket jelölő hibridszerkezetek is szerepelnek a Termini-adatbázisban. Ilyenek a követke- 
zők igei és névszói szerkezetek: akcsidentet csinál 'balesetet okoz' (r. a face accident 'ua.'), angazsálja magát 'elkötelezetten csinál valamit' (r. a se angaja 'ua.') jegyet komposztál 'jegyet kezel (a buszon)' (r. a composta bilet 'ua.'), csentrálát tesz be 'kazánt szerel be' (r. a pune centrală), szanitár szesz 'egészségügyi szesz' (r. spirt sanitar).

Megfigyeléseink szerint egyértelműen a szubstandard nyelvváltozatokban és az alacsonyabb iskolázottságú romándomináns kétnyelvű beszélők használják az olyan hibridszerkezeteket, mint: csudája van 'haragszik, bosszankodik' (r. î e ciudă 'ua.'), falimentet ad 'csődbe megy' (r. a da faliment 'ua.'), széréléje van 'kft-t birtokol' (r. are srl. 'ua.'), tust csinál 'zuhanyozik' (r. a face duş 'ua.').

Összegezésként megállapíthatjuk, hogy a hibridszerkezetek kialakulása többféle nyelvváltozatban is megfigyelhető, de a külöböző regiszterekben az arányuk eltérő: a hivatali és a szaknyelvi használatban mutatnak nagyobb gyakoriságot, amint az idézett lexikográfiai adatok ezt jelzik. 


\section{A LEXIKAI ELEMEK MEGHONOSODÁSÁNAK ALAKTANI KÉRDÉSEI. A MÁSODLAGOS, HARMADLAGOS KÖLCSÖNELEMEK KIALAKULÁSA}

A lexikai kölcsönelem az átvevő nyelv (nyelvváltozatok) rendszerébe kerülve bonyolult alaktani, szemantikai viszonyhálózatok elemévé válik. Meghonosodásában meghatározó szerepet játszik az átvevő nyelv morfológiai rendszere, valamint azok a szóteremtő produktivitási szabályok, amelyeknek köszönhetően folyamatosan gazdagodik a nyelv ősi szavakból, jövevényszavakból és újabb keletü kölcsönelemekből létrejött képzős és összetett lexémákkal.

\section{Az átvevő nyelv morfológiai rendszerének hatása a kölcsönelemek meghonosodására}

Ismert, hogy a kölcsönelemek meghonosodásában az átvevő nyelv morfológiai struktúrája meghatározó szerepet játszik abban az értelemben, hogy megszabja az átvételek meghonosodási módjait a paradigmatikus rendszer különböző szintjein, és értelmezési keretként szolgál a grammatikalizáció folyamatában (Heine-Kuteva 2005: 79-120., Field 2002: 25-48., Thomason 2001b, Johanson 2008).

Az erdélyi magyar nyelvjárások román hatásának és a román nyelvváltozatok magyar eredetű kontaktusjelenségeinek vizsgálatakor figyeltünk fel arra, hogy a népetimológia és a belehallás jelensége nemcsak a fogalomjelölő szavaknál, azaz lexikai jelenségeknél mutatható ki, hanem a kötött morfémák szintjén is. Ez a folyamat megerősíti azt a felismerést, hogy a nyelvi kontaktusokban az átvevő nyelv morfológiai viszonyai meghatározzák a kölcsönelemek integrálódásának irányát (a román-magyar kontaktus szempontjából 1. Benő 2004: 51-58.; 2008: 91-103.). 
A jelenségkörnek számos pszicholingvisztikai vonatkozása van, és a kétnyelvű beszédmód rendszerjellegű interferenciáinak szabályszerűségeire is utal.

\subsection{Népetimológia és belehallás}

A népetimológiáról (szóértelmesítésről) főleg a lexikai átvételek meghonosodásával járó hangalaki adaptáció keretében szoktak beszélni. Mivel leginkább az idegen eredetű szavak esetében érvényesül, egyfajta adaptációs eljárásnak is tekinthető. Az alábbi román eredetü kölcsönelemek jelzik a népetimológia érvényesülését: r. comarnic 'féleresz a juhakolban, ahol a juhokat fejik' > m. nyj. komárnyék 'ua'; r. solniță 'sótartó' > m. nyj. sónica' ua'; r. huhurez 'bagoly' > m. nyj. huhurém 'ua.' (Márton-Péntek-Vöő 1977). ${ }^{54}$

A népetimológia a morfológiai jelenségek körében is tetten érhető, és rendszerint az értelmesítés következményének tekinthető szóelvonás jelzi ezt a motiváltságteremtő szándékot (l. a következő alfejezetet).

A belehallás jelensége rokon a népetimológiával, hiszen itt is az idegennek, ismeretlennek érzett hangalakot rokonítják valamely hasonló hangalakú anyanyelvi szóval. Csakhogy a népetimológia esetében ez mindig a lexéma hangsorának megváltozásával jár együtt, a belehallás esetén pedig a hangsor változatlan marad. Ugyanakkor abban is különbözik a belehallás jelensége a népetimológiától, hogy itt mindig jelentésváltozás áll be annak a hasonló alakú célnyelvi szónak a hatására, amelyet a beszélők fölfedezni vélnek a kölcsönelem hangtestében. Jól példázzák ezt a folyamatot a következő adatok: m. nyj. berszán 'vesszőből font szánforma gyermekjáték' < r. bîrsan 'barcasági'; m. nyj. szárika 'nadrág helyett viselt vászonból készült nadrágszár' < r. sarică' guba, szűr'; m. nyj. vakisa 'rövidlátó ember' < r. oacheşă 'fekete szemü, szemöldökű és hajú ember'; 'szeme körül fekete karikás juh' (Márton-Péntek-Vöő 1977). ${ }^{55}$

A kötött és a szabad morféma határának eltolódása szintén a belehallás jelenségéhez kapcsolható szemantikai folyamatot tükröz. A román eredetű gyakorító igéket vizsgálva figyeltem fel arra, hogy a -gál szóvéget gyako-

\footnotetext{
${ }^{54}$ A következő magyar és angol adatok szemléltetik a népetimológia más nyelvekben való megnyilvánulását: lexikai érvényesülését: $c$. hohano 'csaló, hazug' > m. hóhányó; t. qara qatna 'fekete madár' > m. kárókatona; fr. escrevisse 'rákhéj' > ang. crayfish 'rák'; lat. asparagus > ang. sparrow-grass 'spárga'; fr. dormeuse 'alvó, hibernáló' > ang. dormouse.

Az adatokat kísérô rövidítések feloldása: ang.: angol, ang.norm.: anglonormann, c.: cigány, fr.: francia, lat.: latin, $m .:$ magyar, $n .:$ német, $n y j .:$ nyelvjárás, ófr.: ófrancia, $r .:$ román, szl.: szláv, t.: török

${ }^{55} \mathrm{Az}$ angol hamburger szó produktivitása is utal erre a jelenségre: az angol nyelvü beszélők belehallották a szó hangalakjába a sonka jelentésü ham lexémát, és ennek a vélt összetételnek a mintájára új összetételeket alkottak (cheeseburger, fishburger, baconburger).
} 
rító képzőként fogták fel az olyan igéknél, amelyeknek román etimonjai -g tővégüek (vagy ilyenként értelmeződnek) és a magyarban -(á)l igeképzővel honosodtak meg. Ezt az ige jelentésének gyakorító mozzanattal való gazdagodása igazolja, amint azt némely kölcsönszó jelentésmódosulásában láthatjuk:

r. zbîng 'valamely eldobott tárgy ütközésekor keletkező hangot utánzó szó' > m. (meg)zbingál 'meghajigál'

r. jingás 'finom, gyönygéd, törékeny, válogatós, finnyás' $>\mathrm{m}$. zsingás 'kényes, válogatós' $\rightarrow z$ singál 'vizsgálgat (vevő az áru minőségét)'.

Nagyon természetes volna a román etimon alapján, hogy a zbingál ige 'meghajit' jelentésben legyen használatos, de a szóvégződésbe a magyar beszélők „,belehallották” a gyakorító jelentésre utaló -gál szuffixumot is, és ez kihatott a kölcsönszó jelentésének az értelmezésére.

A belehallás eredményének tekinthetjük azt a folyamatot is, amelynek során a románban magyar eredetü kölcsönszók szóvégi magánhangzóinak grammatikai nemet jelölő funkciót kezdtek tulajdonítani, amint ezt az alábbi átvételek jelentésmódosulásai jelzik:

m. ronda $>$ r. roandă 'alacsony, gyenge no" ${ }^{\prime 56}$

m. vizsla > r. vijlă'romlott nö'. ${ }^{57}$

Mivel a románban a szóvégi $-a,-\breve{~ m o r f e ́ m a ~ a ~ n o ̋ n e m u ̋ ~ f o ̋ n e v e k ~ j e l o ̈ l o ̋ j e, ~}$ ezekhez a magyar eredetü szavakhoz a románban nemcsak grammatikai nem társult (a nőnemű főnevek paradigmasorába illeszkedtek), hanem éppen ennek következményeként - új jelentésekkel gyarapodtak.

A belehallás jelensége olykor kihat a szó morféma értékére, sőt befolyásolhatja a szó alaki integrációját az átvevő nyelvben, amint azt az alábbi magyar eredetű román kölcsönszók román nyelvi meghonosodása jelzi:

m. bakancs $>$ r. bocanci (többes számú alak) $\rightarrow$ bocanc (egyes számú alak) m. döblec > r. dubleț (többes szám) $\rightarrow$ dublete (egyes szám)

m. prézli > r. prezli (többes számú alak) $\rightarrow$ prezlu (egyes számú alak). ${ }^{58}$

\footnotetext{
${ }^{56}$ Bulgăr-Constantinescu-Dobridor 2002, Tamás 1966.

${ }^{57}$ A magyar eredetű román kölcsönszók adatai Tamás Lajos történeti-etimológiai szótárából származnak (Tamás 1966).

${ }^{58}$ Kis 1975: 50-51
} 
A módosulások arra utalnak, hogy ezek a magyar eredetű jövevényszók a román népnyelvben többes számúnak értelmeződtek, a többes szám paradigmasorába illeszkedtek, és a román anyanyelvűek nyelvérzéke szabályos átalakítással megalkotta az átvételek egyes számú alakját.

\subsection{Szóelvonás és integrálódás}

Az átvételek morfológiai integrálódásában népetimológiával érintkező jelenségnek tekinthető az a folyamat, amelynek eredményeként elvonással megrövidül egy morfológiailag összetett szónak gondolt lexéma hangsora, és ez rendszerint azért megy végbe, mert tévedésből az idegen vagy meg nem honosodott fonémasor valamely elemének toldalék funkciót tulajdonítanak a beszélők. A magyar nyelv története több adattal is szemlélteti ezt a folyamatot:

n. marchat 'vagyon, áru, jószág' > m. marchát $\rightarrow$ marha

n. standart $>\mathrm{m}$. standárt $\rightarrow$ standár 'lovassági zászló'

szl. jagnjed $>\mathrm{m}$. jegyenyéd $\rightarrow \mathrm{m}$. jegenye.

Az első két adatsor arra utal, hogy a magyar hangalak úgy alakulhatott ki, hogy a szóvégi - $t$ mássalhangzónak a nyelvérzék tárgyrag funkciót tulajdonított, és elvonta. A jegenyéd esetében a $-d$-t valószínúleg az ómagyar korban kicsinyítő képzőnek, esetleg birtokos személyjelnek tekintették, és ilyenként vonták el.

A román-magyar kontaktusfolyamatokban a következő jelenségek utalnak erre a folyamatra:

a) A szóvégi - $k$-t és - $t$-t vélt többes számú jelként, illetve tárgyragként vonták el a következő esetekben:

m.nyj. goda (< godák) 'kocamalac' < r. godac 'egyéves malac'

m. nyj. kalabálé (< kalabálék, kalabalyik) (csángó nyelvjárási adat) 'veszekedés, csetepaté' < r. calabalîc 'ua.'

m. nyj. domika (< domikát) 'kenyérleves túróval' < r. domicat 'ua.'

m. nyj. roska (roskát) 'vörhenyes, piros színú (állat) < r. roșcat 'vörös(es)'.

b) Az -a szóvégződés némelykor birtokos személyragként értelmeződött, és emiatt elvonódott a következő adatokban:

m.nyj. bánic (< bánica) '15-20 literes véka' < r. baniţă 'ua.'

m. nyj. matász (< matásza) 'nyersselyem' < r. mătasă 'ua'. 
m. nyj. musztác (< musztáca) 'bajusz' < r. mustaţă 'ua.'59

Hasonlóképpen bizonyos szintaktikai kontextusban magyar helyhatározóragnak értelmeződhet a szóvégi - $b a$ és - $n$ :

r. cocioarbă $>$ m. nyj. kocsorba 'juh fülébe vágott jegy' $\rightarrow$ kocsor (az olyan mondattani környezetek kedveztek ennek a jelenségnek, mint a következő: "többnyire a kocsorukba szoktak jelet vágni")

r. nyj. gârcian > m. nyj. gircsán 'ádámcsutka' $\rightarrow$ gircsa.

\subsection{Morfémacsere}

A kölcsönelem meghonosodásakor olykor a toldaléknak vélt szóvégi fonémacsoport egy másik, a szó jelentéséhez közelebb álló szuffixummal helyettesítődik, azaz m orfém a csere történik. A magyar-román kontaktus köréből a következő adatok idézhetők erre a jelenségre:

m. fakalán > r. făcălan $\rightarrow$ făcălet

m. tolvaj > r. nyj. toluoi $\rightarrow$ tîlhar.

A făcălan magyar eredetü kölcsönelem -an végződése toldalékként értelmeződött a románban, és felcserélődött egy megfelelőbbnek talált kicsinyítő képzővel. Ugyanilyen módon a tolvaj román nyelvjárási hangalakjából (tuluoi) a román köznyelvben tîlhar lett, mivel a nagyító képzőnek értelmezett -oi egy megfelelőbb, ágensre utaló képzővel (-ar) cserélődött fel. ${ }^{60}$

A morfémacserét olykor a hasonló jelentésű és hasonló hangalakú szavak jelentésmezőbeli érintkezése is motiválhatja:

m. koldus > r. coldan $(\leftarrow$ sărman, goldan $)$.

Az -us szóvégnek a román beszélők kicsinyítő képző funkciót tulajdonítottak, mivel a románban van hasonló hangalakú kicsinyítő funkciójú képző (r. -uş), és így egy olyan képzővel cserélődött fel, amely a hasonló jelentésü szavak morfémaszerkezetében jelentkezik (sărman, golan).

Ugyanez ez a lexikai-morfológiai folyamat ment végbe a magyar törzs főnév erdélyi román népnyelvi adaptációjában:

\footnotetext{
${ }^{59}$ Ebben a fejezetben valamennyi román eredetű kölcsönszó forrása a Magyar nyelvjárások román kölcsönszavai című monográfia (Márton-Péntek-Vöő 1977)

${ }^{60}$ Kis 1975: 70.
} 
m. törzs > r. turj> r. turjan 'kukorica szár' $(\leftarrow$ cocean, strujan).

Valószínűleg itt is a hangalaki és szemantikai asszociációval van dolgunk, és a turj hangalakból minden bizonnyal a hasonló hangsorú és jelentésű cocean, strujan szavak hatására alakulhatott ki a turjan alak. ${ }^{61}$

Ezzel párhuzamos jelenségnek tekinthető az erdélyi magyar nyelvjárásokban román eredetű főnevek -uj végződéssel való meghonosodása. A szakirodalomban meglehetősen sokat írtak erről a jelenségről (Blédy 1942: 14, Zsemlyei 1969, Bakos 1970). A román hímnemű főnevek végartikulusából (-ul) eredeztetett szóvégződés számos román eredetű erdélyi tájszóban megjelenik (mutuj 'ostoba', prosztuj 'ügyetlen', kukuj 'daganat'), és az értelmezésünk szerint egyfajta honosító funkciója is kialakult. Ez abból látszik, hogy a románban - $a$-ra, -ă-re végződő, azaz nőnemű főnevek alaki integrációjában is megjelenik a korábban meghonosodott román eredetü jövevényszavak analógiájának hatására, tehát teljes mértékben az átvevő nyelvben zajló jelenségről van szó, mivel a románban ez a végartikulus nem járulhat nőnemü főnevekhez:
r. bică $>$ m. nyj. bikuj
r. cioarsă $>$ m. nyj. csorszuj
r. ciurcă $>$ m.ny. csurkuj.

A román eredetű szavakban gyakran megjelenő szóvégződés szuffixummá válását jelzi, hogy az olyan kölcsönelemek meghonosodásában is jelentkezik, amelyekben az etimon -oi nagyítő képzőre végződik:

r. acoi 'zsákvarrótü'> m. ny. ákuj 'ua.'

r. furcoi 'nagy villa' > m. ny. furkuj 'ua.'

Hasonló módon egy képző kialakulásának a folyamatát láthatjuk a románban az -ău kicsinyítő és pejoratív képző megjelenésének a történetében. Kiss Emese, Alexandru Nicolescu és mások is úgy vélik, hogy az ó-ra végződő magyar eredetű -ău szóvégü kölcsönelemek meghonosodása tette lehetôvé ezt a folyamatot az olyan lexikai integrálódás hatására, mint amelyet az alábbi adatok szemléltetnek:

m. bíró > r. birău

m. fogadó > r. făgădău

\footnotetext{
${ }^{61}$ Kis 1975: 160.
} 


\section{m. kotró > r. cotrău..$^{62}$}

A toldalék produktivitását és valódi képző státusát jelzi az, hogy a román népnyelvben nemcsak magyar eredetü szavakban jelentkezik, hanem belső keletkezésű regionális szintü lexikai elemekben is: jarcalău, jarpalău, budalău, rapalău, zdrăngălău, babalău, bujbalău, zdrobalău, dubalău, crancalău, şăncălău, păşcălău. ${ }^{63}$ Ez a folyamat ugyanakkor a nyelvi kontaktusok hatására megjelenő grammatikalizáció kérdéskörével is érintkezik.

\section{Másodlagos, harmadlagos kölcsönelemek kialakulása. Produktivitási szabályok}

Közismert, hogy a meghonosodás útjára lépő lexikai kölcsönelem az átvevő nyelv alaktani rendszerébe illeszkedve, átvevő nyelvi prefixumokkal és szuffixumokkal gazdagodhat. Sőt az alaktani meghonosodásuknak egyfajta jelzője az átvevő nyelvi képző vagy igekötő megjelenése a szó morfémaszerkezetében. Mivel az igei és a névszó alaktani rendszer jelentős mértékben különbözik, célszerü a kölcsönelemek körében is külön tárgyalni az igei és a névszói átvételek alaktani kérdéseit .

\subsection{Igei átvételek alaktani integrálódása}

A román igei átvételek nagy többsége (mintegy 60\%-a) -l igeképzővel honosodik meg a magyarban, akárcsak más nyelvekből származó igéink esetében (pl. dirigál < lat. dirigere; blokál < ném. blockieren; kapiskál < ol. capisco). Ez azt jelzi, hogy a magyarban az -l igeképző egyfajta honosító képzőként is számon tartandó. A legtöbb angol eredetü ige szintén ezzel a képzővel integrálódott: $d$ zsoggingol 'kocog' < ang. jogging; lincsel 'erőszakos önbíráskodást gyakorol' < ang. lynch 'lincsel'; lízingel 'kölcsönbérleti szerződést köt'< ang leasing; shoppingol 'vásárol (hipermarketben)' < ang. shopping 'vásárlás'; szervál 'adogat (labdát a teniszben)' < ang. serve 'felszolgál; adogat' (Zaicz 2006). A számítógépes nyelvhasználatban, a digilektusban használatos angol eredetű igék nagy többségének morfémaszerkezetében megfigyelhető ez a honosító képző: eszképel 'kilép (valamilyen számítógépes alkalmazásból)' (< ang. escape); lájkol 'tetszését fejezi ki' (< ang. like);

\footnotetext{
${ }^{62}$ Kis 1975: 76, Niculescu 2005: 31. Az -ău képzővé válásának a magyar eredetű román településnevekben való megjelenése is kedvezett (pl. Bakó > Bacău) (Niculescu i.m.). Ugyanakkor azt is figyelembe kell vennünk, hogy a románban nemcsak a -ó végződésű magyar eredetü szavak honosodtak meg -ău szóvégződéssel, hanem más fonémaszerkezetű kölcsönelemek is: m. Kisjenő > r. Chișinău, m. Zilah > r. Zalău, m. Gyalu > r. Gilău.

${ }^{63}$ Zafiu 2007.
} 
lódol 'feltölt (számítógépes állományt)' (< ang. load); szével 'elment (számítógépes állományt)' (< ang. save); sérel 'megoszt (interneten keresztül valamilyen anyagot)' (< ang. share). Sőt, névszói eredetü angol kölcsönelemek is igévé válhatnak a magyar $-l$ vagy $-z(i k)$ igeképző használatával: imélezik < ang. e-mail 'elektronikus levél'; féjszezik 'használja a Facebook nevű közösségi oldalt' < ang. Face(book) 'népszerủ közösségi oldal neve'; guglizik 'Google internetes keresőprogramot alkalmaz' < ang. Google 'a keresőprogram neve'; szkájpol 'a Skype nevü internetes programot használja távbeszélgetésre'< ang. Skype. Amint az utóbbi adatokból látható, tulajdonnevekből is keletkezhetnek képzett igék ugyanolyan módon, mint a köznevekből.

Az erdélyi magyar népnyelvi, román eredetű kölcsönelemek körében a következő adatok jelzik az -(á)l képző nagymértékű produktivitását:

r. a doini 'dojnát énekelni' > Er. m. nyj. dajnál 'részegen, rosszul énekel'

r. a detașa > Er. m. detasál 'ideiglenesen áthelyez'

r. a incadra $>$ Er. m. inkadrál 'besorol a munkahelyre'

r. a clefeti, cleveti 'gyorsan, tagolatlanul beszél' > Er. m. nyj. klefetyál 'sokat beszél'

r. a mesteca > Er. m. nyj. mesztekál' összekever, elegyít valamit'

r. a sfinți 'szentel' > Er. m. nyj. szfincál 'házat szentel'

r. a urgenta 'megsürget' > Er. m. nyj. urdzsentál 'telefonkapcsolást sürget'.

Ez nem azt jelenti azonban, hogy minden igei átvétel ugyanazzal a képzővel illeszkedik az átvevő nyelv ragozási sorába. Ha az átvevő nyelvnek gazdag igeképző- rendszere van, mint például a magyar nyelvnek, akkor az igei átvételek az igei jelentés és a képző funkciója függvényében társulnak a meghonosodás folyamatában levő igei átvételhez. Ha a kölcsönzött ige jelentése valamivel való ellátást fejez ki, akkor a -z igeképző lesz alkalmas arra, hogy az idegen elemet morfológiai értelemben is elfogadhatóvá tegye, amint azt a következő, az erdélyi magyar nyelvjárásban használt román eredetű igék szemléltetik:

r. a marca 'megjegyezni' > m. nyj. márkáz 'megjegyez (fát)'

r. a mărgini 'szegélyez' > m. nyj. mardzsináz 'földutak szélét fával szegélyezi'.

Ha az igei átvétel jelentése a cselekvés gyakoriságára, ismétlődő jellegére utal, akkor az ilyen funkcióban használt átvevő nyelvi igeképzők (-[d] $z i k,-g$ ) lesznek alkalmasak az igei kölcsönelemek meghonosítására: 
r. a flutura 'száll, szállong, libeg' > m. nyj. fluturáddzik 'nagy pelyhekben hull a hó' rült víz'

r. a vijii 'zúg, csorog' > m. nyj. vizseg 'szortyog, cuppog a csizmába ke-

r. bîz 'züm-züm' > m. nyj. bizzeg 1. 'pezseg, forr'; 2. 'zümmög'.

Az igei kölcsönszó meghonosodását erősíti, ha a honosító képzővel együtt a szó jelentése is módosul annak köszönhetően, hogy más igeképző jelentését is belehallják a kölcsönelem hangszerkezetébe. A magyarban például az -ál igeképző a cselekvés folyamatosságára, ismétlődésére, elaprózottságára is utalhat (pl. dobál, himbál, kalimpál, lobál, ugrál). A viszonylag nagy számú, a románban - $i$ vagy - $a$ végződésű ige az erdélyi magyar nyelvjárásokban az -(á)l honosító képzőnek köszönhetően -ál végződéssel integrálódott. Ezek közül némelyek a cselekvés folyamatosságára, ismétlődésére utaló szemantikai jeggyel gazdagodtak. A folyamat legvilágosabban az etimonokhoz viszonyított jelentéseltolódásokból látszik:

r. ciocni 'összeütődni zajt csapva, húsvéti pirostojást összekoccantani, koccintani' > m. csoknyál 'összeüt, pirostojást ütöget'

r. măsura 'mérni' > m. maszurál 'mér, méreget'

r. porni 'elindulni, elindítani' > m. pornyál 'legelészget a juhnyáj'

r. zbîngăi 'megcsendül' > m. zbingejál 'megsodort zsinórra füzött gombot húzogat'.

Itt a folyamatosságot, ismétlődést jelölő magyar -ál igeképző jelentésbesugárzása valószínü, ami egyben a jelentésspecializálódás révén a kölcsönelemek meghonosodását funkcionálisan indokolttá tette.

Ha az -(á)l igeképző olyan hangalakhoz társul, amely morfológiailag összetett, és tartalmaz átadó nyelvi képzőt, összetett képzők kialakulásnak lehetünk tanúi. Ilyen a más nyelvekből származó idegen szavakban is előforduló -izál képző, amely nyilvánvalóan egyfajta összeolvadás eredménye:

r. a deratiza $>$ Er. m. deratizál 'rágcsálót irt'

r. a ecologiza > Er. m. ökologizál' védi a környezetet, csökkenti a környezetszennyezést'

r. a coloniza > Er. m. kolonizál 'többségi etnikumú lakosságot telepít'

r. a penaliza $>$ Er. m. penalizál 'pénzlevonással büntet'

r. a repartiza > Er. m. repartizál 'vkit vhova beoszt, kinevez'

r. a sponzoriza > Er. m szponzorizál 'szponzorál, anyagilag támogat' 
A kontaktusjelenségek eredményeként kialakult -izál képző bizonyos mértékü önállóságát és produktivitását jelzi, hogy tréfás szóalkotás eredményeként ősi magyar szóhoz is kapcsolódhat, amint ezt a pejoratív jelentésű urizál igénk jelzi.

Az ig e kötő, akárcsak a képző, a lexikai átvételek integrálódását segíti elő, és rendszerint a másodlagos képzős alakokból harmadlagos kölcsönelemek kialakulását teszi lehetővé. Az igekötő nemcsak enyhíti az idegen szó idegenségét, etimológiai motiválatlanságát, hangalaki szokatlanságát, hanem grammatikai és jelentésbeli viszonyrendszerbe állítja az igei átvételt.

Általában az igei átvételhez járuló igekötő motiváltsága abban rejlik, hogy a kölcsönszó érintkezésbe lép az átvevő nyelvbeli szinonimapárjával, és mintegy örökli annak igekötős szabályrendszerét. Az alábbi adatok ezt a jelenséget példázzák:

r. făcătură 'igézés' > m.nyj. faketurál - megfaketurál $(\leftarrow$ megigéz $)$

r. a scăpa 'megmenekül' > m.nyj. szkëpál - megszkëpál 'megmenekül' $(\leftarrow$ megszabadul)

a spovedi 'gyón' > m.nyj. szpovegyál - megszpovegyál 'meggyón' ( $\leftarrow$ meggyón).

Vannak olyan esetek is, amikor egyértelműen és jogosan magyarázható valamely konkrét magyar igekötős szerkezet hatásával egy-egy igekötős, román eredetű kölcsönelem. Ilyenek azok az adatok, amelyeknek a magyar jelentésbeli ekvivalense igekötős, azaz igekötőjének jelentésspecializáló szerepe van, és nem egyszerủen a cselekvés irányát vagy befejezettségét jelöli. Ilyenkor az adott magyar ige csak a jelentésspecializáló igekötővel együtt használható a szóban forgó jelentésben: mond)

r. nyj.floscoti 'mond, beszél' > m.nyj. floszketyál - odafloszketyál $(\leftarrow$ odarodik).

r. zăpăci 'megzavarodik' > m.nyj. zepecsál - megzepecsál $\quad(\leftarrow$ megzava-

Olyan igekötős összetételek is előfordulnak azonban, amelyekben nyilvánvalóan az igekötő nem egy konkrét magyar nyelvi szinonima hatásának eredményeként jelenik meg: leszuperálódik 'megharagszik', elszpurkál 'bepiszkít, összepiszkít', lemutujoz 'mutujnak, gyámoltalannak nevez', elmaritál 'férjhez megy'. Ezekben az esetekben sem lehet véletlenszerü az igekötők használata. Ha a jelenségre magyarázatot akarunk találni, akkor nem egy konkrét szinonimában kell keresnünk az adott igekötő használa- 
tának indítékát, hanem a szinonimasor vagy még inkább a jelentésmezők, az állandósult metaforikus névátvitelek szintjén.

Ismert, hogy az igekötő legkorábbi funkciója a cselekvés irányának megjelölése volt. Ebből származik mind a grammatikai funkció (aspektusképzés), mind a jelentés specializáló szerep. ${ }^{64}$ Ilyen értelemben mindkét funkció származéka azoknak a térbeli viszonyoknak, amelyeket az igekötőrendszer jelölni képes ${ }^{65} \mathrm{~A}$ mozgáshoz, a térhez kapcsolódó érzékelési élményeink elsődleges forrásai nemcsak fogalmi struktúráinknak, de a nyelv szemantikai rendszerének is. ${ }^{66}$ Az ilyen jellegű nyelvi anyag vizsgálata alapján megállapítható, hogy különböző térdimenziókhoz különböző metaforikus jelentésmezők kapcsolódhatnak. Szilágyi N. Sándor az értékjelentés szempontjából vizsgálta a nyelvi térviszonyok és a metaforikus értékek összefüggését: így a FENT és a LENT helyviszonyhoz, valamint az ehhez kapcsolódó F EL/LE irányhoz rendszerint pozitív, illetve negatív értékjelentés társul, amint azt a következő példák is szemléltetik: felszabadít, felmagasztal, feldicsér, fennkölt, felsóbbrendú, felnéz (vkire) - leigáz, lehord, leszid, lenéz (valakit). Ugyanilyen módon kapcsolódik a FENT és LENT dimenzióhoz az aktív/passzív értékjelentés: felbiztat, felbosszankodik, felbőszül, felbujt, felbuzdul, felcsigáz (érdeklődést), feldühödik stb - lecsendesit, lepisszeg, lecsillapit, lehiggad (Szilágyi N. 1996: 11-37; vö. Lakoff 1980). A térdimenzióknak és a metaforikus jelentéseknek ez a kapcsolata része lehet a beszélő implicit nyelvi tudásának, amennyiben ezt a szemantikai szabályszerüséget kreatív módon alkalmazni tudja új nyelvi elemek vonatkozásában is. Így válik érthetővé, hogy a mutuj melléknévből képzett mutujoz ige miért éppen a le igekötővel alkot összetételt. Az elmaritál igekötős szerkezet kialakulását könnyen értelmezhetjük a térdimenziók és a metaforikus jelentések kapcsolatában, hiszen ez a kapcsolat azt is jelenti, hogy bizonyos térbeli viszonyokra utaló vagy ezekből származó igekötős igék elsődleges vagy metaforikus jelentésszerkezetében van valami közös elem (elmegy, elköltözik, eltávozik [irány], elront, elhibáz, elmulaszt, elszomorodik, elidegenedik, elhidegül stb. [értékjelentés]). Ez a közös szemantikai tartalom megnyilvánul a speciális jelentésárnyalatbeli gazdagodásban (nevet - kinevet [vö. kicsúfol, kigúnyol], a hasonló névátviteles jelentésváltozásban (dól - eldool 'elválik valami', dönt-eldönt 'határoz valamiben'), valamint az értékjelentés azonosságában (az el igekötős összetételek általában negatív értékjelentésűek). Az elszpurkál igekötős szerkezet szemantikai motivációja ebben a megközelítésben érthető és világos, amennyiben az $e l$ igekötő egyik funkciója éppen érték-

\footnotetext{
${ }^{64}$ Az igekötő funkcióival kapcsolatban 1. D. MÁTAI 1992.

${ }^{65}$ Ezért sem választható mereven el az igekötőnek ez a két szemantikai vonatkozása, lévén hogy az igei aspektus kérdése is végső soron jelentésbeli probléma.

${ }^{66}$ LAKOFF 1980; DANESI 1990.
} 
vesztés jelölése. A leszuperálódik összetétel pedig a le igekötőhöz társítható passzív értékjelentés felől értelmezhető (Benő 2004b).

Mindez arra enged következtetni, hogy a meghonosodás útjára lépett kölcsönelem úgy integrálódik a nyelv rendszerébe, hogy nem csupán az átvevő nyelvbeli szinonimájával lép érintkezésbe, hanem azokhoz a viszonyokhoz is alkalmazkodik, amelyek az adott jelentésmezőt jellemzik. Az igekötős összetételek esetében nem csupán arról van szó, hogy az igei átvételhez a magyar szinonim ige megfelelö igekötője társul, hanem hogy a megfelelő jelentésrendszer mint metaforikus viszonyhálózat egésze hat rá.

Amint az adatokból kivehető, az igekötős igék rendszerint alakilag háromeleműek: igekötő+ szótő + képző szerkezetből állnak, tehát képzős alakú másodlagos kölcsönszavakból lett belőlük harmadlagos kölcsönelem.

\subsection{Névszói átvételek alaktani integrálódása}

A névszói elemek vizsgálata a kölcsönelemek szintjén gyakorlatilag a fônevek és a melléknevek morfológiai sajátosságainak a vizsgálatát jelenti, mivel névszói vagy névmási lexikai elemeket nem találunk a román eredetü kölcsönszók vizsgált adattáraiban.

\subsubsection{Főnevek integrálódása}

A főnevi kölcsönelemek hangalaki integrálódását és egyfajta használati elterjedtségét jelzi, hogy az idegen szóból képzéssel vagy szóösszetétellel újabb szavak keletkeznek. Ezt az összefüggést jól példázzák azok a régebbi, mára általánosan elterjedt román eredetű átvételek, amelyek többféle szófaji és alaki funkcióban használatosak. A kaláka és a cimbora szócsaládja jó példa erre: kalákás, kalákázik, kalákázás, elkalákázás; kalákagazdakör, kalákamunka, kalákatánc, aratókaláka, fonókaláka; cimbora: cimborál, cimborálás, cimborás, cimboraság, cimborázó, cimboráló, cimborabíró, cimboragazda, gyermekcimbora, lánycimbora, menyecskecimbora, katonacimbora, legénycimbora (Márton-Péntek-Vöö 1977). Hasonló módon a 'gyáva, ügyetlen' jelentésű mutuj (<r. mut 'néma)' melléknévből igei és főnévi alak is létrejött: $m u t u j k o-$ dik 'ügyetlenkedik', lemutujoz 'mutujnak nevez', mutujság 'ügyetlenség'.

$\mathrm{Az}$ alakilag összetett átvételek meghonosodásában megfigyelhető a szóvégi kötött morféma módosulása a hangalaki integrálódás folyamatában. Ebben a morfémacserében, illetve adaptációban megfigyelhetők, hogy a legközelebbi, természetesebb átvevő nyelvi képzőre cserélődik az idegenes hangzású képző a már meghonosodott idegen szók mintájára: 
- ist $\rightarrow$-ista:

r. metodist 'módszertanos' > Er. m. metodista 'ua.'

r. colectivist 'téeszes' > Er. m. kollektivista 'ua.'

r. culturist 'testépítö' > Er. m. kulturista 'ua.'.

-tie $\rightarrow$-ció:

r. cotizație 'tagdij' > Er. m. kotizáció 'ua.'

r. recreație 'pihenés, kikapcsolódás' > Er. m. rekreáció 'ua.'

r. circulație 'közlekedés' > Er. m. csirkuláció 'ua.'

r. intersecție 'útkereszteződés' > Er. m. interszekció 'ua.'.

Olykor nem annyira a hangalaki hasonlóság játszik szerepet a képzőcserében, hanem inkább az átadó nyelvi és az átvevő nyelvi képző funkcióbeli azonossága:

r. democratizare 'demokratizálás' > Er. m. demokratizáció 'ua.'

r. deratizare 'rágcsálóirtás' > Er. m. deratizáció 'ua.'

r. îndemnizare 'pótlék' > Er. m. indemnizáció 'ua.'

r. lichidare 'felmondás' > Er. m. likidálás 'ua.'

r. absolvare 'tanulmányok befejezése' > Er. m. abszolválás 'ua.'

r. deblocare 'deblokálás' > Er. m. deblokálás 'ua.'

r. ecologizare 'természet- és környezetvédelem' > Er. m. ökologizálás 'ua.' .

Amint a fenti adatok is jelzik, az -ás/-és képző előfordulása nem ritka, a -ság/-ség képzővel integrálódott főnevekre azonban csak néhány adatunk van: mutujság 'ügyetlenség, butaság', szekusság 'a kommunizmusbeli román politikai rendőrséghez való tartozás', somerség 'munkanélküliség'. Ezek többnyire valamilyen nyelvváltozatban meghonosodott másodlagos kölcsönszók. Vagyis azt mondhatjuk, hogy a -ság/-ség képző idegen szó státusú átvételekben nem jelentkezik.

Az idegen szók sajátos képzői olyankor is megjelenhetnek a kölcsönelemek hangalakjában, amikor ennek nincs megfelelője az etimon alakjában. Ilyenkor a képző honosító funkciója érvényesül: r. legionar'Romániai Legionárius Mozgalom nevet viselő szélsőjobboldali, fasiszta irányzatú politikai alakulat (1927-1941)’ > Er. m. legionárius. Hasonlóképpen integratív funkciójú morfématöbblet jelentkezik némely (végső soron latin eredetű) -us képzővel meghonosodott szó alakjában: kulturizmus 'testépítés' (<r. culturism 'ua'), anarchizmus 'anarchia' (r. anarhie, gr. anarchia), fabulózus 'mesés, csodálatos, meseszerü' (<r. fabulos 'ua.'). 
Amint fennebb a képzőcsere jelenségénél szó volt róla, ha több kölcsönelem ugyanazzal a szóvégződéssel honosodik meg, akkor az adott fonémák képző funkcióval gyarapodhatnak. Ezt leginkább az -uj végződésü román eredetű szavaknál láttuk (1.3. alfejezet).

A románban alakilag összetett lexémák grammatikai jelentése a meghonosodás folyamatában elhalványulhat. Ez történt például a többes számú alakban meghonosodott kölcsönelemekkel, amelyek a magyarban elveszítették többes számú funkciójukat: bani 'a lej századrésze' (< r. tbsz. bani 'ua') ,ári '100 m²-nyi terület' (<r. tbsz. ari 'ua').

A főnevek morfémaszerkezetében megjelenő elöljárók (prepozíciók) nem az alaki integrálódás jelölői, mint a magyar nyelvi képzők, mivel ezek legtöbbször az átadó nyelvből származnak, az idegen szó hangalakjával együtt kerülnek át az átvevő nyelvbe. Ezt a jelenséget példázzák a következő adatok: anticipatív 'megelőlegezett, megelőző, elébe vágó' (< r. anticipativ 'ua'); ántidzsel 'fagyásgátló' (< r. antigel 'ua.'); antinevráldzsik 'fájdalomcsillapító' (< r. antineoralgic 'ua.'); antitalent 'valamely területen teljesen tehetségtelen, hozzá nem értő ember' (< r. antitalent 'ua.'). Megjegyzendő, hogy sem a magyar standardban, sem az erdélyi regionális köznyelvben az anti- prefixum jelenleg nem mondható teljes mértékben meghonosodottnak, hiszen nem produktív, és csak kevés számú szóban, főleg terminusban jelentkezik (pl. antiinflációs, antibakteriális), és a nyelvérzék számára némileg idegenszerü. Kevésbé idegenszerünek tűnik, de bizonyos szavakkal nem használatos a köznyelvben a latin eredetú proelöljáró 'helyettes' értelemben, miközben az erdélyi magyar regionális köznyelvben a román hatás eredményeként természetesként hat a prorektor 'rektorhelyettes', prodékán 'dékánhelyettes' szavakban.

Szóösszetétel eredményeként új lexémák rendszerint meghonosodott átvételekből, jövevényszavakból keletkeznek. Szinte biztosra vehető, hogy az összetett szavakban jelentkező kölcsönelemek jövevényszavaknak tekinthetők valamilyen regiszter szintjén, amint az alábbi lexikai egységek ezt szemléltetik: aragázkályha 'propánbutángáz-tüzhely', aragázbutélia 'propánbutángáz-palack'; bálmospuliszka 'fehérsavóban főzött puliszka'; bálmosmálé 'édesmálé'; blokkház, blokklakás 'tömbház'; blokknegyed '(panelházas) lakótelep'; csobánbot 'juhászbot'; csobánkutya 'juhászkutya; esztrungahajtó 'a juhokat a fejéshez terelö bojtár'; 'motorinajegy' földművelőknek nyújtott állami gázolaj támogatást igazoló cédula, amelyre gázolajat lehetett vásárolni'; motorinakályha 'olajkályha'; pionírszervezet 'úttörő szervezet'; pionírruha, pionírtábor. 


\subsubsection{Melléknevek integrálódása}

A melléknévi kölcsönelemek leggyakoribb képzője az -s denominális képző. Ez a képző jelentős szerepet játszik az idegen szók hangalaki integrálódásában. Román eredetű kölcsönszavakhoz társulva az -s melléknévképző a következő grammatikai-szemantikai értékeket fejez ki:

1. 'valamivel való ellátottság, valamit tartalmazó':abonamentes 'bérletes' (< r. abonament 'bérlet'); balkonos 'erkélyes (lakás)' (< r. balcon 'erkély'); brinzás 'brinzát tartalmazó'(< r. brânză 'túrós, sajt'); maszkás 'álarcos' (< r. mască 'álarc)'; maszlinás 'olajbogyós' (<r. măslină 'olajbogyó')

2. 'valamilyen tulajdonságot hordozó vagy valamilyen álla potban levő' : fudzsitus 'hirtelenkedő, szeleburdi' (<r. fugit 'elfutott'); zsigorás 'görcsös betegségben szenvedö' (állat) (<r. jiğ̆raie 'köszvény'); szklerózás 'szklerózisban szenvedö' (< r. scleroză 'szklerózis')

3. 'foglalkozás, ideiglenes tevékenység': bufetos 'büfé tulajdonosa, bérlője vagy alkalmazottja' (< r. bufet 'büfé, kocsma'); cimborás 'szántáskor együtt dolgozó társ, pajtás' (< r. sâmbră munkára való összefogás'); kasszás 'pénztáros' (< r. casă 'pénztár'); kalákás 'közös munkában részt vevő egyén' (r. clacă 'közösben végzett munka'); líceumos 'gimnazista' (< r. liceu 'középiskola'); mechanikus 'autószerelö' (< r. mecanik 'ua'); navétás 'ingázó' (< r. navetă 'ingázás'); szekus 'romániai politikai rendőrség alkalmazottja (a kommunizmusban)' (<r., Securitate, Secu 'politikai rendőrség').

4. 'valamilyen (elvont) fogalomhoz kapcsolódó': kalákás 'kalákához füződő'; kolonizációs 'kolonizálással kapcsolatos' (< r. colonizare 'kolonizálás'); konverzációs 'idegen nyelvü társalgással mint tantárggyal kapcsolatos' (< r. conversație 'társalgás'); liceális 'középiskolai' (<r. liceal 'ua.'); lusztrációs 'lusztrációval, átvilágítással kapcsolatos (< r. lustrație 'lusztráció'); rekuperációs 'orvosi rehabilitációs' (< r. recuparare 'rehabilitáció'); restitúciós 'a restitúcióval kapcsolatos' (r. restituție, lat. restitutio 'visszaszolgáltatás'); vátrás 'a Vatra nevü nacionalista-soviniszta „kulturális” szervezet tagja, vagy az ezzel az intézménnyel szimpatizáló személy' (r. Vatra 'kulturális szervezet neve').

Az -s melléknévképző a lexikai integrálódás folyamatát többféle módon is támogatja. Egyrészt kép ző c serének tekinthető hangalaki módosulással teszi magyarosabbá az idegenszerü hangalakot, sokszor analóg képzők helyettesítésével: ákációs 'kötekedő' (< r. agățăcios 'ua.'), ambíciós 'ambiciózus' (<r. ambițios 'ua.'), performáns 'nagy teljesítményü' (<r. perfor- 
mant 'ua'). Másrészt egyfajta képzőhalmozás eredményeként a román származékszót elfogadhatóbbá alakítja a magyar vagy kétnyelvű nyelvérzék számára: brigadéros 'munkabrigád vezetője' (< r. brigader 'ua'), legendáris 'legendás' (< r. legendar 'ua') notorikus 'megrögzött; javíthatatlan' (< r. notoric 'ua').

Összegezésként elmondható, hogy az alaktani jelenségek arra engednek következtetni, hogy az elterjedő idegen szó úgy honosodik meg az átvevő nyelvben, hogy a morfológiai rendszer hatására alkalmazkodik azokhoz a szóteremtő eljárásokhoz és szabályokhoz, amelyek évszázadok óta gazdagítják a nyelv szókincsét szóképzéssel, szóösszetétellel és más ritkább szóalkotási módozatokkal. 


\section{JELENTÉSVÁLTOZÁSI TENDENCIÁK}

2000-ben megvédett doktori értekezésemben a román eredetű kölcsönelemek szemantikai jelenségeit elemeztem a 20. századi és annál korábbi nyelvi adatok alapján (Benő 2004a). Ebben a fejezetben az újabb adatok és kutatások fényében mutatom be az erdélyi kölcsönelemek jelentéstani kérdéseit, nem térve ki csak az említés szintén azokra a jelenségekre, amelyeket részletesen bemutattam a 2004-es kötetemben.

A közmagyar és a határon túli magyar nyelvváltozatokban megjelenő idegen és kölcsönszók jelentésbeli különbségeit a jelentéstan és a logikai viszonyok ismert kategóriái szerint kísérlem meg osztályozni. Mindvégig azonban szem előtt tartandó, hogy a jelentésviszonyok csak konstruáltak abban az értelemben, hogy leginkább nem a közmagyar jelentések eltolódásáról van szó, hanem rendszerint a többségi, az államnyelvből származó szemantikai interferenciáról, illetve az átvételek magyar nyelvi jelentésrendszerhez való alkalmazkodás következtében megjelenő belső különfejlődéséről (Benő 2004a, 2007b). Másrészt a magyarországi köznyelvre vonatkozó források nem mindig tükrözik hitelesen az élő nyelvhasználatot. Gondolok itt az idegen szavak szótáraira, amelyek többnyire megbízhatóak, de újabb jelentésvonatkozások hiányozhatnak is belőlük. Mivel jobb egybevetési lehetőségem nem igen adott, az egyik leggazdagabb és legújabb idegen szavak szótárát, a Tolcsvai Nagy Gábor szerkesztette lexikográfiai munkát (Tolcsvai 2007) használtam az összehasonlítás alapjául, lévén, hogy ez a szótár nagy mennyiségü nyelvi anyagot tartalmazó elektronikus korpuszokra (MNSZ, Magyar Történeti Korpusz) alapozva készültek a szócikkek. 


\section{A jelentésmódosulás forrása}

Az erdélyi köznyelvben megjelenő, köznyelvi szavakhoz társuló új jelentések a többségi nyelv szemantikai rendszeréből, illetve az erdélyi regionális köznyelvi változatból származnak.

Az erdélyi nyelvváltozatban és a közmagyarban egyaránt használatos szó jelentésbeli különbsége a legtöbbször román nyelv hatásával indokolható. Ez a szemantikai hatás új szemantikai tartalommal gazdagíthatja a szó jelentésszerkezetét. Így például a diploma 'iskolai bizonyítvány' jelentéssel gyarapodott, a bába bizalmas stílusértékben 'öregasszony' jelentésben is elterjedt a román diplomă és babă hasonló hangalakú szavak jelentésbesugárzásának köszönhetően. A románban ugyanis a diplomă szó alapjelentése 'szakmai felkészültséget igazoló okirat', a babă lexémának pedig 'idős asszony' a legelterjedtebb jelentése (DEX 1998).

A fentebb idézett adatok is jelzik, de számos más adat is tanúsítja, hogy rendszerint az átadó nyelvi hasonló hangalakú szó leggyakoribb jelentése, vagyis az alapjelentése kerül kölcsönzésre és meghonosodásra. Így lett román hatás eredményeként a blokk 'lakótelepi panelház, tömbház' jelentésü, a gimnázium pedig 'az általános iskola felső tagozata (V-VIII. osztály)' értelmü (a r. bloc 'tömbház', illetve a r. gimnaziu 'általános iskola, V-VIII. osztály' hatására) ${ }^{67}$

Egy adott lexikai elem alapjelentésében megegyezhet a többségi nyelvi hasonló hangalakú szó alapjelentésével, és ilyenkor a szemantikai különbség valamelyik származékjelentésből származhat. Így például a peron a magyar köznyelvben 'vasúti vágányok mellett kiépített útszerü sáv' jelentésű (Bakos 1989.), az erdélyi nyelvváltozatban 'kocsiállás (autóbuszpályaudvaron)' denotatív értékben is elterjedt, akárcsak a vajdasági és a horvátországi magyar nyelvváltozatban.

Némely szó több jelentéssel is gyarapodik a szemantikai hatás következményeként, azaz több átadó nyelvi származékjelentés hatása kimutatható. Jól szemlélteti ezt a jelenséget a katedra szó erdélyi jelentésbővülése. Az erdélyi magyar köznyelvben ugyanis 'egyetemi, föiskolai tanszék', illetve 'tanári állás' értelemben is használatos. ${ }^{68}$

Nemcsak a többségi nyelvből származhatnak a magyar köznyelvben kevésbé ismert jelentések, hanem a helyi regionális nyelvváltozatokból is. Népnyelvi hatás eredményeként az erdélyi magyar köznyelvben a tészta 'sütemény' jelentésű, a kap ige pedig 'talál, meglel valakit, valamit' érte-

\footnotetext{
${ }^{67}$ A felvidéki és a vajdasági magyar nyelvhasználatban is elterjedt a blokk szónak ez a jelentése.

${ }^{68}$ A felvidéki, a muravidéki és az őrvidéki magyar nyelvhasználatban is elterjedt a katedra szó 'tanszék' jelentése.
} 
lemben használatos, a szivar pedig 'cigaretta' denotatív értékű, amint ez az Értelmező kéziszótár második kiadásában is adatolt (Pusztai 2003). Az ilyen esetekben nem annyira kontaktushatással van dolgunk, hanem inkább nyelvjárási jelenséggel.

\section{Specifikus jelentések kialakulása}

A magyarországi köznyelv és az erdélyi magyar nyelvváltozatokban adatolható idegen szók és kölcsönszók egyik leggyakoribb jelentésbeli eltérése abban mutatkozik, hogy Erdélyben és általában a határon túli nyelvváltozatokban szükebb, specifikusabb denotatív jelentésekkel is találkozunk. Ezek a szűkebb fogalomkörü jelentések rendszerint a többségi nyelvből származnak, másodlagos jelentéskölcsönzéssel. A vizsgálatok azt jelzik, hogy többféle módon is érvényesül a szűkebb denotatív értékű jelhasználat.

Az egyik leggyakoribb formája abban nyilvánul meg, hogy a közmagyar vagy magyar szaknyelvi jelentések nem közismertek a kisebbségi régióban, az adott kölcsönszavaknak többnyire csak egy jelentése elterjedt. Amint ezt az 5. táblázat adatai szemléltetik.

Az különböző erdélyi magyar nyelvváltozatokban olyan jelentésgyarapodással is találkozunk, amelyekben az új jelentés a jelölt fogalom tekintetében szűkebb körü ugyan, mégsem tekinthetjük egyértelmüen jelentésszűkülésnek, mivel a szó más jelentései is ismertek és használtak, hanem inkább a többértelmű szó újabb jelentéssel való bővülésének: ilyen a formál '(telefonszámot) tárcsáz', illetve a kód 'postai irányítószám'. Az ilyen eseteknél minden bizonnyal olyan román nyelvi hatással van dolga, amelyeknek forrásai kollokációs szerkezetek, mivel román ekvivalensük ilyen jellegú nyelvi szerkezet: r. a forma (număr) 'telefonszámot tárcsáz', cod poștal 'postai irányítószám'. 


\begin{tabular}{|c|c|c|c|}
\hline Lexéma & $\begin{array}{l}\text { Köznyelvi vagy szak- } \\
\text { nyelvi jelentés(ek) }\end{array}$ & $\begin{array}{l}\text { Az erdélyi magyar } \\
\text { nyelvváltozatokban } \\
\text { adatolt jelentés }\end{array}$ & $\begin{array}{l}\text { A román etimon } \\
\text { alapjelentése }\end{array}$ \\
\hline detasál & $\begin{array}{l}\text { 1. 'csapatot előre küld'; } \\
\text { 2. 'értékpapír szelvényeit } \\
\text { levágja'. }\end{array}$ & 'ideiglenesen áthelyez' & $\begin{array}{l}\text { a detaşa 'ideigle- } \\
\text { nesen áthelyez'69 }\end{array}$ \\
\hline indexál & $\begin{array}{l}\text { 'valorizál, a pénzromlás } \\
\text { mértékét hozzáadva szá- } \\
\text { mol ki valamely értéket' }\end{array}$ & $\begin{array}{l}\text { 'alapbért kiegészít (az } \\
\text { infláció függvény- } \\
\text { ében)' }\end{array}$ & $\begin{array}{l}\text { a indexa 'alapbért } \\
\text { kiegészít (az } \\
\text { infláció függvé- } \\
\text { nyében)' }\end{array}$ \\
\hline inspekció & $\begin{array}{l}\text { 1. 'ügyeletes szolgálat } \\
\text { (pl. kórházban)'; 2. 'fel- } \\
\text { ügyelet, felvigyázás'; } 3 \text {. } \\
\text { 'megfigyelés' }\end{array}$ & $\begin{array}{l}\text { 'hivatalos ellenőrzés } \\
\text { (intézményeknél) }\end{array}$ & $\begin{array}{l}\text { inspecție 'hivata- } \\
\text { los ellenőrzés' }\end{array}$ \\
\hline talon & $\begin{array}{l}\text { 1. ' szelvény, szel- } \\
\text { vényutalvány'; } 2 \text {. 'letét } \\
\text { (kártyajátékban)'; } \\
\text { 3. 'tartalék, vésztartalék' }\end{array}$ & 'forgalmi engedély' & $\begin{array}{l}\text { talon (de înscriere) } \\
\text { 'forgalmi enge- } \\
\text { dély' }\end{array}$ \\
\hline tituláris & 'címzetes' & $\begin{array}{l}\text { 'állásban véglegesített } \\
\text { pedagógus' }\end{array}$ & $\begin{array}{l}\text { (profesor) titular } \\
\text { 'állásban végle- } \\
\text { gesített pedagó- } \\
\text { gus' }\end{array}$ \\
\hline
\end{tabular}

5. táblázat. Szúkebb jelentésben elterjedt lexémák az erdélyi magyar nyelvoáltozatokban

Előfordul, hogy egy adott lexémának azért mondhatjuk, hogy szükebb a fogalmi köre, mert az adott regionális köznyelvben csak egy bizonyos jelentésében elterjedt, más jelentései kizárólag szaknyelvekben jelentkeznek, nem közismertek. Ilyen például a rekuperáció, amely az erdélyi magyar beszélők számára elsődlegesen 'orvosi rehabilitáció' jelentésü, és csak a kémiai vagy fizikai szaknyelvben szerepel 'vegyi és technológiai folyamatokban egyes anyagok visszanyerése, illetve energia-visszanyerés' értelemben

Egy másik formája a szükebb jelhasználatnak a poliszém lexémák konkrétabb fogalomkörökkel való gazdagodása. A kabinet szó például Felvidéken 'kutatóintézeti részleg, szakosztály' és 'valamely intézmény módszertani részlege, szakosztálya' jelentésben is használatos a közmagyar jelentések mellett.

\footnotetext{
${ }^{69}$ A román nyelvi jelentéseket a román értelmező szótárban, a DEX-ben ellenőriztem (DEX 1998.)
} 


\section{Jelentésbővülés az átadó nyelv hatására}

A másik leggyakoribb szemantikai jelenség abban mutatkozik meg, hogy a többségi nyelv hatásának köszönhetően új jelentésekkel gyara podik egy olyan lexéma, amely az erdélyi nyelvváltozatokban is többértelmü, poliszém jellegü. Tehát ilyen esetben a többértelmü hangalak jelentésgyarapodása egyértelmüen az államnyelv hatásával magyarázható (6. táblázat).

\begin{tabular}{|c|c|c|c|}
\hline Lexéma & Köznyelvi jelentései & $\begin{array}{l}\text { Az erdélyi magyar } \\
\text { nyelvváltozatokban } \\
\text { adatolt jelentés }\end{array}$ & $\begin{array}{l}\text { Az analóg román } \\
\text { lexéma alapjelentése }\end{array}$ \\
\hline blokk & $\begin{array}{l}\text { 1. 'valamely összetett } \\
\text { szerkezet egysége; } 2 \text {. } \\
\text { 'tömb'; } 3 \text {. 'elöregyártott } \\
\text { épületelem'; } 4 \text {. 'házak } \\
\text { csoportja'; } 5 \text {. 'írótömb', } \\
\text { 6. 'egyszerü számla' }\end{array}$ & 'panelház; tömbház' & $\begin{array}{l}\text { bloc } \\
\text { 'panelház; tömbház' }\end{array}$ \\
\hline butélia & $\begin{array}{l}\text { 1. 'hosszú nyakú } \\
\text { palack'; } 2 . \text { 'pálinkás- v. } \\
\text { borosüveg' }\end{array}$ & 'palack; gázpalack' & $\begin{array}{l}\text { butelie } \\
\text { 'palack, gázpalack' }\end{array}$ \\
\hline diffúzor & $\begin{array}{l}\text { 1. 'csővezeték'; 2. 'átlát- } \\
\text { szó felület' }\end{array}$ & 'hangszóró' & difuzor 'hangszóró' \\
\hline diploma & $\begin{array}{l}\text { 1. 'birtokadományo- } \\
\text { zó oklevél; 2. 'díszes } \\
\text { hatósági oklevél'; } 3 . \\
\text { 'felsőfokú szakképzett- } \\
\text { séget igazoló oklevél' }\end{array}$ & $\begin{array}{l}\text { 1. 'elismerő oklevél'; } \\
\text { 2. 'iskolai bizonyít- } \\
\text { vány' }\end{array}$ & $\begin{array}{l}\text { diploma } \\
\text { 1. 'elismerő oklevél' } \\
\text { 2. 'iskolai bizonyít- } \\
\text { vány' }\end{array}$ \\
\hline kabinet & $\begin{array}{l}\text { 1. 'kisméretü szoba'; } 2 . \\
\text { 'kabinetszekrény'; } 3 . \\
\text { 'szakterem'; 4. 'kor- } \\
\text { mány testülete' }\end{array}$ & $\begin{array}{l}\text { 'rendelőintézet; orvo- } \\
\text { si rendelő' }\end{array}$ & $\begin{array}{l}\text { cabinet (medical) 'or- } \\
\text { vosi rendelö' }\end{array}$ \\
\hline kalorifer & $\begin{array}{l}\text { 1. 'épület központi lég- } \\
\text { fütéses berendezése'; } \\
\text { 2. 'kaloriméter mükö- } \\
\text { déséhez szükséges, } \\
\text { ismert hőmennyiség } \\
\text { átadására alkalmas } \\
\text { eszköz' }\end{array}$ & $\begin{array}{l}\text { '(melegvízzel műkö- } \\
\text { dő) fütőtest' }\end{array}$ & calorifer 'fütőtest' \\
\hline kancellár & $\begin{array}{l}\text { 1. 'miniszterelnök, } \\
\text { kormányfö'; } 2 . \text { 'magas } \\
\text { rangú állami vagy egy- } \\
\text { házi tisztségviselő' }\end{array}$ & $\begin{array}{l}\text { 'egyetemi tudomá- } \\
\text { nyos titkár' }\end{array}$ & $\begin{array}{l}\text { cancelar }(u l) \text { universi- } \\
\text { tății } \\
\text { 'egyetemi tudomá- } \\
\text { nyos titkár' }\end{array}$ \\
\hline
\end{tabular}




\begin{tabular}{|l|l|l|l|}
\hline lektor & $\begin{array}{l}\text { 1. 'szövegszerkesztö; } \\
\text { 3. 'kéziratokat véle- } \\
\text { ményező személy'; } 4 . \\
\text { 'idegen nyelvet oktató } \\
\text { tanár egyetemen vagy } \\
\text { főiskolán' }\end{array}$ & & 'egyetemi adjunktus' \\
\hline
\end{tabular}

6. táblázat. A többértelmü, idegen eredetū szók jelentésgyarapodása az államnyelvi hatás következtében

Megjegyzendő, hogy a közmagyar és az erdélyi magyar nyelvhasználati különbségek olykor nemcsak a denotatív jelentés módosulásában mutatkoznak meg, hanem a nyelvi regiszter tekintetében is, hiszen a táblázatban szereplő diffúzor vagy a kalorifer Magyarországon kimondottan szaknyelvi jellegü, Erdélyben pedig már-már köznyelvinek minősíthető.

Olykor a poliszém alak több jelentéssel is gyarapodik, amint ezt a komplex szó használatában tapasztalhatjuk. Az Idegen szavak szótára (Tolcsvai 2007) a komplex következő jelentéseit tartja számon: 1. 'összetett, sokrétü', 2. 'átfogó', 3. 'több tudományág módszereit egyesítő'. A Ht-online lexikai adatbázisban pedig a következő szócikket találjuk:

\section{komplex}

1. Ép Okt Er (id) (közh) (köz) olyan (kül. diákszállókból álló) épületcsoport, ahol étkezde és más közellátási intézmény is van. Kiadós zuhany után, hajnalra értünk haza a diáknegyedbe, valami hatalmas kerülövel (valahol a 3-as majd 7-es villamos vonalán, Sági út, Gyiroki út, Stadion - onnan szivárogtunk be a komplexbe). (lektur.transindex.ro)

2. Ép Ker Er (id) (közh) (köz) többféle üzletből álló kereskedelmi egység

3. Ép Ker Müsz Er (id+nép) (közh) (köz) több mühelyt magában foglaló szolgáltató egység.

A román nyelvi hatást jelzi, hogy a román a complex főnévnek 'a közös célt szolgáló épületcsoport' jelentése közismert (DEX). Ebből az adatsorból is jól látható, hogy nemcsak új, más jelentésekről van szó, hanem szófajváltásról is, hiszen a komplex a magyar köznyelvben mellékévi használatú, az erdélyi regionális köznyelvben pedig főnévi értékben is gyakran előfordul.

A jelentésgyarapodás olykor csak egy újabb jelentésárnyalat megjelenésében észlelhető, amint azt a konveniál ige használata mutatja, amely a közmagyar 'tetszik valami, valakinek valami a kedvére van' jelentés mellett Erdélyben elöfordul 'összhangban van valamivel' értelemben is, ahogy 
azt az internetes adatbázis példamondata is megerősíti: ...(a) terv egyúttal konveniál a szabad identitásválasztás modern politikai eszményével.

\section{Metonimikus jelentéseltérések}

A jelentésbeli különbségek másik csoportja a metonimikus viszonyba állítható fogalmi eltérések. Valószínúleg itt sem a magyarban létrejött jelentésekről van szó, hanem inkább más nyelvből származó jelentéskölcsönzésről, amint ezt a 7. táblázat adatai jelzik.

\begin{tabular}{|c|c|c|c|}
\hline Lexéma & Köznyelvi jelentései & $\begin{array}{l}\text { Az erdélyi magyar } \\
\text { nyelvváltozatokban } \\
\text { adatolt jelentés }\end{array}$ & $\begin{array}{l}\text { Az analóg román } \\
\text { lexéma jelentése }\end{array}$ \\
\hline katedra & $\begin{array}{l}\text { 'tantermi dobogó és } \\
\text { tanári asztal' }\end{array}$ & 'tanári állás' & $\begin{array}{l}\text { catedră 'tanári } \\
\text { állás' }\end{array}$ \\
\hline kollektív & $\begin{array}{l}\text { 1. 'halmazból álló'; } \\
\text { 2. 'közös, együttes, egy } \\
\text { csoportra, közösségre } \\
\text { jellemző; } \\
\text { 3. 'általános' }\end{array}$ & $\begin{array}{l}\text { 1. 'közösség', 'mun- } \\
\text { kaközösség'; } \\
\text { 2. 'mezőgazdasági } \\
\text { termelőszövetkezet' }\end{array}$ & $\begin{array}{l}\text { colectiv 1. 'cso- } \\
\text { port, közösség', } \\
\text { 2. 'téesz' }\end{array}$ \\
\hline konszignáció & $\begin{array}{l}\text { 1. 'kimutatás'; 2. 'valamit } \\
\text { engedélyező aláírás'; } 3 . \\
\text { 'írásbeli utasítás áruk } \\
\text { eladására'; } \\
\text { 4. 'bizomány' }\end{array}$ & 'bizományi bolt' & $\begin{array}{l}\text { consignație 'bizo- } \\
\text { mányi bolt' }\end{array}$ \\
\hline delegáció & 'küldöttség' & 'hivatalos kiszállás' & $\begin{array}{l}\text { delegație 'küldött- } \\
\text { ség'; 'hivatalos } \\
\text { kiszállás' }\end{array}$ \\
\hline
\end{tabular}

7. táblázat. Fogalmi érintkezésnek tekinthető jelentésbeli viszonyok a közmagyar és a kisebbségi magyar nyelvoáltozatok szóhasználatában

Ezek a jelentésbeli eltérések olyan metonimikus viszonyokkal, fogalmi érintkezésekkel ragadhatók meg, mint a tárgy és a tárgyhoz kapcsolódó foglalkozás érintkezése ( katedra 'tanári asztal' -'tanári állás'), a tulajdonság és a tulajdonság hordozójának fogalmi ka p csolata (kollektív 'egy közösségre, csoportra jellemző' - 'közösség'), a cselekvés tárgya és a cselekvés helyének érintezése (konszignáció 'letét, bizomány' - 'bizományi bolt') a cselekvő és a cselekvés fogalmi kapcsolata (delegáció 'küldöttség ' - 'hivatalos kiszállás'). 


\section{Generalizálás: elvontabb jelentések kialakulása}

A szó fogalmi jelentésének elvon tabb,általán os abb használatára kevés adatunk van. Más nyelvpárok szemantikai természetű kontaktusjelenségeiből is tudjuk, hogy ez a jelenség sokkal ritkább más típusú jelentésmódosulásokhoz képest, mivel az idegen szónak vagy az újabb keletü kölcsönszavak szemantikai meghonosodására nagyobb mértékben jellemző a jelentésspecializálódás, mint az eredeti jelentés általánosabbá vagy elvontabbá válása (Benő 2004a). Ebbe a ritkábban érvényesülő szemantikai viszonyba sorolhatjuk a kisebbségi nyelvváltozatokban használt licencia és a grafikon szavak jelentésének viszonyát a közmagyarnak tekinthető jelentésekhez. Itt is a többségi nyelvből származó jelentésekkel találkozunk (8. táblázat).

\begin{tabular}{|c|c|c|c|}
\hline Lexéma & Köznyelvi jelentései & $\begin{array}{c}\text { Kisebbségi magyar } \\
\text { nyelvváltozatokban } \\
\text { adatolt jelentés }\end{array}$ & $\begin{array}{l}\text { Az analóg román } \\
\text { lexéma jelentése }\end{array}$ \\
\hline licencia & $\begin{array}{l}\text { 1. 'szabadalom '; 2. 'gyár- } \\
\text { tási engedély'; 3. 'autóver- } \\
\text { senyző vezetối engedélye' }\end{array}$ & 'engedély' & $\begin{array}{l}\text { licență 'gyártási en- } \\
\text { gedély'; 'engedély' }\end{array}$ \\
\hline grafikon & $\begin{array}{l}\text { grafikon: } 1 . \text { 'mennyiségi } \\
\text { viszonyokat, összefüggé- } \\
\text { seket szemléltető ábra', } 2 . \\
\text { 'munkarendet, menetren- } \\
\text { det időpontokra lebontva } \\
\text { ábrázoló rajz' }\end{array}$ & 'menetrend' & grafic 'menetrend' \\
\hline
\end{tabular}

8. táblázat. Idegen eredetü szók elvontabb, általánosabb használata a határon túli magyar nyelvoáltozatokban

Következtetésként megállapítható, hogy a jelentésszűkülés és a jelentésbővülés (generalizálás) aszimmetrikus jelentésváltozási folyamatok a nyelvi érintkezésekben abban a tekintetben, hogy a jelentésszükülés gyakoribb jelentésváltozási tendencia a kontaktusok folyamatában, miközben a generalizálás, az elvontabbá válás sokkal ritkábban, szinte kivételszerüen fordul elő. 


\section{6. Értékjelentés-módosulás}

Olykor Erdélyben és más külső régiók nyelvhasználatában jelentkező idegen szók értékjelentés tekintetében különböznek a szélesebb körben ismert jelentésektől. Ez a folyamat leginkább pejoratív irányba történő jelentésmódosulásban jelentkezik. Így a voluntarisztikus Erdélyben és Felvidéken nemcsak az 'akaratot előtérbe helyező ember'-t jelöli, hanem 'önkényes(kedő) ember'-t is. Hasonlóképpen a felvidéki adatok szerint a benevolens nem mindig 'jóindulatú, jóakaratú személy'-re utal, hanem 'elnézö, engedékeny ember'-re is. Ugyanígy a flegma valamennyi kisebbségi régióban 'nagyképü személy' jelentésben is használt az általánosan elterjedt 'közömbös'; 'hidegvérü' jelentés mellett. Ugyanezt tapasztaljuk a fond lexéma használatában mutatkozó különbségek vizsgálatánál. A szó Erdélyben, Felvidéken, Vajdaságban, Kárpátalján és Horvátországban 'pénzalap' jelentésben is előfordul, és nem csak szaknyelvi regiszterekben, míg a magyarországi nyelvhasználatban kimondottan szaknyelvi jellegü és 'levéltári egység, irategyüttes' értelemben adatolható.

\section{Nagyobb mértékben eltérő jelentésviszonyok}

Ugyanannak a hangalaknak a magyarországi és a külső régióbeli magyar nyelvhasználatban nagymértékben eltérő, különböző fogalmi jelentésben való megjelenésére viszonylag kevés adatunk van. Ilyen a blattol, amely Magyarországon 1. 'zenedarabot első látásra lejátszik vagy elénekel kottából'; 2. 'kártyázik ' jelentésben használatos, míg az erdélyi nyelvhasználatban akkor fordul elő, ha arra kíván a beszélő utalni, hogy valaki 'érvényes menetjegy nélkül utazik'. A jelentésbeli különbség értelmezésében egy ugyanolyan jelentésü román kollokációs szerkezet (a face blat) hatását feltételezhetjük. Ugyanígy a diéta a Felvidéken és Örvidéken 'napidij' jelentésü, míg a közmagyarban 'meghatározott egészségügyi szempontok szerint előírt étrend'. A különbség a külső régiók hagyományőrzőbb természetével is összefüggésben van, hiszen a konduktor Kárpátalján és Erdélyben 'jegyellenőr (tömegközlekedési járaton, helyi érdekü vasúton)' jelentésü, míg Magyarországon ez a jelentés elavultnak minősíthető, de megjelenik más értelemben - igen nagy számban az internetes adatok szerint - 'mozgássérültekkel foglalkozó gyógypedagógus, gyógytornász' jelentésben.

Az azonos hangalakú lexémák eltérő denotatív értékü használata a különböző regiszterekbe való tartozásra is utalhat. Ezt jelzi a komposztál ige erdélyi népnyelvi jelentése: '(lyukasztással) vonaljegyet kezel a buszon' és a magyarországi, főleg a mezőgazdasági szaknyelvi jelentésvonatkozása: 
'(szárazföldi, kerti hulladékot) komposzt készítése céljából (földdel, mütrágyával keverve) rétegesen lerak és nedvesítve érlel'.

\section{Alakváltozatok és jelentéskülönbségek}

Amint szó volt róla, Erdélyben és általában a külső régiókban használt magyar nyelvváltozatokban számos olyan hangalakvariánssal találkozunk, amelyek a hangszerkezet szempontjából igen közel állnak a közismert idegen szavakhoz, mégis sokszor nehéz eldönteni, hogy alakváltoza tokkal van dolgunk, vagy pedig egy másik, hasonló hangalakú szóval. Ennek a kérdésnek a tisztázása, amint látni fogjuk, a szemantikai viszonyok feltárását is érinti, és általános nyelvészeti tanulságai is vannak. A továbbiakban ezeknek a különböző fokú rokonságokra és ezek problematikus viszonyára találunk adatokat.

Az alábbi párhuzamos adatokat bizonyára alakváltozatoknak tekinthetjük, mivel jelentésük megegyezik, és származásuk is közvetett vagy közvetlen módon ugyanarra az etimonra megy vissza: gripa 'meghủlés, influenza' (Er, Va, Hv, Mv) - grippé 'ua.'; decsízió 'végzés, jogi döntés' (Er) decízió 'ítélet, határozat, döntés'; budzset 'költségvetés' (Er, Va, Hv) - büdzsé 'költségvetés'; doszár 'irattartó, dosszié' (Er) - dosszié 'irattartó'; dóza 'adag' (Er, Va) - dózis 'ua.'.

Ám vannak olyan alakváltozatok is, ahol kisebb mértékű különbségeket találunk a hasonló hangalakú szavak jelentésszerkezetében: a kisebbségi nyelvváltozat többletjelentéssel gyarapodott, vagy pedig némileg általánosabb jelentésárnyalatú a köznyelvi hasonló hangalakú és jelentésű párjához képest:

bufet 1. 'falatozó, talponálló' (Er, Va, Ka), 2. 'kocsma' (Er) - büfé 'talponálló'

bilánc (Er) 1. 'egyenleg '; 2. 'cégek évi pénzügyi kimutatása'-bilanz 'vagyonmérleg, mérleg'

borderó 'kimutatás, kísérőjegyzék' (Er) - bordereau 'értékpapírok jegyzéke'

kontakt (Er) 1. 'elektromos érintkezés'; 2. 'összeköttetés, kapcsolat'; 3. 'elérhetőség' - kontaktus 1. 'elektromos érintkezés'; 2. 'emberi kapcsolat'; 3. 'segítő kapcsolat, protekció'.

Az ilyen esetben a jelentések összefüggnek, és éppen úgy lehet osztályozni őket, mint egy többértelmű, poliszém hangsor vizsgálatakor. Kérdéses, hogy az ilyen jellegü, hasonló alakú, de jelentésben némileg különböző szóalakokat alakváltozatoknak tekinthetjük-e, lévén, hogy az 
alakváltozatok esetében a fogalmi jelentések azonossága magától értetődő feltétele annak, hogy alakváltozatokról beszéljünk.

Az alakváltozatoknak látszó lexémák jelentéskülönbsége olyan nagymértékủ is lehet, hogy a hasonló hangalakú szavakat különböző lexikai és lexikográfai egységekként kell számon tartanunk:

kartella 1. 'élelmiszerjegy, étkezdei jegy'(Er); 2. 'a mobiltelefon feltöltőkártyája' (Er) - kartell 1. 'kereskedelmi vállalkozások közötti megállapodás a piac felosztásáról'; 2. 'megegyezés (pl. az államok között)'.

Mindez arra enged következtetni, hogy az alakváltozatok és a hasonló hangalakú, de többé-kevésbé eltérő szavak elkülönítése a konkrét adatok szintjén problematikus lehet, és jogosan feltételezhetjük, hogy skálaszerü, fokozatos átmenet van a két jelenség között, mivel olyan olyan lexikai egységeket is találunk, amelyek alakváltozatoknak tűnnek, de jelentésük némileg eltérő. Az azonban továbbra is kérdés, hogy az ilyen adatokat alakváltozatoknak tekinthetjük-e, lévén, hogy nem elégíti ki a klasszikus értelemben vett alakváltozatnak azt a kritériumát, hogy a denotatív jelentések azonosak legyenek (mint például a fent-fönt, veder-vödör esetében).

Következtetésként megállapítható, hogy az erdélyi és általában a Kárpát-medencei kisebbségi magyar nyelvváltozatok és a közmagyar idegenszó-használatában mutatkozó különbségek bizonyos szemantikai viszonyokba rendezhetően leírhatók, és ezek a különbségek rendszerint a többségi nyelvekből származó szemantikai hatásként értelmezhetők. Az adatok ugyanakkor azt is jelzik, hogy a külső régiók magyar nyelvváltozatainak leggyakrabban használt idegen- és kölcsönszórendszere nem különül el élesen a magyarországi köznyelvtől, és számos párhuzamos jelenséggel találkozunk a különböző nyelvi hatásoknak kitett magyar nyelvváltozatok tekintetében. 



\section{MONDATTANI KÉRDÉSEK}

A kontaktusjelenségek kevésbé vizsgált területe a mondatszintü nyelvi érintkezések kérdésköre (Benő 2008). Mondattani jelenségnek tekinthető a mondat és a mondategységek, szószerkezetek struktúráját érintő nyelvi folyamatok: a szórend, a szintagma elemeinek viszonya, vonzatstruktúra, az egyeztetési (kongruencia) kérdések és a szintaktikai természetü tükörszerkezetek megjelenése a tagmondatok határán. A továbbiakban ezeket a mondattani jelenségeket veszem számba a román nyelvi hatás szempontjából.

\section{Szórendi jelenségek}

A mondattani kontaktusjelenségek területén a szórendi hatások a legerőteljesebbek és a legfeltűnőbbek (Zsemlyei 1977: 194-95). A románra jellemzőnek mondható az SVO (alany + igei állítmány + tárgy) szórend, a magyarban pedig természetesebb a semleges SOV (alany + tárgy + igei állítmány) mondatszerkezet. Ez a különbség megmutatkozik a kontaktusjelenségek körében is.

A közoktatásban dolgozó magyartanárok jelezték, hogy a diákok írott és beszélt nyelvi megnyilatkozásaikban gyakran jelentkeznek olyan szórendi zavarok, amelyek román eredetú kontaktusjelenségnek tekinthetők (Vicsai 2007, Bohonyi 2011). A következő, általános iskolások fogalmazásaiból vett hiteles példamondatok szemléltetik ezt a jelenséget:

"Elment vásárolni cipôt a városba az édesanyjával."

"Szereplöje a mûnek, a kisfiú, testvérei, az anya és István bácsi."

„Késóig sokat tanultam a holnapi matekdolgozatra." (Bohonyi 2011: 49). 
Nemcsak az iskolások nyelvhasználatában figyelhetők meg ilyen jellegü szokatlan szórendủ szerkezetek , hanem a közéleti megnyilatkozásokban is. Szilveszter közeledtével az erdélyi magyar nyelvű rádiók műsoraiban hallhatók olyan jókívánságok, mint: Kívánok egy boldog új esztendőt! (< r. Vă doresc un an nou fericit!), ahol a normatív nyelvhasználattól eltérő szórend mellett a fölöslegesnek tűnő határozatlan névelőt is megfigyelhetjük.

Az erdélyi szórványvidékeken informális nyelvhasználatban, főleg a romándomináns fiatalok nyelvhasználatában gyakori fatikus nyelvi szerkezet a Mit még csinálsz? 'Hogy vagy?' Ez a kérdő mondat mind szórendileg, mind lexikailag hűen követi a r. Ce mai faci? kapcsolatteremtő funkciójú kérdő mondat szerkezetét. A szerkezet idegenszerűségét és gyakoriságát jelzi, hogy a sajtóban is jelennek meg ezzel kapcsolatban elmarasztaló vélemények:

Ehhez pedig nem kell román tagozatra járatni a gyereket, aki aztán elfelejti, hogy a magyar nyelvben hosszú magánhangzók is léteznek, a szavak első szótagjára fektetjük a hangsúlyt, és nyelvtanilag nem helyes az, ha úgy érdeklödünk valaki hogyléte felól, hogy "mit még csinálsz?” (Hajnal Csilla: A „mit még csinálsz” generáció). ${ }^{70}$

Sok diákra rá is fér az ékesszólás müvészetének tanitása, bár rengetegen még nyelvtanilag sem tudnak helyesen megszólalni. Elóbb azt kellene megtanitani nekik, hogy magyarul nem használunk olyan szóösszetételt, mint az, hogy „mit még csinálsz", illetve a "faktura" az magyarul számla és még sorolhatnám. (P. István) ${ }^{71}$

A szórendi kérdések egy része relatív kontaktusjelenségnek tekinthető, abban az értelemben, hogy nemcsak a kontaktusváltozatban fordulnak elő, hanem a standard köznyelvben is, ám a kontaktusváltozatban a gyakoriságuk nagyobb mértékú. A hatást gyakorló nyelv valamilyen grammatikai szabálya megerősíthet, előnybe részesíthet bizonyos nyelvi változót.

A magyarban például a főnévi igenévből és a segédigéből álló szókapcsolatban kétféle szórend lehetséges: 1 . fônévi igenév + segédige (pl. játszani fog, elmenni készül), 2. segédige + főnévi igenév (fog játszani, készül elmenni). Az első szórendi változó a megszokott, a jelöletlen a magyar köznyelvben. A második szórendi változó jelölt abban az értelemben, hogy a fő́névi igenév vagy egy más bővítmény hangsúlyos (pl. fog ez menni; most kell válaszolni). Az indoeurópai nyelvekben általában a segédige + főnévi

\footnotetext{
${ }^{70}$ Vásárhelyi Hírlap: http://www.szekelyhon.ro/images/editions/392/3923/3923_19955.pdf [2013]

${ }^{71}$ http://www.szh.ro/sms-e-mail-velemeny/marosszek/2011-majus-6-pentek [2013]
} 
igenév szerkezet használatos. Ez a nyelvi jelenség hatással lehet a kontaktushelyzetben élő kétnyelvü magyar beszélők választásaira abban az értelemben, hogy nagyobb arányban részesítik előnyben a jelölt szórendet a nyelvi érintkezés eredményeként. Az 1995-96-os RSS-kutatás ezt a szórendi kérdést is vizsgálta. A felmérés átlagos eredményei azt jelzik, hogy a kisebbségi, kontaktushelyzetben élő adatközlők gyakrabban választották a nem standard formát, mint a magyarországi megkérdezett beszélők, és a különbség statisztikai értelemben szignifikáns (Göncz 1999: 175-176).

Hasonló módon gyakorisági eltéréseket mutattak ki a kisebbségi helyzetben élő magyar alanyok és a magyarországi megkérdezettek preferálásában a jelzős szerkezetek (pl. a falon levő tábla) és a hátravetett jelzői értékü határozók (pl. tábla a falon) tekintetében. A szignifikáns különbségek azt jelzik, hogy a megkérdezett kisebbségi magyar beszélők gyakrabban választották a hátravetett jelzői értékü határozót, tehát azt a szerkezetet, amely a szláv és a neolatin nyelvek szintaktikai sajátossága (vö. Lanstyák 2000: 209-211.). Ez megerősíti azt a feltételezést, hogy az ilyen eltéréseknél is számolnunk kell a többségi nyelv közvetett hatásával.

\section{Vonzatkölcsönzés}

Vonzatkölcsönzésnek nevezzük valamely alárendelt, vonzatos szószerkezet más nyelv grammatikai mintájára való használatát. Az alárendelt szószerkezetekben az alaptag és a determináns viszonya nyelvenként eltérő grammatikai viszonyban fejeződik ki. Ez a jelenség az aktív kétnyelvüek beszédében interferenciához, kontaktushoz vezet. A magyar köznyelvben például a szimpatizál ige az eszközhatározós ragos -val/-vel vonzattal használatos (szimpatizál valakivel). A románban ez a viszony tárgyas esetet igényel: szimpatizál valakit (a simpatiza pe cineva). A nem standard erdélyi magyar nyelvváltozatokban megfigyelhető egyfajta ingadozás a szimpatizál ige vonzathasználatában, mivel mindkét grammatikai változat elterjedtnek tünik az eddigi megfigyelések szerint. ${ }^{72}$ Ebben az esetben a szimpatizál valakit változat vonzatkölcsönzésnek tekinthető.

A vonzatkölcsönzés a kétnyelvüek számára talán a legkevéséb feltünő kontaktusjelenség. Ezért gyakorisága valószínüleg nagyobb, mint ahogy a szórványos adatokból látható. Ezt jelzik a sajtónyelvi kutatásokból származó adatok. Íme, egy példa a jelenség érvényesülésére: ez szolgál alapul

${ }^{72} \mathrm{~Kb} .100$ magyar és idegennyelv szakos erdélyi hallgatót kérdeztem meg a szimpatizál ige használatáról, és az eredmények azt jelezték, hogy mindkét grammatikai változat ismert és használatos, sőt voltak, akik jelentésbeli különbségeket láttak a két grammatikai változat között. 
(...) kiszámításánál ('kiszámításához') (Bukaresti Rádió 2010. nov. 20). ${ }^{73}$ Ebben az idegenszerú vonzat esetében jogosan feltételezhetjük a román hatást, hiszen a románban ugyanez a helyviszony jelenik meg: are ca bază la... szerkezetben.

A román eredményeként olykor belső helyviszony helyett külső helyviszony jelölő ragot találunk: A gyárnál dolgozik ('gyárban') (Péntek 2001); a kollektívnél dolgozott ('téeszben'). ${ }^{74}$ Mivel a román a lucra 'dolgozik' ige külső helyviszonyra utaló vonzattal hazsnálatos, a román hatás feltételezése indokolt.

Néha nem egyszerüen vonzatcsere történik, hanem egy szintetikus szerkezet fölcserélődik egy analitikussal, azaz egy toldalékos névszóval kifejezett szintaktikai viszony névutós szerkezettel helyettesítődik. Néhány példa erre a jelenségre a kolozsvári Szabadság címú újságból: nyítani.

Elemeztük, milyen problémák felé igyekeznek a közvélemény figyelmét iráA kérdést továbbitottuk az olvasó felé.

Vizsgálatainkban a magyarországi sajtóban ez a névutós szerkezet ebben az átvitt értelmü jelentésben nem fordult elő. Ilyen szerkezetekben inkább a problémákra (irányítottuk a közvélemény figyelmét), illetve az olvasónak (továbbitottuk) szintetikus nyelvi forma jelentkezik, ezért valószínü, hogy ennek a széttagoló (analitikus) szerkezetnek az elterjedtsége az azonos grammatikai jelentésű és hasonló grammatikai funkciót betöltő román către elöljáróval lehet összefüggésben.

\section{Kontaktusjelenségek az alany és az állítmány szintjén}

A második nyelvből származó hatás az alany és az állítmány kifejezésében, a két fő mondatrész egymáshoz való viszonyában is jelentkezhet.

Gyakorinak mondható az erdélyi regionális köznyelvben, hogy az általános alany egyes szám második személyű igealakban fejeződik ki, ami nem jellemző a magyar standardra, ám az erdélyi nyelvjárásokban elterjedt, normatív természetű (Péntek 2001), és a román köznyelvben is természetes. Nem tudod, mit csinálj 'Nem tudja az ember, mit tegyen' $(<\mathrm{r}$. $n u$ știi ce să faci). Íme, egy élőnyelvi példa erre a jelenségre:

${ }^{73}$ Magyar nyelvű audiovizuális műsorok monitorizálása (http://www.communitas.ro/ media/9_magyar_nyelvu_audiovizualis_musorok_monitorizalasa-jelentes.pdf) [2013]

${ }^{74}$ Gyula bácsi a suszterség után a kollektívnél dolgozott, naponta feljárt a közeli hegyoldalba tehenet fejni, este a kalibában aludt, majd a hajnali fejés után hazatért. (http://www.hirmondo.ro/ web/index.php/kornyek/3979-Felesgnek-ksznheti-lett.html) [2013] 
Példaként legyen elég annyi, hogy ha elmész az orvosodhoz, mert úgy érzed, menten felfordulsz, könnyen meglehet, hogy teljes árat fizetsz a felírt gyógyszerekért. ${ }^{75}$

Amint ismert, a kell menjek (kell + felszólító módú igelak) típusú segédigés állítmányi szerkezet az erdélyi nyelvhasználatban általánosan elterjedt, és az eddigiekben pusztán regionális jelenségként könyvelték el. É. Kiss Katalin elgondolkodtató érvek alapján felvette annak lehetőségét, hogy ez a predikatív szerkezet is kontaktusjelenség (2009). Bár újabban Magyarországon is terjedőben van ennek a szerkezetnek a használata (Posgay 2000), van némi különbség az erdélyi és a nem erdélyi használatban: Erdélyben a kell segédige után igekötős ige is állhat (kell elmenjek), míg Magyarországon csak az el kell menjek változata fogadható el (É. Kiss 2009), ami jelzi, hogy a szerkezet használata Erdélyben változatosabb, öszszetettebb. Ugyanakkor É. Kiss Katalin szerint ez az állítmányszerkezet, a redukált kötómódú beágyazott mondat általános a balkáni nyelvekben (a románban, a görögben, a bolgárban és az albánban), mivel ezekben a nyelvekben nincs infinitivus, és az infinitivus funkcióját a kötőmód vette át. Ezt a szerkezeti megfelelést szemlélteti a következő román nyelvi mondatok struktúrája:

Vreau ca mâine să vină Ion.

akarom hogy holnap CONJ jöjjön Ion

Trebuie să vină.

Kell CONJ jöjjön

Ezek alapján É. Kiss Katalin úgy véli az idézett tanulmányában, hogy a kell + felszólitó módú igealak szerkezet a balkáni redukált kötőmódú mellékmondat megfelelője; a Balkánról nyugatra terjedő Sprachbund-jelenség, és az erdélyi magyar nyelvhasználatban román eredetű mondattani kontaktusjelenség.

Az alany-állítmány szintjén érvényesülő, kontaktusjelenségnek tűnő sajátosság a létigével használt határozói igeneves szerkezet, amely szenved ő (passzív) grammatikai jelentés fejez ki (pl. a lakás el van adva). A közmagyarban ez a szerkezet csak állapotváltozás eredményét kifejező igékkel természetes. Fenyvesi Anna (2005) az amerikai magyarok beszédében kontaktusjelenségnek tekinti ezt a szerkezetet, ha az angol szenvedő szerkezet mintájára alkalmazzák: pl. a magyar nyelv szépen van beszélve; a mi családunkban a magyar sokat van használva. Fenyvesi felméré-

\footnotetext{
${ }^{75}$ http://szekelycitrom.szhblog.ro/2012/01/13/ami-a-reformbol-mindig-kimarad/ [2013]
} 
sei azt jelzik, hogy az amerikai magyaroknak több mint a fele elfogadhatónak tartja az ilyen szerkezetű mondatokat, miközben a magyarországi adatközlőknek csak egy kis hányada tekintette elfogadhatónak. Ez a relatív kontaktusjelenség Erdélyben is érvényesül a románban gyakori passzív szerkezet hatására, elsősorban a nem standard nyelvváltozatokban. Az erdélyi általános iskolás diákok fogalmazásaiban a magyartanárok gyakran találkoznak találkoznak ezzel a passzív szerkezettel:

"Toldi úgy van bemutatva, mint egy erôs ember."

"Baradlayné egy bátor asszonynak van tekintve."

"A vers szenvedélyes hangon van leírva." (Bohonyi 2011: 59).

Ezek alapján valószínúnek látszik, hogy ennek a predikatív szerkezetnek az érvényesülésében nagyobb gyakoriságában szerepet játszik a román nyelvi hatás, bár ennek egyértelmű bizonyítására további kutatásokra van szükség.

\section{Számbeli egyeztetési jelenségek}

Ismert, hogy a magyar köznyelvben a több részből álló tárgyiasságok rendszerint egyes számban szerepelnek: például a páros testrészek nevei (fáj a lába, nem fájnak a lábai), a gyümölcs- és zöldségnevek kategóriára utaló jelentésben, különösen a mennyiségjelző után (sok banánt vásárolt, nem sok banánokat).

Az említett 1995-96-os RSS-kutatásban ezt a nyelvhasználati szokást is vizsgálták az olyan mondatokkal, amelyekben az adatközlőknek azt kellett eldönteniük, hogy az egyes vagy a többes számú változat a természetesebb, illetve mondatkiegészítéses feladatnál valamelyik alakváltozat mellett kellett állást foglalniuk: Nézd milyen szép banánt/banánokat árulnak az üzletben. Erzsi néninek fáj... a szív..., Kati néninek meg a láb... is fáj... A külső régiókban, kisebbségi helyzetben élő magyar adatközlők az ilyen esetekben is gyakrabban használtak többes számú alakot, mint a magyarországi megkérdezett beszélők, bár az eltérés kismértékű, nem szignifikáns. Feltételezhetjük, hogy itt is relatív kontaktusjelenséggel van dolgunk, hiszen az aktív kétnyelvú vagy államnyelvi domináns beszélők gyakrabban használták a nem standard többes számú formát (Lanstyák 2000: 214).

Erdélyben különösen a sok, a kevés és a többi szót tartalmazó mennyiségjelzős szerkezetekben jelentkezik többes számban a jelzett szó a román hatás következtében. Ez a jelenség megfigyelhető a diákok nyelvhasználatában, amint az alábbi adatok szemléltetik: 
"Nagyon gyakran járok nagyáruházakba, mert ott nagyobb választékok vannak, mint a kisboltokba."

"A többi testvéreim még nem járnak iskolába."

"Minél kevesebb bajok vannak, annál boldogabb vagy."

"Nagyon sok dolgokat gyártottak, ami szennyezte a levegöt."

"És sok más feladatok is vannak." (Bohonyi 2011: 59)

Ugyanakkor internetes megjegyzésekben és megnyilatkozásokban is találunk élőnyelvi adatokat a jelenség érvényesülésére:

Én voltam a falu gyülésén, elsőnek és utoljára. Undorító volt érezni, hogy hogyan veszekedtek a sok emberek. ${ }^{76}$

Életemet, mely egy közönséges emberé s amely feltünés nélkül és szerényen hízódik meg a többi emberek élete között. ${ }^{77}$

Sőt szépirodalmi szövegben is előfordul, ha a szerző a népies nyelvhasználatot is felhasználja atmoszférateremtés céljából:

Akinek szeme van, láthatja, hogy sok emberek jártak itten, de honnan tudhatnám, kicsodák? ha mondok valakit, még bosszújából rájuk gyújtja a házat! (Szenczi László: Korom és korona). ${ }^{78}$

A szokatlan többesszám-használat nemcsak az ilyen fogalomköröknél nyilvánulhat meg, hanem az olyan szavak ragozásában is, amelyek a forrásnyelvi jelzős szerkezetekben rendszerint többes számban jelentkeznek. Ilyen szó például a románban az 'ünnep' jelentésű sărbătoare, amely az olyan jelentésű szintagmákban, mint a magyar húsvéti ünnep, karácsonyi ünnep a románban többes számban használatos (sărbători de crăciuni, sărbători de paşti). Ezt tudva, sejthetjük a következő, csángó beszélőtől származó megnyilatkozás nyelvi modelljét:

Tánc volt karácsony ünnepjein, húsvét ünnepjein. (Ivácsony 2005)

Mind a magyar standardtól eltérő többes számú egyeztetés, mind a több részből álló tárgyiasságokat jelölő főnevek szokatlan többes számú használata jelenleg inkább az interferenciához áll közelebb, mint a grammatikai kölcsönzéshez. Ez azonban nem jelenti azt, hogy szem elől téveszt-

\footnotetext{
${ }^{76} \mathrm{http}: / /$ mpp.sarmasagi.ro/2009/12/20/sarmasagi-illetosegu-kerdesek-az-illetekesek-figyelmebe/ [2013]

${ }^{77}$ http://korunk.org/?q=node/5325 [2013]

${ }^{78} \mathrm{http}: / /$ adatbank.transindex.ro/inchtm.php?akod=5211 [2013]
} 
hetjük ennek vizsgálatát a továbbiakban, mivel kétnyelvüséghez köthető, élőnyelv-használati tendenciáról van szó.

\section{Kontaktusjelenségek a tagmondatok határán}

Szerkezetileg átfogóbb jellegü kontaktusjelenségnek tekinthetjük azokat a más nyelvből származó mondattani hatásokat, amelyek nemcsak a szószerkezetek vagy az egyszerü mondatok szintjén érvényesülnek, hanem az összetett mondatokban a tagmondatok határán is. Az eddigi kutatások két ilyen feltetélezhetően román eredetű szintaktikai jelenséget tártak fel. Az egyik a határozószó (pl. természetesen) + hogy szerkezet, a másik pedig az és (de) nemcsak szerkezet elliptikus használata.

E. Kiss Katalin (2010) mondattani és komparatív nyelvészeti érvek alapján úgy véli, hogy a nem normatív, de terjedőben lévő természetesen, hogy... szerkezet román hatást tükröz. Korábban ezt kontamináció eredményének tekintették, a természetes, hogy... szintaktikai kifejezés és a természetesen módhatározószó keveredésének (E. Abaffy 1976, Sándor 1998), vagy pedig hiányos főmondatú összetett mondatnak, amely az olyan teljes mondatból ered, mint: Természetesen az van, hogy elmegyek (Nemesi 2000). É. Kiss Katalin szerint a következő érvek szólnak a román nyelvi hatás mellett:

1. A szerkezet több szempontból is rendhagyó, és a rendhagyó szerkezetek gyakran nyelvi kontaktusokból erednek.

2. A románban a szerkezet teljesen úgy viselkedik, mint a magyarban: a) a módhatározó egy alárendelő mondat előtt áll; b) a létige nem tehető ki a határozószó előtt; c) a határozószót nem előzheti meg kérdőszó; a szerkezet nem ágyazható be egy másik mondatba; d) a határozókat puszta határozószó képviseli, nem helyettesíthetők összetett határozó szintagmával ( ${ }^{*} \hat{\imath}$ m mod sigur că va veni - *természetes módon, hogy fog jönni).

3. A szerkezet viszonylag új a magyarban (mintegy kétszáz éve létezik).

4. A szerkezet a románban, a franciában és a spanyolban egyaránt megtalálható, ez pedig arra utal, hogy a szerkezet valamilyen latin előzményre megy vissza (É. Kiss 2010 230-235.).

A másik mondatszintü vagy betoldás értékű kontaktusjelenség az és/ de nemcsak elliptikus módú használata. A szerkezet a közmagyarban is megjelenik, de a szerkezet után mindig következik egy visszautaló elem vagy szóismétlés: Az igazgató a rendezvényen sokat beszélt, de nemcsak ö/ az igazgató. Kádár Edit (2010) arra figyelt fel, hogy az erdélyi regionális köznyelvben, különösen a sajtóban a szerkezetben elmarad a visszautaló 
elem, az anafora, akárcsak a románban. Íme egy élőnyelvi példa erre a jelenségre: Varga Zoltán alkotásait évek óta figyeltem, és mindig arra gondoltam, jó lenne egyszer azokat bemutatni a csíkszeredai közönségnek, és nemcsak. ${ }^{79} \mathrm{Ez}$ a kiegészítés nélküli, hiányos szerkezetnek egyértelmű analóg párja van a románban: a și nu numai 'és nemcsak' szerkezet. A jelenség azért is figyelmet érdemel, mert nem valamilyen új nyelvi elem vagy viszony jelenik meg, hanem valami elmarad, és a hiány, az ellipszis is lehet kontaktus eredménye. Mivel ez a kiegészítés nélküli hozzátoldó szerkezet csak az erdélyi nyelvhasználatban fordul elő, és egyértelmű román forrása van, jogosan feltételezhető a román nyelvi hatás.

A bemutatott mondattani jelenségek összetettsége arra utal, hogy a mondat szintű kontaktológiai kutatások számos kérdése még további kutatásra vár, és ezen a területen elengedhetetlenül szükség van az areális alapú komparatív módszerek alkalmazására is.

${ }^{79} \mathrm{http} / / /$ www.hargitatanc.ro/?menu=hirek\&l=hu\&hir=246 [2011] 



\section{X. ÖSSZEGZÉS, KÖVETKEZETETÉSEK}

1. A román-magyar nyelvi érintkezés kutatása számos új eredménnyel gyarapodott az elmúlt két évtizedben, és ezek az újabb felismerések tovább árnyalták, pontosították a korábbi felismeréseket. Az újabb interdiszciplináris megközelítések a szociolingvisztika, a szociálpszichológia és a kognitív nyelvészet perspektívájából lehetővé tették, hogy új szempontok, új felvetések jelenjenek meg a kontaktusok vizsgálatában (Benő 2004a, Horváth 2003, Kádár 2008, 2010, Péntek-Benő 2003b, Péntek 2001, 2006, 2007). Szükség van a továbbiakban a kontaktusjelenségek olyan vizsgálatára, amely a kisebb régiók és a szociológiai változók alapján is értékelni tudja a nyelvi érintkezések folyamatait Erdélyben. A szociológia és a szociolingvisztika ismert mintavételi eljárásainak alkalmazása ehhez jelentős mértékben hozzájárulhat.

2. Hasonlóképpen a nyelvi érintkezések vizsgálatában elengedhetetlen annak a szociolingvisztikai axiómának a szem elött tartása, hogy a nyelv végső soron nyelvváltozatok dinamikus sokasága, és az újabb kontakusjelenségek, rendszerint nem a nyelv egészében, annak minden regiszterében és változatában érvényesülnek, hanem csak bizonyos nyelvváltozatokban, és éppen ennek a szemléletnek érvényesítésében lehet segítségünkre a szociolingvisztikai nyelvszemlélet.

3. Az erdélyi magyar nyelvváltozat nem tekinthető egységesnek a kontaktusok szempontjából sem, hiszen a román hatás intenzitását tekintve legalább három helyzetet különíthetünk el: a legkisebb mértékű tömbhelyzetben (Székelyföldön, ahol a magyarok aránya 50\% fölött van), a legerőteljesebb szórványhelyzetben (Dél-Erdélyben és Közép-Erdélyben, ahol a magyarok aránya $15 \%$ alatti), 3. és közepesnek mondható átmeneti helyzetú régiókban (Maros, Kolozs, Bihar, Szatmár, ahol ez az arány 15-49\% közötti). A regiszterek szempontjából pedig a hivatali és a szaknyelvi re- 
giszterekben a legintenzívebb mind a közvetlen, mind a közvetett kontaktusjelenségek tekintetében (l. ezzel kapcsolatban a IV.1, és az V.fejezetetet). Ennek a beszélők nyelvi kompetenciájával összefüggő jelenségnek nyelvpolitikai és jogérvényesítési okai is vannak (II. fejezet).

4. A nyelvi és etnikai kisebbségi helyzet Erdélyben mind a mai napig bizonyos mértékủ jogfosztottságot jelent az anyanyelvhasználat szempontjából, és ez felerősítette az elmúlt évtizedekben a román nyelv hatásának a mértékét. A nyelvi közösségek korábbi kétoldalú nyelvi érintkezése mára nagyobbrészt egy oldalú vá, a szi m metriku s sá vált. Az egyoldalúság megnyilvánul abban, hogy ma Erdélyben főleg a román nyelv magyarra gyakorolt hatásáról beszélhetünk, és nagyon kismértékben a magyar nyelv hatásáról a románra. Az aszimmetrikusságot az is jelzi, hogy a két nyelvi közösség viszonylatában a közös kód szerepét az államnyelv tölti be, és hogy a kisebbségiek nagy hányada kétnyelvü, míg a többségiek rendszerint egynyelvűek, és így az hivatalos információáramlás egyoldalú (Péntek 1999: 45). Ehhez járul még az a tény, hogy a román nyelv hivatalos jogi státust élvez, míg a magyar nyelv használata korlátozott az oktatásban, az igazságszolgáltatásban, a közigazgatásban, az egészségügyben.

5. A szókölcsönzés eddig ismert indítékai mellet számolni kell még a következő tényezőkkel: a) hangalaki expresszivitás; b) a nyelvspecifikus jelentéskategorizálás hatása; c) nyelvi tabu és hangalaki jelöltség; kisebbségi kétnyelvüség és az ehhez kötődő nyelvhasználati feltételek; d) vizualitás és nyelvi környezet; e) nyelvhasználati gazdaságosságra törekvés (Benő 2008: 173-186, Péntek 2010a, Szilágyi 2007).

6. A kontaktusjelenségeket és a meghonosodás folyamatát leginkább lexikai, lexikográfiai szempontból vizsgálták az eddigiekben, de épp ilyen mértékben szükségesnek látszik a grammatikai szempontok érvényesítése: a morfológiai és a szintaktikai törvényszerúségek további tanulmányozása, és az általánosítható felismerések megfogalmazása (É. Kiss-Hegedűs 2010).

7. Mivel a tulajdonnév-kölcsönzés is kontaktusjelenség, ez a nyelvi folyamat is szerves része a nyelvi érintkezéseknek, és a kontaktológiai általános kérdéseit bemutató kézikönyvek, egyetemi jegyzetek ennek külön fejezetet kell szánniuk, lévén hogy a tulajdonnevek is a nyelvhasználat szerves részét képezik (III.4.1.3). Különösen a román eredetú családnevek történetisége és földrajzi megoszlása kapcsán merülnek fel kellő módon nem tisztázott kérdések

8. Ha a közvetett kontaktusjelenségek vizsgálatát kiterjesztjük valamennyi külső régióra, akkor formális-szerkezeti szempontból azt láthatjuk, hogy összehasonlítva a magyarországi standardban használatos egyenértékú párjukkal, analitikus-szintetikus különbségek mutatkoznak, 
azaz a többségi nyelvek gyakran széttagoló szerkezettel, több szóval fejeznek ki olyan fogalmakat, amelyekre a magyar köznyelvben egyetlen szóval utalnak (V.6).

9. A közvetett nyelvi hatások vizsgálatánál tekintettel kell lennünk arra, hogy nem minden „idegenszerü", a mai magyar hivatali nyelvhasználattól eltérő szó vagy szószerkezet tekinthető kontaktushatásnak, mivel megőrzött régiségek is erőteljesen jelen vannak a mai erdélyi regionális köznyelvben (pl. halotti levél, születési bizonyítvány, hajtási igazolvány, altiszt stb.) (V.7.).

10. Egy másik nyelv hatása bizonyos nyelvhasználati sajátosságok gyakoriságának változásában is megmutatkozik. Ilyen esetekben a kétnyelvű beszélők megnyilatkozásában nem fordulnak elő olyan nyelvi elemek, amelyek az egynyelvüek beszédében ne lennének meg, csupán ezeknek a gyakorisága eltérő (III. 4.2.6).

11. Az ilyen kontaktusjelenségek az indirekt kölcsönzésnél is nehezebben észrevehetők, mivel az egynyelvűek beszédében is előfordul, és a különbségek közvetlenül nem észlelhetők, csak kvantitatív szociolingvisztikai vizsgálatokkal mutathatók ki. Ezek a jelenségek az egynyelvü nyelvváltozatokban teljesen hiányzó, abszolút kontaktusjelenségekhez képest relatív kontaktusjelenségek (Lanstyák 2002: 93). A relatív kontaktusjelenségek abban különböznek az indirekt kölcsönzéstől, hogy ezeknek nincs egyetlen átadó nyelvi modelljük, nem mutatható ki, hogy konkrétan milyen nyelvi jel vagy jelsor hatásra jött létre az átvevő nyelvben az adott nyelvi forma. A relatív kontaktusjelenségek lehetnek morféma-, szószerkezeti vagy mondatszintűek, hiszen a nyelvi változók a legkülönbözőbb grammatikai szerkezetben megjelenhetnek. Ezeknek a tanulmányozásához további felmérésekre van szükség mind Magyarországon, mind Erdélyben, mivel még nincs elég, azonos módszerrel gyűjtött összehasonlítható adatunk.

12. A kontaktusjelenségek tipológiájában célszerü a hibridszerkezeteket és hibridszavakat külön kategóriába sorolni, és nem a közvetett (indirekt) nyelvi hatások körébe, mivel ebben a kontaktusjelenségben a közvetlen morfémakölcsönzés és a tükörfordítás, azaz a közvetlen és közvetett nyelvi hatás egyaránt érvényesül, és így tükörszerkezetek körébe való sorolása megtévesztő lehet (III.4.3).

13. A vonatkozó kutatások azt jelzik, hogy meghonosodó nyelvi elemek alaki integrálódásában szerepet játszik a belehallás, a népetimológia, a szóelvonás, a morfémacsere és az analógia többféle formája (VII.1).

14. A kölcsönelemek jelentésváltozási tendenciáinak elemzése arra utal, hogy a fogalmi jelentéseik ismert logikai viszonyain kívül figyelembe kell venni az emocionális és értékjelentés lehetséges módosulásait, a 
metaforikus és metonimikus jelentésviszonyok változásait. A kognitív szemantikai terminológiai és elemzési kerete új szempontokkal gazdagithatja az átvételek jelentésváltozási folyamatainak rendszerezését (VIII; Benő 2004a, Szilágyi 2007).

15. Viszonylag keveset tudunk a kontaktusjelenségek mondattani vonatkozásairól. Az elmúlt években hiánypótló tanulmányok jelentek meg a román-magyar nyelvi érintkezés szempontjából (Kádár 2010, É. Kiss 2009, 2010). A mondattani felismerések arra utalnak, hogy olykor tágabb kontextusban, több nyelv kontrasztív elemzésével is szükséges végiggondolni a grammatikai hatásokat, hiszen areális sajátosságok is lehetnek az egyirányúnak vélt kontaktusfolyamatok, amint a kell menjek típusú szerkezet jelzi É. Kiss Katalin (2009) vizsgálatai szerint. A szintaktikai kontaktusoknál a hiány, az ellipszis is nyelvi hatásról árulkodhat (IX.3).

16. Az erdélyi magyar nyelvváltozatokban meghonosodó újabb román eredetű lexikai elemek számbavétele, kontaktológiai és szociolingvisztikai keretben történő leírása folyamatos feladata a kutatóknak. A dolgozatomnak is alapjául szolgáló Termini magyar nyelvi szótár és adatbázis az élőnyelvi adatok forrásaként erre sok szempontból alkalmas. 


\section{FELHASZNÁLT SZAKIRODALOM}

E. ABAFFY Erzsébet 1976. Valószínűleg, hogy... Magyar Nyelvớr 100: 397398.

ALEXICS György 1887. Magyar elemek az oláh nyelvben. Magyar Nyelvör XVI. 252 kk.; XVII. 57 kk.

ANDRIC Edit 1995. A szerb nyelvnek a vajdasági magyar nyelvre gyakorolt hatása. In: Kassai Ilona (szerk.) Kétnyelvüség és magyar nyelvhasználat. Budapest: MTA Nyelvtudományi Intézet. 235-43.

ASHER, R. E. (ed.) 1994 The Encyclopedia of Language and Linguistics. vol. 1-10. Oxford - New Zork - Seoul - Tokyo: Pergamon Press.

BAKOS Ferenc 1970. A végartikulus alakulása román jövevényszavainkban. Magyar Nyelv LXVI. 178-82.

BAKOS Ferenc 1980. Kiegészítések Márton Gyula-Péntek János-Vöő István „A magyar nyelvjárások román kölcsönszavai „, című munkájának XX. századi anyagához Magyar Nyelv LXXVI. 479-83.

BAKOS Ferenc 1982. A magyar szókészlet román elemeinek története. Budapest: Akadémiai Kiadó.

BAKOS Ferenc 1984. Román jövevényszavaink legújabb rétegéhez. In: Nagy Béla (szerk.) Magyar-román filológiai tanulmányok. Budapest: ELTE Román Filológia Tanszék. 231-238.

BAKOS Ferenc 1991. Az idegen szavak egy sajátos csoportja: a xenizmus. Magyar Nyelv LXXXVII. 306-12.

BALOGH Ödön 1961. Gyímesi csángó tájszók. Nyelv-és Irodalomtudományi Közlemények V. 73-101. 
BARTHA Csilla 1993. Megjegyzések a lexikai kölcsönzésről. IN: Kozocsa Sándor Géza (szerk.) Emlékkönyv Fábián Pál 70. születésnapjára. Budapest: ELTE Bölcsészettudományi Kara, Mai Magyar Nyelvi Tanszék. 26-35.

BÁLINT Emese 2013. Kétnyelvúség és nyelvi változás a szórványban. Sepsiszentgyörgy: Anyanyelvápolók Erdélyi Szövetsége. Szabó T. Attila Nyelvi Intézet Kiadványai 8.

BÁLINT Emese - PÉNTEK János (szerk.) 2009. Oktatás - nyelvek határán. Közelkép és helyzetkép a romániai magyar oktatásról. Szabó T. Attila Nyelvi Intézet Kiadványai 5. Kolozsvár: Anyanyelvápolók Erdélyi Szövetsége.

BÁRCZI Géza 1958. A magyar szókincs eredete. Budapest: Akadémiai Kiadó.

BENKŐ Loránd 1988. A történeti nyelvtudomány alapjai. Budapest: Akadémiai Kiadó.

BENŐ Attila 2000. Az expresszivitás változásai román eredetű kölcsönszavainkban. Magyar Nyelv 4. sz. 436-445.

BENŐ Attila 2004a. A kölcsönszó jelentésvilága. A román-magyar nyelvi érintkezés lexikai-szemantikai kérdései. Kolozsvár: Erdélyi Múzeum Egyesület.

BENŐ Attila 2004b. Román kölcsönszó - magyar igekötő. P. Lakatos Ilona és T. Károlyi Margit (szerk.) Nyelvvesztés, nyelvjárásvesztés, nyelvcsere. Budapest: Tinta Könyvkiadó. 223-229.

BENŐ Attila (és mtsai) (szerk.) 2004. Magyar-román közigazgatási szótár. Sepsiszentgyörgy: Anyanyelvápolók Erdélyi Szövetsége.

BENŐ Attila 2007a. A hivatali nyelv és a nyelvi tervezés. In: Zelliger Erzsébet (szerk.) Nyelv, területiség, társadalom. A 14. élőnyelvi konferencia (Bük, 2006. október 9-11) előadásai. Budapest: Magyar Nyelvtudományi Társaság. 115-122.

BENŐ Attila 2007b. Köznyelvi magyar szavak jelentésbővülése az erdélyi magyar nyelvváltozatban. Benő Attila - Fazakas Emese - Szilágyi N. Sándor (szerk.) Nyelvek és nyelvváltozatok. Köszöntő kötet Péntek János tiszteletére. I. Kolozsvár: Anyanyelvápolók Erdélyi Szövetsége.145151.

BENŐ Attila 2008. Kontaktológia. A nyelvi kapcsolatok alapfogalmai. Kolozsvár: Egyetemi Múhely Kiadó - Bolyai Társaság.

BENŐ Attila 2009a. Köznyelvi lexikai egységek szemantikai sajátosságai a kisebbségi magyar nyelvváltozatokban. In: Borbély Anna - Vančoné Kremmer Ildikó - Hattyár Helga (szerk.) Nyelvideológiák attitüdök és 
sztereotípiák. Budapest-Dunaszerdahely-Nyitra: Tinta Könyvkiadó. 25-36.

BENŐ Attila 2009b. Újabb lexikográfiai munkálatok és a határon túli magyar nyelvváltozatok vizsgálata. In: Bárdos Vilmos (szerk.) Quo vadis philologia temporum nostrum? Budapest: Tinta Könyvkiadó. 71-77.

BENŐ Attila 2010. Az átvevő nyelv morfológiai rendszerének hatása a népetimológia és a szóelvonás érvényesülésében. In: É. KISS Katalin - HEGEDÚS Attila (szerk.) Nyelvelmélet és kontaktológia. 2010. Piliscsaba: Pázmány Péter Katolikus Egyetem BTK Elméleti Nyelvészeti Tanszék - Magyar Nyelvészeti Tanszék. 197-206.

BENŐ Attila 2011a. Hol beszélnek a legszebben magyarul? In: BALOGH F. András - BERSZÁN István - GÁBOR Csilla (szerk.) Újrateremtett világok. Írások Cs. Gyímesi Éva emlékére. 2011. Budapest: Argumentum Könyvkiadó. 61-70.

BENŐ Attila 2011b Normatudat és nyelvi presztízs. In: Horváth István Tódor Erika Mária (szerk.) Nyelvhasználat, tannyelv és két(több)nyelvú lét. 2011. Kolozsvár: Nemzeti Kisebbségkutató Intézet - Kriterion. 147-162.

BENŐ Attila 2011c Román eredetű családnevek a nyelvterület keleti régiójában. Eredetréteg, tipológia. In: Vörös Ferenc (szerk.) A nyelvföldrajztól a névföldrajzig. Családnév - helynév - kisebbségek. 2011. Szombathely: Savaria University Press. 109-117.

BENŐ Attila 2012. Többségi nyelv és kisebbségi nyelv. Attitűd és normatudat az erdélyi magyarok körében. In: Hires-László Kornélia - Karmacsi Zoltán - Márku Anita (szerk.) Nyelvi mítoszok, ideológiák, nyelvpolitika és nyelvi emberi jogok Közép-Európában elméletben és gyakorlatban. Budapest - Beregszász: Tinta Könyvkiadó - Hodinka Antal Intézet. 257-266.

BENŐ Attila - Bencze Orsolya - Erdélyi Judit - Nagy Zsuzsanna - ÖrdögGyárfás Eszter - Sárosi Márdírosz Krisztina (szerk.). 2004. Magyar-román közigazgatási szótár. Sepsiszentgyörgy: Anyanyelvápolók Erdélyi Szövetsége.

BENŐ Attila - FAZAKAS Emese - Sárosi-Márdirosz Krisztina 2009. Románmagyar oktatásterminológiai szótár. Sepsiszentgyörgy: Anyanyelvápolók Erdélyi Szövetsége.

BENŐ Attila - FAZAKAS Emese - SZILÁGYI N. Sándor (szerk.) 2007. Nyelvek és nyelvoáltozatok. Köszöntő kötet Péntek János tiszteletére. Szabó T. Attila Nyelvi Intézet Kiadványai 4. Kolozsvár: Anyanyelvápolók Erdélyi Szövetsége. 
BENŐ Attila - LANSTYÁK István - JUHÁSZ Tihamér 2010. A Termini magyar-magyar szótár és adatbázis. Régió. 2010. 4. sz. 37-58.

BENŐ Attila - PÉNTEK János 2002. Nyelvi jogok Románában. IN: Nádor Orsolya és Szarka László (szerk.): Nyelvi jogok, kisebbségek, nyelvpolitika Kelet-Közép-Európában. Budapest: Akadémiai Kiadó. 123-147.

BENŐ Attila - PÉNTEK János (szerk.) 2011. A Termini Magyar Nyelvi Kutatóhálózat tíz éve. Nyelvi jogi környezet és nyelvhasználat. 2011. Gramma Nyelvi Iroda - Szabó T. Attila Nyelvi Intézet. Dunaszerdahely - Kolozsvár. 4801.

BENŐ Attila - SZILÁGYI N. Sándor 2005. Hungarian in Romania. In: Anna Fenyvesi (ed.) Hungarian Language Outside Hungary. Amsterdam: John Benjamins Publishing Company. 133-163.

BENŐ Attila - SZILÁGYI N. Sándor (szerk.) 2006. Nyelvi közösségek-nyelvi jogok. Szabó T. Attila Nyelvi Intézet Kiadványai 3. Kolozsvár: Anyanyelvápolók Erdélyi Szövetsége.

BLÉDY Géza 1942. Influenţa limbii române asupra limbii maghiare. Sibiu: Universitatea „Regele Ferdinand I."

BOHONYI Imola 2011. Interferenciák és regionalizmusok az általános iskolás tanulók nyelvhasználatában. I. fokozati tanári szakdolgozat. (Kézirat). Témavezető: Benő Attila.

BULGĂR, Gheorghe - CONSTANTINESCU-DOBRIDOR, Gheorghe 2002. Dicționar de arhaisme și regionalisme. București:Saeculum Vizual.

CSERNICSKÓ István1995. A kárpátaljai magyarság és a kétnyelvűség. In: Kassai Ilona (szerk.) Kétnyelvüség és magyar nyelvhasználat. Budapest. $129-45$.

CSERNICSKÓ István 1998. A magyar nyelv Ukrajnában (Kárpátalján). Budapest: Osiris Kiadó - MTA Kisebbségkutató Mühely.

CSERNICSKÓ István - PÉNTEK János 2011. A határon túli magyar nyelvváltozatok a többségi nyelvpolitikák rendszerében: Románia és Ukrajna példája. In: Benő Attila - Péntek János (szerk.) A Termini Magyar Nyelvi Kutatóhálózat tíz éve. Nyelvi jogi környezet és nyelvhasználat. Dunaszerdahely - Kolozsvár: Gramma Nyelvi Iroda - Szabó T. Attila Nyelvi Intézet. 195-218.

CSÚRY Bálint 1931. Erdélyi magyar nyelvünk állapota. Magyar Nyelv XXVII. 253-8.

DAMIÁN István1912. Adatok a magyar-román kölcsönhatáshoz. Nyelvészeti Füzetek 67: 3-61. 
DEX 1998. Dicționarul explicativ al limbii române. (Red. Ion Cotenau - Luiza Seche - Mircea Seche). Academia Română. București: Univers Enciclopedic.

EDELSPACHER Antal 1876. Rumun elemek a magyar nyelvben. Nyelvtudományi Közlemények. XII. 87-116.

ÉKsz. ${ }^{2}$ Pusztai Ferenc (főszerk.) 2003. Magyar értelmező kéziszótár. Második, átdolgozott kiadás. Budapest: Akadémiai Kiadó.

FAZAKAS Emese (főszerk.) 2002. Román-magyar közigazgatási szótár. Sepsiszentgyörgy: Anyanyelvápolók Erdélyi Szövetsége.

FAZEKAS Tiborc 1995. Családnevek a bukovinai székelyek körében. In: B. Gergely Piroska - Hajdú Mihály (szerk.) Az V. Magyar Névtudományi Konferencia előadásai. Budapest - Miskolc: Magyar Nyelvtudományi Társaság - Miskolci Egyetem Bölcsészettudományi Intézete. 97-100.

FENYVESI Anna 2005. A toledoi magyarok nyelve: Nonstandard nyelvhasználat vagy a nyelvkontaktus hatása? In: Kovács Nóra (szerk.) Magyarok a nagyvilágban: Diaszpórakutatás az ezredfordulón. Budapest: MTA Kisebbségkutató Intézet. 58-73.

FIELD, Friedrich W. 2002. Linguistic borrowing in bilingual contexts. Amsterdam - Philadelphia: John Benjamins Publishing Company.

GÖNCZ Lajos 1999. A magyar nyelv Jugoszláviában (Vajdaságban). Budapest - Újvidék: Osiris Kiadó - Forum Könyvkiadó - MTA Kisebbségkutató Mühely.

GÁL Noémi 2010. A nyelvi revitalizáció. Szabó T. Attila Nyelvi Intézet Kiadványai 6. Kolozsvár: Anyanyelvápolók Erdélyi Szövetsége.

GOTTLIEB, Henrik 2006. Linguistic Influence. In: Brown Keith (ed.) Encyclopedia of language and linguistics. Amsterdam - London: Elsevier, vol. 7. 196-206.

GRAUR Alexandru 1965. Nume de persoane. Bucureşti: Editura Ştiinţifică.

HAJDÚ Mihály 2010. Családnevek enciklopédiája. Leggyakoribb mai családneveink. Budapest: Tinta Könyvkiadó.

HAUGEN, E. 1950. The Analysis of Linguistic Borrowings. Language 26: 210-231.

HEINE, Bernad - KUTEVA, Tania 2005. Language Contact and Grammatical Change. Cambridge: Cambridge University Press.

HOMONAI Judit 204. A diákszleng sajátosságai középiskolások írott szövegeiben. (Mesteri szakdolgozat. Kézirat.)

HORVÁTH István 2003. Az erdélyi magyarok kétnyelvűsége: nyelvmentés és integráció között? Erdélyi Társadalom 1. sz. 7-24. 
HOUGH C. 2006. Place Names. In: Brown, Keith (ed.) Encyclopedia of language and linguistics. Amsterdam-London: Elsevier, vol. 9. 613-620.

HRISTEA, Theodor 1984. Sinteze de limba română. București: Albatros.

IORDAN, Iorgu 1983. Dicționar al numelor de familie românești. București: Editura Științifică și Enciclopedică.

IVÁCSONY Zsuzsa 2005. Mondattani és szövegtani vizsgálat a moldvai csángó nyelvjárásban. In: Kinda István - Pozsony Ferenc (szerk.) Adaptáció és modernizáció a moldvai csángó falvakban. Kolozsvár: Kriza János Néprajzi Társaság. 308-35.

IZSÁK Balázs 2000. A román tanügyi törvény a nemzetközi jog szemszögéből. Magyar Kisebbség 3. sz. 181-204.

JOHANSON, Lars 2008. Remodeling grammar: Copying, conventionalization, grammaticalization. In: Siemund, Peter and Kintana, Noemi (ed.) Language contact and contact languages. Amsterdam -Philadelphia: John Benjamins Publishing Company. 61-80.

KÁDÁR Edit 2008. Nyelvtudományi kutatások Romániában. A KAB kutatásstratégiai munkálataihoz készült jelentés. www.kab.ro

KÁDÁR Edit 2010. ...és (de) nemcsak. In: É. KISS Katalin - HEGEDÚS Attila (szerk.) Nyelvelmélet és kontaktológia. Piliscsaba: Pázmány Péter Katolikus Egyetem, Bölcsészettudományi Kar. 207-221.

KATONA Edit 1995. Interferencia-jelenségek mérése a vajdasági magyar nyelvhasználatban. IN: Kassai Ilona (szerk.) Kétnyelvüség és magyar nyelvhasználat. Budapest: MTA Nyelvtudományi Intézet. 225-234.

KIRÁLY Francisc 1990. Contacte lingvistice. Timişoara: Editura Facla.

KIS Emese 1975. Incadrarea substantivelor de origine maghiară în sistemul morfologic a limbii române. Bucureşti: Editura Academiei R.S.R.

KISS Jenő 1995. Társadalom és nyelvhasználat. Budapest: Nemzeti Tankönyvkiadó.

É. KISS Katalin 2004. Anyanyelvünk állapotáról. Budapest: Osiris Kiadó.

É. KISS Katalin 2009. El kell menni/el kell mennem/el kell, hogy menjek/ el kell menjek/el kellek menni. In: É. Kiss Katalin - Hegedüs Attila (szerk.) Nyelvelmélet és dialektológia. Piliscsaba: Pázmány Péter Katolikus Egyetem, Bölcsészettudományi Kar. 213-230.

É. KISS Katalin 2010. Valószínüleg, hogy román kontaktushatás. In: É. Kiss Katalin - Hegedüs Attila (szerk.) Nyelvelmélet és kontaktológia. Piliscsaba: Pázmány Péter Katolikus Egyetem, Bölcsészettudományi Kar. 223-237. 
É. KISS Katalin - HEGEDÜS Attila (szerk.) 2010. Nyelvelmélet és kontaktológia. Piliscsaba: Pázmány Péter Katolikus Egyetem, Bölcsészettudományi Kar. 197-206.

KNIEZSA István 1941. Erdély földrajzi nevei. Budapest: Athenaeum.

KNIEZSA István 1955. A magyar nyelv szláv jövevényszavai. Budapest: Akadémiai Kiadó.

KONTRA Miklós 1981. A nyelvek közötti kölcsönzés néhány kérdéséröl, különös tekintettel „elangolosodó" orvosi nyelvünkre. Nyelvtudományi Értekezések. 109. Budapest: Akadémiai Kiadó.

KONTRA Miklós 1990. Fejezetek a South Bend-i magyar nyelvhasználatból. Budapest: A Magyar Tudományos Akadémia Nyelvtudományi Intézet.

KONTRA Miklós 2006. A határon túli magyar nyelvváltozatok. In: Kiefer Ferenc (szerk.) Magyar nyelv. Budapest: Akadémiai Kiadó. 549-576.

KÓSA Ferenc 1963. Román nyelvi hatás az erdélyi fazekasmesterség szakszókincsében. Nyelv-és Irodalomtudományi Közlemények VIII. 97-105.

KÓSA Ferenc - VÖŐ István - ZSEMLYEI János 1966. Román kölcsönszavak a moldvai csángó fazekasság szakszókincsében. Nyelv-és Irodalomtudományi Közlemények X. 356-69.

LANSTYÁK István 1998b. A magyar nyelv szlovákiai változatainak sajátosságai. Dunaszerdahely: Lilium Aurum.

LANSTYÁK István 2005. Kölcsönszavak a magyar nyelv határon túli változataiban. In: Vörös Ferenc (szerk.) Regionális dialektusok, kisebbségi nyelvhasználat. A 2005. október 20-21-i somorjai konferencia előadásai, Budapest - Nyitra - Somorja: Magyar Nyelvtudományi Társaság Konstantin Egyetem Közép-európai Tanulmányok Kara-Fórum Kisebbségkutató Intézet - Lilium Aurum. 21-26.

LANSTYÁK István 2006. A kölcsönszavak rendszerezéséről. In: Uő. Nyelvböl nyelvbe. Tanulmányok a szókölcsönzésról, kódváltásról és forditásról. Pozsony: Kalligram. 15-56.

LANSTYÁK István 2009a A platni botrány. (Egy új stílusminősítési rendszer felé). Fórum. Társadalomtudományi Szemle. 2. sz. 25-41.

LANSTYÁK István 2009b. A határon túli magyar szókészlet eredet szerinti rétegei. LANSTYÁK István - Menyhárt József - Szabómihály Gizella (szerk.) Tanulmányok a kétnyelvúségröl IV. Dunaszerdahely: Gramma. 78-115.

MÁRTON Gyula 1958. Perechi de cuvinte în graiul ceangău din Moldova. In Alexandru Rosetti (red.): Omagiu lui Iorgu Iordan cu priljul împlinirii a 70 de ani. București: Editura Academiei R.P.R. 557-69 
MÁRTON Gyula 1959. Eredményeink és feladataink a magyar nyelvet ért román hatás tanulmányozásának terén. Studia Universitas Babeș-Bolyai 2: 29-41.

MÁRTON Gyula 1960. Schimbări semantice petrecute în graiul ceangăilor din Moldova sub influența limbii române. Studii și Cercetări Lingvistice XI. 917-926.

MÁRTON Gyula 1972. A moldvai csángó nyelvjárás román kölcsönszavai. Bukarest: Kriterion Könyvkiadó.

MÁRTON Gyula - PÉNTEK János - VÖÖ István 1977. A magyar nyelvjárások román kölcsönszavai. Bukarest: Kriterion Könyvkiadó.

MELICH János 1933. A jövevényszavak átvételének módjáról. Magyar Nyelv XXIX. 1-11.

MMCSA 2009. A mai magyar családnevek adatbázisa. Elektronikusan tárolt adatbázis. Kutatásvezető: Vörös Ferenc.

MUNKÁCSI Bernát 1880-81. A moldvai csángók nyelvjárása. I-VI. Magyar Nyelvör IX. 10. 444-455., 11. 481-493., 12. 529-533., X. 3. 101-107., 4. 149-158., 5. 199-205.

MURÁDIN László 1960. Román nyelvi hatás az aranyosszéki magyar nyelvjárás szókészletében. Nyelv-és Irodalomtudományi Közlemények IV. 129-35.

MURÁDIN László 1979. Jövevényszók a mérlegen. Korunk 7-8: 612-7.

MURÁDIN László 2005. Erdélyi magyar családnevek. Nagyvárad: Europrint Kiadó.

O. NAGY Gábor 1988. Mi fán terem? Budapest: Gondolat Kiadó.

NEMESI Attila L. 2000. A természetesen, hogy ... típusú szintaktikai szerkezetekről. Magyar Nyelvór 124. 430-442.

NICULESCU, Alexandru 2005. „Romania Hungarica” - contacte lingvistice și culturale româno-maghiare. Studia Universitas Petru Maior. Series Philologia. 18-35.

NYOMÁRKAY István 2003. Magyar és német szavak a burgenlandi horvát nyelvben. In: Hajdú Mihály és Keszler Borbála (szerk.) Köszöntő könyv Kiss Jenő 60. születésnapjára. Budapest: ELTE Magyar Nyelvtudományi és Finnugor Intézete. 94-100.

NYOMÁRKAY István 2004. Nyelvi kölcsönhatás a szavak tükrében. (A magyar-horvát nyelvi kapcsolatok múltja és jelene) http://www.mta.hu/ fileadmin/szekfoglalok/000853.pdf [2013]

PÉNTEK János 1988. Teremtô nyelv. Bukarest: Kriterion Könyvkiadó. 
PÉNTEK János 1993. Magyar nyelvi gondok Romániában. Magyar Nyelvốr 4: 482-5. 1.

PÉNTEK János 1994. Az anyanyelv ökológiája Erdélyben. Kétnyelvüség 1 sz. 8-16.

PÉNTEK János 1996. A magyar-román interetnikus kapcsolatok néhány nyelvi vonatkozása. In: Katona Judit - Viga Gyula (szerk.) Az interetnikus kapcsolatok kutatásának újabb eredményei. Miskolc: Hermann Ottó Múzeum. 113-120.

PÉNTEK János 1999. Az anyanyelv mítosza és valósága. Kolozsvár: Anyanyelvápolók Erdélyi Szövetsége.

PÉNTEK János 2001. A nyelv ritkuló légköre. Kolozsvár: Komp-Press, Korunk Baráti Társaság.

PÉNTEK János 2006. Néhány (utólagos) észrevétel a nyelvek érintkezéséről. In: Vass László (szerk.) A mondat: kaland. Szeged: SZEK Juhász Gyula Felsőoktatási Kiadó. 301-304.

PÉNTEK János 2007. Transzszilvanizmusok, romanizmusok és a határtalanítás programja. Maticsák Sándor - Jankovics József- Kolláth Anna - Nyerges Judit- Péntek János (szerk.) Nyelv, nemzet, identitás. I. kötet. Debrecen-Budapest: Nemzetközi Magyarságtudományi Társaság. 115-124.

PÉNTEK János 2008. A magyar nyelv erdélyi helyzete és perspektívái. Fedinec Csilla (szerk.) Ertékek, dimenziók a magyarságkutatásban. Budapest: Magyar Tudományos Akadémia, Magyar Tudományosság Külföldön Elnöki Bizottság.136-152.

PÉNTEK János 2010. Változatok és változások a mai magyar nyelvben. Magyar Nyelv 1 sz. 14-23.

PÉNTEK János - BENŐ Attila 2003a. Nyelvi jogok Romániában. Nádor Orsolya - Szarka László (szerk.) Nyelvi jogok, kisebbségek, nyelvpolitika Kelet-Közép-Európában. Budapest: Akadémiai Kiadó. 123-145.

PÉNTEK János - BENŐ Attila 2003b. Nyelvi kapcsolatok, nyelvi dominanciák az erdélyi régióban. Szabó T. Attila Nyelvi Intézet Kiadványai 1. Kolozsvár: Anyanyelvápolók Erdélyi Szövetsége.

PÉNTEK János - BENŐ Attila (szerk.) 2005. Nyelvi jogi környezet és nyelvhasználat. Szabó T. Attila Nyelvi Intézet Kiadványai 2. Kolozsvár: Anyanyelvápolók Erdélyi Szövetsége.

PÉTER Mihály 1984. Érzelemkifejezés, stílusérték és expresszivitás a nyelvben. Általános Nyelvészeti Tanulmányok XIV. 219-35. 
POSGAY Ildikó 2000. The Syntactic Construction of the Type (el) kell menjek in Standard Hungarian and the Influence of Transylvanian Dialects. Dialectologia et geolinguistica. 63-67.

RÁCZ Anita 2007. A régi Bihar vármegye településneveinek történeti-etimológiai szótára. Debrecen: Debreceni Egyetem, Magyar Nyelvtudományi Tanszék.

RÁCZ Endre 1992. A belehallás jelenségéról. Budapest: Akadémiai Kiadó.

REUTER Camillo 1985. Kegyeri és Kudzsir. Magyar Nyelv 81. 469-75.

ROT Sándor 1972. A nyelvi kontaktusok kérdéséről. Nyelvtudományi Közlemények. 1. 49-69.

SALA, Marius 1997. Limbi în contact. București: Editura Enciclopedică.

SÁNDOR Klára 1998. Amiért a szinkrón elemzés foszladozik. In: Sándor Klára (szerk.) Nyelvi változó - nyelvi változás. Szeged: Juhász Gyula Felsőoktatási Kiadó. 57-84.

SKUTNABB-KANGAS, Tove 1997. Nyelv, oktatás és a kisebbségek. Budapest: Teleki László Alapítvány.

SORBÁN Angella 2000 „Tanuljon románul a gyermek, hogy jobban érvényesülhessen." Az asszimiláció természetrajzához. Magyar Kisebbség, 1. sz. 167-180.

SORBÁN Angella 2011. Kisebbség és kétnyelvüség. A kétnyelvüség szociológiai aspektusai az oktatásban és a munkaerópiacon. PhD-dolgozat (Kézirat).

SZABÓ T. Attila 1960a. A Pápai Páriz szótárkiadások magyar szókincsének román kölcsönszó-anyaga. Studia Universitatis Babes-Bolyai 2. sz. 15-28.

SZABÓ T. Attila 1960b. Román kölcsönszavaink Gyarmathi Sámuel nyelvhasonlításában. Nyelv-és Irodalomtudományi Közlemények IV. 297-315.

SZABÓ T. Attila 1962. Eredmények és hiányosságok a magyar szókincs román eredetű feudalizmuskori elemeinek vizsgálatában. Studia Universitatis Babes-Bolyai I. 19-34.

SZABÓ T. Attila 1967. Kniezsa István szerepe a magyar szókincs román eredetű elemeinek vizsgálatában. Nyelv-és Irodalomtudományi Közlemények I.: $149-155$.

SZABÓ Zoltán 1965a. Román eredetű elemek Barcsay Ábrahám költői nyelvében. Nyelv-és Irodalomtudományi Közlemények IX. 1. sz. 149-155.

SZABÓ Zoltán 1965b A Gyöngyösi Latin-magyar szótártöredék román eredetű szavai. Nyelv-és Irodalomtudományi Közlemények IX. 2. sz. 293295. 
SZARVAS Gábor 1874. A moldvai csángó nyelvről. Magyar Nyelvőr III. 1: 1-6; 2: 49-54.

SZÉKELY Győző - NAGY Arisztid 2009. Román-magyar földrajzszótár. Kolozsvár: Ábel Kiadó.

SZILÁGYI N. Sándor 1996. Hogyan teremtsünk világot? Rávezetés a nyelvi világ vizsgálatára. Kolozsvár: Erdélyi Tankönyvtanács.

SZILÁGYI N. Sándor 2005. Asszimilációs folyamatok a romániai magyarság körében. In: Péntek János - Benő Attila (szerk.) Nyelvi jogi környezet és nyelvhasználat. A Szabó T. Attila Nyelvi Intézet Kiadványai 2. Kolozsvár: Anyanyelvápolók Erdélyi Szövetsége. 24-94.

SZILÁGYI N. Sándor 2007. Szociálpszichológiai tényezők a szókölcsönzésben. In: Benő Attila - Fazakas Emese - Szilágyi N. Sándor (szerk.) Nyelvek és nyelvoáltozatok. Kolozsvár: Anyanyelvápolók Erdélyi Szövetsége, II. 349-361.

SZILÁGYI N. Sándor 2008. A magyar nyelv a Magyarországgal szomszédos országokban. In: Fedinec Csilla (szerk.) 2008. Értékek, dimenziók a magyarságkutatásban. Budapest: Magyar Tudományosság Külföldön Elnöki Bizottság. 105-118.

SZINNYEI József 1895. A magyar nyelvbe átvett oláh szavak. Magyar Nyelvör. XXII, 23 kk, XIII, 5 kk.

SZŐCS Tünde-Arabella 2012. A közössééi oldalokon használt csett-nyelv jellegzetességei. (Mesteri szakdolgozat. Kézirat.)

TAMÁS Lajos 1966. Etymologisch-historisches Wörterbuch der ungarischen Elemente im Rumänischen. Budapest: Akadémiai Kiadó,

THOMASON, Sarah, G. 2001a. Language Contact. Washington D. C: Georgetown University Press.

THOMASON, Sarah, G. 2001b. Can Rules Be Borrowed? http://www-personal.umich.edu/ thomason/papers/ruleborr.pdf [2010]

TOLCSVAI Nagy Gábor 2007. Idegen szavak szótára. Budapest: Osiris Kiadó.

TÓTFALUSI István 2008. Idegenszó-tár. Budapest: Tinta Könyvkiadó.

VAS József 1863. Kapnikbánya s vidékének nyelvjárása. Nyelvtudományi Közlemények 2. sz. 362-80.

VERES Valér 2007. Az erdélyi magyarok demográfiai képe az ezredforduló után, a 2002-es népszámlálási adatok tükrében. Kolozsvár: Max Weber Társadalomkutató Alapítvány.

VESZELSZKI Ágnes 2013. A digilektus hatása az írásbeli és a szóbeli kommunikációra egy kérdőíves vizsgálat alapján. Magyar Nyelvőr 3. sz. 248-274 
VICSAI Judit 2007. Interferencia-jelenségek a magyar anyanyelvü tanulók nyelvhasználatában. I. fokozati tanári szakdolgozat. (Kézirat). Témavezető: Benő Attila.

WARDHAUGH, Ronald 2002. Szociolingvisztika. Budapest: Osiris Kiadó.

WEINREICH, Uriel 1953. Languages in Contact. Findings and Problems. New York: Publications of the Linguistic Circle of New York. Nr. 1.

WICHMANN, Yrjö 1936. Wörterbuch des Ungarischen Moldauer Nord-csángó und des Hétfaluer Csángódialekts nebst grammatikalischen Aufzeichnungen und Texten aus dem Nordcsángódialekt. Hereausgegeben von Bálint Csüri und Arturi Kannisto. Helsinki: Lexica Societatis Fenno-Ugricae.

ZAFIU, Rodica 2007. Ninjalău. România Literară. nr. 27.

ZAICZ Gábor 2006. Etimológiai szótár. Budapest: Tinta Könyvkiadó.

ZSEMLYEI János 1969. Román kölcsönszavaink -uj szóvégének kérdéséhez. Nyelv-és Irodalomtudományi Közlemények XII. 117-21.

ZSEMLYEI János 1979. A Kis-Szamos vidéki magyar tájszólás román kölcsönszavai. Bukarest: Kriterion Könyvkiadó.

ZSEMLYEI János 1995a. Román tükörszavak, tükörkifejezések és hibridszavak a romániai magyarság nyelvhasználatában. In: Kassai Ilona (szerk.): Kétnyelvúség és magyar nyelvhasználat. Budapest: MTA Nyelvtudományi Intézet. 245-252.

ZSEMLYEI János 1995b. Román köznevek magyar családnévvé válása az erdélyi régiségben. In: B. Gergely Piroska - Hajdú Mihály (szerk.) AzV. Magyar Névtudományi Konferencia elóadásai. Budapest-Miskolc: Magyar Nyelvtudományi Társaság - Miskolci Egyetem Bölcsészettudományi Intézete. 108-112. 


\section{TÁRGYMUTATÓ}

alaki kölcsönszó 41, 54, 75, 77

alakváltozat 93, 120

alapjelentés 62, 112

államnyelv 21, 22, 26, 29, 37

általános alany 126

analitikus szerkezet $17,47,87,126$

analógia 75, 100, 135

analóg képző 69, 109

analóg morféma 69

angol nyelv 36, 38, 57, 75, 101, 127

asszimiláció 26,31

átadó nyelv 36, 135

attitüd 26

belehallás $69,95,96,97$

betüszókölcsönzés 42, 73

bizalmas 58, 60, 112

családnév 66, 67, 69, 71, 73

demográfiai tényező 22 , 23, 25

diákszleng 57

direkt kölcsönzés 39, 40, 43, 49, 51

diszkrimináció 27

dominancia 22 ellipszis 130, 131, 136

elöljáró 76, 108, 126

értékjelentés 19, 105, 135

etnocentrikus szemlélet 19

eufemisztikus 60

expresszivitás 11

fatikus elem 18

fónév 57, 80, 83, 88, 99, 106, 107, 116

földrajzi név 63, 64

frazémakölcsönzés 45, 46, 82

grammatikalizáció 95, 101

gúnyos 74

gyakoriság 38, 102, 124, 125, 135

hangalaki expresszivitás 61, 134

hangalakkölcsönzés 42, 54, 55, 75

hangszerkezet 38,40

hangutánzó szó 61

hapax legomenon 18

helységnév 29

hibridkölcsönszó 49, 92, 135

hibridkölcsönzés 39

hibridszerkezet 49, 85, 79, 91, 93, 135

hibridszó 91

hiperkorrekció 77 
hiperpurizmus 44

hivatali nyelv 12, 133, 135

honosító képző 68

idegen nyelv 27, 36

idegen szó $13,22,37,38,42,43,54,59$

identitás 25,27

igazságszolgáltatás 22, 27, 134

igekötő 45, 101, 104, 105

indirekt kölcsönzés 9, 39, 47, 49, 59, $66,79,82,135$

interferencia $13,17,34$

ironikus 60,74

jelentésbeli expresszivitás 16

jelentésbesugárzás 103, 112

jelentésgyarapodás 116

jelentéskölcsönzés 44, 79, 117

jelentésmódosulás 14, 39, 43, 44, 97, 112,118

jelentésspecializálódás 103, 104, 105

jelentésszűkülés $13,15,113,114$

jelentésváltozás 15, 16, 61, 78, 96, 136

jelkölcsönzés 34

jövevényszó 38

jövevényszólás 45

káromkodás 18

kategorizáció 18, 39, 134

katonai szleng 57

képző 36, 103, 106, 108, 109

képzőcsere 107, 108, 109

keresztnév 73

kétnyelvség 18

kicsinyítő képző 48, 99, 100

kodifikáció 26

kódváltás 39

kölcsönhomonima 77

konnotatív jelentés 60

kontaktusváltozat 42, 124

korpusztervezés 19 közigazgatás 16

különfejlődés 111

másodlagos kölcsönszó 41, 65, 104, 106, 107

másodnyelvdomináns 54

meghonosodás $15,34,69,76,77,78$, 93, 95, 106, 108

megőrzött régiség 87, 88, 89, 135

melléknév 57, 79, 83, 93, 105, 106, 109

metafora 19, 62

metaforikus jelentésátvétel 62

metaforikus jelentésmező 62

morféma 13, 96, 97, 101, 106, 108, 135

morfémacsere 106

morfémakölcsönzés 43

morfémikus átvétel 39

motiváltság 16, 96, 99, 104

nemzetközi szó 38, 42, 45

népetimológia 13, 16, 61, 96

névátvitel 19

névvariáns 69

nyelvcsere 31

nyelvi bizonytalanság 48

nyelvi hiány 24, 39

nyelvi jog 19, 21

nyelvi kompetencia 22

nyelvi presztízs 25, 26

nyelvismeret 22

nyelvi státus 27

nyelvi tervezés 31

nyelvi univerzálé 33

nyelvpolitika 26,134

nyelvváltozat $9,51,55,57,59,67,75$,

$81,82,87,89,91,107,111,112$,

$113,120,121,133,136$

nyelvvesztés 24

oktatás 22, 24, 25, 26, 28

onomatopoézis 18 
összetett szó 45, 65, 98, 108

pejoratív 57, 60, 100, 119

pejoratív jelentésváltozás 19,57

poliszémia $79,115,120$

pragmatikai jelenség 18

predikatív szerkezet 48, 127, 128

produktivitás 95, 101, 102, 104, 96

redundáns névmás 48

regionális köznyelv 16, 53, 54, 112, 114

regiszter $21,24,40,41,51,52,56,57$, $58,59,82,83,91,108,119,133$

relatív kontaktusjelenség 47, 87, 124, 128

romándomináns 57, 82, 93

sajtónyelv 13, 53, 56

segédige 124,127

standard nyelvváltozat $15,41,42,46$, $48,60,75,86,91,108,124,126$, 129

stílusérték 39, 46, 54, 89, 112

stíluskölcsönzés 43, 46

stílusminősítés 52, 59

stílusváltozat 51, 58

szaknyelv 16, 133

számbeli egyeztetés 48,128

származékjelentés 19, 80, 81, 112

személynév 65, 66, 69

szenvedő szerkezet 127, 128

szinonímia 15, 60, 104

szleng 55, 56, 57

szóelvonás 96, 98

szórend 17, 34, 123, 124

szórvány 28, 31, 124, 133

tagmondat 123, 130

társadalmi státus 24

társadalomszerkezet 24 toldalék $36,42,98,126$

tükörfordítás $45,49,82,84$

tükörkifejezés $45,81,85,87$

tükörszerkezet 79, 81, 82, 123, 135

tükörszó 44, 81

tulajdonnév 68

tulajdonnév-kölcsönzés 41, 134

vándorszólás 45

visszakölcsönzés 43, 65, 66, 68, 75

vonzatkölcsönzés 125, 126 

REZUMAT

\section{FENOMENE CONTACTOLOGICE ÎN LIMBA MAGHIARĂ DIN TRANSILVANIA}

Cartea de față este cea mai nouă contribuție cu caracter monografic a fenomenelor contactologice și sociolingvistice în dialectul transilvăneană a limbii maghiare. Ea reprezintă o sinteză a cercetărilor de mai multe decenii în domeniu, la care însă sunt adăugate noi informații în descrierea proceselor contactologice directe și indirecte pe baza cercetărilor empirice recente. Se pune un accent în mod deosebit asupra procesului integrării lexicale a cuvintelor și locuțiunilor lexicale împrumutate. Influența lingvistică pe care limba română, ca limbă de stat o are asupra limbii maghiare din Transilvania este analizată în detaliu din punct de vedere structural, la diferite nivele ale limbii de la morfologie pînă la sintaxă. Iar influența limbii engleză ca limbă de circulație mondială este de asemenea evaluată în mai multe capitole.

Sursele lexicale ale cercetării sunt atât dicționarele consacrate privind lexicul limbii maghiare ca A magyar nyelvjárások román kölcsönszavai (Cuvinte de împrumut de origine română în dialectele limbii maghiare) redactat de Márton Gyula, Péntek János și Vöő István, cât și baze de date lexicografice recente (Dicționarul online Termini). Fenomenele prezentate se bazează și pe constatările din recentele cercetări cuprinse în disertațiile masterale și lucrările de doctorat scrise despre anumite aspecte ale acestei probleme. În privința proceselor sociolingvistice în descrierea fenomenului studiat, s-a ținut seama și de rezultatele unei cercetări efectuată în 2009 de Institutul de Studierea Problemelor Minorităților Naționale pe un eșantion reprezentativ.

Prezentarea fenomenelor de împrumut la nivel lexical nu neglijează nici cuvintele proprii, cum sunt nume geografice și nume de familie. Aceste influențe lingvistice la nivelul numelor proprii sunt prezentate atât din punct de vedere diacronic cât și sincronic folosind baza de date electronice noi, ca A mai magyar családnevek adatbázisa (Baza de date a numelor de familie contemporane maghiare) redactat de dr. Vörös Ferenc.

Constatările și concluziile lucrării pot fi valorificate în descrierea limbii maghiare contemporane și în procese de planificare a limbii în condiții de minoritate. 



\section{ABSTRACT}

\section{LANGUAGE CONTACT ISSUES IN THE HUNGARIAN SPOKEN IN TRANSYLVANIA}

The book is a monograph on the sociolinguistic and contactological phenomena in the Hungarian language variants used in Transylvania (Romania). The work integrates the previous researches in the field and shows the new results of direct and indirect contact processes analysis based on recent empirical surveys. The means of foreign words' integration and phrases are particularly emphasized. Romanian, as a state language, has a considerable effect on the Hungarian language variants in Transylvania. This process is structurally analyzed at different levels from morphology to syntax. The influence of English on Hungarian is also discussed in several chapters.

The lexical and lexicographic sources for the research are the recognized dictionaries for Hungarian (for example: A magyar nyelvjárások román kölcsönszavai [Lexical Borrowings of Romanian Origin in Hungarian Dialects]) and recent lexical databases (Termini Online Dictionary). The description of the contactological processes also uses the findings of recent MA and PhD dissertations written at Hungarian Linguistic Department (Babes-Bolyai University, Cluj/Kolozsvár). The sociolinguistic observations also make use of the representative survey conducted by the Institute for National Minorities Studies (Cluj / Kolozsvár) in 2009.

The description of lexical borrowings also covers proper names, such as surnames and toponyms. The borrowings of proper names are presented both from diachronic and synchronic approach, making use of the new database as the Database of Hungarian Surnames (ed. Vörös Ferenc).

The book's observations and conclusions can be useful both in the description of present-day Hungarian as well as in the language's planning and policy. 

A nyelvi érintkezések nem légüres térben zajlanak, hanem földrajzilag és időben meghatározható módon, kulturális és szociális kontextusban érintkező konkrét nyelvi közösségek és nyelvváltozatok szintjén. Ha a nyelvi kontaktusfolyamatok miértjeire kívánunk válaszolni, akkor mindenképpen szem előtt kell tartanunk az adott kétnyelvűség vagy többnyelvưség típusát, annak folyamatát meghatározó gazdasági, szociális és kulturális tényezőket. Jól szemlélteti ezt az összefüggést a konkrét kontaktusfolyamatok és a társadalmi-gazdasági tényezők között az erdélyi magyar nyelvváltozat különböző regisztereiben használt román (és kisebb mértékben angol) eredetű közvetlen és közvetett lexikai átvételek kérdése.

ISBN 978-606-739-004-9

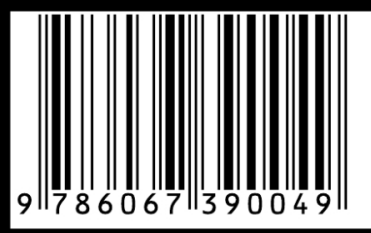

